Universidade de São Paulo

Escola de Comunicações e Artes

Cristina Pontes Bonfiglioli

\title{
Discurso ecológico: a palavra e a fotografia no Protocolo de Kyoto
}




\section{Cristina Pontes Bonfiglioli}

\section{Discurso ecológico: a palavra e a fotografia no Protocolo de Kyoto}

Tese apresentada ao Programa de Pós-Graduação em Ciências da Comunicação, Área de Concentração Estudo dos Meios e da Produção Midiática, da Escola de Comunicações e Artes da Universidade de São Paulo, como exigência parcial para obtenção do título de Doutora em Ciências da Comunicação, sob orientação da Profa. Dra. Maria do Socorro Nóbrega.

São Paulo

Maio/2008 
AUTORIZO A REPRODUÇÃO E DIVULGAÇÃO TOTAL OU PARCIAL DESTE TRABALHO, POR QUALQUER MEIO CONVENCIONAL OU ELETRÔNICO, PARA FINS DE ESTUDO E PESQUISA, DESDE QUE CITADA A FONTE.

Ficha Catalográfica

Serviço de Biblioteca

Escola de Comunicações e Artes

Universidade de São Paulo

Bonfiglioli, Cristina Pontes

Discurso ecológico: a palavra e a fotografia no Protocolo de Kyoto / Cristina Pontes Bonfiglioli. - São Paulo : Cristina Pontes Bonfiglioli, 2008.

169 p. : il.

Tese (Doutorado) - Departamento de Jornalismo e Editoração / Escola de Comunicações e Artes/USP, 09/05/2008.

Orientadora: Prof. Dra. Maria do Socorro Nóbrega.

Bibliografia

1. Comunicação - Discurso Ecológico - Séculos 19, 20, 21

2. Comunicação - Fotografia - Séculos 19, 20, 21

3. Fotojornalismo I. Nóbrega, Maria do Socorro II. Título.

CDD 21.ed. - 302.2 


\section{FOLHA DE APROVAÇÃO}

Cristina Pontes Bonfiglioli

Discurso ecológico: a palavra e a fotografia no Protocolo de Kyoto

Tese apresentada ao Programa de Pós-Graduação em Ciências da Comunicação, Área de Concentração Estudo dos Meios e da Produção Midiática, da Escola de Comunicações e Artes da Universidade de São Paulo, como exigência parcial para obtenção do título de Doutora em Ciências da Comunicação, sob orientação da Profa. Dra. Maria do Socorro Nóbrega.

Aprovado em:

Banca Examinadora

Profa. Dra. Maria do Socorro Nóbrega

Instituição: ECA-USP (CJE) Assinatura:

Prof. Dr. Norval Baitello Jr.

Instituição: PUC-SP Assinatura:

Profa. Dra. Eda Teresinha de Oliveira Tassara

Instituição: IP-USP Assinatura:

Profa. Dra. Dulcilia Helena Schroeder Buitoni

Instituição: ECA-USP (CJE) Assinatura:

Profa. Dra. Marilia Pacheco Fiorillo

Instituição: ECA-USP (CJE) Assinatura: 


\section{:: Dedico ::}

Ao Mateus, que no seu encontro violento com a racionalidade do mundo, aos três anos de idade, compreendeu e tranqüilamente enunciou: "Eu moro no meu quarto, meu pai mora no trabalho e minha mãe mora no computador."

Ao Sandro, porque ambos sofremos igualmente de ataques constantes do pequeno monstro caseiro Okupa Derrimus ${ }^{1}$, famoso por deixar pais sem tempo para se divertir.

À Carmen Lúcia e ao Arnaldo, que, obstinadamente, têm apoiado as minhas escolhas, independente de as compreenderem ou delas discordarem. É sempre bom poder contar com alguns poucos fãs fiéis e fanáticos assim!

${ }^{1}$ Conheça-o melhor em Mais um pequeno manual sobre monstros caseiros, de Stanislav Marijanovic (Companhia das Letrinhas, 2001) 


\section{:: Agradecimentos ::}

À Professora Maria do Socorro, pela sinceridade com que auxiliou o desenvolvimento deste trabalho.

À CAPES, pela Bolsa de Doutorado concedida durante 36 meses, sem a qual a dedicação a esta pesquisa não teria sido possivel.

Aos amigos que fiz neste percurso, desde meu primeiro contato com a ECA, como aluna especial, até o término deste doutorado, e que, em momentos distintos, tiveram a generosidade de se fazer presentes para ouvir minhas dúvidas e de se esmerar na criatividade para sugerir soluções: Cíntia Liesenberg, Valmir Costa, Edna Melo, Eduardo Furtado Leite, Regina Azevedo, Tarcísio D’Almeida, Sônia Oliveira, Mariana Duccini, Ricardo Orlando, Juliana Oliveira, Mariana Joffily, Andréa Tavares, Gisa Bustamante Bonnemaison, Patrícia De Rossi, Sergio Correa Vaz, , Ana Célia Martinez, Fabio Carmaneiro, Jorge Miklos.

À virtual Trupe Metaporos, nomeadamente, Danielle Naves, Marco Toledo, Paulo Masella, Ana Elisa Viviani, Tarcyanie Cajueiro que, feito um Sancho Pança imaginário, ensinou-me a enfrentar minhas idiossincrasias.

Aos professores Jeanne Marie Machado de Freitas, Rosana de Lima Soares, José Guilherme Cantor Magnani, Sergio França Adorno de Abreu, Helena Nagamine Brandão, Eda Tassara, Ciro Marcondes Filho, Dulcília Buitoni, Norval Baitello, Rose de Melo Rocha pelos encontros, - únicos ou esporádicos; breves ou mais duradouros -, que foram extremamente úteis na definição de rumos e reavaliação constante do desenvolvimento deste trabalho.

Ao Paulo César Bontempi, Tânia Magaly Aníbal, Elaine Pereira, Miriam Zarati e Roseli Vieira que, com gentileza e paciência, foram responsáveis por me conduzir, com tranqüilidade, pelas mais diversas etapas burocráticas necessárias à conclusão deste doutorado.

À Claudia Kohler, Silvia Melcher, Maria Rita Avanzi, Bel Garcia, Fernando Portella, Maria Cecília Brosso, Valéria D’Amico, Roberto Kishinami pela amizade que insiste, apesar da correria da vida, e pela disponibilidade para almoços, cafés, emails, telefonemas ou chats, toda vez que me desesperei.

À Jô, Su, Rica, Giu, Márcia, Fausta e Romolo, por garantir porto-seguro ao Mateus quando minha ausência se fez necessária.

À Margô e à Celina, cuja paixão e estímulo pela sensibilidade da Arte tiveram papel crucial para ampliar as possibilidades desta pesquisa. Uma pesquisa é feita de fatos, mas também de possibilidades. 


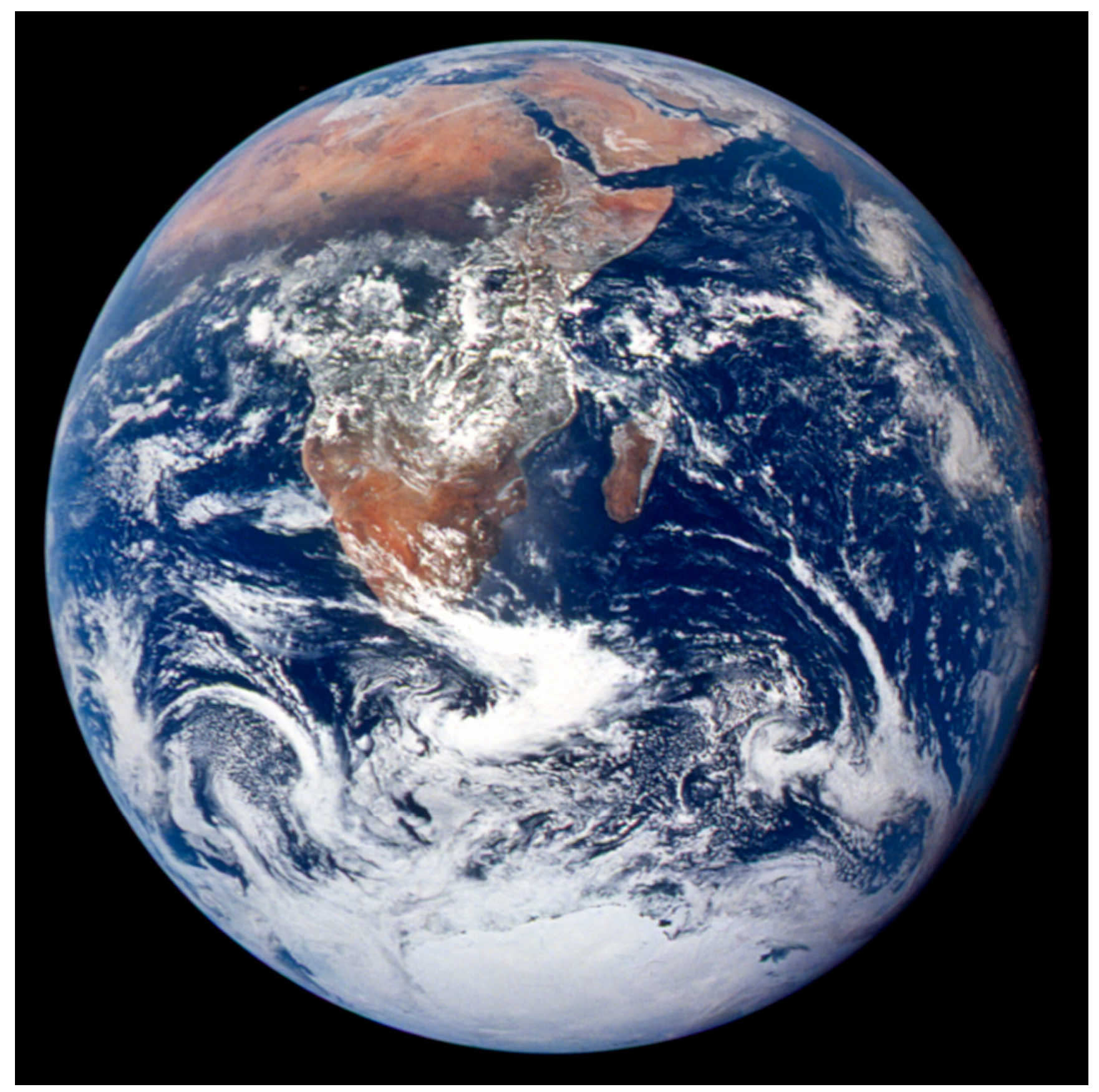




\section{Legenda ${ }^{2}$ :}

This classic photograph of the Earth was taken on December 7, 1972. The original caption is reprinted below:

View of the Earth as seen by the Apollo 17 crew traveling toward the moon. This translunar coast photograph extends from the Mediterranean Sea area to the Antarctica south polar ice cap. This is the first time the Apollo trajectory made it possible to photograph the south polar ice cap. Note the heary cloud cover in the Southern Hemisphere. Almost the entire coastline of Africa is clearly visible. The Arabian Peninsula can be seen at the northeastern edge of Africa. The large island off the coast of Africa is the Malagasy Republic. The Asian mainland is on the horizon toward the northeast.

\footnotetext{
${ }^{2}$ Disponível em: http://earthobservatory.nasa.gov/Newsroom/BlueMarble/BlueMarble history.html Acesso em: 12 Out. 2007.
} 
A Terra é azul! Yuri Gagarin, cosmonauta russo. (1961)

Quando, na manhã do dia de Natal, pudemos olhar em direção ao planeta que é a nossa casa, a boa Terra pareceu-nos pequenina e linda, um oásis de vida na desolada solidão do espaço. Frank Frederick Borman, comandante da Apollo 8. (1968)

Quando a Terra é avistada da Lua, não são visíveis nela divisões em nações ou Estados. Isso pode ser o simbolo da mitologia futura. Essa é a nação que iremos celebrar, essas são as pessoas às quais nos uniremos. Joseph John Campbell (1988) 


\section{:: Resumo ::}

BONFIGLIOLI, Cristina Pontes. Discurso ecológico: a palavra e a fotografia no Protocolo de Kyoto. 2008. 169 fls. Tese (Doutorado) - Escola de Comunicações e Artes, Universidade de São Paulo. 2008.

Esta pesquisa teve como objetivo relacionar operações discursivas distintas - a palavra e a imagem - a partir de um recorte também duplo, o discurso ecológico constituido pelo Protocolo de Kyoto e as fotografias que se auto-designam como representações imagéticas do mesmo. O trabalho elabora relações, aproximando e diferenciando conceitos como formação discursiva e enunciação de Foucault; escritura, de Derrida; representação, de Heidegger; gesto fotográfico, de Flusser, e ato fotográfico, de Dubois, Sensação, de Deleuze, além de incluir as abordagens teóricas sobre a fotografia de paisagem, de Krauss e considerações sobre a natureza e a história da fotografia, de Fabris. A partir da convenção que define que toda fotografia é permeada por texto ou por formações discursivas, propôs-se a análise de grupos de imagens fotográficas desvinculadas de seus textos de origem, mas às quais se atribui o papel de "ilustração" do Protocolo de Kyoto. O resultado mostra que há fotografias produzidas como cópias estereotipadas da significação que seus textos de origem thes impõem e há outras que conseguem desvincular-se deles, apresentando-se ao observador como fruição e Sensação. O Protocolo de Kyoto é representado pelos textos e formações discursivas que o organizam e o instituem, mas não por todas as imagens fotográficas que lhe são associadas. Tais fotografias expressam maior autonomia em relação aos seus contextos de origem porque seus elementos estéticos são vetores de força mais intensa que a escritura cientifica que legitima o valor de verdade do Protocolo.

Palavras-chave: 1. discurso ecológico, 2. gesto fotográfico, 3. ato fotográfico, 4. representação, 5. imagemsensação 


\section{:: Abstract ::}

BONFIGLIOLI, Cristina Pontes. Ecological discourse: writing and photography in the Kyoto Protocol. 2008. 169 fls. Thesis (Doctorate) - Escola de Comunicações e Artes, Universidade de São Paulo. 2008.

This research intended to relate distinct discursive operations considered as the opposition between writing and image, based in another opposition, the ecological speech, constituted by the Kyoto Protocol and the photographs that are assigned as "representations" to illustrate it. The analysis elaborates relations, by approaching and differentiating concepts such as discursive formation and enunciation in Foucault; scripture and writing, in Derrida; representation, in Heidegger; in Flusser, and photographic act, in Dubois, Sensation, in Deleuze, beyond including the theoretical approaches on the photograph of landscape, by Krauss and considerations about the nature and the history of the photograph, by Fabris. From the convention that defines that all photography is permeated by text or surrounded by discursive formations, the approach proposed the analysis of groups of photographic images freed from their texts of origin, but to which the role of "illustration" of the Protocol of Kyoto is attributed. The result shows that there are photographs produced as stereotyped copies of the significance that their texts of origin impose to them and there are other photographs which seem to be detached from texts, presenting themselves to the observer as fruition and Sensation. The Protocol of Kyoto is represented by the texts and discursive formations that organize and institutionalize it, but not by all the photographic images that are associated to it. Such photographs express bigger autonomy regarding their contexts of origin because their aesthetic elements are vectors of more intensive force than the scientific writing, which legitimizes the value of truth of the Protocol.

Keywords: 1. ecologycal discourse, 2. photographic gesture, 3. photographic act, 4. representation, 5. Sensation-images 


\section{:: Sumário ::}

:: Introdução ::

Capítulo 1 :: Pensamento ecológico e imagem do mundo ::

1 :: A relação Homem-Natureza: o mítico e a ruptura incompleta ::

2 :: Escritura e a concepção de unidade da Natureza :: 32

3 :: Formação discursiva e o pensamento ecológico contemporâneo :: 43

:: Referências Bibliográficas :: 64

Capítulo 2 :: A fotografia sobre meio ambiente ::

$1::$ Imagem, texto e representação :: 67

$2::$ Fotografia, paisagem e fotojornalismo :: 74

3 :: Ato e gesto: camadas distintas da produção do fotográfico :: 85

:: Referências Bibliográficas :: 89

Capítulo 3 :: Gesto fotográfico e o Protocolo de Kyoto ::

$1:$ Kyoto - discurso, texto e escritura :: 90

$2::$ A constituição das Séries sobre Kyoto :: 94

$3::$ As Séries - imagens-informação :: 99

4 :: O "fora" das Séries - imagens-sensação :: 100

$5::$ O gesto fotográfico sobre Kyoto ::

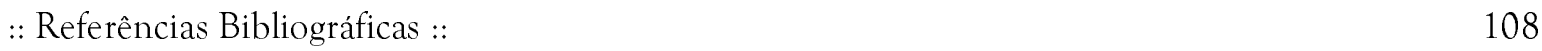

:: Série Tubos :: 109

:: Série Branca :: 113

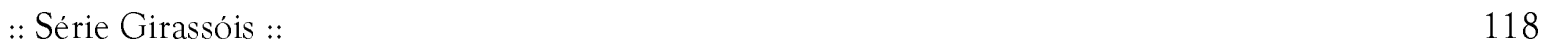

:: Imagens-sensação :: 123

Capítulo 4 :: A representação do Protocolo de Kyoto ::

:: Representação, biopolitica e escritura :: 127

:: Referências Bibliográficas ::

:: Anexo I :: Versão Integral do Protocolo de Kyoto 134

:: Anexo II :: Endereços (URLs) das imagens impressas 164 


\section{:: Introdução ::}

A proposta de pesquisa, inicialmente apresentada tanto à Comissão de Pós-Graduação do Programa de Pós-Graduação em Ciências da Comunicação da ECA-USP quanto à CAPES, para o ano em que entrei no doutorado (2004), tinha como objetivo o estudo do discurso ecológico do ponto de vista da sua divulgação pelo jornalismo e se intitulava Ecologia política e jornalismo impresso: a construção social do discurso ambientalista no Brasil.

O estudo pretendia evidenciar as funções e efeitos da realidade discursiva a que se denomina questão ambiental por meio da sua presença no jornalismo impresso brasileiro. A análise envolvia o levantamento histórico da construção da significação dos vários discursos ecológicos/ambientalistas contemporâneos e o estudo da articulação dos mesmos, - utilizando-se da Análise de Discurso de linha francesa -, pelo jornalismo impresso brasileiro, quando materializa um "falar sobre meio ambiente" em narrativas sobre acidentes ambientais.

Tal análise seria feita por meio da leitura de matérias jornalisticas sobre o acidente de 29 de março de 2003, envolvendo a Indústria Cataguases de Papel Ltda., em Cataguases, Minas Gerais. Porque se tratava de uma leitura "horizontal" dos meios impressos, considerar-se-ia o exercício como a leitura de uma "narrativa". Eram, ao todo, 58 matérias de jornais paulistas, 28 da Folha de São Paulo e 30 do Estado de São Paulo, recuperadas a partir dos websites dos jornais, que tinham sido escolhidos devido à sua grande circulação nacional. As matérias tinham sido publicadas entre $01^{\circ}$ de abril e 28 de maio de 2003, mas existia uma maior concentração delas na primeira quinzena de abril, quando a notícia alcançara grande destaque nas edições diárias de ambos os jornais. A narrativa contava que, no acidente, mais de 20 milhões de litros de resíduos tóxicos vazaram do reservatório de rejeitos industriais da empresa, comprometendo o abastecimento de água de vários municípios do Estado do Rio de Janeiro, prejudicando a pesca e a irrigação e matando animais selvagens e domésticos. $O$ acidente foi considerado pela mídia brasileira "o maior desastre ambiental do país".

O foco da pesquisa era a possibilidade de estudar o funcionamento e os efeitos de sentido da veiculação do discurso ecológico no jornalismo impresso, do ponto de vista lingúístico- 
estrutural, por meio da metodologia da AD francesa, utilizando, principalmente, autores como Pêcheux e Maingueneau.

Porém, com o percurso dos estudos, que incluiram a leitura bibliográfica da área das Ciências da Comunicação, o convívio com as diversas questões temáticas e polêmicas da área, e a participação em disciplinas do programa e de outros programas de Pós-Graduação (como os de Sociologia, de Antropologia e de Lingüística, na FFLCH-USP, e Semiótica da Comunicação, na PUCSP), tornou-se premente revisitar as origens e a motivação da proposta de pesquisa inicial, tendo em vista a minha formação intelectual e profissional, e os meus anseios acadêmicos. $\mathrm{O}$ recorte teórico e metodológico inicial mostrou-se limitado para atender à complexidade do cruzamento entre a temática da sustentabilidade, sua presença na cultura a partir da segunda metade do século XX e o papel dos veículos de informação nesse processo.

Obviamente, toda opção teórico-metodológica traz consigo um conjunto de definições especificas para cada um dos conceitos, o que implica em resultados muito diversos para a abordagem da temática da sustentabilidade pelos midia, enfoque genérico da minha questão cientifica. Por esse motivo, estabeleci uma nova meta de trabalho, impondo-me o objetivo de reestruturar a pesquisa, revisando e alterando o estudo de maneira que atendesse aos meus anseios teóricos e epistemológicos.

Esse esforço de adequação reflete, também, a dificuldade típica de um pesquisador proveniente de outra área do conhecimento, que precisa situar-se na área da Comunicação, tão ampla e rica em contribuições teóricas advindas de disciplinas das Ciências Sociais e Humanas. Decorre, daí, outra dificuldade empírica - a de fazer o recorte teórico-metodológico que pudesse render um trabalho intelectual interessante, superando o maior desafio encontrado: o de abordar a questão ambiental de maneira complexa, inserindo-a na área de Comunicação pela relevância cultural da temática da sustentabilidade.

Foi dessa maneira que surgiu pesquisa sobre as relações entre a palavra e a fotografia como formas de organização do processo comunicativo sobre as Mudanças Climáticas e o Protocolo de Kyoto, investigação que, além de pressupor a complexidade inerente à temática ambiental e ao campo das ciências da comunicação, tem como pano de fundo o cruzamento de diversos 
postulados sobre imagem, escritura, discurso e fotografia, definidos nos estudos de quatro renomados autores: Flusser, Derrida, Foucault e Deleuze.

Assim, a proposta de abordagem da temática ambiental a partir de sua divulgação pela mídia, neste trabalho, considera três aspectos cruciais do processo de circulação da informação, típico do mundo eletrificado contemporâneo: 1) a vinculação da palavra com relações de poder, no que tange à formação discursiva e a vinculação da palavra com operações do pensamento, enquanto escritura; 2) o processo histórico que estabelece a Ecologia como uma prática discursiva cientificamente embasada e politicamente articulada com seus lugares de exercício poder e de saber disciplinares; 3) a notória natureza imagética dos veículos de informação nos séculos 20 e 21, cuja forma de produção faz com que toda imagem seja apresentada acompanhada da palavra (quer seja como discurso, quer seja como escritura cientifica), de maneira a criar atritos com a possibilidade de vivência ou fruição autônoma das imagens.

A pesquisa, ora apresentada, divide-se em quatro capitulos.

No Capitulo 1, com base na leitura de Foucault, introduzido a mim pelo Professor Doutor Sergio Adorno, da FFLCH-USP, e na de Derrida, buscado por mim por pura teimosia, encontra-se o exercício de uma tentativa de pensar a arqueologia ou a genealogia da relação Homem-Natureza tendo em vista sua concepção como imagem mística e como escritura cientifica.

No Capitulo 2, devido às discussões nas aulas da Professora Doutora Dulcília Schroeder (ECAUSP), do Professor Doutor Boris Kossoy (ECA-USP), do Professor Doutor Ciro Marcondes Filho e do Professor Doutor Norval Baitello Jr. (PUC-SP), bem como a leitura de Rosalind Krauss, Annateresa Fabris e Vilém Flusser, tentei realizar o mesmo exercício do capítulo anterior para caracterizar o surgimento de um tipo especifico de fotografia, a fotografia sobre meio ambiente, da qual as imagens fotográficas sobre o Protocolo de Kyoto fazem parte. Neste capitulo também se encontram considerações sobre a questão do gesto e do ato fotográfico que serão utilizadas no capítulo seguinte. 
No Capítulo 3, guiada pelas noções de gesto em Flusser e de sensação em Deleuze, apresento e discuto a maneira pela qual as imagens fotográficas sobre o Protocolo de Kyoto foram selecionadas para este trabalho e de como esse exercício de seleção já é, em si mesmo, um gesto fotográfico que participa de um ato fotográfico mais amplo.

No Capítulo 4, tento realizar uma "sintese conseqüente" das tentativas esboçadas nos três capitulos anteriores, sem, contudo, pretender encerrar as inúmeras possibilidades de ampliação da reflexão ora proposta. 


\section{Capítulo 1 :: Pensamento ecológico e imagem do mundo ::}

1 :: A relação Homem-Natureza: o mítico e a ruptura incompleta ::

2 :: Escritura e a concepção de unidade da Natureza ::

3 :: Formação discursiva e o pensamento ecológico contemporâneo ::

:: Referências Bibliográficas ::

\section{1 :: A relação Homem-Natureza: o mítico e a ruptura incompleta ::}

As famosas marcas deixadas em cavernas $^{1}$ da Europa e da África são tradicionalmente consideradas o início da expressão artística humana e as primeiras evidências arqueológicas sobre a capacidade de linguagem do Homem, sendo utilizadas por historiadores e antropólogos como registros que remetem necessariamente aos primórdios de uma organização social e cultural.

Para nós, essas primeiras inscrições, desenhos e pinturas, elaboradas na Idade da Pedra Lascada, mais precisamente no Paleolitico Superior (que vai de 25.000 a 5.000 a.C.), são, antes, impressões que o Homem Pré-histórico tinha do seu ambiente natural. São registros de sua "visão de mundo", de um modo de se relacionar com a natureza que evocava uma unidade, entendida e percebida como existente entre o Homem e a Natureza.

Essa "evocação" foi, sem dúvida, parte de rituais míticos do Homem Pré-histórico e sua iniciação como organizador da "desordem" observada na Natureza, cujo controle, desde então, pretende ter. É o exercício de uma "representabilidade" de uma ordem operacional imposta ao mundo material como única ordem possivel, que garanta a sobrevivência humana face à rusticidade e imprevisibilidade da Natureza:

\footnotetext{
${ }^{1}$ As principais imagens arqueológicas foram registradas nas cavernas de Rodésia, na África, de 40.000 a.C., de Lascaux e Chauvet na França, de 17.000 a.C., de Trois Frères e Le Gabilou, também na França, de 15.000 a.C., e de Altamira, na Espanha, datada de 14.000 a.C.
} 
É uma estranha experiência descer nessas cavernas, muitas vezes seguindo por corredores baixos e estreitos, mergulhar no negrume do ventre da montanha e, súbito, ver a lanterna elétrica do guia iluminar a imagem de um touro. Uma coisa é evidente: ninguém teria se arrastado por tal distância, até as soturnas entranhas da terra, simplesmente para decorar um local tão inacessível. Além disso, poucas dessas pinturas estão claramente distribuídas pelos tetos das cavernas, exceto um punhado delas na caverna de Lascaux. Pelo contrário, são, às vezes, pintadas ou entalhadas umas sobre as outras, sem qualquer ordem aparente. A explicação mais provável para essas pinturas rupestres, ainda, é a de que se trata das mais antigas relíquias da crença universal no poder produzido pelas imagens; dito em outras palavras, parece que esses caçadores primitivos imaginavam que, se fizessem uma imagem da sua presa e até a espicaçassem com suas lanças e machados de pedra -, os animais verdadeiros também sucumbiriam ao seu poder. (GOMBRICH, 1999, p. 42).

No imaginário do Homem Paleolitico, cuja cultura é muitas vezes comparada à das populações indigenas das Américas, à dos Aborígines australianos, ou aos diversos povos tribais africanos, os animais são deuses ou mentores que ensinam o Homem a interagir com a Natureza, a se [com] portar em relação a ela, ao mesmo tempo em que fazem parte dela. O Homem se vê como extensão do meio natural e "fala/age com ele" por meio de seus mitos.

(...) os [povos] primitivos acreditavam que os animais, assim como a vegetação, as pedras e as estrelas, tinham vida espiritual e linguagens próprias às suas espécies. As observações primitivas sobre o comportamento animal, em particular, deram origem à conclusão de que os animais também tinham seus mitos e suas danças rituais. Daí a abundância de mitos que contam como visitantes humanos vão a reinos animais e aprendem a língua e os costumes da espécie, aprendendo, portanto, a respeitar essa forma particular de vida. Por vezes, esses mitos nos falam de seres humanos que aprendem tão bem a lição de um modo mais selvagem de viver, que não querem voltar ao mundo humano, preferindo perambular com o rebanho ou nadar com o cardume. Essas narrativas ilustram a interconexão e a interdependência de todas as formas de vida. Elas ensinam que é um erro ver diferenças de verdade entre as formas de vida. Elas têm ainda o efeito de santificar as formas de vida que descrevem. (TURNER, 1990, p. 12)

\footnotetext{
${ }^{2}$ Narrativas, como estas a que Turner (1990) se refere, remetem à importância do mito da unidade primal na espécie humana e estão também presentes em diversos produtos culturais da contemporaneidade: do filme "Natureza Selvagem" (Into the wild, 2007), de Sean Penn, à animação da Disney "Irmão Urso" (Brother bear, 2005), passando por "O homem-urso" (Grizzly Man, 2005), de Werner Herzog. Essas narrativas são formas de "revisitar" aquele mito, revalorizando-o (na animação da Disney) ou negando-os, quando a tentativa de "retorno" à unidade (Natureza) culmina com a morte (nos filmes de Penn e Herzog). Essas duas narrativas fílmicas, aliás, baseadas em histórias reais, mostram que, no limite, o atávico no Homem é a busca por sua identidade, cuja crença numa "essência" ligada ao natural faz com que se arrisque pelo ambiente selvagem sem se utilizar das técnicas racionalizadas do mundo moderno, por acreditar que pode confiar em seus "instintos animais" supostamente "dormentes". Os personagens retratados, nas narrativas de Penn e Herzog, parecem não se dar conta de que são animais civilizados, incapazes de sobreviver sob o domínio da natureza. O mito da unidade primal "institucionaliza", assim, um tipo de relação imediata entre o Homem e a Natureza. Destituído da mediação arcaica da ritualização,
} 
Essas primeiras manifestações artísticas referem-se a um Homem monista ${ }^{3}$, que concebe o mundo como uma realidade única, não separando o material, vivido, do espiritual, sentido/percebido; o "visivel", do "invisivel"; o "exterior", do "interior". Para o homem da Idade da Pedra Lascada (mais marcadamente do Paleolítico Superior), desconhecedor da agricultura e da domesticação dos animais, sempre temeroso com o dia de amanhã, desenhar esses animais poderia, de fato, significar a capacidade mágica de possui-los ${ }^{4}$.

As manifestações parietais são, assim, ilustrações pictóricas do mundo material que cercava os primeiros hominídeos: poder-se-ia dizer que são a própria imagem de mundo que aqueles hominídeos construíram a respeito desse entorno, apesar desse termo ter sido criado por Heidegger (1998) como uma noção moderna, identificada com o advento da Ciência. A Ciência é, sem dúvida, uma técnica avançadíssima em relação ao periodo que estamos tratando, mas para aqueles hominídeos, foi o desenho, como inscrição, que passou a ser a grande técnica, o grande diferencial de operação de pensamento, de construção de simbolizações e de atualização da relação Homem-Natureza. O fato da espécie humana ser capaz de marcar a pedra à tinta ou esculpi-la, deixando rastros de maior complexidade simbólica que os deixados por formigas, peixes e abelhas, mostra o início de um processo do qual o Homem nunca mais se afastaria. Para Turner (1990), mais do que símbolos, essas imagens pré-históricas remetem à necessidade de ritualização, inerente ao Homem (e a outras espécies animais):

O mito, como expressão básica do espírito humano, é necessariamente contemporâneo da própria cultura humana (...) ao regredir no tempo até onde os artefatos atualmente permitem, vemos, com toda a certeza, que algum tipo de atividade simbólica (da qual o mito é talvez o exemplo mais esplêndido) tem caracterizado as culturas humanas. (...) Comportamentos rituais já foram observados em espécies tão variadas quanto primatas e peixes. Os elefantes que encontram esqueletos de seus semelhantes rearrumam os ossos num padrão que lhes é intimamente satisfatório. Mesmo invertebrados, como formigas e cupins, talvez tenham rituais; as abelhas têm sua estranha e maravilhosa dança de rotação, que simboliza a distância e a direção entre a fonte alimentar e a colméia. Tudo isso sugere que, talvez, estejamos lidando,

que impunha regras de convívio entre os diferentes seres da Natureza, e das técnicas de dominação modernas, o Homem urbano é incompetente para sobreviver no inóspito ambiente natural.

${ }^{3}$ O termo monista, aqui, faz uma oposição genérica à dualidade cartesiana. Supomos que o Homem Pré-histórico via seu próprio corpo como extensão do ambiente físico que habitava, e ainda não demonstrava um pensamento em que a simbolização de suas próprias idéias poderia organizar uma estratégia de apreensão do mundo físico, separado de seu mundo 'interno', mental; seu raciocínio, enfim.

4 “Os primitivos são, por vezes, ainda mais vagos a respeito do que é real e do que é imagem. Certa ocasião, quando um artista europeu fez desenhos de animais domésticos numa aldeia africana, os habitantes mostraram-se nervosos: 'Se levar consigo nosso gado, do que iremos viver?' "(GOMBRICH, 1999, p. 40) 
aqui, com uma forma de comportamento, uma reação vital muito maior que pirâmides terraceadas, mais profunda do que cavernas. (TURNER, 1990, p. 09-11).

O que se observa, contudo, e que diferencia, de maneira relevante, a capacidade de ritualização do Homem de comportamentos, supostamente rituais, de outros animais é a dependência da simbolização mítica no que tange à escritura (DERRIDA, 2006). E é a entrada no universo da escritura que as inscrições parietais parecem nos revelar: esse processo que marca e delimita o apartamento do Homem de seu meio natural. As ritualizações que se sucederam na História Humana estão, assim, vinculadas a essa ruptura ${ }^{5}$.

Se tentarmos penetrar na mentalidade que criou esses símbolos sobrenaturais, começaremos a entender que não só a feitura de imagens nessas antigas civilizações estava vinculada à magia e à religião, como era também a primeira forma de escrita. A serpente sagrada na antiga arte mexicana era a imagem de uma cascavel, mas tendia ainda a desenvolver-se num signo para o raio e, portanto, a converter-se num caráter pelo qual uma trovoada podia ser comemorada ou, talvez, invocada. Sabemos muito pouco a respeito dessas origens misteriosas, mas, se, quisermos compreender a história da arte, será conveniente recordar, vez por outra, que imagens e letras são, na verdade, parentes consangüíneos. (GOMBRICH, 1999, p. 53; grifo nosso)

Das criações míticas paleoliticas às afecções de sentido ${ }^{6}$ no imaginário da modernidade, o Homem tem, na escritura, a característica que o difere de todas as demais espécies animais?

\footnotetext{
${ }^{5}$ Nesse sentido, a contestação de Derrida às proposições de Levis-Strauss parece-nos extremamente relevante: "Que o neolítico, a que se pode efetivamente atribuir a criação das estruturas profundas sobre as quais ainda vivemos, não tenha conhecido algo como a escritura. É aqui que o conceito de escritura, tal como é utilizado por um etnólogo moderno, parece singularmente estreito. A etnologia fornece-nos hoje em dia informações maciças sobre escrituras que precederam o alfabeto, outros sistemas de escritura fonética ou sistemas totalmente a ponto de fonetizarem-se. O caráter maciço desta informação dispensa nossa insistência." (DERRIDA, 2006, p. 159)

${ }^{6}$ Ao longo deste trabalho, optamos por utilizar a diferenciação entre os termos significaçâo e sentido, entendendo este último "como entidade não-existente" ou a expressão "do paradoxo das representações sem objeto" tal como proposto por Deleuze (2003): "No desenvolvimento de sua filosofia, após o livro Lógica do sentido, assistiremos a afirmação de que a filosofia é uma disciplina que trata da criação e invenção de conceitos. A tese de Deleuze é que o conceito remete ao acontecimento. Ora, procuraremos distinguir e compreender como se dá esta passagem do livro Lógica do sentido para o livro O que é a filosofia?. No primeiro, a questão do sentido está diretamente relacionada à proposição; já, no segundo, o sentido remete ao conceito. A idéia de acontecimento dá ao conceito um aspecto diferente daquele pensado por Aristóteles. Desta maneira, o pensamento de Deleuze procura apontar novas saidas para a filosofia. O nosso contacto com o mundo, dando-se através da superfície das coisas, nos faria apreender além das coisas, e suas imagens, os acontecimentos que as envolvem. Deleuze quer tornar relevante a idéia de que a linguagem e a superfície estão relacionadas. $\mathrm{O}$ que pensamos e falamos sobre as coisas passa pela superfície. O estatuto da idéia é superficial. A linguagem, somente atinge a significação quando se dá na superfície. A significação somente é possível pelo sentido que a envolve. $O$ acontecimento sinaliza para o sentido como a proposição para a linguagem. O que deve ser esclarecido é que Deleuze aposta no conceito filosófico como incorporal. (...) O apreço de Deleuze por Lewis Carroll fálo afirmar que este, ao distinguir diferentes modos de tratar o sentido, sinaliza também para a diferença entre significação e sentido. (LOPEZ, 2003, p.205-206)
} 
Caracteristica que nos separa, definitivamente, do mundo físico que nos cerca, demarcando, num primeiro momento, dois territórios de significação: o mundo "exterior" concreto e o mundo "interior" abstrato, tal qual uma versão primária da dualidade cartesiana.

Nossa hipótese é que, o desenhar nas paredes das cavernas pode representar dois tipos distintos de vivência (Erlebnis) $^{8}$ da imagem: o primeiro, em que o gesto ${ }^{9}$ de desenhar (FLUSSER, 1994) antecipa o gesto da caça ${ }^{10}$ e, dessa forma, o esforço mítico concentrava-se no exercício do desejo ${ }^{11}$ de sucesso, conectando um gesto a outro. Uma segunda forma de vivência é a do gesto de desenhar tornando-se registro do gesto de caça, o que diminuiria o valor mítico do gesto de antecipação que desenhar guardava. O gesto de desenhar passaria, então, a ser relato do gesto da caça e não mais um ritual de evocação das forças da Natureza para que "conspirassem" a favor do sucesso da caça. Há, decerto, nesse segundo tipo de vivência, um grau de misticismo, mas se instaura uma diferença na ordem do gesto, na função da ritualização e no seu valor de evocação.

As pinturas rupestres constituem, assim, um tipo de escritura que remete a um sistema de simbolos, operando por equivalência à criação e à apropriação. A simbolização institucionaliza-se

\footnotetext{
7 "Earl W. Count, num ensaio que resume grande parte das evidências desse tipo, sustenta que a fabricação de mitos não é apenas contemporânea da espécie humana, mas é 'um aspecto de nossa morfologia'. Ele destaca que os cérebros de todos os vertebrados têm partes dedicadas, primordialmente, a atividades neurológicas, mais antigas, até, do que os mamíferos e, portanto, do que os primatas e a linha evolutiva do homem. O processo simbólico que em última instância se manifesta como mito é, portanto, 'sintoma e reflexo de uma estrutura que foi composta tanto filogenética como ontogeneticamente por materiais primitivos que representam uma sucessão de elaborações'. Se encaramos as atividades simbólicas e, portanto,a fabricação de mitos dessa maneira funcionalmente arcaica, estamos abertos a entender os mitos não como ficções decorativas e superadas mas como reações instintivas e claras dos organismos à Vida. De acordo com Count, o símbolo deve ser entendido "como um meio de entrar em contato com a realidade, e não como artifício inventado para expulsar a realidade'." (COUNT, Earl W. Being and Becoming Human: Essays on the Biogram. Behavioral Science Series. New York, Van Nostrand Reinhold Co., 1973 apud TURNER, 1990, p. 11)

8 "Segundo Dilthey, a vivência é algo revelado no 'complexo anímico dado na experiência interna'; é um modo de a realidade existir para um certo sujeito. A vivência não é, pois, algo dado; somos nós que penetramos no interior dela, que a possuímos de uma maneira imediata, podendo, até, dizer que ela e nós somos a mesma coisa. 'A vivência', escreve Dilthey, 'é um ser qualitativo: uma realidade que não pode ser definida pela captação interior, mas que alcança também o que não se possui indiscriminadamente (...) A vivência de algo exterior ou de um mundo exterior se encontra diante de mim de uma forma análoga àquilo que não é captado e que só pode ser inferido' (MORA, 2001, p. 3035)

${ }^{9}$ Usamos, aqui, gesto, na acepção flusseriana, e que será discutido nos Capítulos 2 e 3.

${ }^{10}$ Desenhar, usado aqui como correspondência à noção de gesto de pintar ou o gesto de fotografar, propostos por Flusser (1994), enquanto caçar, é uma metáfora para o gesto de busca.

${ }^{11}$ Desejo entendido como "desejo produtivo" que opera tanto a tribo, como "máquina territorial primitiva", e o déspota como "máquina territorial selvagem”, tal como definem Deleuze e Guattari (1996).
} 
como escritura (pintura ou inscrição na parede da caverna) organizando um mundo onde a única forma de apropriação se dá pela mágica como ritual de inscrição que produz imagens e garante a sobrevivência da espécie. A simbolização pictórica, como gesto de desenhar, é ausência total: é o desejo de posse e de sucesso. É o desejo que antecede a escritura como inscrição parietal. A pintura rupestre de Lascaux seria ausência de uma presença, porque o místico é escritural, mas ainda não é voz, não é alfabeto. É o único fragmento de registro em que não se verifica o apagamento da voz: a inscrição instituida antes que o gesto de caça se vincule a deuses de uma oralidade alfabética/fonética. Inscrita na parede, a pintura é análoga a uma "lei", impondo ordem ao caos sonoro de grunhidos e gritos dos gestos da caça: matar o animal verdadeiro só é possivel desde que o mesmo seja desenhado como ferido mortalmente na parede da caverna. A vivência (Erlebnis) do gesto de desenhar é, paradoxalmente, inscrição pura e imagem pura.

Concebida como escritura, a arte rupestre constituiria, então, um tipo de contato "direto" entre Homem e Natureza, um conjunto de pinturas recorrentes de animais, desenhados do modo como são vistos em uma determinada perspectiva: o Homem Paleolítico parece marcado pela fruição pura e simples, imposta pela sedução e pela vivência (Erlebnis) da imagem e ilustra o que a sua visão, seu olhar, captava do meio, ainda que desprovido de escrita totalmente fonetizada:

\footnotetext{
Seja qual for a explicação aceita para as poucas, mas impressionantes figuras animais/humanas - o personagem fálico com cabeça de ave de Lascaux, o homem/bisão com chifres de Le Gabilou, o famoso dançarino mascarado e chifrudo de Trois Frères - quer os consideremos xamãs, feiticeiros ou apenas caçadores com peles animais perseguindo suas presas, somos confrontados com uma visão da gloriosa indivisibilidade da vida. Essa visão amadureceu num período marcado, talvez, por reduzidas inovações tecnológicas, mas governado pelos princípios generativos do mito arcaico, os quais não reconhecem divisões hierárquicas tais como as que separam o céu e terra, animais e humanos, corpo e alma. (TURNER, 1990, p. 15; grifo nosso).
}

Essa ausência de operação por divisões hierárquicas termina, entretanto, no periodo seguinte, o Neolitico, quando o Homem caçador, pescador e coletor desenvolve outras habilidades. $\mathrm{O}$ aumento gradativo da complexidade do cérebro humano permitiu uma maior interferência no ambiente natural, bem como uma maior elaboração das ritualizações em relação ao controle, entendido como necessário, que esse ambiente natural demandava. A experiência de geração após geração acabou por permitir ao Homem a descoberta da agricultura e da domesticação dos animais. Cunhada (equivocadamente, ao nosso ver) de revolução neolitica, porque se acredita ter 
sido a primeira revolução tecnológica da humanidade ${ }^{12}$, a invenção dessas técnicas foi mais um passo para a transformação das sociedades primitivas, criando novas possibilidades para um Homem nômade que pôde, então, optar pelo sedentarismo.

A sedentarização foi um processo lento e extremamente marcado por novas ritualizações que, gradativamente, impuseram uma ordem de separação cada vez mais intensa entre o espaço artifical (ou urbano) e o espaço natural (ou deserto, se considerarmos a história da origem das civilizações a partir do Oriente Médio):

Pode ser argumentado, ainda, que uma das maneiras mais apropriadas de definir o mito, talvez, seja entendê-lo como uma estratégia para controlar, tanto quanto para propiciar e cooperar. Neste contexto, muitos se lembrarão da teoria desenvolvida por antropólogos do século XIX afirmando que a representação lingüistica ou gráfica de alguma coisa é uma tentativa de estabelecer sobre ela algum tipo de controle. Sir James G. Frazer ${ }^{13}$ chamou isso de "magia simpática" e considerou o fenômeno como um dos dois princípios fundamentais de toda a prática mágica. Nesse sentido, o mito Zuni sobre a primeira caçada poderia ser entendido como uma tentativa de controlar a natureza com a ferramenta da linguagem. Essa perspectiva leva, logicamente, à conclusão de que todos os homens desejam controlar o mundo natural, mas que apenas alguns conseguiram desenvolver meios eficientes e sofisticados de controle. Então, o que separa o selvagem do civilizado é que, enquanto o primeiro tentou controlar o mundo conversando com ele e imitando-o com desenhos e danças, o segundo ultrapassou esses recursos patéticos e partiu para a invenção e o emprego de meios extra-somáticos que alcançaram, de fato, os objetivos desejados. Em termos de tecnologia, a diferença poderia ser ilustrada pelas expressões controle-pela-veneração e controle-pelo-uso. Ou, como muitos já observaram, é a diferença entre tratar o cosmos de "Vós" e tratar o cosmos de "Coisa". (TURNER, 1990, p. 21-22)

À medida que o gesto de desenhar deixa de expressar uma antecipação no processo de ritualização de evocação dos deuses e passa a registrar os resultados obtidos pelo gesto de caça, atualizando a relação material necessária à sobrevivência, o Homem aliena-se da Natureza, daquele contato mediado pelo mito arcaico e privilegiadamente imagético. A necessidade de magia continua, mas sua forma de operar se modifica: ao invés de centrar-se na antecipação, o Homem concentra-se no relato, na narrativa, na escritura como um "depois". A escritura torna-se, lentamente, mais rebuscada e surgem os alfabetos, que substituem a imagem visual (antes "pura" cópia de uma realidade sonhada sem palavras propriamente ditas) por signos abstratos e

\footnotetext{
${ }^{12}$ Nosso enfoque defende que, se há alguma importância em se determinar "a primeira grande revolução tecnológica" da humanidade, essa sem dúvida, já havia ocorrido pelo advento da escritura no Paleolítico.

${ }^{13}$ FRAZER, James G. The (New) Golden Bough. New York: Theodore Gaster Ed., 1964.
} 
geométricos (o simbólico, representação da realidade vivida por signos ou a metafísica da presença, como expõe Derrida, 2006). O Homem não se vê mais como extensão do mundo natural, como mais um entre muitos elementos da Natureza, mas como um animal diferente, apartado dela ${ }^{14}$. A hierarquização entre céu e terra, animais e humanos, corpo e alma tem início e instaura os rudimentos da operação de um pensamento escritural, fonético e dual.

Esse esquema mostraria a passagem de um curto periodo de ritualização não-hierárquica e monista, típica da visão "reproducionista" e mítica do Homem Paleolítico, para um longo e duradouro período de relação Homem-Natureza marcado pela hierarquização e pela presença de um dualismo (o dentro e o fora, o humano e o não-humano) e da metafísica do signo. Essa diferenciação, iniciada pelos primeiros grupamentos humanos do Neolitico, corresponderia a um distanciamento crescente, uma ruptura com o mundo natural e o estabelecimento de uma relação primordial do Homem com a Natureza, expressa por formas de simbolização cada vez mais complexas: maneiras de compreender e interpretar o mundo que aos poucos irão distanciandose do mítico imagético, escritural e não-alfabético para o mítico metafísico, da escritura fonética, de lógica linear discursiva. Uma separação que jamais será reatada e que é característica da nossa espécie ${ }^{15}$ :

Uma tese que pode ser levantada legitimamente é a de que o mito, mesmo em seu estado mais primitivo, é uma prova de que o homem já rompeu com o resto da criação, que sua capacidade de simbolizar e conceituar animais e outras formas de vida (embora estas estejam curiosamente ausentes na arte parietal do paleolítico) e, até, a concepção integral da vida, indicam que a unidade primal, tão ardentemente desejada, foi perdida. Talvez, seja este o real significado daquelas mãos fantasmagóricas e antigas pintadas nas paredes das cavernas, pois é a mão humana com a maravilhosa habilidade garantida pela oposição entre polegar e indicador, juntamente com a expansão de nosso córtex cerebral, que faz do Homem o que ele tem de ser: aquele animal que

\footnotetext{
${ }^{14}$ Outros aspectos da origem dos israelitas são revelados pelo mito de cosmogênege que abre as escrituras, pois trata-se de uma lembrança e de um reflexo dos desejos de um grupo nômade do Oriente Médio, registrados por um escriba depois que o povo se tornou sedentário. Não é difícil imaginar que esse povo contemplou os jardins das cidades da Mesopotâmia como o Paraíso. E, de fato, é precisamente assim que o Éden é imaginado: um daqueles jardins murados mesopotâmios onde se conservavam diversos animais e aves para fins estéticos e de caça. Aqui, até mesmo o próprio Deus Todo-Poderoso, como um potentado oriental, busca a sombra refrescante para fugir do calor do dia (Gênesis 3:8). Como diz Paul Shepard, para os habitantes das cidades esses jardins eram um reconhecimento formal das delícias da natureza, não a natureza crua ou autêntica, mas uma natureza domada, humanizada e cercada de muros, tal qual as cidades. (TURNER, 1990, p.39; grifos nossos).

${ }^{15}$ Essa ruptura primeira com a mãe-natureza - a unidade primal - poderia, também, ser ilustrada pela idéia de ruptura primeira, do Homem constituído pela linguagem, a qual Lacan (1998) se refere como o corte simbólico: o estabelecimento do Outro, o significante primeiro da linguagem, da História, da vida social, instaurador da subjetividade humana.
} 
consegue se imaginar e imaginar outras coisas, que faz distinções e separações, que consegue enxergar um futuro e sentir falta de um passado. (TURNER, 1990, p. 21; grifo nosso)

Esse processo de ruptura é intensificado por outra importante aquisição técnica do Neolítico: a constituição das cidades ${ }^{16}$. A cidade transforma novamente o universo mítico e permite que configurações do imaginário abandonem definitivamente concepções da Natureza típicas do período anterior. Deuses deixam de ter formas animais e passam a ser representados por figuras totalmente humanas, com emoções e defeitos humanos, como nas mitologias grega, romana e egipcia. Lentamente, o Homem transforma sua concepção do mundo material "visível" e as simbolizações míticas dependentes de uma relação próxima, quase íntima, com o ambiente natural, desaparecem. Essa modificação de concepção tem efeitos drásticos na relação HomemNatureza. Ao aumento de antropomorfização ou antropocentrismo no imaginário, corresponde um aumento da dominação sobre o ambiente natural:

Quando aumentou a densidade das populações humanas, e estas começaram a se organizar em comunidades com estruturas sociais cada vez mais aperfeiçoadas, rapidamente dispuseram de um poder crescente à medida que os seus recursos técnicos se desenvolviam. Nessa época, o homem podia ainda ser considerado como um elemento natural, ao mesmo título que qualquer outra espécie animal; mas não permaneceu muito tempo nessa situação de igualdade: a evolução que conduz aos tempos modernos já tinha iniciado. No fundo, a história humana pode ser encarada como a luta da nossa espécie contra o meio em que se insere e sua emancipação progressiva relativamente à natureza e a algumas de suas leis, como o domínio progressivo do homem sobre o mundo, com seu solo, suas plantas, e seus animais, submetidas às invenções do gênio humano. (DORST, 1973, p.19)

\footnotetext{
${ }^{16}$ Heiser (1977) afirma que explicar porque o homem transformou-se de caçador-coletor em agricultor ainda é alvo de especulação por parte dos arqueólogos. "V. Gordon Childe, que criou o termo Revolução Neolítica para designar a invenção da agricultura pelo homem, acreditava que uma mudança climática que trouxe a seca reuniu homens e animais nos locais onde havia água e, essa associação, estimulou a domesticação de animais. R. J. Braidwood argumentava que, sem grandes mudanças climáticas, a produção de alimentos se desenvolveu 'como resultado final de uma sempre crescente diferenciação e especialização cultural das comunidadews humanas' Ele pressupõe que fazia parte da natureza humana inventar a agricultura quando o homem já se havia familiarizado grandemente com os seus recursos vegetais e animais. Lewis R. Binford, rejeitando os argumentos de Childe e Braidwood, achava que a pressão demográfica foi o instrumento: um aumento da densidade da população levou o homem à tentativa de manipular o ambiente a fim de aumentar a produçõa de alimentos." Heiser cita Kent Flannery e Carl Sauer, mas destaca a posição de Jane Jacobs, que discordava de todas as hipóteses anteriores: "Acredita ela que foram as cidades que deram origem à agricultura, e não o contrário, como em geral se afirma. Argumenta que as primeiras cidades surgiram como centros de comércio e que a agricultura realmente se desenvolveu dentro delas, sendo mais tarde transferida para as zonas periférica. Ela torna o caso interessante, em particular quando conjectura que os animais trazidos à cidade para as barganhas seriam conservados vivos até que deles se precisasse, o que evidentemente poderia constituir o primeiro passo para sua domesticação." (HEISER, 1977, p.16-17)
} 
A noção de Natureza e a relação que o Homem estabelece com ela, passam, cada vez mais, a estar comprometidas por uma concepção de dominação pela força:

(...) o aparecimento da civilização no Oriente Médio, da forma como o Ocidente depois o entenderia, tem o aspecto concomitante e altamente significativo da superação de sentimentos mais antigos e orgânicos: a gratidão à Natureza e a interdependência vital de todas as coisas. Esses sentimentos foram deslocados pelas noções masculinas de confrontar a força com outra força e da oposição permanente entre Homem e Natureza. A velha concepção de uma terra-mãe e fecunda foi transformada na simbologia de uma luta vencida, com o falo metálico do arado introduzindo a sua semente grávida no sutilmente resistente útero/solo. As cidades verticais e estéreis, reluzindo na paisagem, esculpiam leões e bois para vigiar seus portões contra todos os perigos exteriores. Da forma que emergiu nessa região, a civilização conscientemente criou muros que a separavam das harmonias orgânicas e se definiu em termos de oposições. Como diz Joseph Campbel1 ${ }^{17}$, esse ponto de vista "se diferencia da visão arcaica mais antiga por colocar todos os pares de opostos macho e fêmea, vida e morte, verdade e mentira, bem e mal - como se fossem expressões absolutas em si mesmas e não meros aspectos da entidade mais ampla da vida". Mumford ${ }^{18}$ chama essa mitologia da revolução neolítica de "mitologia do poder" e diz que suas culturas tinham "personalidades envoltas em armaduras". Agora, essas culturas exerciam poder não apenas sobre os animais selvagens que por tanto tempo hostilizaram pastores e agricultores, mas, ainda, empregando seus novos músculos, tentavam controlar toda uma natureza que parecia resistir com suas próprias forças à força da civilização." (TURNER, 1990, pg.30)

A consolidação das cidades como principal forma de ocupação do espaço natural e de organização social, estabelece uma maneira de relação com a Natureza que não é mais passivel de modificação. A relação Homem-Natureza passa a ser experimentada e vivenciada a partir desse espaço transformado pelo Homem, - a cidade -, de onde o ambiente natural é observado e se consolida a concepção de algo que é externo ao Homem, do qual ele depende, mas não faz parte.

A Neolitização é um processo que dá continuidade ao desenvolvimento e acúmulo de arsenal técnico, incitando uma nova etapa: uma revolução simbólica fundamental e de impacto tão importante quanto a sedentarização dela resultante. O processo de apropriação da Natureza é possivel graças a essa nova simbolização em relação a ela.

Ali, no Oriente Médio, a difícil evolução dos acampamentos nômades até os vilarejos e vilas que eventualmente chegaram a ser grandes cidades - vitória

\footnotetext{
${ }^{17}$ CAMPBELL, Joseph. The masks of God: occidental mythology. New York, 1970.

${ }^{18}$ MUMFORD, Lewis. Technics and civilization. New York: Burlingame, 1963. [e também] history: its origins, its transformations and its prospects. New York, 1961. The city in
} 
que levou milhares de anos num meio ambiente dificil - deu origem à crença de que "civilização" significava a cidade murada, edificada e cheia de grãos armazenados e que essa civilização só podia ser alcançada e precariamente mantida com a guerra implacável e direta contra uma natureza que, por si mesma, pouco dava ao homem. O excedente, esse elemento que protegia o homem civilizado do capricho da natureza, que distinguia a cultura da selvageria e do inculto, era produzido pelo trabalho humano, com ajuda não da terra, que era hostil, mas dos deuses do céu, distantes da terra. Enquanto as mitologias dos povoamentos humanos mais antigos parecem ter se baseado ao menos em parte na terra, o desenvolvimento das cidades transferiu o locus da divindade para o céu e para os deuses irracionais e violentos que o habitavam. (TURNER, 1990, p. 24)

Parece, assim, que é o surgimento da simbolização, primeiro como escritura imagética e mais tarde como escritura fonética, que marca, tanto o aparecimento de uma cultura propriamente dita, - no sentido mais tradicional que o termo cultura possa ter -, como também, e fundamental para nossa questão, uma alteração inexorável da relação Homem-Natureza, baseada numa modificação da percepção e interpretação do mundo, resultado do caminho evolutivo da espécie humana: a habilidade de simbolizar, mesmo bem antes do aparecimento das línguas, as mais antigas e rudimentares, precipitou uma ruptura sem precedentes entre o ambiente natural e o Homem. A partir de um "falar/agir com a Natureza”, o desenvolvimento da capacidade de simbolização conduz a um "falar/agir sobre a Natureza" que se constitui, definitivamente, como algo externo ao humano e funda uma relação que irá perpetuar-se até os dias de hoje.

Os humanos se posicionam no mundo através de linguagem e símbolos, e não se pode minimizar a importância, para a destruição da vida e a degradação da biosfera, de uma identidade afirmada sobre uma imagem consciente/inconsciente da natureza como objeto externo e coisificado, e, portanto, passivel de ser conquistado e dominado. (LEIS, 1991, p. 11).

Por outro lado, porém, parece que a partir da invenção da escrita, ao mesmo tempo que Homem perde parte de sua habilidade mitica de viver na Natureza, ou vivenciála imeditamante, cria novas formas míticas de "comunicar-se" com a ela. Se comunicação é vínculo", o Homem constrói, também, novas formas vinculativas com as quais passa a simbolizar "o natural”, seja ele metáfora para as plantas, gatos e cachorros dentro de casa; os passarinhos na gaiola e os peixes em aquários; as férias na praia ou na montanha; os passeios ou shows nos jardins

\footnotetext{
${ }^{19}$ BAITELLO Jr., Norval. Informação oral. Disciplina 1815-A Fundamentos da Comunicação. Programa de Pós Graduação em Comunicação e Semiótica. PUC-SP (Área de Concentração: Signo e significação nas mídias/Linha de Pesquisa: Epistemologia da comunicação). Ago. a Dez. 2006.
} 
públicos; a savana africana ou a floresta amazônica; a defesa dos gorilas ou das baleias antárticas.

O "comunicar-se" com a Natureza ganha, por um lado, outros padrões rituais ou a sisudez da escritura analitica cientifica, até o ponto em que se considera que a comunicação só pode atualizar-se a partir de um "estar dentro" que é ser humano e que, por isso, a espécie humana tornou-se um conjunto de sistemas ${ }^{20}$ separada do universo natural, só sendo capaz de observá-lo e de descrevê-lo e que qualquer tentativa que desconsidere este fato é sedução pela antropomorfização do natural e de tudo que lhe diz respeito.

Vemos, ao longo da História, a transformação ou a passagem de um Homem míticoimagético, que fala "diretamente" com os animais e as plantas, para um Homem mitico-narrativo (judeu, cristão ou muçulmano), para o qual todas as figuras míticas são prioritariamente humanas e ilustram ou defendem interesses de convivio social de homens com homens e não de homens com animais, plantas, montanhas, rios e lagos. O Homem mítico-narrativo concebe deuses - ou a Ciência - como formas capazes de mediar sua relação com os "mistérios" da Natureza.

Já foi dito que a equivocada atribuição de vida espiritual ("animismo") a componentes não-humanos do mundo dos fenômenos impediu que os primitivos vissem o mundo como ele realmente é, impediu que eles identificassem o funcionamento de processos, os manteve como prisioneiros do mundo ao invés de lhes permitir alcançar a posição de senhores desse mundo. Como acreditavam ver e sentir a vida e alma em todos os lugares, os primitivos, segundo essa visão, viviam ansiosamente submetidos a muitos centros de poder, assaltados por angústias sem fundamento, marcados por atos grotescos de contrição e superstição. (TURNER, 1990, p. 17)

O fim da Pré-história marca o início de uma relação Homem-meio natural que se perpetua ao longo da evolução técnica e tecnológica. À medida que as civilizações ultrapassam períodos de escassez e de fartura, de colapso e de sucesso, esses elementos característicos de uma escritura que institui o humano e que, ao mesmo tempo rompe com o natural, impõem-se e são cristalizados como formas de expressão da lógica que opera por pares de opostos, fortalecendo o

\footnotetext{
20 "Peixes e seres humanos podem vir a morrer porque nadar em mares e rios tornou-se algo insalubre. Poços de petróleo podem secar e as temperaturas médias podem eventualmente subir ou descer. À medida que isso não ocupa o lugar de sujeito de comunicação não possui efeito social. Sociedade é um sistema ambientalmente sensivel (aberto), mas operacionalmente fechado. Seu único modo de observação é por comunicação... Portanto ela pode somente expor a si própria ao periga.." (LUHMANN, 1989, p. 28-29; itálico do autor)
} 
pensamento linear típico das narrativas racionais e dedutivas, desde os gregos até o estabelecimento da Ciência Moderna.

Será apenas após o Renascimento, com o início da era moderna, que essas operações se constituirão como representações propriamente ditas, no sentido heideggeriano ${ }^{21}$ do termo: estabelecimento de novas visões de mundo, um mundo organizado pela escritura fonetizada ocidental, cujo desenvolvimento se baseia no discurso técnico-científico, mas cujo ideal de progresso civilizatório é vinculado ao sagrado pela primazia de uma metafísica presente também como escritura fonética judaico-cristã.

(...) no século XV, quando as investidas exploratórias do Ocidente, além de
suas fronteiras geográficas, começaram a assumir a solenidade de um plano, a
civilização estava dominada por atitudes profundamente enraizadas e muito
antigas em relação à natureza indomada e mesmo à natureza não aproveitada
pelos humanos, em relação aos homens que habitavam a natureza virgem e em
relação aos laços a serem estabelecidos entre a "civilização" e os habitantes da
natureza virgem. Essas atitudes, codificadas e implantadas nas escrituras, são,
de fato, derivadas das lutas que os povos do antigo Oriente Médio travaram
com o seu meio ambiente marginal e inconfiável." (TURNER, 1990, p. 22-23;
grifo nosso)

Ainda, se a metafísica da presença na escritura fonética imiscui-se em toda a racionalidade científica moderna, como aponta o conceito de escritura desenvolvido por Derrida (2005, 2006), a transcendência divina persiste, ainda, e alimentará construções imaginárias da percepção de Natureza nos séculos que marcam o início da Modernidade 22 .

\footnotetext{
${ }^{21}$ Para Heidegger a modernidade é marcada por esse novo modo de operação (intelectual, cultural, social, histórica) em que o mundo passa a ser "representado" ou seja, elaborado pelo Homem. Porém, "diferenciado-se do percepcionar grego, o representar moderno, cujo significado é expresso aproximadamente pela palavra repraesentatio, quer dizer algo muito diferente. Re-presentar significa, aqui, trazer para diante de si o que-estáperante, enquanto algo contraposto, remetê-lo a si, o que representa, e nesta referência, empurrá-lo para si como o âmbito pragmático. Onde tal acontece, é o homem que, sobre o ente, se põe como imagem. Mas na medida em que o homem, deste modo, se põe como imagem, ele põe-se a si mesmo em cena, isto é, no círculo aberto do que é universal e publicamente representado. Com isso, o homem põe-se a si mesmo como a cena, na qual o ente doravante se tem de re-presentar, presentificar [präsentieren], isto é ser imagem. O homem torna-se no que representifica [Repräsentant] o ente, no sentido do que é objetivo.” (HEIDEGGER, 1998, p. 114-115)

${ }^{22}$ Modernidade não é, para nós, um conceito, mas uma convenção relativa que serve de acordo instrumental para a pesquisa de um determinado grupo, definindo o início de um processo. Como explicita Jameson (2005), esse acordo está longe de encontrar termos comuns dentro das diversas áreas das ciências humanas: " Modernidade' significa sempre estabelecer e postular uma data e um começo. (...) para os filósofos, a total ruptura de Descartes com o passado constitui não somente a inauguração da modernidade, mas já uma teoria autoconsciente ou reflexiva da mesma; ao passo que o próprio cogito representa a reflexividade como uma das características centrais da modernidade. Numa visão retrospectiva - a retrospectiva do século XX e da colonização - parece-nos agora claro que a conquista das Américas trouxe consigo um significativo elemento novo da modernidade, embora,
} 
Além disso, a presença do místico ou metafísico não persiste apenas pela escritura fonética, que representa a fala, a voz do ser divino, mas, também, pela permanência da fala divina atribuida aos fenômenos naturais. As catástrofes e desastres passam a ser, assim, expressão de um deus belicoso e cheio de caprichos (apesar dos infindáveis esforços mitológicos para justificar a ira divina pela existência do mal):

(...) o deus falará aos homens com as temíveis sílabas dos desastres naturais. (...) por mais que o judaísmo (e o cristianismo seu descendente) seja hoje encarado como uma religião da cidade, o seu campo psicoespiritual é o das estepes e dos desertos: seu deus é um deus dos lugares selvagens e ele exige ruidosamente que o seu povo não esqueça disso nem de que veio da selvageria. (...) Suas palavras são erupções vulcânicas, tempestades com trovoadas e terremotos. $O$ efeito cumulativo de tudo isso é o de enfatizar os aspectos destrutivos da natureza e de reforçar a atitude antropocêntrica e belicosa em relação ao mundo natural anunciado no mito do paraíso (TURNER, 1990, p. 41-42; grifo nosso)

A escritura deixa de ser o registro da cena pré-visivel para ser o momento do registro da voz, da presença da voz. O gesto de desenhar transformado em gesto de escrever ganha, agora, outra significação: passa a ser mediação entre a voz divina e qualquer gesto humano. A Natureza só é internalizada como fonte de sinalizações do divino e percebida, nessa novo tipo de mediação como dificuldade a ser vencida e fonte de materiais para se dispor. O Homem é, então, coordenado, gerenciado, orientado pela voz, seja ela escritura científica ou catástrofe natural, cujos registros organizam o caos do mundo e determinam os rumos da existência humana. A relação entre o mítico e o natural fica reduzida ao gesto de escrita que representa, de uma maneira ou de outra, a presença inexorável do metafísico.

Por expressar uma relação ontológica que opõe drasticamente e define essencialmente o sensível como marca do Natural, e o inteligivel, como marca do artificial, do cultural, da origem divina, da oralidade, o discurso ecológico carrega, de maneira indelével e exemplar, a metafísica da presença.

tradicionalmente, tenha sido a Revolução Francesa e o Ilumisnismo que a prepararam e acompanharam, sendo ela considerada como a mais importante ruptura social e política da modernidade. No entanto a lembrança da ciência e da tecnologia nos leva, repentinamente, por todo o caminho de volta a Galileu, se não estivermos satisfeitos em afirmar a existência de uma revolução alternativa à Revolução Industrial. Mas Adam Smith e outros fazem da emergência do capitalismo uma inevitável opção narrativa, enquanto a tradição alemã (e, mais recentemente, Foucault em The Order of Things) afirma a importância desse tipo especial de reflexividade, que é historicista, ou no sentido da história em si mesma." (JAMESON, 2005, p.43-44). Para os fins desta pesquisa, Modernidade é o periodo que se inicia a partir do estabelecimento da ruptura entre o valor da escritura científica e o valor da escritura sagrada, a partir dos esforços de Galileu, no século XVI. 
Nossa vivência “original” de Natureza como fruição de imagens está para sempre perdida nos registros parietais das cavernas. Agora ela é mediada por um inteligivel já inscrito nas diversas formas de escritura, especialmente a cientifica, quer biológica, quer econômica. No que tange ao que entendemos por Natureza, nosso potencial de compreensão está cindido, para sempre mergulhado na clausura da escritura ${ }^{23}$, de uma mediação que procura escapulir ao domínio do mítico, como prática, e adentra a alienação do mítico como metafísica inconsciente, como presença da voz que se apaga ${ }^{24}$.

Paradoxalmente, na produção de conceitos como ecologia, ecossistema, sustentabilidade estão implícitos valores de unidade, de todo, de continuidade, de equilíbrio, de harmonia, de sabedoria de um ser supremo, advindos dessa mistura entre mitologias anteriores ao surgimento do judaísmo e de crenças em valores judaico-cristãos:

O interventor divino, que cria a partir de uma unidade primordial separações e divisões e uma hierarquia antropocêntrica, dá sanção divina a essa atitude. Todos os mitos de cosmogênese descrevem separações, pois esse é o significado de criar. Foi o Ocidente, no entanto, que levou essa regra à sua expansão mais candente: "Crescei e multiplicai-vos, e renovai a terra; e dominai os peixes do mar, as aves do ar e todas as coisas vivas que se movem na superficie da terra." Espiritualmente, essa visão está a anos-luz daquela comunidade mítica da vida gravada nas paredes das cavernas e que permeava a vida tribal nas florestas e ao longo dos rios da América aborígene; ela continua enterrada dentro de nós como uma memória filogenética. (TURNER, 1990, p.39)25

No que tange ao discurso científico, que legitima e faz circular nos meios de comunicação a temática da sustentabilidade, o apagamento pela escritura como expressão máxima do

\footnotetext{
${ }^{23}$ A entrada na temporalidade da escritura parece, aí, ser um momento filogenético da espécie humana, repetido em cada indivíduo pela idéia do corte simbólico lacaniano, como se este representasse, no desenvolvimento ontogenético, o momento da inserção na temporalidade escritural, isto é, da lógica linear da escrita.

${ }^{24}$ Em "Freud e a cena da escritura", Derrida (2005) discorre sobre a questão do apagamento da escritura com base na metáfora freudiana do bloco mágico. Analogamente, no processo de escrita, a escritura "artificial" e fonética da Ciência, apaga-se a escritura "natural", fônica, da voz divina. O mito, presente de diversas maneiras na atividade científica, como busca da verdade, da neutralidade, da objetividade, como metafísica da presença, como significante primeiro da fala, apaga-se pela escritura "artificial" e, contudo, permanece, ainda, operante nela.

${ }^{25}$ Turner (1990) crê que haja um registro genético, como se fora um resquício evolutivo de estágios primitivos, gravado em nosso DNA, e que determina nosso vínculo místico com a Natureza da mesma maneira que Lacan propõe o corte simbólico como determinante da existência social. Essa é, em si mesma, a mística do vínculo primal com a mãe-natureza, que se restabelece, também, na história do pensamento humano acerca da relação Homem-Natureza. Essa crença na possibilidade de volta a uma relação original não deixa de ser o constituinte do imaginário social contemporâneo no qual o discurso ecológico se funda. $O$ retorno à Natureza preconizado por algumas manifestações do discurso ecológico parece remeter à busca pelo objeto de desejo primeiro, o "Outro" natural - a 'mãe' Natureza, a 'mãe' Terra -, o significante primeiro da coletividade humana, esse "Outro" imaginário que a vida biológica nos remete incessantemente e cuja ruptura ocorre pela existência social.
} 
racionalismo cientifico é complexificado (MORIN, 2003) uma vez que a origem mesma da temática repousa sobre construções mitológicas sobre a Natureza e sobre o divino na Natureza.

Aquele contato "original" conclamado pelos mitos de unidade entre todos os componentes da natureza é perdido à medida que o Homem avança tecnologicamente ${ }^{26}$. Mas os mitos permanecem como vínculo àquele pré-histórico onde a Natureza "reinava" e não havia a voz do ser supremo. A "realidade" desse percurso que adentra o histórico pela escritura fonética pode apenas ser "medida", ou seja, detecta-se a distância em que cada civilização está, tecnologicamente, em relação àquele estado "original" considerado "pobre” em tecnologias, mas rico em mitos arcaicos e simbolizações imagéticas e a-fonéticas.

O ambientalismo tem um núcleo contraditório e enganoso porque permite acreditar que a humanidade pode estabelecer uma relação de equilíbrio com a natureza sem devolver-lhe nem lhe reconhecer um papel ativo e criativo, procurando assim de fato adaptar o projeto ecológico ao projeto dominante em nossa civilização. (LEIS, 1991, p.11).

Essa visão de unidade entre as diversas formas de vida é uma das características do movimento romântico que se opôs à visão analítica e racionalista da Ciência Moderna, fruto do casamento do Iluminismo com a Revolução Industrial dos séculos XVIII e XIX. É essa ruptura "inaugural” entre Natureza e Cultura que o Romantismo vai confrontar, revalorizando o sensivel (a Natureza ou o natural) como única forma de compreensão e de vivência possivel.

\section{2 :: Escritura e a concepção de unidade da Natureza ::}

Acot (1990) remete à História dos animais ${ }^{27}$ como o ápice da obra "ecológica" de Aristóteles (384 a.C. - 322 a.C.), defendendo que esta deveria configurar-se apenas como uma, entre outras

\footnotetext{
${ }^{26}$ Nenhum turista explora "terras virgens" como nossos ancestrais tribais o faziam. Talvez, mesmo, poucos povos do planeta ainda o façam. E mesmo os contemporâneos de Cristóvão Colombo guiavam-se por mapas, escrituras planificadas, que permitiram intuir/deduzir a existência de outros continentes ou a forma arredondada do planeta. Não cultivamos mais a terra (compramos tudo pronto nos supermercados): cultivamos uma idéia do que a terra é. Para o cidadão urbano, maioria da população humana mundial, a única forma de contato com a Natureza é o turismo. Viajar é uma maneira mediada de conviver com a paisagem, com o natural, destituída de mitos e que leva consigo parte do conforto da vida urbana. Mesmo nos chamados "acampamentos selvagens" não voltamos às eras da caça, nem vivemos da natureza como nossos ancestrais das cavernas.
}

${ }^{27}$ ARISTOTE. Histoire des animaux, I, 1, Paris: Les Belles Letre Denöel apud ACOT, 1990, p. 2. 
possibilidades, - por exemplo, Teofrasto e Plínio, o Velho -, de se reunir, na Antiguidade, os precursores da ecologia.

Entretanto, a noção de unidade que caracteriza o discurso ecológico contemporâneo e que é atribuida à palavra ecologia, não se baseia apenas na assunção de uma separação sistemática e classificatória entre os seres vivos tal qual o Estagirita organiza na referida obra.

A idéia de Natureza como unidade é uma construção da escritura cientifica moderna que remete à história de sistemas de pensamentos que se cruzam para constituir a significação de dois conceitos: ecologia e ecossistema.

A primeira palavra, ecologia, tem paternidade marcada: Ernst Haeckel (1834-1919) cunhou-a em 1866, em uma nota de pé de página de sua principal obra, Generelle Morphologie der Organismen, produzida em dois volumes ${ }^{28}$. Haeckel justificava uma proposta de substituição do termo biologia, "cujo sentido, na época, era indevidamente restrito", por ecologia, "a ciência da economia, do modo de vida, das relações vitais externas dos organismos etc." ${ }^{29}$ (ACOT, 1990, p. 27).

\footnotetext{
${ }^{28}$ Golley (1993) cita a existência de uma tradução para o inglês do parágrafo em que Haeckel define a palavra ecologia: "By ecology we mean the body of knowledge concerning the economy of nature - the investigation of the total relations of the animal both to its inorganic and its organic environment; including above all, its friendly and inimical relations with those animals and plants with which it comes directly and indirectly into contact - in a word, ecology is the study of all those complex interrelations referred to by Darwin as the conditions of the struggle for existence. This science of ecology, often inaccurately referred to as 'biology' in a narrow sense, has thus far formed the principle component of what is commonly referred to as 'Natural History' " (HAECKEL, 1866 apud AllEE, W. C.; EMERSON, Alfred E.; PARK, Orlando; PARK, Thomas; and Schmidt, Karl P. Principles of Animal Ecology. Philadelphia, W.B. Saunders, 1949. apud GOLLEY, 1993, p. 207). [ "Por ecologia nós queremos dizer o corpo de conhecimento concernente à economia da natureza - a investigação das relaçoes totais do animal, considerando ambos seu ambiente inorgânico e orgânico; incluindo, acima de tudo, suas relações amigáveis e adversas com esses animais e plantas com que tem diretamente e indiretamente em contato - para resumir, a ecologia é o estudo de todas essas relações mútuas complexas referidas por Darwin como as condições da luta pela existência. Esta ciência da ecologia, freqüentemente e incorretamente referida como "biologia" num sentido estreito, até aqui constituiu o componente do princípio ao qual comumente é referida a 'História Natural' “.Tradução Livrel. Curiosamente, Golley usa, também, uma nota de rodapé para citar a tradução da definição inicialmente dada em nota de rodapé por Haeckel. Talvez esse uso sistemático de notas de rodapé como lugar de definições pudesse explicar a coincidência com o uso histórico e epistemológico da palavra ecologia separadamente da definição que the deu origem.
}

\footnotetext{
${ }^{29}$ Acot (1990) cita, ao todo, seis definições possiveis para a palavra ecologia, dadas por Haeckel em obras distintas, produzidas ao longo de sua vida. A versão da definição original que Acot (1990) apresenta em seu livro é a seguinte: "Por ecologia entendemos a totalidade da ciência das relações do organismo com o meio ambiente, compreendendo no sentido lato, todas as condições de existência" (HAECKEL, 1866, v. II, p. 286 apud ACOT, 1990, p. 27)
} 
Lembrado apenas por esse feito neologista na maioria dos poucos livros que remetem a história da ecologia à história do ambientalismo, Haeckel foi, na verdade, um dos mais famosos e influentes pesquisadores alemães do século XIX:

In virtually all studies of the history of ideas in the nineteenth century, Haeckel is seldom, if ever, separated from the general progressive, scientific, and modernistic tradition of European culture and his name is found to be synonymous with materialism, naturalism, mechanism, and of course, Darwinism. He is traditionally been thought to embody optimism, progress, liberalism, socialism, and tireless opposition to arbitrary state power. He is invariably accepted as the intellectual embodiment within Germany of the feeling of optimism and security, engendered by science and industrialism, which suffused bourgeois civilization before the cataclysm of 1914 . (GASMAN, 1971, p. xiv) $)^{30}$

Para Acot (1990), com a invenção do termo ecologia, Haeckel pretendia, de um lado, nomear um novo campo científico, que ainda não estava instituido, mas cujo "objeto" - as relações entre os seres vivos e o meio físico-químico - já se encontrava em desenvolvimento pelos trabalhos de pesquisadores como Charles Lyell (1797-1875; geólogo escocês), Alexander von Humboldt (1769-1859; naturalista alemão) e Alphonse de Candolle (1806-1893; botânico suiço), - para citar alguns -, e, de outro, reorganizar, em bases evolucionistas, uma Biologia em estado de crise desde $1859^{31}$.

A crise na Biologia é uma crise entre dois grupos de sistemas de pensamento diametralmente opostos: os fixistas, representados basicamente pelos cientistas naturais adeptos do sistema lineano $^{32}$, e os transformistas, representados por poucos cientistas já seduzidos pelas idéias de

\footnotetext{
30 "Em praticamente todos os estudos da história de idéias do século dezenove, Haeckel é raramente, se jamais, separado da tradição geral de cultura européia progressiva, científica, e moderna e seu nome é tido como sinônimo de materialismo, naturalismo, mecanicismo, e obviamente, Darwinismo. Ele é tradicionalmente considerado como um pesquisador que abordou o otimismo, o progresso, o liberalismo, o socialismo, e a oposição infatigável ao poder arbitrário do Estado. Ele invariavelmente é aceito como a encarnação intelectual, dentro da Alemanha, do sentimento de otimismo e segurança, gerado pela ciência e pela industrialização, que difundiram a civilização burguesa antes do cataclismo de 1914.” Tradução Livre.

${ }^{31}$ Ano da publicação de The Origin of Species, de Charles Darwin.

32 O sistema lineano é o "sistema de classificação natural" dos seres vivos, também denominado nomenclatura binomial, nomenclatura binominal ou nomenclatura binária. Ele designa, nas ciências biológicas, o conjunto de normas que regula a atribuição de nomes científicos às espécies de seres vivos. Chama-se binominal porque o nome de cada espécie é formado por duas palavras: o nome do gênero e o restritivo específico, normalmente um adjetivo que qualifica gênero. A utilização do sistema de nomenclatura binomial é um dos pilares da classificação científica dos seres vivos sendo regulada pelos códigos específicos da nomenclatura botânica, zoológica e bacteriológica. Foi primeiramente proposta pelo naturalista suíço Gaspard Bauhin (1560-1624), no século XVII, e formalizada pelo naturalista sueco Carl von Linné (1707-1778) no século seguinte. Os nomes utilizados são em latim, ou numa
} 
Jean-Baptiste Lamarck (1744-1829), Alfred Russel Wallace (1823-1913), Charles Darwin (18091882):

O sistema lineano era extremamente artificial, mas possuía um caráter marcadamente útil para os fins práticos da identificação, e para a reserva e recuperação de informações. A tradição linneana basicamente se ocupou de recoletar, classificar e desenvolver um sistema natural de classificação. Uma classificação era um sistema que permitia ao botânico conhecer as plantas, ou seja, dar-lhes um nome, com rapidez e segurança. A sua preocupação era de ordem prática, no sentido da identificação. Ele enfatizou os aspectos do procedimento taxionômico que pudessem facilitar a identificação. O sistema de Linneu supunha uma concepção estática da natureza, segundo a qual as formas existentes correspondiam às criadas inicialmente. O seu propósito era congruente com a idéia da natureza como obra acabada. Essa visão do supracitado naturalista inseria-se na vertente da história natural que se convencionou chamar de classificatório-descritiva. (MAYR, 1998, p. 206)

Assim como Lineu (1707-1778), vários cientistas naturais do século XIX defendiam a habilidade do sistema lineano em ordenar e categorizar a Natureza, entendida, nessa concepção, como expressão de um princípio racional organizando o mundo natural. Uma vez que Deus não criaria o caos, é preciso nomear os "objetos da Natureza" para que possam ser conhecidos segundo a intenção divina. Assim, o sistema lineano de nomenclatura infere e sistematiza a ordem racional divina, defendendo a invariabilidade das espécies ao longo do tempo.

Apesar de ser apontado como ardente defensor do transformismo, considera-se que toda a pesquisa cientifica realizada por Haeckel indica ser ele um fiel seguidor da tradição lineana no pensamento biológico. Isto poderia explicar o tipo de apropriação teórica que Haeckel e outros filósofos naturais de seu tempo fizeram da visão darwinista da evolução, especialmente no que

versão latinizada da palavra ou palavras que se pretende utilizar. $O$ nome genérico e o epíteto específico devem sempre ser escritos em tipo itálico, ou, na sua indisponibilidade, ser sublinhados, sendo, sempre que possível, seguidos pelo autor ou autores da descrição (em geral, referido como a autoridade). O sistema lineano é utilizado, hoje, para iniciar o processo de classificação dos seres vivos, mas, em seguida, os dados são reexaminados à luz da teoria da evolução e, principalmente, da sistemática filogenética de Willi Hennig, que promoveu a grande revolução do século 20 na taxonomia. Os princípios de Hennig mudaram, pelo menos desde a década de 1970, a maneira de classificar os seres vivos. Para ele, os organismos devem ser classificados de acordo com as suas relações evolutivas e o método para descobrir essas relações é analisar os caracteres ancestrais e os caracteres derivados de cada espécie. (Síntese baseada em: http://www.agencia.fapesp.br/boletim dentro.php?id=8020 e http://pt.wikipedia.org/wiki/Nomenclatura_binomial Acesso em: 28 Abr. 2008) 
tange aos conceitos de adaptação e seleção natural, bem como suas implicações, resultantes da idéia de luta pela sobrevivência, para fundamentar concepções monistas da Natureza.

The idea of evolution which the romantics entertained was, of course, similar to the idea of evolution proposed by Darwin later on, but it was at the same time very different from it. For Darwin, each event in the evolutionary process was a new event. On the other hand, for the romantic nature-philosophers the evolutionary process in a sense, went no place. For them the idea of nature in its fullness existed before the event. It was for this reason that Göethe (whom Haeckel admired as much as Darwin) in his biological work, for example, was constantly looking for archetypal forms in nature. (GASMAN, 1971, xxix). ${ }^{33}$

Essa necessidade de se atender ou acompanhar as tendências filosóficas e literárias da época é uma característica da atuação típica dos pesquisadores do século XIX, pois

(...) o Romantismo alemão é o único que se estrutura como movimento, conscientemente, a partir de uma posição filosófica, o que vai garantir à filosofia um destaque singular dentro do panorama romântico geral. E não apenas o ponto de partida, mas a evolução do movimento, na Alemanha, obedece sempre, primeiramente, a novas exigências de ordem filosófica. Esta presença do pensamento filosófico é uma das características distintivas do Romantismo alemão. (BORHEIM, 2002, p.77)

Além disso, como aponta DeGrood,

(...) with the raise of the Nineteenth Century naturalism, philosophical studies now were to include the ideas of philosophically minded scientists, who set forward their general world views. The representatives of the traditional philosophy were forced to react to these views being advanced by members of the positive sciences. (DeGROOD, 1982, p. 14).

Esse gesto de busca (FLUSSER, 1994) configurou-se, assim, como uma conjunção entre interesses empíricos da Ciência, que desde Descartes, é uma prática baseada no dualismo conceitual, e contribuições teóricas da Filosofia:

In Germany, a group of late-eighteenth- and early-nineteenth-century biologists combined a progressivist view of nature with the romantic thought then current in philosophy and literature to produce the controversial school of Naturphilosophie. (...) Naturphilosophie was the scientific incarnation of German romanticism. Gode von Aesch prescribed the following

\footnotetext{
33 "A idéia de evolução que os românticos tinham em consideração era, naturalmente, semelhante à idéia de evolução que seria proposta por Darwin mais tarde, mas era ao mesmo tempo muito diferente da dele. Para Darwin, cada acontecimento no processo evolutivo era um novo acontecimento. Por outro lado, para os românticos filósofos-da-natureza, o processo evolutivo num sentido, não levava a nenhum lugar. Para eles a idéia de natureza em sua plenitude existida antes do acontecimento. Era por esta razão que Göethe (a quem Haeckel admirou tanto como a Daruin) no seu trabalho biológico, por exemplo, constantemente procurava formas arquetipicas na natureza.". Tradução Livre.
} 
"comprehensive program of all romantic thought: 1 . The establishment of a universal order of metaphysical, not just pragmatic, validity. 2. The determination of a place for man compatible with the faith in a human superionity of more than relative importance. 3. A substantiation of the belief in man's brotherhood and even identity with all of life and thus with all existence." (1941, p. 207). The Naturphilosophen transcribed this program for biology. (GOULD, 1977, p. 35). ${ }^{34}$

O Romantismo, quer seja considerado "uma escola, uma tendência, um fenômeno histórico, um estado de espirito, um evento sócio-cultural" (GUINSBURG, 2002), foi, sem dúvida, um movimento que deixou raizes extensas no pensamento ocidental. Tradicionalmente entendido como resultado da convergência dos efeitos de dois grandes acontecimentos históricos, a Revolução Francesa e a Revolução Industrial (FALBEL, 2002), o periodo romântico produziu idéias às quais se atribui a causa de modificações importantes no panorama politico, econômico e artístico da primeira metade do século XIX, mas que também adentraram o século XX e sobrevivem em pleno século XXI.

Intermediando transformações em sua combinação com a Ciência, especialmente notória no pensamento de filósofos naturais como Schleiermacher, os irmãos Schlegel, Fichte e Schelling, percebe-se que o Romantismo Alemão também deixou rastros no processo de formação do discurso cientifico ao redor do termo ecologia.

No que tange à relação entre Ciência e Filosofia, alguns dos principais elementos característicos do movimento romântico na Alemanha, realmente, traduziam a preocupação de alguns cientistas naturais, como a busca do Todo por meio da nostalgia, o retorno à Natureza e o encontro com o Absoluto, a defesa da imaginação individual como autoridade crítica, que permitiria a liberdade de expressão artística contra as noções clássicas em voga naquela metade de século XIX e contra a racionalização da Natureza proposta pelo Iluminismo:

More than a literary movement, romanticism, in the writings of Schleiermarcher, Fichte, Novalis, Goethe and the Schlegels, was really an expression of German life and feeling. Historically, romanticism arose as a

\footnotetext{
34 "Na Alemanha, um grupo de biólogos, do final do século XVIII e início do século XIX, combinaram a visão progressista da Natureza com o pensamento romântico, então corrente na filosofia e na literatura, para produzir a controversa escola da Naturphilosophie. (...) A Naturphilosophie foi a encarnação científica do romantismo alemão. Gode von Aesch ${ }^{34}$ prescreveu o seguinte "programa geral do pensamento romântico: 1. O estabelecimento de uma ordem universal, não apenas pragmática, mas de força (solidez) metafísica. 2. A determinação de um lugar para o Homem compatível com a fé em uma superioridade humana de maior importância. 3. O consubstanciamento de uma crença da fraternidade do Homem, ou mesmo a identificação com todas as formas de vida e, assim, com toda a existência." (1941, p. 207). Os Naturphilosophen transcreveram esse programa para a biologia.” Tradução Livre.
} 
reaction to the ideas of the Enlightenment and the French Revolution, which had been brought to Germany by the invading armies of France during the revolutionary and Napoleonic periods. German patriotic opposition to the invader became in the realm of ideas opposition to the way of thinking the Enlightenment. The French philosophers had taught that reason was superior to authority, tradition, and human intuition. The romantics, on the other hand, believed that certain truths were outside of the province of reason, and they appealed to man's need for faith and deeper emotional feeling. (...) Despite its call for faith, romanticism, as it developed for the most part of Germany, lacked a religious sense of God, and substituted in place of a deity the worship of nature and the religion and philosophy of pantheism. (...) For the romantics, Nature was in a continual process of becoming. This was expressed at times in the form of a belief in the existence of a Chain of Being in Nature. From inanimate matter all the way up to man and God, there was a unity and interconnectedness. In the course of its development, Nature realized itself in all of its manifold forms. (GASMAN, 1971, p. xvii xix; grifo nosso $)^{35}$

Esse era o quadro cultural no qual a pesquisa e o pensamento haeckeliano se desenvolveram.

Preocupado em dissolver o dualismo no qual a ciência moderna estava mergulhada e que permitia a permanência de um Deus judaico-cristão organizando a Natureza, Haeckel pensa a "destituição" do Cristianismo, como forma religiosa que impedia a aceitação do evolucionismo na Alemanha (e no mundo).

In place of Christianity, Haeckel was prepared to offer the Germans a new religion which was to be derived entirely from science and from the study of nature. He proclaimed to the German in ecstatic, poetic and radically literal terms that 'Alles ist Natur, Natur ist Alles' and that the 'goddess of truth dwells in the temple of nature, in the green woods, on the blue sea, and on the snowy summits of the hills'. The old religious world was characterized by the 'gloom of the cloister' and the 'clouds of incense of the Christian Churches', but the new religion of Monism would find its faith in the "loving study of nature and its laws'. He was expressing his most deeply felt belief when he proposed that Germany could literally save itself by religious devotion to nature and to natural law. (GASMAN, 1971, p. 63)

\footnotetext{
35 "Mais que um movimento literário, o romantismo, nos escritos de Schleiermarcher, Fichte, Novalis, Goethe e os [irmãos] Schlegels, era realmente uma expressão de vida alemã e sentimento. Historicamente, o romantismo surgiu como uma reação às idéias do Iluminismo e da Revolução Francesa, que tinham sido trazidas à Alemanha pelos exércitos invasores da França durante os períodos revolucionário e Napoleônico. A oposição patriótica alemã ao invasor tornou-se no campo das idéias oposição à maneira de pensar o Iluminismo. Os filósofos franceses tinham ensinado que a razão era superior à autoridade, à tradição, e à intuição humanas. Os românticos, por outro lado, acreditaram que certas verdades eram exteriores ao domínio da razão e apelaram para a necessidade que o homem tinha da fé e de sentimentos emotivos mais intensos. (...) Apesar de sua demanda pela fé, o romantismo, como se desenvolveu na maior parte da Alemanha, carecia de um sentido religioso de Deus, e substituiu em lugar de uma divindade, a adoração da natureza e da religião e filosofia do panteísmo. (...) Para os românticos, a Natureza estava num processo ininterrupto de vir a ser (tornar-se). Isto foi expresso, às vezes, na forma de uma crença na existência de uma Cadeia de Existência na Natureza. De matéria completamente inanimada até o Homem e Deus, havia uma unidade e uma interconectividade. No curso de seu desenvolvimento, a Natureza atualizava-se em todas as suas variadas formas.” Tradução Livre.
} 
Ao associar suas idéias monistas na criação do termo ecologia, Haeckel pretendia reorganizar a concepção transformista da vida de maneira que fosse possivel adaptá-la ao sistema lineano de classificação, concebendo uma cadeia de evolução continua que ligava o inanimado ao propriamente vivo, mas cujas transformações já estavam fixadas. Para Haeckel a diversidade de espécies na Natureza estava em relação direta com a noção de todo, de unidade que deve ser reverenciada, e uma escala de transformação dos organismos mais simples ao mais complexos. A saida teórica encontrada para combinar premissas da filosofia natural decorrente do romantismo alemão (Naturphilosophie) e as recém-descobertas características transformistas do materialismo darwinista culminam, em Haeckel, com a proposta de um Monismo que toma emprestado a máxima spinozista "Deus sive natura" ${ }^{36}$.

Tentando desenvolver um monismo baseado nas premissas spinozianas, Haeckel tenta resolver a polêmica ao redor do evolucionismo, proposto por Darwin, e que, basicamente negava o papel determinante de um Deus criador. Mas, ao tentar levar às últimas conseqüências suas concepções monísticas da Natureza, acaba caindo em descrédito por seus pares da época.

A Naturphilosophie e o Monismo Alemão dela resultante impõem premissas que procuram romper com a noção do Deus judaico-cristão, aquele Deus das cidades, do artificial e seguro, que dita as regras da ordem por meio de catástrofes naturais e defende uma Natureza sob controle como o Éden que está à espera daqueles que obedecerem às suas leis. Esse Deus, fruto

\footnotetext{
36 "For many reasons Haeckel did not wish his thought to be characterized as "materialistic". Besides feeling that past "materialisms" were much cruder than his own, he disliked the word's social connotations. As he exclaims: "I have repeatedly before now pointed out that this is an ambiguous party word which conveys absolutely nothing; its apparent opposite, 'spiritualism', could quite easy be substituted for it." Haeckel's monistic naturalism, similarly to Goethe's, has a hylozoistic outcome: "An immaterial living spirit is just as unthinkable as a dead, spiritless material; the two inseparably combined in every atom." Despite Haeckel's statement that his monism could as easy be called "spiritualism" as "materialism", he is definitely a naturalist, that is, he denies the existence of any forces or beings beyond nature. For example, he states unmistakably: "Being convinced of the unity of nature, the fundamental identity of the agencies at work in the inorganic and the organic worlds, I discarded vitalism, teleology, and all hypotheses of a mystic character." (DeGROOD, 1982, p. 25) ["Por muitas razões Haeckel não queria que seu pensamento fosse caracterizado como "materialista". Além de achar que "materialismos" do passado eram muito mais brutos que o seu próprio, antipatizou com as conotações sociais da palavra. Como exclama: "Tenho repetidamente salientado que esta é uma palavra de partido ambíguo que transporta absolutamente nada; seu contrário aparente, "espiritualismo", poderia ser facilmente substituída por ela". O naturalismo monístico do Haeckel, semelhantemente a Göethe, tem um resultado hilozoístico: "Um espírito vivo espiritual é tão impensável como um material inanimado morto; os dois inseparavelmente combinados em cada átomo". Apesar da declaração de Haeckel de que seu monismo podia facilmente ser chamado tanto de "espiritualismo" como "materialismo", ele é definitivamente um naturalista, isto é, ele nega a existência de quaisquer forças ou seres além de natureza. Por exemplo, ele declara inconfundivelmente: "Estando convencido da unidade dea natureza, a identidade fundamental dos agentes no trabalho dos mundos orgânico e inorgânico, eu descartei o vitalismo, a teleologia, e todas s hipóteses de caráter místico.” Tradução Livre].
} 
da oposição entre cidade e deserto, é desmistificado pela Filosofia da Natureza dos Românticos Alemães e pelo Monismo Haeckeliano. Para ambas as visões, o natural é expresso pela riqueza da biodiversidade da floresta, dos oceanos, rios, lagos e montanhas e não mais pelo clima árido, seco e desolador do deserto. No ambiente do deserto há o pecado e a dor e a única maneira de sobreviver e de alcançar a paz é apartando-se de tudo o que é natural. A imagem de Natureza como perigo e privação é, assim, substituida pela imagem de Natureza como abundância, tranqüilidade, possibilidade de redenção e liberdade.

Desenvolvida pari passu com uma teoria poética da origem do mito e da linguagem na alma de cada povo, a atividade mitogênica do Romantismo ligou o sentido dramático do tempo histórico, caudal propulsivo transformando as nações, ao crescimento orgânico e à floração espontânea da natureza, que circunscreveria, como último limite de uma consciência retrospectiva dirigida a etapas remotas do passado, o estado primigênio do Homem, onde o natural e o cultural se transpassam e se confundem. (NUNES, 2002, p.70)

À necessidade de uma Natureza sob controle, porque representava o deserto e as privações da vida nômade, contrói-se uma representação de Natureza com os mesmos direitos de existência que os do Homem, pois é entendida como parte dele. E é nela que o Deus habita. Se existe um Éden, ele está materializado na Terra sob a forma das inúmeras paisagens naturais. Uma nova forma de mistica se organiza na escritura cientifica e filosófica que fundamenta essa visão de Natureza, a ponto de Gasman (1971) 37 considerar o Monismo Alemão uma nova religião que buscava fortalecer e institucionalizar uma forma de materialismo que pudesse ajustar a crença num ser supremo às idéias evolucionistas por meio da apropriação, muitas vezes, imprecisa, de diversas noções darwinistas.

Thus, for the [Eighteenth Century German] Monists, evolutionary religion meant the final abandonment of Christianity and the total immersion of

\footnotetext{
${ }^{37}$ Gasman (1971) também considera que: "A close investigation of the major ideas of Haeckel and his followers reveals a romantic rather than a materialistic approach to biology and a striking affinity not with liberalism or socialism but with the ideology of National Socialism. (...) the content of the writings of Haeckel and the ideas of his followers - their general political, philosophical, scientific, and social orientation - were proto-Nazi in character, and that the Darwinist movement which he created, one of the most powerful forces in nineteenth- and twentieth-century German intellectual history, may be fully understood as a prelude to the doctrine of National Socialism." (GASMAN, 1971, p. xiv) ["Uma investigação próxima das idéias importantes de Haeckel e de seus seguidores revela uma abordagem romântico mais que materialista da biologia e uma afinidade chamativa não com o liberalismo nem o socialismo mas com a ideologia do Socialismo Nacional. (...) o conteúdo dos escritos de Haeckel e as idéias dos seus seguidores - sua orientação geral política, filosófica, científica, e social - eram protonazistas em caráter, e o movimento de Darwinista que ele criou, uma das forças mais poderosas nos séculos dezenove e vinte na história intelectual alemã, plenamente pode ser entendida como um prelúdio à doutrina de Socialismo Nacional." Tradução Livre.]
} 
oneself in nature'. The 'modern individual', they contended, desires to be 'in and of nature' and wants to feel its pulse because he is blood of its blood'. In nature alone man finds his roots. 'The more fundamentally man contemplates nature, all the more deep and exalted is the feeling of interrelatedness with all of organic nature, the more he feels that nature is homeland and that it can become the basis for his own life.' It is for this reason that biology had to become the queen of modern science. It is from biology that man learns the most about the 'unity of all organic life' and the truth that 'all organisms, from the simplest amoebae and bacteria, to plants and animals, all the way up to man, are similar and equal to each other because they follow the same general laws, have the same characteristics, and are blood relations of each other.' Furthermore, one can find real peace and contentment only in nature. (...) It is then that he perceives how the forces of nature 'control my life just as they do plants and animals'. Since the observation of nature produces such revelations, it is essentially a religious activity, and the Monists accordingly cautioned that a person who contemplates nature assumes a great responsibility. (...) And specially the evolution of man had to be studied in a religious spirit: 'The idea of the evolution of mankind from the animal kingdom not only does not fill us with shame, but rather awakens in us a deep feeling of awe, wonder, and contemplation before the development of nature of which we are part.' (GASMAN, 1971, p.66-67; grifos nossos).

Valores éticos similares são expressos e defendidos pelo Transcendentalismo Americano, que também conclama a unidade da Natureza e a importância do Homem como parte dela. O papel do Transcendentalismo Americano, entretanto, será maior no desenvolvimento do movimento ambientalista enquanto movimento político contracultural, devido, especialmente, à importância de dois escritos de Henry David Thoreau (1817-1862): Walden (1854) e Desobediência Civil (1859). Nelas, ao mesmo tempo em que defende a vida simples em contato com a Natureza, Thoreau protesta contra a escravidão e a guerra mexicana. Para Thoreau existe uma valoração positivada na Natureza, entendida como o ambiente natural, ou a vida no campo, o contato com a rudeza e a simplicidade da paisagem natural, em contraste à vida na cidade, ao consumo e ao trabalho em função de interesses que não honram a "natureza" humana, mas a corrompem. Além disso, existe, no transcendentalismo norte-americano, a reivindicação do direito de existência de todas as coisas naturais - de insetos e aves até montanhas, pedras e paisagens.

Na história de cada individuo, e também da raça, há um período em que os caçadores são considerados os homens por excelência, como os chamavam os algonquinos. Não podemos deixar de ter pena do garoto que nunca disparou um revólver; ele não se tornou mais humano, ao passo que sua educação foi tristemente negligenciada. Eis a minha resposta a respeito desses jovens que tinham inclinação pela caça, confiando que breve haveriam de superá-la. Nenhum ser humano, passada a fase de estouvamento da infância, irá 
irresponsavelmente assassinar qualquer criatura, que valoriza sua vida pelo mesmo titulo de posse que ele. A lebre em sua hora extrema chora que nem uma criancinha. Previno-vos, mães, que minhas simpatias nem sempre fazem as distinções filantrópicas usuais. (THOREAU, 2001, p. 208-209; itálico do autor).

Essa visão transcendentalista de mundo produz, ainda hoje, efeitos sobre a sociedade contemporânea, visto que várias organizações ambientalistas são voltadas aos direitos dos animais, das plantas, do planeta entendido como organismo Uno. A concepção de que o natural tem de ser protegido de agressões quaisquer provenientes do Homem e a valoração dos direitos civis que devem ser, então, estendidos ao ambiente natural ${ }^{38}$.

Assim, não é de se estranhar a publicação, em 1864 (dois anos antes da "invenção" da palavra ecologia por Haeckel) da obra antológica de George Perkins Marsh (1801-1882), naturalista britânico, na qual a visão negativa da presença do Homem na Terra/Natureza decorre do uso 'inescrupuloso' dos recursos naturais. Intitulada Man and Nature, or Physical Geography as Modified by Human Action, o livro é considerado por muitos filósofos e historiadores da ciência...

... um clássico no que se refere ao problema da influência do homem no mundo e na harmonia que deve existir entre ele e seu habitat. (...) Os conceitos que devem presidir à conservação da natureza no mundo moderno foram todos expostos nessa obra fundamental. (DORST, 1973, p. 91).

A obra de Marsh (1864) marca o início da preocupação com o ambiente natural, entendido como espaço a ser protegido da ameaça do urbano, invertendo, mais uma vez, a relação de forças entre a cidade e a paisagem, no que tange ao maniqueísmo típico dos mitos arcaicos judaico-cristão. Agora é a cidade que representa o lugar da maldade, da corrupção da alma, do irracional, e o sagrado, como lugar do natural, está em risco.

Em 1908, essa versão de valores encontra apoio nas declarações do, então, Presidente Theodore Roosevelt (1858-1919), durante a Conferência sobre a Conservação dos Recursos Naturais:

Enriquecemo-nos pela utilização pródiga dos nossos recursos naturais e podemos, com razão, orgulhar-nos do nosso progresso. Chegou, porém, o

\footnotetext{
38 O pensamento quase "anarquista" expresso pelo ensaio "Desobediência Civil" (1849) inspirou não apenas Gandhi, mas grupos ambientalistas tão diversos quanto o Greenpeace, o Sea Shephard, e a PETA (People for the Ethical Treatment of Animals). Esse aspecto cultural que marca o aparecimento do ambientalismo moderno como formação discursiva é, muitas vezes, ignorado ou esquecido, tanto por jornalistas, quanto por vários estudos sociológicos relativos ao movimento.
} 
momento de refletirmos seriamente sobre o que acontecerá quando as nossas florestas tiverem desaparecido, quando o carvão, o ferro e o petróleo se esgotarem, quando o solo estiver mais empobrecido ainda, levado para os rios, poluindo as suas águas, desnudando os campos e dificultando a navegação. (apud DORST, 1973, p. 1)

Assim, em 1935, quando Arthur George Tansley (1871-1955), ecólogo de plantas inglês, introduz a palavra e o conceito de ecossistema na apresentação de seu artigo The Use and Abuse of Vegetational Concepts and Terms na revista cientifica Ecology, o campo politico que defendia a importância da conservação ou proteção do ambiente natural já está sedimentado. A combinação entre o viés político e o viés cientifico da formação discursiva sobre meio ambiente será fundamental para a expansão do discurso ecológico como discurso politico contracultural na década de 60, nos Estados Unidos, e para a institucionalização da ecologia como ciência que estruturará tal discurso.

\section{3:: Formação discursiva e o pensamento ecológico contemporâneo ::}

A preocupação com o espaço natural organiza-se, então, como formação discursiva de um sistema de pensamento sobre a ciência ecológica e sobre a necessidade de se proteger recursos naturais.

De um lado, a necessidade de se garantir a permanência de um conjunto de condições gerais físicas, químicas, biológicas, políticas, sociais e econômicas necessárias à sobrevivência humana, e, também, de se aderir a uma forma de protesto generalizado contra processos degenerativos (guerras, poluição, desigualdade social e econômica, sigilo de informações) do sistema políticoeconômico dominante, no período da Guerra Fria (1947-1991) deflagra os discursos políticos sobre a conservação do mundo natural. De outro lado e concomitantemente, estrutura-se cientificamente um saber "verdadeiro": a ciência dos ecossistemas.

O conceito de ecossistema tem influência direta de duas outras noções, também, extremamente caras à formação discursiva que engendra significações sobre tudo que se refere ao cuidado com o planeta Terra: 1) A noção de unidade da Natureza advinda do holismo (noção similar à idéia de 
monismo), definida por Jan Christiaan Smuts (1870-1950), em 1926³. 2) As várias noções de sistema, abordadas por Karl Ludwig von Bertalanffy (1901-1972), em 1952 .

Tansley apresentou sua nova palavra ao mundo da seguinte maneira:

But the more fundamental conception is, as it seems to me, the whole system (in the sense of physics), including not only the organism-complex, but also the whole of physical factors forming what we call the environment of the biome - the habitat factors in the widest sense. It is the systems so formed which, from the point of view of the ecologist, are the basic units of nature on the face of the earth. These ecosystems, as we may call them, are of the most various kinds and sizes. They form one category of the multitudinous physical systems of the universe, which range from the universe as a whole down to the atom. (TANSLEY, 1935, p.299 apud GOLLEY, 1993, p. 8; itálico de

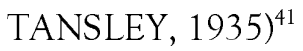

Ecosssistema, como conceito novo, participa, antes, de uma formação discursiva dominada pela escritura cientifica já estabelecida em torno das comunidades vegetais e das investigações biogeográficas, cujas pesquisas tinham seus resultados discutidos entre pesquisadores norteamericanos e ingleses, durante o final do século XIX e início do Século XX.

Golley (1993) afirma que o desenvolvimento do conceito de ecossistema só podia ser possivel nos Estados Unidos. Para ele, a história do conceito de ecossistema é uma história americana, devido às condições cientificas ali existentes.

(...) the conditions for growth existed only in the United States. The most important factor was the second world war, which interrupted ecological work worldwide. After the war the United States experienced a period of rapid development, which included scientific activity in ecology. In contrast, Europe and Japan were preoccupied with reconstruction, a reexamination of the principles of government, and the recovery of normal life. (GOLLEY, 1990, p. 2)

\footnotetext{
${ }^{39}$ SMUTS, Jan Christiaan. Holism and Evolution. New York: Macmillan, 1926. apud GOLLEY, 1993, p.

${ }^{40}$ BERTALANFFY, Karl Ludwig von. Problems of Life: Na Evaluation of Modern Biological and Scientific Thought. New York:Harper Torchbooks, 1952.

41 "Mas a concepção mais fundamental é, como me parece, o sistema inteiro (no sentido de física), incluindo não apenas o organismo-complexo, mas também o total de fatores físicos que formam o que nós chamamos de ambiente do bioma - os fatores de habitat no sentido mais amplo. São os sistemas assim formados que, do ponto de vista do ecologista, são as unidades básicas da natureza na da Terra. Estes ecossistemas, como podemos chamá-los, são das mais variados tipos e tamanhos. Formam uma categoria do múltiplos sistemas físicos do universo, que variam do universo como um todo até o menor dos átomos.” Tradução Livre.
} 
O autor destaca que muitos pesquisadores importantes para o início da fundamentação da Ecologia como campo científico, haviam morrido ou abandonado seus estudos devido à guerra. Além disso, e, talvez mais relevante, era o fato de que as pesquisas sobre ecossistemas estavam muito próximas das teorias organicistas ecológicas, biológicas e sociais do pré-guerra, utilizadas pelos nazistas. A popularidade dos estudos ecológicos estava, assim, bastante baixa na Europa, diferente dos EUA:

In America, however, the ecosystem concept appeared to be modern and up to date. It concerned systems, involved information theory, and used computers and modeling. In short, it was a machine theory applied to nature. The concept promised an understanding of complex systems and explicity promised to show Americans could manage their environment through an understanding of the structure and function of ecological systems and by predicting their responses to disturbance. Further, it extended the holistic concept into the modern, postwar environment. (GOLLEY, 1990, p. 2; grifo nosso $)^{42}$

O desenvolvimento da noção de ecossistema, no pós-guerra, coincide com uma série de eventos relacionados à divulgação da pesquisa ecológica nos Estados Unidos, que dará início aos primórdios do movimento ambientalista. Este termo inclui a noção relacional de orgânicoinorgânico, inerente à Natureza por ser, justamente, uma representação do Todo tomado como sistema, tal qual o termo tomou empréstimo das concepções que o fundaram: o holismo e a teoria de sistemas.

Ecossistema, como conceito, permitiu o advento de um nivel mais complexo da ciência ecológica - a Teoria dos Ecossistemas. Esta sim, será, a "marca registrada" desse materialismo empírico e o seu estabelecimento como ciência que se centra no estudo das transformações dentro de sistemas fechados, concebidos como modelos puros e ideais do comportamento do meio natural, no nível das transformações microscópicas, de concentração de gradientes dos componentes orgânicos e inorgânicos, sem considerar a intromissão ou as alterações das atividades antrópicas. Não se pensava, então, que a atividade antrópica poderia causar efeitos visiveis ou mensuráveis no ambiente natural. Os modelos eram criados a partir de lagos, lagoas,

\footnotetext{
42 "Na América, no entanto, o conceito de ecossistema apareceu ser moderno e até atual. Envolvia sistemas, teoria da informação, e utilizava computadores e modelagem matemática. Em resumo, era uma teoria de máquina aplicada à natureza. $\mathrm{O}$ conceito prometeu um entendimento dos sistemas complexos e explicitamente prometeu mostrar aos americanos que podiam administrar seu ambiente por um entendimento da estrutura e da função dos sistemas ecológicos e por predizer suas respostas a perturbação. Mais ainda, ampliou o conceito holístico para o ambiente moderno do pós-guerra.” Tradução Livre
} 
recortes da realidade concreta, a partir do qual os comportamentos eram generalizados para a biocenose.

De acordo com Golley (1993), o desenvolvimento e a rápida aceitação da noção de ecossistema e da importância da ecologia, nos Estados Unidos, tiveram uma relação direta com as condições culturais do pós-guerra:

The whole played a key role in the intellectual development of ecology through the monoclimax and successional paradigms of Frederic Clements, the famous plant ecologist of the Carnegie Institution of Washington. The concept of holism had wider cultural significance. It postulated the existence of a complex entity, larger than humans or human society, which was selforganized and self-regulating. In one sense, involved the extension of Godlike or parental properties to nature. Most significantly, it provided the individual faced with the complications and difficulties of daily life the notion that somewhere out there, there was ultimate order, balance, equilibrium, and a rational and logical system of relations. This mixture of ideas was carried forward past the second world war period by the generation that had fought the war, and it dominated the immediate postwar years. The ecosystem concept fit into it, giving guidance to ecological scientists and avoiding dissonance with the overall culture. (GOLLEY, 1993, p. 3; grifo nosso $)^{43}$

A partir daí, o processo sócio-histórico de transformação de sistemas de pensamento e o deslocamento para uma nova interpretação de antigas noções (isto é, a instauração de uma nova verdade legitimada por um saber) é notório.

O surgimento do movimento ambientalista nos Estados Unidos tem assim dois elementos importantes: os valores do transcendentalismo e o conceito de ecossistema.

Durante a década de 50, as noções relativas ao funcionamento e importância da manutenção dos ecossistemas, nos Estados Unidos, começa a ser lentamente divulgado pelos veículos de

\footnotetext{
43 "A noção de Todo teve um papel-chave no desenvolvimento intelectual da ecologia por meio do paradigma do monoclimax e do sucessional de Frederic Clements, o famoso ecologista de plantas da Instituição Carnegie de Washington. $\mathrm{O}$ conceito de holismo teve importância cultural mais ampla. Postulou a existência de uma entidade complexa, maior que os seres humanos ou a sociedade humana, que era auto-organizada e auto-regulada. Em um sentido, envolveu a extensão de semelhança com Deus ou propriedades paternais relativas atribuídas à natureza. $O$ mais significativo, foi ter fornecido ao cidadão, que enfrentava as complicações e dificuldades de vida diária, a noção de que, em algum lugar, lá fora, havia ordem final, harmonia, equilíbrio, e um sistema racional e lógico de relações. Esta mistura de idéias foi transportada após o período da Segunda Guerra Mundial pela geração que tinha lutado a guerra, e dominou os anos pós-guerra imediatos. O conceito de ecossistema adaptou-se a ele, dando direção a cientistas ecológicos e evitou dissonância com a cultura total.” Tradução Livre.
} 
informação. A legitimação desse conhecimento cientifico como fundamento para decisões politicas se dará pela institucionalização dos espaços discursivos que elaboram relatórios técnicos para o PNUMA (Programa das Nações Unidas para o Meio Ambiente) e organizam as Grandes Convenções sobre Meio Ambiente.

O ambientalismo como movimento social de contracultura, foi caracterizado pelos valores do transcendentalismo norte-americano, e tinha no movimento pacifista hippie, sua principal força politica. Gradativamente o movimento perde esse aspecto definitório e passa a se organizar como biopolítica, à medida que empresas privadas e governos nacionais começam a prever ou se antecipar as demandas ambientalistas, introduzindo medidas mitigatórias nos processos deletérios aos sistemas naturais, refletindo a apropriação do discurso contracultural inicial pelo sistema econômico dominante.

Em vistas de um sistema capitalista que prioriza o controle de pragas no agronegócio, pelo uso de substâncias químicas altamente contaminantes e prejudiciais aos seres vivos ${ }^{44}$, Rachel Carson $^{45}$ se manifesta. Organizado em 1962, dois anos antes da morte da autora, o livro Silent Spring foca especificamente as conseqüências desastrosas do uso descontrolado de $\mathrm{DDT}^{46}$ e de outros pesticidas organoclorados na agricultura norte-americana e que levou à redução drástica de espécies animais - principalmente aves, anfibios e pequenos mamiferos. Parte do livro fora antes publicado como uma série de artigos na revista New Yorker.

Trazendo inúmeras fontes sobre as primeiras 'questões ecológicas', por se tratar de problemáticas em que basicamente pesquisadores da ciência ecológica começavam a observar nos ecossistemas alterações graves no "equilibrio" dos fluxos de matérias e energia, o livro de

\footnotetext{
${ }^{44} \mathrm{O}$ uso intensivo de agrotóxicos na chamada "Revolução Verde" está associado à estratégia e tática de guerra do governo norte-americano nas Guerras da Coréia e do Vietnã e teve o apoio da indústria química norte-americana, que desenvolveu os mais diferentes tipos de substâncias químicas tóxicas para uso nos combates no oriente e na agricultura doméstica dos estados Unidos.

${ }^{45}$ CARSON, Rachel. (1962). Primavera silenciosa. São Paulo: Melhoramentos, 1969.

${ }^{46}$ A década de 50 (no século XX) reflete o auge do uso dos pesticidas organoclorados. Segundo Acot (1990, p. 106), foi "a descoberta dos poderes inseticidas do DDT e de sua longa descendência de pesticidas organoclorados" que desencadeou "a irrupção em grande escala da luta química em ecologia." Esta, por sua vez, "desempenhou, na história do controle biológico, um papel complexo, pois contraditório” uma vez que propunha o combate a pragas pelo uso de substâncias químicas que se acumulavam nos fluxos de matéria e energia tanto dos ambientes agricultáveis quanto dos ecossistemas naturais.
} 
Carson relata, de forma bem documentada, as constatações cientificas de que o Homem poderia realmente intervir negativamente no ambiente natural de forma drástica. Isso levava os pesquisadores a acreditar que haveria conseqüências danosas à saúde humana também. Essa correlação entre causa-efeito, no campo da ciência ecológica, levou a outras correlações, que extrapolaram o campo do saber ecológico no que tange aos efeitos concretos e aos de significação e sentido. Surge, assim, a ecologia política. Daí, Golley (1993) afirmar que a ecologia politica, propriamente dita, teve início, exatamente, na década de 50:

By the end of the 1950s, however, the conflicts within American society began to intrude upon ecological scientists, no matter how deeply they hid within their ivory towers. Rachel Carson ignited the environmental movement through her book on the effects of pesticides. Ecologists were asked to testify on both sides of the debates that followed. Environmentalists seized upon the ecosystem concept as a way to maintain their faith in holism. The use of pesticides by humans disturbed in a fundamental way the natural order of the world. The issue was a moral one. The ecosystem, and sometimes, "the ecology", were being disturbed, and humans were in danger of destroying the system upon which they lived. (GOLLEY, 1993, p. 3; grifo nosso) ${ }^{47}$

A indústria química norte-americana, insatisfeita com as denúncias cientificas que a acusavam de irresponsabilidade, perseguiu Carson, tentando desacreditar suas declarações. Mas, da vinculação de seu discurso ecológico com o discurso do direito civil (uma vez que seus estudos relacionavam claramente o uso do DDT com a morte de centenas de animais que tinham direito à vida tanto quanto os homens, como já defendia Thoreau), nasce a enunciação de um direito específico e crucial: o da qualidade do meio ambiente para garantir a vida presente e futura. Essa idéia fez crescer a atuação dos governos e da própria indústria química em relação ao uso indiscriminado de pesticidas organoclorados. Contra a Revolução Verde do agronegócio, há a insurgência de outra "revolução verde", liderada pelos ecólogos, instados a revelar o resultado de suas pesquisas sobre a degradação de ecossistemas naturais.

\footnotetext{
47 "Por volta dos anos 50, porém, os conflitos dentro da sociedade americana começaram a invadir as salas de pesquisa dos ecólogos, não importando quão escondidos estavam em suas torres de marfim. Rachel Carson iniciou o movimento ambientalista com seu livro sobre os efeitos dos pesticidas e os ecólogos foram solicitados a testemunhar de ambos os lados do debate que se seguiu. Ambientalistas aproveitavam-se do conceito de ecossistema como uma forma de manter sua fé no holismo. $O$ uso de pesticidas pelos seres humanos perturbou de maneira fundamental a ordem natural do mundo. $O$ assunto passou a ser uma questão moral. $O$ ecossistema, e às vezes "a ecologia", estavam sendo perturbados e os homens estavam em perigo por destruir um sistema do qual dependiam.” Tradução Livre.
} 
O processo de entretecimento dessas "verdades" ecológicas, a ciência dos ecosssistemas e a necessidade de proteção do ambiente natural, parece se dar pela "denúncia científica": as verdades de um saber ecológico começam a adentrar o espaço do politico e do público, com maior intensidade, organizando uma formação discursiva que fará parte, mais tarde, de uma biopolitica global: uma proposta de regulamentação para que a população humana do planeta possa "dividir" e usufruir, igualitariamente, dos recursos naturais planetários, garantindo, assim, sua saúde e a saúde das gerações futuras.

$\mathrm{Na}$ década de 60, os efeitos danosos do uso da energia nuclear na Segunda Guerra Mundial começaram a ser divulgados pela imprensa, municiada, também, por pesquisas cientificas. Surge um "casamento" entre Jornalismo e Ciência, nunca antes experimentado, e que coincide, ainda, com a turbulência dos movimentos sociais de juventude da década de 60 , que demandam maior acesso público à informação de modo geral e, inclusive, aos estudos sobre impactos à natureza por organoclorados e pela energia nuclear ${ }^{48}$.

Ao entrarmos na década de 70, a palavra ecologia torna-se corrente para o grande público, período que marca o início da divulgação de acidentes [denominados 'ecológicos'] noticiados pela grande mídia. O impacto visual e informativo dos acidentes de Three Miles Island ${ }^{49}$, Exxon Valde ${ }^{50}$, Bhopal ${ }^{51}$ e Chernoby $l^{52}$ transformaram radicalmente a visão que se fazia do progresso, do

\footnotetext{
${ }^{48}$ Nas décadas de 60 e 70 surgem o Sierra Club, o WWF e o Greenpeace, algumas das principais organizações ambientalistas da contemporaneidade. O Greenpeace, especialmente, tem desde sua origem, a marca dos protestos da contracultura dos anos 60 e a clara adesão ao transcendentalismo de Thoreau, ao defender abertamente a desobediência civil em suas ações. Aliás, nesse caso, é curioso notar como a contracultura dos anos 60 se opõe ao consumo, ao sedentarismo e aos valores da classe média dominante, mas percebe e utiliza os veículos de informação para se fazer ouvir.

49 Às 4 da manhã do dia 28 de março de 1979, um reator da termelétrica nuclear de Three Mile Island, próxima a Harrisburg, Pennsylvania repentinamente superaqueceu, liberando gases radioativos. Durante uma semana tensa, cientistas agitaram-se para prevenir o pesadelo de um colapso do reator, o governo apressou-se para acalmar a população, e centenas de residentes refugiaram-se em abrigos de emergência. Falhas de equipamento, erro humano e falta de sorte teriam conspirado para criar o pior acidente nuclear da história dos Estados Unidos. Disponível em http://www.pbs.org/wgbh/amex/three/ Acesso em: 04 Dez. 2005.

${ }^{50}$ No dia 24 de março de 1989, logo após a meia-noite, o petroleiro Exxon Valdez desviou-se da rota em Prince William Sound (PWS), Alaska, para evitar icebergs e encalhou em Bligh Reef, levando ao vazamento de 37.000 toneladas de óleo bruto em Alaska North Slope (ANS). Essa quantia era aproximadamente 20\% das 180.000 toneladas de óleo que o navio transportava quando encalhou no recife. Disponível em http://www.valdezscience.com Acesso em: 04 Dez. 2005.

${ }^{51} \mathrm{Na}$ madrugada do dia 3 de dezembro de 1984, 27 toneladas de metil isocianato, cianeto de hidrogênio, monometil de amina e outros gases letais vazaram da fábrica de produção de pesticidas organoclorados da Union Carbide Corporation, em Bhopal, Índia. Oito mil pessoas morreram na primeira semana após o acidente. Cem mil
} 
desenvolvimento tecnológico e do potencial de felicidade, igualdade e fraternidade deles advindos.

É nesse periodo que o fazer jornalístico empresta outra significação à noção de ecossistema e confunde o logocentrismo científico que deveria embasá-la:

John Algeo (1988) ${ }^{53}$ describes numbers of eco- words that have become current in American literature and speech. These words include ecotage, ecofix, ecopornography, ecodisaster, ecodefense, ecofact, ecomenu, econote, and so on. The usage almost implies some connection with environment. Thus, ecodisaster would mean a serious event in which a disaster occurred in the environment, causing environmental disturbance. The use of eco-for environment comes from misuse of ecology as a synonym for environment by the American media beginning in the late 1960s. Apparently, the shorter word ecology fit the column width of a printed page better than the longer word environment. Newspapers especially were impervious to repeated attempts by ecologists to correct this misusage. It is, now, fixed in the language. (GOLLEY, 1993, p. 221; itálicos do autor $)^{54}$

A nova causa organiza-se como discurso político que é proferido e reproduzido pelos veículos de informação. A relação de dependência que o Homem tem da natureza começa a ser significada como uma relação de causa-efeito que pode ter resultados globais devido ao papel democratizante da divulgação de discursos atribuido à mídia:

Quanto à ecologia, esta se apresentou, inicialmente, tanto como uma disciplina cientifica especializada nos estudos de ecossistemas naturais, quanto como um fenômeno marginal cuja sensibilidade tinha como eixo a natureza, a

habitantes da área atingida possuem lesões permanentes. Até 2003, mais oito mil pessoas haviam morrido em decorrência dos efeitos da contaminação. Disponível em http://www.bhopal.net/ Acesso em: 04 Dez. 2005.

${ }^{52}$ Em 26 de abril de 1986, às 1:23:44, o reactor n. 4 da Usina Nuclear de Chernobyl explodiu, durante um teste das turbinas. A relaização do teste dependia do desligamento dos sistemas de segurança da planta, mas o desligamento de emergência do reator também nõa funcionou, inexplicadamente. Assim, a radiação foi violentamente liberada - 100 vezes mais do que a que resultou do lançamento das bombas de hidrogênio sobre Hiroshima and Nagasaki. Dsiponivel em: http://www.chernobyl.info/index.php Acesso em: 29 Abr.2006.

${ }^{53}$ Algeo, John. Among the new words. American Speech. 63:345-52. 1988. apud GOLLEY, 1993, p. 221.

54 "John Algeo (1988) descreve inúmeras palavras com sufixo 'eco-' que têm sido correntes na literatura e no discurso norte-americanos. Estas palavras incluem ecotage, ecofix, ecopornography, ecodisaster, ecodefense, ecofact, ecomenu, econote, e assim por diante. $O$ uso quase sempre implica em alguma conexão com o ambiente natural. Dessa forma, ecodisaster significaria um evento sério no qual um desastre ocorreria no ambiente natural, causando distúrbio ambiental. A utilização do prefixo 'eco-' como referência a ambiente natural advém de um equívoco: a tomada do vocábulo ecologia como sinônimo de ambiente natural pela mídia norte-americana, no início dos anos 60. Aparentemente, é que, por ser menor, a palavra ecology cabia melhor que a palavra environment na largura da coluna dos jornais. Os jorna is impressos, principalmente, foram impérvios às repetidas tentativas dos ecólogos para corrigir esse uso equivocado. Este significado está, agora, fixado na língua.” Tradução Livre. 
defesa do meio ambiente e das espécies vivas ameaçadas de extinção. Durante muito tempo, este fenômeno foi sentido entre a classe política como regressivo, reduzindo-se a um "retorno à natureza" em detrimento dos problemas humanos. Aliás, a ecologia só deixou de ser assunto de alguns poucos círculos a partir do momento em que as agressões ao meio ambiente, como a poluição atmosférica, a destruição das florestas, a ameaça à camada de ozônio, os acidentes nucleares, apareceram para a opinião pública como importantes atentados à sobrevivência da humanidade. Nos anos 80, uma reviravolta nas mídias de massa, já então sensibilizadas por estas questões, contribuiu para o aumento do público dos movimentos de ecologia politica. (GUATTARI, 2000, p. 15)

É seguindo essa tendência que surgem, a partir da década de 70, os primeiros grandes documentos e fóruns internacionais para a discussão da questão dos impactos humanos no meio ambiente: o Clube de Roma, o PNUMA, a Rio 92 e as várias convenções e tratados internacionais voltados para cada um dos temas ambientais - o Protocolo de Montreal, o Protocolo de Kyoto, a Convenção de Londres, o Comitê de Pesca da Organização das Nações Unidas para a Agricultura e a Alimentação, a Convenção sobre a Biodiversidade, a Convenção da Basiléia, a Convenção sobre Comércio Internacional de Espécies da Fauna e da Flora Ameaçadas de Extinção - CITES, a Comissão Baleeira Internacional - CBI, o Tratado Antártico, a Convenção de Estocolmo sobre Poluentes Orgânicos Persistentes -, "marcam a produção de um discurso ecológico a partir de um determinado lugar de representação política: o espaço público internacional" (SILVA, 1995):

A realização e a elaboração, através da ONU, de Conferências e documentos que remetem à questão ambiental, é [sic] representativa de um processo de formalização/institucionalização desta questão. Neste espaço político significado inicialmente através de um discurso de desenvolvimento que exclui a questão ecológica -, um discurso de meio ambiente e desenvolvimento se constitui, no sentido de uma universalização para os sentidos da ecologia. (...) Através de uma determinada "visualização" dos prejuízos ecológicos, o sentido universal trabalha então a questão ambiental de modo a lhe produzir uma legitimidade e uma legalidade: uma ética ambiental e um direito ambiental são, aí, simultaneamente constituídos. (SILVA, 1995, p.7-8)

Esses fóruns institucionalizam o discurso ecológico e o legitimam porque levam o tema às instituições sociais que, agora, são responsáveis por agir em nome da população - o lugar "oficial" de onde o discurso ecológico passa, então, a ser proferido. Todas essas características sociais, históricas, culturais e semânticas constroem uma complexidade discursiva ímpar que se expressa nos produtos de comunicação: 
O capitalismo pós-industrial que, de minha parte, prefiro qualificar como Capitalismo Mundial Integrado (CMI) tende, cada vez mais, a descentrar seus focos de poder das estruturas de produção de bens e de serviços para as estruturas produtoras de signos, de sintaxe e de subjetividade, por intermédio, especialmente, do controle que exerce sobre a mídia, a publicidade, as sondagens etc. (GUATTARI, 1990, p. 31).

No contexto contemporâneo, o discurso ecológico organiza o gesto de busca e a biopolitica por meio de um modelo de desenvolvimento cientifico, econômico, social e cultural que inclua a "realidade ambiental", propiciando um novo conceito de "qualidade de vida". O gesto de busca e a biopolitica significam a possibilidade de que o sistema de produção capitalista venha a ser um modelo economicamente viável, ambientalmente correto e socialmente justo para produzir uma relação Homem-Natureza supostamente “equilibrada”: a noção de que a questão ambiental não é puramente uma questão do ecossistema, mas o resultado da interação entre este e as atividades humanas.

Entretanto, a Ciência ecológica ou ecossistêmica indica que o grau de produção e de consumo (em termos de matéria e de energia) motivado pelo desenvolvimento de novas tecnologias de apropriação dos recursos naturais, contradiz a realidade dos ecossistemas que não têm sido mais capazes de manter seu equilibrio natural. Torna-se possivel estabelecer que o ambiente natural não pode ser reconhecido apenas como provedor de alimento, ar e água para a humanidade e hábil depurador das toneladas de residuos estranhos nele lançados. $\mathrm{O}$ modo como nosso sistema produtivo se apropria da Natureza poderá levar ao fracasso a própria sociedade que sustenta, caso não sejamos bem sucedidos no estabelecimento de uma reestruturação ampla do modelo atual de desenvolvimento.

Tal crença no poder da Ciência, típica da modernidade, não consegue cumprir a promessa de "liberdade da escassez, da necessidade e da arbitrariedade das calamidades naturais" (HARVEY, 1993, p. 23). Qualquer leitura superficial dos noticiários televisivos e do jornalismo impresso ou virtual mostra, claramente, o fracasso dessa empreitada filosófica. De enchentes em rios e córregos paulistanos, passando pelos vendavais e tufões em Santa Catarina, 'linguas negras' no Rio de Janeiro, até terremotos no Oriente Médio e tsunamis na Ásia, a crença na onipotência tecno-cientifica não foi apenas colocada à prova, mas evidenciada, também no campo da ecologia, como mais um mito do racionalismo moderno. 
O pensamento ecológico estabecece-se, assim, por meio da fixação de um vocábulo, em todas as linguas capazes de traduzir ecology, reduzindo a complexidade inerente ao discurso cientifico e à escritura que o constituiu:

A ecologia, por exemplo, nunca é "ecologia como tal", mas está sempre encadeada numa série específica de equivalências: pode ser conservadora (defendendo o retorno a comunidades rurais equilibradas com estilos tradicionais de vida), estatal (só uma regulamentação estatal forte é capaz de nos salvar da catástrofe iminente), socialista (a causa primordial dos problemas ecológicos reside na exploração capitalista dos recursos naturais, voltada para o lucro), liberal-capitalista (os danos ambientais devem ser incluídos no preço do produto, deixando-se ao mercado a tarefa de regular o equilíbrio ecológico), feminista (a exploração da natureza segue a atitude masculina de dominação), autogestora anarquista (a humanidade só poderá sobreviver se se organizar em pequenas comunidades autônomas que vivam em equilibrio com a natureza), e assim por diante. (ŽIŽEK, 1996, p. 17)

É nesse sentido que Viola e Leis (1992) organizam o conjunto de sistemas discursivos descontinuos (COUTINHO, 1994) como tendências mundiais do ecologismo, assumindo que a temática da sustentabilidade é multissetorial:

(...) o campo denotado pela expressão "ecologismo" é vasto e complexo, e compreende: (1) associações autodenominadas ambientalistas e o movimento ecologista stricto senso; (2) setores ecologistas da comunidade cientifica presentes hoje nas universidades e institutos de pesquisa; (3) individuos coletivos, formadores de opinião, que têm uma orientação ecologizante; (4) partidos verdes; (5) pequenos e médios empresários que incorporaram a dimensão ecológica na sua racionalidade microeconômica; (6) grupos e redes orientados para o desenvolvimento do potencial humano; (7) a comunidade dos técnicos das agências estatais voltadas para o meio ambiente; (8) movimentos sociais que não se identificam como movimentos ecológicos, mas que têm orientações valorativas e práticas ecologizadas; (9) setores minoritáriosecologizados de macroestruturas: agências estatais, corporações multinacionais, partidos politicos, associações profissionais (sindicatos e outros), associações empresariais e organizações religiosas; (10) camponeses cujo modo de produção leva em consideração a dimensão ecológica, seja por uma lógica histórico-tradicional, seja por um processo de aprendizado recente. (VIOLA e LEIS, 1992, p. 24)

Assim como Viola e Leis (1992), Castells (2002) propõe uma tipologia dos movimentos ambientalistas, organizando-as em função de seus objetivos e seus alvos, considerando que para cada "tipo" de atuação corresponde uma "identidade". As "identidades" propostas por Castells (2002) referem-se à enunciados que participam do discurso ecológico como formações discursivas que se complementam ou que se opõe, como vetores de força característicos do próprio discurso que engendram. 


\begin{tabular}{|l|l|l|l|}
\hline \multicolumn{1}{|c|}{ Tipologia dos movimentos ambientalistas } \\
\hline $\begin{array}{l}\text { Preservação da natureza } \\
\text { (Grupo dos Dez, EUA) }\end{array}$ & \multicolumn{1}{|c|}{ Identidade } & \multicolumn{1}{c|}{ Adversário } & \multicolumn{1}{c|}{ Objetivo } \\
\hline $\begin{array}{l}\text { Defesa do próprio espaço } \\
\text { (não no meu quintal') }\end{array}$ & Comunidade local & Agentes poluidores & $\begin{array}{l}\text { Qualidade de } \\
\text { vida/saúde }\end{array}$ \\
\hline $\begin{array}{l}\text { Contracultura, ecologia } \\
\text { profunda (Earth first!' } \\
\text { ecofeminismo) }\end{array}$ & O ser "verde" & $\begin{array}{l}\text { Desenvolvimento não- } \\
\text { controlado }\end{array}$ & $\begin{array}{l}\text { tecnocracia e } \\
\text { patriarcalismo }\end{array}$ \\
\hline $\begin{array}{l}\text { Save the planet } \\
\text { (Greenpeace) }\end{array}$ & $\begin{array}{l}\text { Internacionalistas na } \\
\text { luta pela causa } \\
\text { ecológica }\end{array}$ & $\begin{array}{l}\text { Desenvolvimento } \\
\text { global desenfreado }\end{array}$ & Sustentabilidade \\
\hline $\begin{array}{l}\text { Cidadãos preocupados } \\
\text { com a proteção do meio } \\
\text { Grünen) }\end{array}$ & $\begin{array}{l}\text { Estabelecimento } \\
\text { político }\end{array}$ & Oposição ao poder \\
\hline
\end{tabular}

DIEGUES (2004), por sua vez, define "escolas" do pensamento ecológico, derivadas de dois movimentos antagônicos que fundam o "ambientalismo" a partir da criação de áreas naturais protegidas nos Estados Unidos, resultado de importação de um modelo europeu de demarcação de áreas verdes para lazer público: o conservacionismo versus o preservacionismo dos recursos naturais. A idéia desses conceitos, utilizados até hoje, é distinguir ${ }^{55}$ a maneira como os recursos naturais são dispostos. A criação de áreas protegidas por lei, nos Estados Unidos, tais como Yellowstone (1872), Adirondacks (1885) e Yosemite (1890) (NASH, 1989) fundamenta a essa diferença. Esses espaços naturais, tornados de uso público, foram "conservados" dos processos de ocupação humana, voltados para a indústria e comércio. $\mathrm{O}$ intuito era o de atender às demandas de lazer da população e de conservação de fontes de água, marcas do viés utilitarista que dominava a noção de proteção da natureza e que persiste desde então. De maneira mais radical, eram também sugerida a criação de espaços naturais cuja delimitação definiria áreas isoladas do acesso público, para garantir a "preservação" (a não utilização nem mesmo como “paisagem" a ser "experimentada") da diversidade de espécies animais e vegetais e de formações minerais únicas, cujo "uso" poderia determinar o desaparecimento de tais especificidades do ambiente natural. Nesses locais, nenhuma atividade de lazer é permitida, de maneira a evitar

\footnotetext{
${ }^{55}$ Alguns especialistas, porém, defendem que essa distinção caiu em desuso, já que o isolamento idealizado das áreas de preservação é totalmente imaginário, e a fiscalização para mantê-las isoladas, comprovadamente ineficaz.
} 
qualquer tipo de distúrbio ao meio natural. Essas "unidades delimitadas" são denominadas “áreas de preservação permanente”, ao invés de "áreas de conservação”, porque, nestas últimas, o uso para lazer é permitido. Essa distinção sobre as estratégias de manutenção da "saúde" do ambiente natural e do acesso aos seus recursos, nasce, segundo DIEGUES (2004), da oposição de "escolas" assim denominadas: a Ecologia Profunda (Deep Ecology), a Ecologia Social, o EcoSocialismo/Marxismo e o Neo-Naturalismo Neo-Marxista de Sergei Moscovici ${ }^{56}$.

Todas essas formações discursivas, e as diferentes formas de traduzi-las, estão sintetizadas no vocábulo ecologia que mobiliza o discurso ecológico contemporâneo, definindo a necessidade, para determinados setores da sociedade, de 'esclarecer a opinião pública' sobre os efeitos danosos do desenvolvimento, enquanto, para outros, há necessidade de 'esclarecer a opinião pública' sobre os esforços das grandes empresas e do governo para evitar tais efeitos danosos. Esse embate de interesses é tanto emblemático quanto contraditório, constituindo mesmo a realidade discursiva em que estamos imersos:

\begin{abstract}
Assim, para onde quer que nos voltemos, reencontramos esse mesmo paradoxo lancinante: de um lado, o desenvolvimento contínuo de novo meios técnico-cientificos potencialmente capazes de resolver as problemáticas ecológicas dominantes e determinar o reequilibrio das atividades socialmente úteis sobre a superficie do planeta e, de outro lado, a incapacidade das forças sociais organizadas e das formações subjetivas constituídas de se apropriar desses meios para torná-los operativos. (GUATTARI, 1990, pg. 12).
\end{abstract}

Sob esse ponto de vista, pode ser relevante avaliar, porque, há cerca de 30 anos, no contexto do Brasil que vivia o auge do periodo da política de substituição de importações realizada pelo II PND (LAYRARGUES, 1998), a imagem de uma árvore tombando na Floresta Amazônica estava relacionada às idéias de desenvolvimento, progresso, riqueza. A mesma imagem, hoje, é interpretada de maneira completamente diferente e traz consigo uma significação bastante negativada, ou, pelo menos, não reflete uma interpretação tão unânime como a daquela época.

Com o auxilio da mídia, os diversos "tipos" de discurso sobre a sustentabilidade acabam sendo transformados em narrativas cujo embate reflete disputas de poder por diferentes grupos de subjetividades que promovem agenciamentos sociais e politicos visando a manutenção do sistema produtivo hegemônico.

\footnotetext{
${ }^{56}$ Moscovici, Sergei. Hommes domestiques et hommes sauvages. Paris: Union Générale d'Éditions, 1974.
} 
Guattari (1990) quando se refere às crises contemporâneas, nas quais inclui a questão ambiental, afirma serem elas resultado de um comprometimento "da relação da subjetividade com sua exterioridade - seja ela social, animal, vegetal, cósmica - numa espécie de movimento geral de implosão e infantilização regressiva". O autor lembra não apenas a existência de uma ordem que organiza o nivel da linguagem na espécie humana, mas especialmente a ordem que também estabelece relações e causa efeitos vivenciados social e culturalmente:

As formações políticas e as instâncias executivas parecem totalmente incapazes
de apreender essa problemática no conjunto de suas implicações. Apesar de
estarem começando a tomar uma consciência parcial dos perigos mais
evidentes que ameaçam o meio ambiente natural de nossas sociedades, elas
geralmente se contentam em abordar o campo dos danos industriais e, ainda
assim, unicamente numa perspectiva tecnocrática, ao passo que só uma
articulação ético-politica - a que chamo ecosofia - entre os três registros
ecológicos (o do meio ambiente, o das relações sociais e o da subjetividade
humana) é que poderia esclarecer convenientemente tais questões.
(GUATTARI, 1990, p. 8)

Ainda assim, surge uma nova prática social e cultural, que começa a buscar uma alternativa ao modelo econômico vigente, e que passa a ser marcada pela necessidade de se estabelecer regras e acordos para a implementação de critérios e limites que redesenhem o novo "desequilibrio de forças" representadas na relação Homem-Natureza. Essas medidas visam permitir o desenvolvimento e a manutenção dessa relação "de troca”, dentro do contexto sócio-econômico em que é mantida, tendo como objetivo alcançar qualidade de vida para os que aqui estão e para as gerações futuras.

Assim ampliada, a noção de sustentabilidade não mais se organiza apenas pela escritura cientifica que conceituou os termos ecossistema ou ecologia, nem pela escritura do transcendentalismo americano, que defendeu o direito de todos os seres vivos à vida, mas se redesenha como expressão de um fundamento biopolitico nos moldes foucaultianos:

Nos mecanismos implantados pela biopolitica, vai se tratar, sobretudo, é claro, de previsões, de estimativas, estatísticas, de medições globais; (...) trata-se, sobretudo, de estabelecer mecanismos reguladores que, nessa população global, com seu campo aleatório, vão poder fixar um equilibrio, manter uma média, estabelecer uma espécie de homeostase, assegurar compensações; em suma, de instalar mecanismos de previdência em torno desse aleatório que é inerente a uma população de seres vivos, de otimizar, se vocês preferirem, um estado de vida: mecanismos, como vocês vêem, como os mecanismos disciplinares, destinados, em suma, a maximizar forças e extraí-las, mas que passam por caminhos inteiramente diferentes. (...) Trata-se de agir de tal 
maneira que se obtenham estados globais de equilibrio, de regularidade; em resumo, de levar em conta a vida, os processos biológicos do homemespécie e de assegurar sobre eles não uma disciplina, mas uma regulamentação. (FOUCAULT, 2002, p. 293-294)

Assim, a organização do Clube de Roma (1968), da Conferência das Nações Unidas sobre Desenvolvimento e Meio Ambiente em Estocolmo (1972) e do Relatório "Nosso Futuro Comum"/Comissão Bruntland (1987) passam a ser entendidas como formas de se disciplinar a relação Homem-Natureza no sentido da biopolitica foucaultiana. São processos políticos que se impõem pela escritura, tornando legítimo a implementação e o desenvolvimento de interdições no campo jurídico, no campo da atuação política e da vida cotidiana contemporânea, além de agenciar discursos burocráticos em torno de negociações textuais que operam o que é politicamente e economicamente viável, aceitável, executável. Em espaços considerados públicos e transnacionais, o discurso ecológico contemporâneo, transformado em prática discursiva burocrática, gira em torno de si mesmo, preso a esse novo tipo de escritura biopolitica.

O discurso ecológico contemporâneo parece, então, organizar-se como nova metanarrativa, de tal maneira que durante muito tempo o pensamento ecológico foi entendido como uma reorganização dos movimentos sócio-politicos de esquerda ${ }^{57}$, após a queda do muro de Berlim em 1989. Parece fazer todo sentido ver otimismo em relação à Ciência, como saber-poder capaz de solucionar tecnologicamente todos os problemas da humanidade e a crença na legitimação e no potencial de acordo dos espaços transnacionais de discussão pública das negociações da "Rio-92" como substituição ou metáfora das metanarrativas propostas pelo ideário de Hegel (1770-1831), Marx (1818-1883) e Engels (1820-1895) esboçados, na prática sócio-política, pelo comunismo e pelo socialismo, do que aceitar "o fim da história" proposto por Fukuyama ${ }^{58}$.

Os veículos de informação, - por serem considerados meios aos quais se atribui a missão de "traduzir em troco miúdo" a complexidade dos eventos que sucedem em nosso dia-a-dia, com o intuito de promover o livre acesso à informação e a crítica aos diversos fenômenos sociais de

\footnotetext{
${ }^{57} \mathrm{O}$ cartunista Laerte ilustrou essa idéia, de maneira divertida, no Caderno "Folha Ilustrada" da Folha de São Paulo, em 1991, utilizando a dupla Gato \& Gata, da série "Piratas do Tietê":
}

Gato (caminha agitado, leva mãos à cabeça): "O comunismo acabou... e daí? Aonde foi parar a luta contra a miséria? Aonde foi parar a luta contra a opressão? A luta por liberdade?"

Gata (calmamente, em frente ao computador): "Foi tudo reprogramado prá 'ecologia'."

${ }^{58}$ FUKUYAMA, Francis. O fim da história e o último homem. Rio de Janeiro: Rocco, 1992. 
que se dizem testemunha - , operam simplificações de discursos cientificos e politicos, e acabam por inventar (a substituição de ecossistema por ecologia é apenas um deles), ou mesmo, forjar relações as mais diversas (de causa-efeito, inclusive) entre formações discursivas relativas à temática "ambiental", pois estabelecem significações distintas da maneira como os conceitos, cientificamente construidos e politicamente engajados, foram originalmente propostos.

Por ser o espaço que legitima a notícia e seu valor de verdade, a mídia entrelaça formações discursivas diversas que constituem o tecido social a partir do qual se pode falar sobre a questão ambiental e se pode instituir direitos e deveres em relação ao ambiente natural. A mídia veicula uma maneira de pensar a Natureza, entendida como ambiente natural, mas também os demais espaços "naturais" onde vive o Homem moderno. Ao legitimar a "nova" idéia de sustentabilidade, a mídia faz circular uma "releitura" do fundamento ecológico da unidade, que, agora, acopla ao conceito de ecossistema, outras noções como as de agroecossistemas (o ambiente "natural" dominado pelo Homem do campo) e dos ecossistemas urbanos (a cidade).

Essa "fragmentação" discursiva, como apontam Žižek (1996), Viola e Leis (1991), Castells (2002), Coutinho (2002), e Diegues (2004), estabelece novos "aparelhos" ou "sistemas" de produção de formações discursivas sobre o discurso ecológico “original”, reunidas, então, como temática da sustentabilidade. O aparelho midiático interfere na estruturação e organização das formações discursivas, na medida em que legitima os diferentes grupos de subjetividades que as enunciam: entidades ambientalistas, setores legislativos e juridicos do governo, agências ambientais, entidades do setor privado, cientistas e tecnólogos. Esses grupos produtores de subjetividades mobilizam o discurso da sustentabilidade, a nova imagem de mundo possivel, [re]organizando-o e o [re]significando, em vista de processos de subjetivação econômicos e políticos, estabelecendo oposições que "ao contrário de um eterno debate filosófico, expressam a constituição de sistemas discursivos descontínuos e muito diferentes, sob contextos sociais especificos." (COUTINHO, 2002).

Assim fragmentada em seu regime, ao mesmo tempo de operador e operado, a temática da sustentabilidade orquestra e expressa uma "gama heterogênea de estilos de vida e jogos de 
linguagem", como diz Eagleton ${ }^{59}$ (1987, apud HARVEY, 1992, p. 20) ao referir-se ao pósmodernismo. Orientada por, mas também orientando sistemas burocráticos, científicos e politicos, a temática da sustentabilidade é mantida por um conjunto complexo de elementos significantes que giram na indústria cultural e reafirmam a metafísica da presença que constitui a temática.

Simultaneamente, os sistemas de formações discursivas sobre a temática da sustentabilidade disputam a "centralidade simbólica" do discurso ecológico, que, ao contrário do amplo movimento cultural que o originou, ainda não "renunciou ao impulso nostálgico de totalizar e legitimar a si mesmo" (LAYRARGUES, 2000).

A meta desta seção não foi percorrer e desdobrar extensivamente esses vestígios, muito menos de empreender uma desconstrução dos textos fundantes do saber ecológico, mas explorar algumas de as conseqüências desses textos na construção de uma formação discursiva, visto que a História da Ciência pouca vezes é alvo de um estudo "do tipo" arqueológico ou genealógico como sugere Foucault:

(...) a história de um conceito não é, de forma alguma, a de seu refinamento progressivo, de sua racionalidade continuamente crescente, de seu gradiente de abstração, mas a de seus campos de constituição e de validade, a de suas regras sucessivas de uso, a dos meios teóricos múltiplos em que foi realizada e concluída sua elaboração. (...) prescrevem desta forma, para a análise histórica, não mais a pesquisa dos começos silenciosos, não mais a regressão sem fim em direção aos primeiros precursores, mas a identificação de um novo tipo de racionalidade e de seus efeitos múltiplos. (FOUCAULT, 2000, p. 4 - 5)

Ao defender a idéia de que, para tratar dos discursos dos homens com cuidado de método é preciso aceitar tratar apenas “de uma população de acontecimentos dispersos”, Foucault (2005) entende o discurso como um conjunto de enunciados que são irrupções de acontecimentos não necessariamente semelhantes ou facilmente interligados. É preciso desalojar as formas prontas e imediatas da continuidade, da sucessão e da identidade dos enunciados.

O discurso tem sua unidade no conjunto "constituido por todos os enunciados efetivos (quer tenham sido falados ou escritos), em sua dispersão de acontecimentos e na instância própria de

\footnotetext{
${ }^{59}$ EAGLETON, Terry. As ilusões do pós-modernismo. Rio de Janeiro: Jorge Zahar, 1998. apud HARVEY, 1992.
} 
cada um." (FOUCAULT, 2000, p. 29-30). Seu projeto é o de uma “descrição dos acontecimentos discursivos como horizonte para a busca das unidades que ai se formam" o que se distingue facilmente da análise da língua. Esse projeto entende a análise do campo discursivo como a compreensão do enunciado "na estreiteza e singularidade de sua situação; de determinar as condições de sua existência, de fixar seus limites da forma mais justa, de estabelecer suas correlações com os outros enunciados a que pode estar ligado, de mostrar que outras formas de enunciação exclui.” (idem, p. 31)

Dessa forma, Foucault destaca a importância do enunciado como irrupção histórica, restituindo a ele sua singularidade como acontecimento e mostrando que a descontinuidade "não é somente um desses grandes acidentes que produzem falha na geologia da história, mas já no simples fato do enunciado", pois,

Por mais banal que seja, por menos importante que o imaginemos em suas conseqüências, por mais facilmente esquecido que possa ser após sua aparição, por menos entendido ou mal decifrado que o suponhamos, um enunciado é sempre um acontecimento que nem língua nem sentido podem esgotar inteiramente. (FOUCAULT, 2000, p. 31)

Chamaremos de discurso ecológico ao conjunto de acontecimentos que demarcam o aparecimento de um estatuto, isto é, que impõem uma regra ou um regulamento para fixar e constitui a idéia do ecológico enquanto tal. Este estatuto, o estatuto ecológico, permeia todos os enunciados independentemente do momento de sua irrupção histórica.

O estatuto ecológico é o reconhecer nos seres vivos, e, portanto, em seus corpos, uma característica comum, isto é, uma base química e orgânica cuja manutenção é fundada na codependência e na inter-relação factual dos ciclos de matéria e energia que mantêm a vida biológica. Esse regulamento remonta o pensamento grego, mas se organiza como enunciado técnico-científico a partir do conceito de Ecossistema, estabelecido no início do século 20, que virá a conceber a complexa temática da Sustentabilidade na segunda metade do mesmo século.

Nessa mesma direção, ainda que desconfiando da carga de sentido estruturalista trazida na palavra, Derrida (2002, p. 229) retoma a possibilidade do acontecimento na história de um conceito como "a forma exterior de uma ruptura e de um redobramento". 
No que tange ao pensamento ecológico essa ruptura, esse redobramento que pela escritura funda sua premissa-chave se deu em três momentos de temporalidades muito distintas e conexões elipticas, referindo-se ao aparecimento do conceito de Ecossistema.

É com base nesse fundamento de unidade, em que unidade corresponde, ao mesmo tempo, às partes correspondentes do todo (os organismos vivos, os componentes minerais do planeta, as reações químicas que permitem a transferência de matéria e energia entre ambiente e seres vivos), como ao conjunto resultante da reunião das partes (ecossistema), cujo valor é maior do que as partes, permite que a palavra ecologia vire sinonimia de ecossistema, e "migre" para significar campos de saber tão diversos como os que, hoje, chamamos de Ecologia Política, Justiça Ambiental, Biologia da Conservação, Direito Ambiental, Ambientalismo ${ }^{60}$, Desenvolvimento Sustentável.

Estabelecer, pois, uma história das ciências que tratam das relações entre seres vivos e seu meio ambiente, - que é, convencionalmente, como se define o "objeto" da Ecologia -, implica a busca pelos vestígios dos saberes que se configuraram, nesse percurso, como saberes de uma História dos Sistemas do Pensamento Ecológico, por meio da escritura que legitima esses discursos. Destaca-se, assim, o logocentrismo característico desses dois aspectos ontológicos do pensamento ecológico - sua competência como Ciência positiva e seu historicismo, decorrente de fatores sociais, econômicos e culturais especificos cuja confluência favoreceu seu surgimento.

Os saberes (FOUCAULT, 2000) que definem a Ecologia como Ciência (relações entre seres vivos e seu meio ambiente) e como Politica Pública (a criação de leis, tratados e acordos e a reivindicação da ratificação internacional de alguns deles, sob a alegação da necessidade de se "garantir um futuro ecologicamente saudável para as gerações futuras") organizam-se, então, pela escritura e pelos textos que encadeiam e sustentam discursos. Ao mesmo tempo em que a escritura fixa acontecimentos, fatos e conceitos, os textos e discursos constituidos podem ser

\footnotetext{
60 Existe uma preocupação na produção acadêmica brasileira em precisar as significações para os termos 'ambientalismo' e 'ecologismo'. Percebe-se uma tendência do uso de 'ecologismo' como sinônimo de 'ecologismo profundo', que defende a ruptura com os modos de produção e consumo do capitalismo avançado, sendo considerado subversivo e radical, em oposição ao uso de 'ambientalismo', referido como o discurso ecológico empresarial ou governamental, ou seja, o discurso ecológico apropriado pelas instituições do sistema econômico hegemônico. Estas diferenças de significação aparecem em LAYRARGUES, 2000; VIOLA e LEIS, 1991; e LEIS, 1991.
} 
analisados, desconstruidos, revisitados, interpretados e reinterpretados, permitindo que aquilo que estava fixado possa mover-se no tempo devido à própria prática discursiva e à escritura de novos textos.

Nesse sentido, desde o pensamento grego até a atualidade, há caminhos históricos, descontínuos e complexos, que tecem o percurso de institucionalização de sistemas de pensamento pela escritura, culminando com a acepção moderna do Natural entendido como sinônimo de Ecossistema, um dos termos-chave para pensar o discurso ecológico contemporâneo e as representações que dele se fazem nos veículos de informação.

O pensamento ecológico resulta, então, de um arranjo, na História, de uma ciência e de um saber especificos, que foram fundamentados como verdades. Essas verdades tornam legítimo, na atualidade, a criação de leis, tratados e acordos, e a reivindicação da ratificação internacional de alguns deles, sob a alegação da necessidade de se "garantir um futuro ecologicamente saudável para as gerações futuras”.

A preocupação com o ambiente é entendida, assim, como a necessidade de manutenção de um tipo de saúde, - a "saúde ambiental" -, e de um tipo de equilibrio, ajustamento, adaptação, - o "equilibrio ecológico" -, dos quais a existência da espécie humana é dependente, a ponto de justificar a implementação de interdições no campo jurídico, no campo da atuação política e da vida cotidiana contemporânea, e, conseqüentemente, sua exploração textual e imagética pelos veículos de informação.

Do ponto de vista dos objetivos desta pesquisa, o Protocolo de Kyoto representa a escritura da ciência ecológica e o texto jurídico que define metas na ordem politica e econômica mundial, trazendo em si o fundamento da sustentabilidade como unidade planetária. Os acordos internacionais são, dessa forma, regimes disciplinares porque legislam e impõe uma visão planetária como meta comunitária, obrigatória e institucionalizada pela ONU, na figura do PNUMA, já que sob a alegação de que há o risco de barbárie, ou seja, de catástrofes ambientais capazes de desestabilizar o sistema econômico e financeiro hegemônico, a noção da sustentabilidade impõe-se como solução lógica e "óbvia”. 
O Protocolo de Kyoto não é, portanto, um texto encerrado em si mesmo, mas uma, entre muitas expressões escriturais possiveis de uma formação discursiva mais ampla. Ele é um "nó em uma rede" que "está preso em um sistema de remissões a outros livros, outros textos, outras frases". E isso constitui "um jogo de remissões" que "não é homólogo, conforme se refira a um tratado de matemática, a um comentário de textos, a uma narração histórica, a um episódio em um ciclo romanesco; em qualquer um dos casos, a unidade do livro [do texto do Protocolo], mesmo entendida como feixe de relações, não pode ser considerada como idêntica. (...) só se constrói a partir de um campo complexo de discursos. (FOUCAULT, 2005, p. 26). É o fundamento da unidade, encerrado na significação atualizada da palavra ecologia, que justifica e condiciona as operações do discurso ecológico constituindo-o como um dos principais enunciados-acontecimentos do século XX. 


\section{:: Referências bibliográficas ::}

ACOT, Pascal. História da ecologia. Rio de Janeiro: Editora Campus, 1990.

BORHEIM, Gerd. Filosofia do Romantismo. In: GUINSBERG, J. O Romantismo. São Paulo: Perspectiva, 2002. p. 75-111.

CASTELLS, Manuel. O poder da identidade. Rio de Janeiro: Editora Paz e Terra, 2002.

COUTINHO, Marilia. Reflexões acerca da estrutura do conhecimento ecológico: representações da natureza e representações de sociedade. Departamento de Sociologia, FFLCH/USP, São Paulo, 1994. Tese de Doutorado.

DeGROOD, David H. Haeckel's theory of the unity of Nature: a monograph in the history of philosophy. Amsterdam: B. R. Grüner Publishing Co., 1982.

DELEUZE, Gilles e GUATTARI, Félix. O anti-édipo. Capitalismo e esquizofrenia. Lisboa: Assirio \& Alvim, 1996.

DERRIDA, Jacques. Gramatologia. São Paulo: Perspectiva, 2006.

A escritura e a diferença. São Paulo: Perspectiva, 2005.

DIEGUES, Antonio Carlos. O mito moderno da natureza intocada. São Paulo: Hucitec/NUPAUB/CEC, 2004.

DORST, Jean. Antes que a natureza morra: por uma ecologia politica. São Paulo: Edgard Blücher, 1973.

FALBEL, Nachman. Os fundamentos históricos do romantismo. In: GUINSBERG, J. O Romantismo. São Paulo: Perspectiva, 2002. p. 23-50.

FLUSSER, Vilém. Los gestos: fenomenología y comunicación. Barcelona: Herder, 1994.

FOUCAULT, Michel. A ordem do discurso. São Paulo: Loyola, 1996.

. A arqueologia do saber. Rio de Janeiro: Forense Universitária, 2000.

. Aula de 17 de março de 1976. In: Em defesa da sociedade. São Paulo:

Martins Fontes, 2002.

GASMAN, Daniel. The Scientific Origins of National Socialism. Social Darwinism in Ernst Haeckel and the German Monist League. London: Macdonald \& Co., 1971. 
GOLLEY, Frank B. A History of Ecosystem Concept in Ecology: more than the sum of the parts. New York: Yale University Press, 1993.

GOMBRICH, Ernst H., Estranhos começos. Povos pré-históricos e primitivos. In: A

História da Arte. Rio de Janeiro: LCT, 1999. p. 39-53.

GOULD, Stephen Jay. Ontogeny and Phylogeny. Cambridge: Harvard University Press, 1977.

GUATTARI, Félix. Ecologia e movimento operário. In: Movimento sindical e defesa do meio ambiente - o debate internacional. Rio de Janeiro: IBASE, 2000. p. 13-22. Série Sindicalismo e Justiça Ambiental.

As três ecologias. Campinas: Papirus, 1990.

GUINSBURG, J. Romantismo, historicismo e história. In: O Romasntismo. São Paulo: Perspectiva, 2002. p. 13-21.

HARVEY, David. Condição pós-moderna: uma pesquisa sobre as origens da mudança cultural. Rio de Janeiro: Loyola, 1992.

HEIDEGGER, Martin. O tempo da imagem no mundo. In: Caminhos de Floresta. Lisboa: Fundação Calouste Gulbenkian, 1998. p. 95-138.

HEISER Jr., Charles B. Sementes para a civilização: a história da alimentação humana. São Paulo: Nacional, 1977.

JAMESON, Fredric. Modernidade singular. Rio de Janeiro: Civilização Brasileira, 2005.

LAYRARGUES, Philippe Pomier. A empresa 'verde' no Brasil: mudança ou apropriação ideológica? Ciência Hoje. Rio de Janeiro, v.27, n.158, p. 56-59, mar. 2000.

A cortina de fumaça. $O$ discurso empresarial verde e a ideologia da racionalidade econômica. São Paulo: Annablume, 1998.

LACAN, Jacques. A instância da letra no inconsciente ou a razão desde Freud. In:

Escritos. Rio de Janeiro: Jorge Zahar, 1998.

LEIS, Héctor Ricardo. Apresentação - O desafio ecológico à ordem mundial. In: (org.). Ecologia e política mundial. Rio de Janeiro: Vozes/FASE/AIRI-PUC-Rio, 1991. p.7-22.

LOPEZ, Luiz Manoel. Teoria do Sentido em Deleuze. An. Filos. São João del-Rei, São João delRei, n. 10. p. 203-220, jul. 2003. Disponivel em: http://www.fe.unicamp.br/dis/transversal/rizomas/luiz.pdf Acesso em: 03 Mai. 2008. 
LUHMAN, Niklas. Ecological communication. Chicago: The University of Chicago Press, 1989.

MAYR, Ernst. O desenvolvimento do pensamento biológico: diversidade, evolução e herança. Brasilia: UNB, 1998.

MORA, José Ferrater. Dicionário de Filosofia. São Paulo: Loyola, 2001.

MORIN, Edgar. Introdução ao pensamento complexo. Lisboa: Instituto Piaget, 2003.

NASH, Roderick Frasier. The rights of Nature: a history of environmental ethics. Madison: University of Wisconsin Press, 1989.

NUNES, Benedito. A visão romântica. In: GUINSBERG, J. O Romantismo. São Paulo: Perspectiva, 2002. p.51-74

SILVA, Telma Domingues. A biodiversidade e a floresta tropical no discurso de meio ambiente e desenvolvimento. Departamento de Lingüistica, IEL/Unicamp, Campinas, 1995. Dissertação de Mestrado.

TURNER, Frederick. O espírito ocidental contra a natureza. Mito, história e as terras selvagens. Rio de Janeiro: Editora Campus, 1990.

VIOLA, Eduardo J. e LEIS, Héctor R. Desordem global da biosfera e a nova ordem internacional: o papel organizador do ecologismo. In: LEIS, Héctor Ricardo. (org.). Ecologia e política mundial. Rio de Janeiro: Vozes/FASE/AIRI-PUC-Rio, 1991. p. 23-50.

WEBER, Max. A ética protestante e o espírito do capitalismo. São Paulo: Pioneira Thompson Learning, 2005.

ŽIŽEK, Slavoj. O espectro da ideologia. In: . Um mapa da ideologia. Rio de Janeiro: Contraponto, 1996. 


\section{Capítulo 2 :: A fotografia sobre meio ambiente ::}

$1::$ Imagem, texto e representação ::

2 :: Fotografia, paisagem e fotojornalismo::

3 :: Ato e gesto: camadas distintas da produção do fotográfico ::

:: Referências bibliográficas ::

\section{$1:$ : Imagem, texto e representação ::}

Imagem é palavra que surge na História como significação de encobrimento, de fuga da morte, de subterfúgio materialmente inventado para esconder o rosto do corpo morto.

A palavra imagem teve a sua origem no latim imago, que no mundo antigo significava a máscara de cera utilizada nos rituais de enterramento para reproduzir o rosto dos mortos. Ela nasceu, assim, da morte para prolongar a vida e apresentou, com isso, as noções de duplo e de memória. A imagem tinha o papel de recompor o homem, cujo corpo se decompõe pela morte. Desse modo, ela teve um caráter mágico ao proteger os vivos da visão do corpo em putrefação e de libertá-los de seus temores diante da morte. Logo, a imagem emergiu tendo a função de tornar presente o ausente e dar continuidade à existência terrena. (KERN, 2006; p. 15-16)

A idéia de temor da morte é uma noção advinda daquela hierarquização que impõe a separação entre corpo e alma, céu e terra, o animal e o humano, típica da mística originária dos povos do Oriente Médio durante o periodo antigo: a imposição de ordem a partir de um Deus que se opõe à Natureza. A vida, a prosperidade, a paz só são possiveis na segurança da cidade, na distância do deserto e do natural.

O ritual de passagem da morte é uma simulação de continuação da vida pelo uso da imagem. Na produção e reprodução das máscaras do periodo antigo está a reafirmação da ordem daquele misticismo dualista, que hierarquiza o mundo, produzido pela invenção de um Deus que protege o urbano-civilizado em detrimento do deserto, o lugar da perdição e da maldade.

Por outro lado, a imagem, como máscara para o ritual de encobrimento da morte, garante a permanência do mágico como algo que tem potencial de materialidade diferente da escritura, da lei expressa pela voz divina e que organiza vida e morte, real e sobrenatural. 
Imagem, máscara e mágica tornam-se, dessa forma, termos correlatos e metonímicos. A mágica dos rituais que se utilizam da máscara está presente na produção e uso de imagens que funcionam como elo entre os pares de opostos constituidos ora pelo dualismo do misticismo, que opera a escritura, ora pelo dualismo do racionalismo cientifico, que, por sua vez, fundamenta a construção dos aparelhos técnicos e tecnológicos produtores de imagens.

Em Redefinindo o conceito de imagem, Fabris (1998) aponta, com clareza, para a necessidade de compreensão dos complexos processos de produção de imagens por esses aparelhos (meios de comunicação) contemporâneos.

\begin{abstract}
A coexistência simultânea de imagens-objeto (fotogramas), de imagens-efeito (planos televisivos) e de imagens-projeto (computacionais ou virtuais) mostra a materialidade ${ }^{1}$ de cada tipo, inerente a determinados sistemas de pensamento e de produção, que devem ser investigados em suas estruturas fundamentais a fim de que a nova visualidade seja percebida como um momento, crucial sem dúvida, no qual podem vir a se encontrar presente e memória sem necessidade de exclusões mútuas. (FABRIS, 1998, p. 4)
\end{abstract}

Torna-se indispensável, para a autora, remeter-se a um conceito de imagem que permita trafegar por múltiplas áreas do conhecimento e que possa incluir o debate sobre a produção e a difusão técnica e tecnológica (eletrônica ou não) de imagens na atualidade.

Fabris (1998) critica a fragilidade do conceito de imagem como sinônimo de representação de algo externo, a "realidade". Ancorada na noção de representação como sinônimo de duplo, de cópia, de imitação, de reflexo do real, a noção de imagem e as teorias às quais ela dá corpo, não dão conta dos novos e intensos processos tecnológicos de produção imagética, nem caracterizam adequadamente as novas interações que esses processos possibilitam quando reproduzem, mimetizam ou transformam imagens técnicas produzidas artesanalmente, seja a fotografia produzida por câmeras mecânicas (com a revelação de películas, a ampliação em papel fotossensivel ou filmes e fotografias gerados digitalmente), ou as imagens produzidas pelo desenho, pela pintura, pela gravura, pela escultura.

\footnotetext{
1 "Les Techniques et l'Humanisme". In: V.A., L'Empire des Techniques, Paris, Seuil, 1994. p. 236 apud FABRIS,
} 1998. 
Essa preocupação de Fabris (1998) mostra como a idéia de representação no âmbito do estudo da imagem traz a tiracolo a noção de referente. Qual é o referente de uma imagem? Ele está na mente de quem fotografa ou nos olhos de quem vê a fotografia? Ele é resultado do processo de produção de imagens (ao que a autora denomina imagerie) e depende do suporte da imagem ou é inerente à interpretação da cena produzida pelo clique inicial?

Os aparelhos técnicos geradores de imagens mecânicas - quer analógicas, quer digitais - são, afinal, operados por dedos e por olhos, os mesmos que “desenham”, “pintam”, “escrevem” ou "imprimem" códigos em botões e teclados, - do computador de mesa, do laptop, do telefone celular, do smartphone, do $\mathrm{PDA}^{2}$-, configurando textos coloridos que brilham ou interferindo em fotografias, desenhos, animações ou simples traçados que, feito uma urdidura, constituem uma trama de informações para aqueles que abrem a tela, folheiam o livro, observam a primeira página do jornal exposta em frente à banca.

Há, assim, uma ruptura importante no que tange à forma como as imagens passaram a ser produzidas e reproduzidas e que provoca um redimensionamento na sua maneira de operar significações e potencializar sentidos: a noção de imagem técnica mecânica ${ }^{3}$.

O processo de produção de imagens técnicas mecânicas leva a inúmeros questionamentos: o processo de produção de uma imagem termina quando o autor/fotógrafo a considera finalizada ou ainda adentra o período de recepção da mesma? Os processos de interpretação, subjetivos e intersubjetivos (às vezes considerados como "processos de decodificação"), da imagem mecânica fazem parte dela ou não? A atribuição de significação e/ou de sentido não é, também, parte do processo de produção da imagem? Existe um “começo” e um "fim” (entendido como término) do processo de produção de uma imagem? O término seria o momento em que a imagem passa

\footnotetext{
2 Sigla para "Personal Digital Assistant", os modernos computadores de bolso, também chamados "Palm Tops".

${ }^{3}$ Evitaremos utilizar o termo imagem técnica isoladamente por entendermos que ele está fortemente associado ao famoso ensaio de Benjamin (1996), o qual identifica imagem técnica à imagem gerada pela câmera fotográfica ou cinematográfica, desconsiderando outras formas de imagem que também são técnicas, como o desenho, a gravura, a pintura e a escultura. Estas expressões artísticas produzem imagens técnicas eminentemente manuais, pois utilizam instrumentos e procedimentos específicos, para os quais são necessários extensos períodos de aprendizado e prática. Na nossa abordagem, a imagem técnica difere da imagem técnica mecânica produzida por qualquer aparelho técnico/tecnológico que possua lentes ou não (câmera fotográfica, câmera de cinema, de celular, microscópio eletrônico, radiografia, ultra-sonografia etc.), e que possa ser exibida em papel, celulóide, negativo ou pixels. Além disso, a pesquisa tenta, também, sustentar a existência de vínculos ontológicos entre as chamadas artes técnicas manuais e a escritura.
} 
a constituir parte de um imaginário ou o influencia ou o altera? Quando é que, enfim, esse processo termina, se é que termina? Como conhecê-lo? Como identificá-lo?

Alguns desses aspectos da produção e da natureza da imagem mecânica são comentados por Deleuze, quando cita análise de Louis Audibert ${ }^{4}$ sobre o cinema mudo:

(...) em virtude de seu tema mais profundo, a imagem visual remete a uma natureza física inocente, a uma vida imediata que não precisa de linguagem, enquanto o intertítulo, ou o escrito, manifesta a lei, o proibido, a ordem transmitida que vem quebrar essa inocência. (...) No cinema mudo em geral, a imagem visual é naturalizada, na medida em que nos dá o ser natural do homem na História ou na sociedade, enquanto o outro elemento, o outro plano que se distingue tanto da História quanto da Natureza, entra num "discurso" necessariamente escrito, isto é, lido, e posto em estilo indireto. (DELEUZE, 2005, p. 267-268)

Para Deleuze, na análise do cinema mudo, o intertitulo é lido como narrativa muda, como texto: ele é voz no sentido escritural, não no de fala. No cinema falado, o sonoro é materialmente ouvido, o que conduz a "uma nova dimensão da imagem visual, um novo componente" (idem, p. 269; grifo do autor). Para ele, o som (da voz dos personagens, da música incidental, dos efeitos sonoros diversos) constitui a imagem, compondo-a como um complexo visual. Não há mais o texto do intertitulo orientando uma narrativa linear de acontecimentos ${ }^{5}$, mas uma composição complexa que engendra os sons e as falas. "É provável, portanto, que o cinema falado modifique a imagem visual: enquanto é ouvido, ele faz ver, nela, algo que não aparece livremente no cinema mudo" (ibidem, p. 269; grifo do autor).

Para Flusser (1994), contudo, há diferenças ontológicas e técnicas importantes entre a imagem visual, mecanicamente produzida, que se constitui como fotografia e a que se constitui como

\footnotetext{
${ }^{4}$ AUDIBERT, Louis. L'ombre du son. In: Cinématographe. N. 48, Jul., 1979. p. 5-6. apud DELEUZE, 2005, p.268.

${ }_{5}^{5}$ Acontecimento, aqui, como entende Benveniste, quando assinala que "Aquele que fala faz renascer pelo seu discurso o acontecimento e a sua experiência do acontecimento. Aquele que o ouve apreende primeiro o discurso e, através desse discurso, o acontecimento reproduzido. (...) A linguagem reproduz o mundo, mas submetendo-o à sua própria organização" (Benveniste, 1995, p.26).

${ }^{6}$ A questão do intertítulo levantada por Deleuze deixa a impressão de que filmes estrangeiros dublados teriam um efeito visual e uma apreensão sensorial completamente diferente de filmes estrangeiros legendados, uma vez que, de acordo com a diferença que Deleuze estabelece entre cinema mudo e cinema falado, o texto lido interfere na fruição da imagem cinematográfica.
} 
cinema, especialmente no que tange às relações que se estabelecem nas dimensões do espaçotempo dos dois tipos de produção imagética.

Da la impresión de que no hay deslizamiento graduado entre la toma de cerca y la toma panorámica, sino sólo una transición de una a otro entre los diferentes campos. Esto diferencia por completo el gesto fotográfico del cinematográfico; la cámara no "viaja". Ese gesto está compuesto por una serie de saltos sobre estorbos invisibles y por una serie de decisiones. La búsqueda del fotógrafo es una serie de procesos decisorios abruptos. El fotógrafo recorre el espacio-tiempo, que está formado por distintos campos de visión, por diferentes "cosmovisiones", y en consecuencia por estorbos que separan esos campos visuales. El carácter cuántico del gesto de fotografiar (el hecho de que en el mismo se trate de una clara et distincta perceptio) asemeja su estrutura a un gesto filosófico, mientras que el gesto de filmar diluye esa estrutura. La causa de la diferencia es evidentemente de naturaleza técnica: el fotógrafo mira - al igual que el filósofo - a través de un aparato "categorial" y con ello persigue la meta de captar el mundo como una serie de imagénes distintas (de conceptos definibles). El filmador mira a través de un aparato "procesual" con el ánimo de apresar el mundo como una corriente de imágenes indivisibles (de conceptos indefinibles también). (FLUSSER, 1994, p. 108-109; grifos nossos)

Imagens visuais fotográficas possuem, assim, dois aspectos centrais - o de representarem visões de mundo, tal qual define Heidegger ${ }^{7}$, e o de serem silenciosas.

O silêncio, na imagem fotográfica, é ausência da voz (a voz mitica, encoberta pela escritura, que aparecia no cinema mudo como intertitulo) e do som (o combinado complexo de sons do cinema "falado"). "Imagens são irremediavelmente mudas", diz Burke (2004, p. 43). Talvez, daí, nossa necessidade desesperada por inseri-las em contextos e "algemá-las" a textos. Burke se

\footnotetext{
7 "Só se chega à ciência como investigação se, e apenas se, a verdade se transformou em certeza do representar. É na metafísica de Descartes que o ente é, pela primeira vez, determinado como objetividade do representar. (...) Quando meditamos sobre a modernidade, perguntamos pela imagem do mundo moderna. Caracterizamo-la através de uma demarcação contra a imagem do mundo medieval e antiga. (...) $\mathrm{O}$ mundo está aqui como designação do ente na totalidade. $O$ nome não está limitado ao cosmos, à natureza. Ao mundo pertence também a história. Mas mesmo a natureza e a história, e ambas no seu entrelaçamento recíproco, sobrepondo-se uma à outra, não esgotam o mundo. Nesta designação está co-implicado o fundamento do mundo, independentemente de como é pensada a sua referência ao mundo. (...) "Temos a imagem de algo" não quer apenas dizer que o ente nos é em geral representado, mas que ele, em tudo aquilo que lhe pertence e que nele está reunido, está diante de nós como sistema. Em "ter a imagem" ressoa o estar-a-par, estar armado e preparado. (...) Imagem do mundo, compreendida essencialmente, não quer, por isso, dizer, imagem que se faz do mundo, mas o mundo concebido como imagem. (...) $\bigcirc$ que distingue a essência da modernidade não é que se transite de uma precedente imagem do mundo medieval para uma imagem do mundo moderna, mas sim que o mundo se torne, em geral, imagem." (HEIDEGGER, 1998, p. 110-113)
} 
pergunta, invertendo o sentido do provérbio $^{8}$ : "Pode o sentido [significação] de imagens ser traduzido em palavras?" (idem). A essa "transcrição", Burke chama de comunicação e defende que ela é alcançada pelos historiadores se souberem "ler" as imagens. Na defesa de uma posição contrária, Gombrich (1982) argumenta que

The assertion that statements cannot be translated into images often meets with incredulity, but the simplest demonstration of its truth is to challenge the doubters to illustrate the proposition they doubt. You cannot make a picture of the concept of statement any more than you can illustrate the impossibility of translation. It is not only the degree of abstraction of language that eludes the visual medium; the sequence from the primer 'The cat sits on the mat' is certainly not abstract, but although the primer may show a picture of a cat sitting on a mat, a moment's reflection will show that the picture is not the equivalent of the statement. We cannot express pictorially whether we mean 'the' cat (an individual) or 'a cat' (a member of a class); moreover, although the sentence may be one possible description of the picture, there are an infinite number of other true descriptive statements you could make such as 'There is a cat seen from behind', or for that matter 'There is no elephant on the mat'. When the primer continues with 'The cat sat on the mat', 'The cat will sit on the mat', 'The cat sits rarely on the mat', 'If the cat sits on the mat...' and so on ad infinitum, we see the word soaring away and leaving the picture behind. (GOMBRICH, 1982, p. 138-139; grifo nosso) ${ }^{9}$

${ }^{8}$ Ein Bild sagt mehr als 1000 Worte, diz o provérbio, em tantas línguas quantas forem possiveis, e cuja origem
ninguém sabe ao certo precisar. A versão em alemão é citada por Peter Burke (2004, p. 11) como sendo de Kurt
Tucholsky, jornalista da República de Weimar. A Wikipedia explica que a versão em inglês "A picture is worth a
thousand words" tem origem em um jornal de anúncios, voltado para o comércio, no qual o americano Fred R.
Barnard tenta estimular o uso de imagens na publicidade "outdoor" feita, na década de 20 , por veículos
automotores, nas principais cidades do leste americano. As frases originais são, porém, um pouco diferentes do
provérbio, como o conhecemos: "A look is worth a thousand words", é de 1921, e "One look is worth ten thousand
words", é de 1929. A primeira frase tem origem atribuída a um "filósofo japonês" e a segunda é definida como "um
conhecido provérbio chinês". Para ver os anúncios da década de 20 acesse:
http://www2.cs.uregina.ca/ hepting/research/web/words/history.html (Acesso em: 20 Jan. 2008). O artigo na
Wikipedia também mostra que outras frases semelhantes, anteriores à criação do referido "provérbio", já aludiam a
essa sensação de capacidade da imagem em resumir ou reunir todas as informações importantes numa única
superfície enquadrada, citando o escritor russo Ivan Turgenev, que em seu livro Fathers and Sons (1862) escreveu "A
picture shous me at a glance what it takes dozens of pages of a book to expound" e, mesmo, Napoleão Bonaparte que
disse: "Un bon croquis vaut mieux qu'un long discours" (em inglês, "A good sketch is better than a long speech.") Para mais
detalhes ver: http://en.wikipedia.org/wiki/A_picture_is_worth_a_thousand_words (Acesso em: 20 Jan. 2008).

9 "A afirmação de que declarações (ou enunciados) não podem ser traduzidas em imagens freqüentemente enfrenta incredulidade, mas a demonstração mais simples de sua verdade é desafiar os céticos a ilustrar a proposta da qual eles duvidam. Você não pode fazer um quadro (pintura, retrato) do conceito de declaração (ou enunciado) mais do que pode ilustrar a impossibilidade de tradução. Não é apenas o grau de abstração de linguagem que escapa (engana, trapaceia) ao meio visual; a seqüência a partir da frase iniciadora 'O gato senta-se no tapete' certamente não é abstrata, mas mesmo que a frase iniciadora possa mostrar um quadro (fotografia, desenho) de um gato sentado num tapete, um momento de reflexão mostrará que o quadro (fotografia, desenho) não é o equivalente da declaração (enunciado). Nós não podemos expressar pictoricamente se queremos dizer 'o gato' (um indivíduo) nem 'um gato' (um membro de uma classe); além do mais, embora a sentença possa ser uma possível descrição do quadro, há um número infinito de outras declarações descritivas verdadeiras que você pode fazer tal como 'há um gato visto de trás', ou no que diz respeito ao assunto, 'não há nenhum elefante no tapete'. Quando a seqüência 
A máscara, a pintura, o desenho, a gravura, a escultura desenvolveram-se como expressões artísticas ligadas à a oposição mística institucionalizada pelo dualismo que configura tantoo racionalismo cientifico como os rituais religiosos. Assim, são imagens manuais que estariam ligadas à escritura porque o gesto que as produz depende de um "objeto escritural": lápis, talhadeira, goiva, pincel. O gesto de desenhar (pintar, gravar, esculpir) adentra o universo da escritura ao tornar-se letra e alfabeto fonético, deflagrando a escrita e a História. Assim, os gestos produtores de imagens técnicas manuais retêm uma origem comum em termos de operação de pensamento e em termos de instrumento técnico utilizado. O ferramental artístico é estruturalmente escritural.

Em sua essência a obra de arte sempre foi reprodutivel. (...) A litografia estava em seus primórdios quando foi ultrapassada pela fotografia. Pela primeira vez no processo de reprodução da imagem, a mão foi liberada das responsabilidades artísticas mais importantes, que agora cabiam unicamente ao olho. Como o olho aprende mais depressa do que a mão desenha, o processo de reprodução das imagens experimentou tal aceleração que começou a situar-se no mesmo nível que a palavra oral. (BENJAMIN, 1996, p. 166-167)

É nesse sentido, inclusive que Benjamin (1996) coloca a controvérsia quanto ao valor artístico das produções da fotografia e da pintura. Tal embate esconde ou camufla uma questão de importância maior: a da refuncionalização da arte pela emancipação de seus fundamentos de culto devido à era da reprodutibilidade técnica. Para ele, "a invenção da fotografia alterou a própria natureza da arte" (BENJAMIN, 1996, p. 176).

Do ponto de vista ontológico, entretanto, o mesmo gesto de desenhar afasta-se da escritura ao tornar possivel a passagem da imagem manual à imagem mecânica. É a combinação complexa entre o gesto de desenhar (a inscrição ou a grafia), o gesto de pintar (a pintura) e o gesto de busca (o método científico) que permite o aparecimento do gesto de fotografar.

O gesto de fotografar diferencia-se do gesto de desenhar, de pintar, de esculpir, de escrever, de filmar porque ele opera sem a necessidade de instrumento escritural. Não há voz, nem som que o oriente ou determine diretamente, a não ser as formações discursivas que engendram o contexto, a

continua com 'O gato sentou-se no tapete', 'O gato sentar-se-á no tapete', 'O gato senta-se raramente no tapete', 'Se o gato sentar no tapete... ' e assim por diante ad infinitum, vemos a palavra ascendendo para longe, abandonando o quadro (fotografia, desenho)". Tradução livre. 
visão de mundo, o recorte da cena acerca da qual o fotógrafo decide seu clique. Essa característica da fotografia, de ser independente da escritura pode, talvez, explicar o duro período de debates e críticas que essa atividade sofreu até ser finalmente aceita como uma manifestação genuinamente artística. Ela rompia com uma expressão do gesto que a vinculava à escritura que modelava e informava a produção de duplos, cópias e reproduções vigente até seu aparecimento.

A necessidade existente de se impor às imagens fotográficas uma significação com base em referentes escriturais decorre dessa "liberdade de expressão" que cada fotografia/fotograma possui devido ao gesto fotográfico que o definiu. São os textos associados a cada fotografia/fotograma que impõem significação escritural à imagem fotográfica, uma vez que ela é desprovida da mesma em todo seu processo de produção. Assim, ainda que acompanhadas de legendas, textos, ou títulos, a relação que a imagem fotográfica possui com a escritura é de competição, atrito, desafio ou desentendimento. A ordem da voz e da lei quer forçar as imagens a parear com as descrições que delas tentam se apropriar e lhe impor significado, significação, sentido.

\section{2 :: Fotografia, paisagem e fotojornalismo ::}

Existem, claro, vários outros aspectos que caracterizam o hibridismo já bastante complexo da fotografia.

Virilio detecta três tipos de presenças nas experiências de Niepce: uma herança artística, patente no uso da câmara escura, no sentido dos valores e do negativo emprestados à gravura e na influência do processo litográfico; uma lógica industrial, derivada, sobretudo, deste; um vetor cientifico, presente no uso de lentes de telescópio ou microscópio. (FABRIS, 1990, p. 174) ${ }^{10}$

\footnotetext{
10 "Na realidade, o debate nascia antes de mais nada do fato de que, como a maior parte das invenções técnicas,a da fotografia é a execução de um híbrido. Graças à correspondência de Nicéfore Niepce, tornourse relativamente fácil decifrar o processo desta hibridação: além da importante herança artística (a utilização da câmara escura, o sentido dos valores e do negativo vindo da gravura...), a litografia, de invenção recente, impõe a Niepce a idéia de uma permeabilidade seletiva do suporte da imagem exposta a um fluido... sem esquecer o nivel industrial, com o potencial de reprodução mecânica da litogravura. Finalmente, o cientifico está igualmente presente, já que Niepce utiliza o instrumento de Galileu - lentes de lunetas astronômicas ou de microscópios." (VIRILIO, 2002, p.73)
} 
Desde a sua origem como nova técnica mecanizada, a fotografia deixou de ser uma arte mecânica, definição marcada pela produção imagética dos fotógrafos pictorialistas, que utilizavam referências da arte renascentista para conceber suas imagens, e passou, com o uso na guerra, pelo reconhecimento como um objeto de valor documental, evidenciado pelos trabalhos de Steichen, Strand e Capa.

Com o desenvolvimento tecnológico dos novos meios de comunicação, associa-se a essas características, a de um jogo ou brincadeira efetuado por brinquedo (FLUSSER, 1998) e que pode ser facilmente observado no uso das imagens digitais nos ambientes de Internet, por exemplo. Todos esses atributos da fotografia são explorados/legitimados/apropriados pelo discurso estético modernista que invade o fotojornalismo, como veremos a seguir.

Em seu ensaio sobre os espaços discursivos da fotografia, Krauss (1985) propõe que o desenvolvimento do discurso estético do século XIX estabeleceu a parede, quer seja do museu, da galeria ou da sala privada, como o espaço que legitima a obra de arte. A parede é o espaço de exibição capaz de excluir tudo aquilo que não receber status de Arte:

Given its function as the physical vehicle of exhibition, the gallery wall became the signifier of inclusion and thus, can be seen as constituting in itself a representation of what could be called exhibitionality, or that which was developing as the crucial medium of exchange between patrons and artists within the changing structure of art in the nineteenth century. (Krauss, 1985, p. 133; grifo da autora $)^{11}$

Essa noção, da função de exibição da parede e da necessidade da obra de arte se "adaptar" a ela, parece assemelhar-se a um mesmo processo de adaptação da fotografia jornalistica ao espaço de sua publicação, o jornal.

Isto implica em afirmar que, apesar dos esforços, por parte das redações e editorias, para definir os conceitos de notícia ${ }^{12}$ e de valor-notícia ${ }^{13}$, optamos, aqui, por partir da premissa de que um fato

\footnotetext{
11 "Dada sua função como veículo físico de exibição, a parede da galeria tornou-se o significante da inclusão e, assim, pode ser vista como constituindo em si uma representação do que pode ser chamada exibicionalidade, ou aquela que se desenvolvia como o meio crucial de câmbio entre patronos e artistas dentro da mudança de estrutura da arte no século dezenove". Tradução livre.

12 "O que se busca é a notícia: o fato comprovado, relevante e novo. Quanto mais um fato puder gerar conseqüências para o mundo, para a sociedade ou para a maioria dos leitores, mais relevante ele é. Quanto mais inesperado, mais noticioso; quanto maior a força de quem está interessada em ocultá-lo, também.” Manual de
} 
ou evento só se produz como notícia, - só passa a "existir" como notícia -, quando estampado nas "páginas" de algum veículo da mídia, quer seja em papel, pixels ou sinais eletromagnéticos ${ }^{14}$.

Isto significa concordar com a proposta de Krauss (1985), estabelecendo analogamente a "página da mídia" como espaço de exibição que legitima a fotografia jornalística, valorizando-a como tal e estabelecendo, ao mesmo tempo, o que é fotojornalismo e o que não é, pela exclusão de imagens no espaço em questão.

O fotojornalismo constitui-se, assim, por meio de uma lógica da estética modernista que, ao priorizar a forma do espaço de exibição como operação de legitimação da pintura, repete a mesma operação observada no espaço de exibição que legitima a notícia. A "página" do meio de comunicação não apenas legitima uma idéia de notícia ${ }^{15}$, mas concatena uma noção de verdade sobre os fatos relatados. O espaço da notícia legitima as imagens técnicas mecânicas nele incluidas para exibição. Fotojornalismo é a fotografia cujo valor de notícia está discursivamente legitimado ${ }^{16}$.

Redação e Estilo da Folha de São Paulo. Disponível em: http://www1.folha.uol.com.br/folha/circulo/manual producao introducao.htm Acesso em: 14 Mar. 2008.

13 "Valor-notícia é um valor subjetivo que determina a importância que um fato ou acontecimento tem para ser noticiado. Por este motivo é também designado de critério de noticiabilidade. Na prática, a decisão acerca do que é ou não notícia é tomada de maneira informal por editores que se baseiam na sua experiência profissional e intuição. Os fatores ou critérios que dão a um fato valor-notícia coincidem na maior parte das redações dos meios de comunicação social. Em 1965, Johan Galtung e Mari Holmboe Ruge enumeraram esses fatores. A sua análise mantém-se atual embora existam outras tipologias." (Wikipedia) Disponivel em: http://pt.wikipedia.org/wiki/Valor-not\%C3\%ADcia Acesso em: 14 Mar. 2008.

14 "News is any new information or information on current events which is presented by print, broadcast, Internet, or word of mouth to a third party or mass audience." (Wikipedia). Disponivel em: http://en.wikipedia.org/wiki/News Acesso em: 14 Mar. 2008. [A notícia é qualquer nova informação ou informação em acontecimentos atuais que é apresentada por impressão, transmissão, Internet, ou boca-a-boca a uma terceira parte ou à audiência de massa. Tradução Livre.]

${ }^{15}$ Digo aqui "idéia de notícia" uma vez que os faits divers (Barthes, 1970) têm ampliado sua presença nos meios noticiosos em geral e a "miscigenação" entre "hard news" e "soft news", para usar o jargão da área, permeiam todas as formas jornalísticas (tanto escritas quanto faladas) de maneira quase característica.

${ }^{16}$ Essa visão é corroborada pelos critérios para o Prêmio Pulitzer de fotografia, que é dividido em duas categorias: SPOT NEWS PHOTOGRAPHY (definição que foi alterada para BREAKING NEWS PHOTOGRAPHY, a partir de 2000) e FEATURE PHOTOGRAPHY. As famosas imagens de Edward T. Adams, "Saygon Execution, 1969", e Huỳnh Công Ut, "Napalm bombing, 1972" ganharam o Pulitzer na primeira categoria. Ambas as fotografias também ganharam o prêmio de Foto do Ano da World Press Photo Contest. Já a fotografia de Kevin Carter (a imagem de uma menina sudanesa que rastejava em direção à base de ajuda humanitária enquanto um abutre a observava, em 1993), foi contemplada na segunda categoria. "Feature" (no jargão jornalístico inglês) corresponde aos faits divers do jargão jornalístico francês, os chamados "fatos diversos", ou seja, os assuntos que não podem ser categorizados nas editorias tradicionais dos veículos. Observa-se que, como em vários outros "conceitos" cristalizados pelo jargão jornalístico, a idéia de que os "features" ou "faits divers" correspondem a fatos desconectados de historicidade jornalística (e que, por isso, referem-se ao seu próprio caráter interno, sendo de interesse apenas como fato inusitado ou pitoresco), ganha potencial para uma discussão mais ampla. Se nos 
Produzindo imagens em função desse contexto, o fotojornalista tenta acompanhar as "tendências" de "estilo" que farão com que suas imagens tenham mais "chance" de ser validadas como notícia (da mesma maneira que os artistas competem pelo espaço de exibição da parede do museu). Esses critérios de "estilo" refletem um modo de se fazer fotojornalismo, ou seja, um modo de "decupar", fragmentar ou recortar as cenas cotidianas, transformando-as em momentos congelados com potencial de valor-noticia. Os fotojornalistas defendem "pontos de vista" estéticos como um "estilo" de fotografia, na qual as composições das imagens produzidas precisam estar "isentas" de determinados elementos "subjetivos", da mesma maneira que a produção da notícia escrita.

Entretanto, assim como no texto, também na imagem dita "jornalistica" a neutralidade é uma característica muito difícil de se julgar, que dirá de se estabelecer, mesmo quando se considera a discussão sobre critérios "claros" e "objetivos" capazes de orientar a produção de imagens para que possam receber o rótulo de fotojornalismo. Ao fim e ao cabo, para que tenham valor de notícia e possam ser caracterizados como fotojornalismo, os elementos que compõem uma fotografia precisam ser legitimados pelo espaço de exibição por meio do qual ela receberá o status de noticia.

O fotojornalismo que nos interessa é aquele que se constituiu a partir da fotografia de paisagem. Esse tipo de fotografia entendida como uma construção artística que transfere a tridimensionalidade monumental do espaço natural para a bidimensionalidade do plano é também abordado por Krauss (1985). A autora explica de que maneira a paisagem transformouse na experiência comprimida do plano, outra marca do modernismo na pintura, a partir de1860:

detivéssemos mais demoradamente na análise comparativa das imagens fotográficas premiadas por essas duas categorias do Pulitzer e na comparação de imagens premiadas por diferentes prêmios internacionais voltados para o fotojornalismo, poderíamos perceber com mais atenção que os elementos que as compõem não parecem ser tão diferentes ou específicos como a temática que abordam - basicamente as "tragédias" da humanidade. A subjetividade ou, talvez, os agenciamentos de subjetividades que determinam as premiações não parecem estabelecer diferenças claras entre categorias de fotografias com propósitos jornalísticos supostamente tão distintos. O valor-notícia de uma imagem entendida como "braking news" / "spot news" é tão construído quanto o "valorpitoresco" de uma imagem categorizada como "feature photography”. São as formações discursivas em voga no momento da premiação que definem esses valores e não as tipologias teóricas do valor-notícia. É o espaço de "exibicionalidade" construído pelas "páginas" da mídia que determinam, corroboram ou alteram esses valores, associado, ainda, ao espaço de "exibicionalidade" dessas premiações que legitimam o "estilo fotojornalístico". 
It began with the insistent voiding of perspective, as landscape painting counteracted perspectival recession with a variety of devices, among them sharp value contrast, which had the effect of converting orthogonal penetration of depth - effected, for example, by a lane of trees - into diagonal ordering of the surface. (...) The synonymy of landscape and wall (the one a representation of the other) of Monet's late water lilies is thus an advanced moment in a series of operations in which aesthetic discourse resolves itself around a representation of the very space that grounds it institutionally. (...) This constitution of the work of art as a representation of its own space of exhibition is in fact what we know as the history of modernism. (KRAUSS, 1985, p. 133)

A fotografia, ao repetir essa possibilidade de "reconstrução" da paisagem no plano, transporta essa forma de visão para outros espaços, além da parede do museu. É o “aprendizado" do olhar e a adequação ao plano, ambos advindos da pintura moderna, que "permitem" a reprodução da tridimensionalidade (ou quadrimensionalidade, se incluirmos o tempo, entendido como a velocidade do obturador definida pelo fotógrafo no momento do gesto, como indica Flusser, 1994) “impressa” na superfície da fotografia.

O fotografar a paisagem nasce, ainda, da prática dos levantamentos geológicos norte-americanos do final do século XIX: os chamados The Great Surveys (U.S. Geological and Geographical Surveys of the American West) ${ }^{17}$. É no contexto desses grandes levantamentos geológicos que Krauss (1985) afirma que a fotografia sobre a paisagem pertence a um domínio especifico da cultura, assumindo expectativas também específicas em relação ao usuário da imagem e em relação ao tipo de conhecimento que destacadamente carrega e divulga, e que, para ela, continua sendo o discurso estético:

(...) if we ask what it is a representation of, the answer must be that within this space [the space of aesthetical discourse] it [photography] is constituted as a representation of the plane of exhibition, the surface of the museum, the

\footnotetext{
${ }^{17}$ Entre 1860 e 1879, quatro expedições importantes patrocinadas pelo governo dos Estados Unidos pesquisaram, traçaram, e exploraram uma grande região geográfica a oeste do Rio Mississipi. Os mapas e relatórios dessas expedições foram concluídos e consolidados sob os auspícios do, então, recém-criado escritório da Agência de Análises Geológicas dos EUA e são referidas a como as "Grandes Pesquisas do Oeste Americano". Nos doze anos em que Hayden coordenou as Análises Geográficas e Geológicas dos Territórios dos EUA, vários cientistas e artistas contribuíram com seus talentos ao propósito das pesquisas. Alguns deles foram William Henry Jackson, Thomas Moran, John Wesley Powell, George Montague Wheeler, Clarence King e Timothy O'Sullivan.

Disponivel em:

http://www.onlinenevada.org/u.s._geological_and_geographical_surveys_of the_american_west:_the_great_surv eys Acesso em: 13 Mar. 2008.
} 
capacity of the gallery to constitute the objects it selects for inclusion as Art. (KRAUSS, 1985, p. 134). ${ }^{18}$

Krauss (1985) inclui a fotografia de paisagem produzida pelos grandes levantamentos geológicos norte-americanos como expressão do discurso estético, mas lembra que,

As Alan Trachtenberg ${ }^{19}$ argues, the government-sponsored Western surveys were intended to gain access to the mineral resources needed for industrialization. It was an industrial as well as a scientific program that generated this photography, which "when viewed outside the context of the reports it accompanied seems to perpetuate the landscape tradition." Trachtenberg continues: "The photographs represent an essential aspect of the enterprise, a form of record keeping; they contributed to the federal government's policy of supplying fundamental needs of industrialization, needs for reliable data concerning raw materials, and promoted a public willingness to support government policy of conquest, settlement and exploitation." (KRAUSS, 1985, p. 132; grifos nossos) ${ }^{20}$

As considerações de Trachtenberg (1982), citadas por Krauss (1985), assinalam aspectos fundamentais do uso social, político e econômico da fotografia na segunda metade do século XIX e que participam do seu estabelecimento como fotografia sobre o meio ambiente. Para nós, interessam, principalmente as formações discursivas que engendram esses usos e não os usos em si mesmos.

O fato de Krauss (1985) assinalar que a fotografia de paisagem (landscape photography), é utilizada como registro do meio natural visto como ambiente a ser conquistado e dominado, reforça nossa abordagem no que tange à entrada da fotografia como técnica mecânica de representação no sentido heideggeriano do termo. O uso da fotografia como documento de pesquisa geológica no final do século XIX, muito antes do desenvolvimento e estabelecimento das

\footnotetext{
18 "Se pedimos o que é uma representação de, a resposta deve ser que dentro deste espaço lo espaço do discurso de estético] ela [fotografia] é constituída como uma representação do plano de exibição, a superfície do museu, a capacidade da galeria de constituir os objetos que seleciona para inclusão como Arte." Tradução livre.

${ }^{19}$ TRACHTENBERG, Alan. The Incorporation of America. New York: Hill and Wang, 1982, p.20 apud KRAUSS, 1985, p. 132.

20 "Como Alan Trachtenberg argumenta, as pesquisas do oeste americano patrocinadas pelo governo foram pensadas como maneira de se conseguir acesso aos recursos minerais necessários para a industrialização. Foi um programa industrial e científico que gerou esta fotografia, que "quando vista fora do contexto dos relatórios que as acompanhava parecia perpetuar a tradição da fotografia de paisagem". Trachtenberg continua: "As fotografias representam um aspecto essencial da empresa governamental e científica, uma forma de manter registro; as fotografias ajudaram as políticas públicas do governo de atender às demandas fundamentais da industrialização, como acesso a dados de confiança relativos às fontes de matérias-primas, e promoveram a vontade pública de apoiar essa política de conquista, de colonização, assentamento e exploração". Tradução livre.
} 
fotografias aéreas ${ }^{21}$ e das fotografias via satélite, significa a apropriação dessa mídia pela Ciência como empresa moderna e pelo Estado como definidor de politicas em relação ao uso dos recursos naturais. A fotografia representa no sentido de significar uma visão de mundo que combina o empreendimento científico e os discursos de poder acerca do controle dos, agora reconhecidos, bens naturais.

A fotografia de paisagem que surge a partir de 1860 engendra, assim, mundivisões e discursos ${ }^{22}$ outros, além do estético: a visão de mundo moderno que tem, na Ciência, a empresa da busca de soluções de problemas e, no Estado, o direito sobre a exploração de bens naturais, entendidos como conteúdo de seu território e não mais como paisagem para puro deleite de observação e descrição. Como escreve Trachtenberg (1982): "It was an industrial as well as a scientific program that generated this photography". O olhar do fotógrafo "a serviço" de um discurso que se organiza como escritura científica, política e jurídica e se impõe sobre a produção de imagens técnicas mecânicas sobre a Natureza ou o meio ambiente ${ }^{23}$.

Do deserto (espaço do pecado e da privação), à floresta (espaço de convívio, admiração e inspiração para o gesto de busca), a bem natural (espaço a ser não apenas dominado, mas que se constitui como objeto de consumo do Homem, mais que foco de inspiração para o gesto de busca):

\footnotetext{
${ }^{21}$ A primeira fotografia aérea foi feita por Nadar, em 1858, a bordo de um balão que sobrevoou Paris. O uso da fotografia aérea só irá ser mais intenso a partir da Primeira Guerra Mundial e voltado para fins militares.

22 "If a worldview is a discursive construct, then it follows that there are as many worldviews possible as there are discourses. And if we bear in mind that for modernity worldviews and worlds tend to be identical, then there are as many possible worlds as there are discourses." (GODZICH, 1994, p. 362) ["Se uma mundivisão (visão de mundo) é um construto de discursivo, então deriva-se que há tantas mundivisões possíveis assim como há discursos. E se mantivermos em mente que para a modernidade visões de mundo e mundos tendem a ser idênticos, então, há tantos mundos possíveis quanto há discursos." Tradução Livre.]

${ }^{23}$ Nesse sentido, é curioso observar que a criação do Parque Nacional de Yellowstone, considerado um dos grandes marcos fundantes do discurso conservacionista que redundou no discurso ecológico contemporâneo, foi decorrência dessas expedições fotográficas pelo oeste americano: "An example of this contribution is the photographic work of William Henry Jackson, a photographer who had, prior to his appointment to the survey, been documenting the building of the Union Pacific Railroad as it journeyed westward to join the Central Pacific railroad. Jackson's images of the Yellowstone region accompanied sketches by Thomas Moran and a detailed report of the survey's findings. These were presented to the U.S. Congress, and on March 1, 1872 President Grant signed a bill making the region Yellowstone National Park." Disponivel em:

http://www.onlinenevada.org/u.s. geological and geographical surveys of the american west: the great surv eys Acesso em: 13 Mar. 2008. ["Um exemplo dessa contribuição é o trabalho fotográfico de William Henry Jackson, fotógrafo que esteve, antes do seu compromisso à pesquisa, documentando a construção da Ferrovia Union Pacific enquanto ela seguia atravessando o oeste para se unir à Ferrovia Central Pacific. As imagens de Jackson da região de Yellowstone acompanharam os esboços de Thomas Moran e um detalhado relatório dos resultados da pesquisa. Estes foram apresentados ao Congresso dos Estados Unidos, e em $1^{\circ}$ de março de 1872 , o Presidente Grant assinou uma lei que transformou a região no Parque Nacional Yellowstone ". Tradução Livre.]
} 
a representação de Natureza sofre saltos e a maneira como se opera a relação Homem-Meio permanece marcada por essa última reorganização "visual".

Krauss (1985) destaca, assim, a importância da relação da fotografia de paisagem com um documentar a natureza de acordo com um certo olhar sobre a natureza. A autora lembra, ainda, que as imagens fotográficas dos grandes levantamentos, bem como dos relatórios e estudos científicos do periodo, eram acompanhadas por versões das mesmas imagens em litografia ou croquis, o que facilitava o processo de reprodução por impressão. A comparação entre as litografias e as imagens fotográficas originais mostra uma série de modificações feitas nas primeiras. Na discussão que Krauss desenvolve, os autores citados entendem que a idéia de um Deus transcendental habitava as imagens fotográficas de O'Sullivan (e de alguns outros fotógrafos envolvidos nos grandes levantamentos geológicos do oeste norte-americano) de maneira muito mais marcante do que as cópias litográficas dessas mesmas fotografias (que costumavam acompanhar os relatórios cientificos fruto desses mesmos levantamentos geológicos).

Essa fruição do divino nas fotografias de O'Sullivan pode estar relacionada à reprodução de elementos estéticos da pintura do período romântico pelos fotógrafos de paisagem do final do século XIX e início do século XX, tal qual aponta Galassi (1981):

A invenção da fotografia é fruto da acumulação de experiências pictóricas, que
marcam o período crítico de transformação do procedimento normativo da
era de Uccello (séc. XV) para a era de Degas (séc. XIX) (GALASSI, 1981 apud
CARVALHO, 1990, p. 228)

A produção dos fotógrafos de paisagem que se vinculam ao pictorialismo valoriza o sensivel no sentido de ir contra a ordem imposta ao mundo pela premência do racionalismo, apontando a Natureza como lugar do Belo, do Verdadeiro, do Uno, como remissão ao Divino entendido como aquilo que comunga com a natureza uma existência completa. $\mathrm{O}$ discurso estético do romantismo na pintura invade e permeia as produções fotográficas sobre paisagem dos fotógrafos pictorialistas do periodo.

\footnotetext{
${ }^{24}$ GALASSI, Peter. Before Photography. Painting and the Invention of Photography. New York: The Museum of Modern Art, 1981. apud CARVALHO, 1990.
} 
Krauss (1985), entretanto, salienta o embate existente entre interpretações sobre o pictorialismo nas fotografias dos fotógrafos dos Great American Surveys:

The treatment of Western survey photography as continuous with painterly depictions of nature is everywhere in the literature. Barbara Novak, Weston Naef, and Elisabeth Lindquist-Cock are three specialists who see this work as an extension of the landscape sensibilities operative in American nineteenth-century painting, with transcendentalist fervor constantly conditioning the way nature is seen. Thus, the by-now standard argument about the King/O'Sullivan collaboration is that this visual material amounts to a proof-by-photography of creationism and the presence of God. King, it is argued, resisted both Lyell's geological records of the Utah and Nevada landscape as a series of acts of creation in which all species were given their permanent shape by a divine creator. The great upheavals and escarpments, the dramatic basalt formations were all produced by nature and photographed by O'Sullivan as proof of King's catastrophist doctrine. With this mission to perform, O'Sullivan's Western Photography becomes continuous with the landscape vision of Bierstadt or Church.

There is equal support for the opposite argument: King was serious scientist, who made great efforts to publish as part of the findings of his survey Marsh's palaeontological finds, which he knew full well provided one of the important "missing links" needed to give empirical support to Darwin's Theory. (KRAUSS, 1985, p. 134; grifos nossos) ${ }^{25}$

Parece que o testemunho cientifico, ou seja, o testemunho da verdade (no caso, a verdade da evolução como agente das diferenças existentes na natureza em detrimento da criação divina) opera de maneira bem mais neutralizada nas litografias e desenhos que ilustram os relatórios geológicos do que nas fotografias que acompanham esses mesmos relatórios. A fotografia de paisagem do final do século XIX parece oferecer a experiência da fruição da criação divina porque vinculada a formas pictóricas de representação artísticas. Tendo em vista as premissas do Transcendentalismo norte-americano, é possivel pensar-se que o "divino" pressuposto nas

\footnotetext{
25 “O tratamento da pesquisa fotográfica Ocidental como contínuo com as descrições pictóricas da natureza está em toda parte na literatura. Barbara Novak, Weston Naef, e Elisabeth Lindquist-Galo são três especialistas que vêem esse trabalho como uma extensão das sensibilidades operativas da paisagem na pintura americana do século dezenove, com fervor de transcendentalista constantemente condicionando a e maneira que a natureza é vista. Assim, o argumento padrão, atualmente aceito, sobre a colaboração King/O'Sullivan é de que esse material visual eleva-se a uma prova-por-fotografia do creacionismo e a presença de Deus. King, argumenta-se, opunha-se a ambos os registros geológicos de Lyell sobre Utah e sobre a paisagem de Nevada, entendendo-as como uma série de atos da criação em que todas as espécies foram dadas em sua forma permanente por um criador divino. As grandes dobramentos, falhas e escarpas, as formações dramáticas de basalto, eram todas produzidas pela natureza e fotografado por O'Sullivan como prova da doutrina catastrofista de King. Com esta missão para executar, a Fotografia Ocidental de O'Sullivan torna-se contínua com a visão de paisagem do Bierstadt ou a da Igreja. Há apoio igual para o argumento oposto: King era cientista sério, que fez grandes esforços para publicar como parte dos seus resultados,os achados paleontológicos da pesquisa de Marsh, a qual ele sabia muito bem que fornecia um dos importantes "elos perdidos" necessários para dar apoio empírico à Teoria de Darwin. Tradução livre.
} 
imagens de O'Sullivan remontariam à unidade da Natureza como morada do Homem e o direito de existir de todas as espécies vivas porque são, também, expressão do divino. Há uma diferença, ainda que sutil, entre assumir o direito à vida de tudo o que faz parte "do natural", remeter essa assunção a um valor "sagrado" e afirmar "Deus sive natura" como no Monismo Alemão. Parecem ser visões da unidade na Natureza com vetores contrários: o Romantismo Alemão traz Deus para dentro da Natureza, enquanto o Transcendentalismo Americano carrega o Homem para o espaço do natural e toda a ética ao redor dos direitos humanos e civis para esse espaço do animado e inanimado não-humano.

Por outro lado, o que Krauss (1985) considera como sendo característica de neutralidade e objetividade das demais expressões artísticas manuais do periodo, - o desenho (croquis), a litografia, e a xilogravura, usados para acompanhar os relatórios dos Grandes Levantamentos Norte-Americanos -, para nós é apagamento da escritura originalmente inscrita nessas técnicas manuais.

A fruição mística na imagem técnica mecânica estaria, assim, mais relacionada à magia mística das imagens técnicas que se produzem sem o instrumento da escritura. É possivel que o clicar da máquina fotográfica seja de tal maneira distante da escritura que seja possivel uma ascendência do místico enquanto mágica e não enquanto voz de uma lei. A alegada "neutralidade" das técnicas escriturais seria o verdadeiro simulacro da escritura, o apagamento em evidência por uma metafísica de natureza diferente, pois se esconde na "letra" do desenho e da gravura, que ainda não é fonética, mas que se produz dentro de uma formação discursiva fonetizável e fonetizante. A neutralidade pressuposta nos desenhos e croquis seria, então, ilusória.

Retomando a noção heideggeriana do termo representação, a fotografia sobre paisagem parece também mostrar o embate entre essas duas mundivisões ou representações de mundo. De um lado a Ciência como empresa moderna que opera o progresso humano (gesto de busca); de outro, a persistência de um espírito transcendental pictorialista como única maneira de retratar "o drama humano, os amores trágicos, os ideais utópicos, os desejos de escapismo" (gesto fotográfico). A objetividade da razão versus a subjetividade do lirismo e da emoção. A fotografia de paisagem encerra, em si mesma, o conflito entre escritura e magia técnica. Essa contradição interna, essa 
disputa constitutiva entre os elementos antagônicos que compõem a imagem fotográfica sobre a paisagem, persiste e insiste nas fotografias que são produzidas tendo o Protocolo de Kyoto como "pauta".

Um outro aspecto relevante, notado por Krauss e salientado por Trachtenberg, é a relação que essas imagens fotográficas podem ou não ter com os textos que as acompanham. No texto, Trachtenberg afirma que, "when viewed outside the context of the reports it accompanied [the photography] seems to perpetuate the landscape tradition." Isto é, tanto o texto escrito, como a formação discursiva na qual ela se insere (o discurso estético, o cientifico, o jornalístico) organizam, validam e legitimam a fotografia de paisagem como um estilo fotográfico com usos especificos. Há, necessariamente, em todo conjunto de fotografias, uma conexão contextual fundamental que representa a presença do discurso estético, do discurso cientifico e do discurso jornalístico ao qual a imagem técnica mecânica dá apoio ou se sobrepõe, como veremos mais adiante.

Essa maneira de olhar a natureza, pela fotografia, iniciada ao redor de 1860, nos Estados Unidos, mistura vários elementos, por si mesmos, já bastante complexos: 1) o novo valor estético modernista, advindo da pintura do final do século XIX; 2) o valor documental e de verdade do racionalismo cientifico, em vigor desde a revolução copernicana do século XVI; e 3) o valor mistico e utópico, proveniente do Romantismo na pintura e na literatura, ainda presentes na estética da produção imagética do final do século XIX.

Dessa forma, o fazer jornalístico sobre o Protocolo de Kyoto, além de transportar o discurso estético do plano, contido na fotografia, em geral, e na fotografia sobre a paisagem, em especifico, para o espaço de exibição do discurso sobre a verdade dos fatos, também transporta essa nova representação, essa nova visão de mundo, entendido como resultado da atividade cientifica. A fotografia sobre paisagem, além de representar um discurso estético - a visão de mundo modernista, representa, também. E, no processo de produção do discurso sobre a notícia, a fotografia sobre paisagem passa a ser selecionada positiva ou negativamente em função de sua adequação a esse discurso. 
É nessa operação, nesse jogo, que se constitui um embate desequilibrado entre enunciados distintos - o da Estética, o da Ciência, e o da Notícia -, que a fotografia sobre paisagem, ou seja, a fotografia sobre o Protocolo de Kyoto, se insere.

\section{3 :: Ato e gesto: camadas distintas da produção do fotográfico ::}

Dubois (2004) compreende o ato fotográfico como um processo que se inicia com o fotógrafo e termina no observador "final" da foto, em geral, exposta na parede de algum museu, já que a fotografia, como Arte, define em si mesma um valor final de obra enquanto tal. Porém, com a ampliação da presença da fotografia em inúmeros tipos de veículos de informação, há outros "espaços de exibição", que definem a legitimidade da imagem fotográfica como "verdade" artística ou "verdade" documental.

Flusser (1994), por sua vez, define o gesto fotográfico como parte de uma teoria geral dos gestos:

Los gestos son movimientos del cuerpo que expresan uma intención. (...) Cuando levanto el brazo y alguien me explicaque eso es el resultado de determinadas causas físicas, fisiológicas, psicológicas, sociales, económicas, culturales, etc., yo aceptaré su explicación. Mas no me sentiré satisfecho con ello. Y es que estoy convencido de que levanto el brazo porque quiero y que, no obstante todas esas causas indudablemente reales, no lo levantaría si no quisiera. Por eso el levantamiento del brazo es un 'gesto'. El gesto es um movimiento del cuerpo, o de um instrumento unido a él, para el que no se da ninguna explicación causal satisfactoria. Y defino asimismo lo de 'satisfatorio': en el discurso es el punto, que no necesita de ninguna discusión ulterior. (FLUSSER, 1994, p. 8)

O gesto fotográfico, assim, é o gesto de movimento que o fotógrafo executa, munido de câmera fotográfica, "cercando" e buscando o momento do clique (ou momento decisivo, como denominou Cartier-Bresson ${ }^{26}$ ). O gesto fotográfico é, assim, o momento da produção de cada instantâneo, de cada fotograma. É a fotografia na duração. É a irrupção do inconsciente em seu contato com a intencionalidade do artista. Choque entre pulsão, atávica, inacessivel, de morte

\footnotetext{
26 "(...) the celebrated French photographer Henri Cartier-Bresson lay in wait for all the messy contingency of the world to compose itself into na image which he judged to be both productive of visual information and aesthetically pleasing. This he called 'the decisive moment', a formal flash of time when all the right elements were in place before the scene fell back into its quotidian disorder." (PRICE, 2000, p. 88)
} 
ou de vida, e os discursos operatórios que, no campo do racional (nem sempre consciente), orientam essa busca e essa movimentação do fotógrafo dentro da cena que pretende recortar da linha do tempo em clique de congelamento. O gesto fotográfico opera, assim, o brinquedo (FLUSSER, 1983) como atualização de uma relação não percebida entre movimentos, decisões e escolhas conscientes e inconscientes, caracterizados, respectivamente, pela busca de elementos que serão recortados da cena e pelo automatismo ${ }^{27}$ da decisão do clique. O fotógrafo pode "afundar-se" tanto num, quanto no outro. São opostos que interagem continuamente e que caracterizam o gesto fotográfico.O brincar com a câmera, como se fotografar fosse jogo (FLUSSER, 1983) se dá no gesto fotográfico. Na decisão pelo clique, expressa-se, também, toda a responsabilidade de um ethos do gesto fotográfico.

A observação do fotograma produzido pelo gesto fotográfico é também gesto, mas de outra natureza, já que ele não dispõe de "clique". O gesto de observação pode levar, entretanto a outro gesto fotográfico: ao avistar a imagem na tela de computador clica-se para "salvá-la" ou para transferi-la a um programa de edição de imagens fotográficas. Cada clique no teclado do computador é um gesto muito similar ao fotográfico: o "editor" busca evidenciar algo na imagem, quer alterá-la e nesse movimento, dá continuidade ao ato fotográfico.

O ato fotográfico deixa de ser, então, esse processo eminentemente restrito ao artístico como discurso de validação estética e torna-se um “ecossistema de gestos”. Uma longa cadeia de gestos fotográficos em que os aparelhos (câmeras, celulares, computadores etc) são brinquedos e executam programas, enquanto o fotógrafo/editor (profissional ou amador) de imagens executa

\footnotetext{
27 No filme "Antes da chuva" (Before the rain, 1994), de Milcho Manchevski, Aleksandar é um fotógrafo atormentado por acreditar que sua máquina fotográfica causou a morte de um refém de guerra, literalmente. Sua ânsia por uma imagem sobre a morte faz com que um guerrilheiro atire para que Aleksandar registre o momento do impacto da bala na cabeça de um prisioneiro. Em outra cena, em que está no vilarejo em que nasceu, um homem morre e a mão de Aleksandar desliza para diante de seu rosto, como se empunhasse uma máquina fotográfica imaginária, e seu dedo dispara um clique invisível, autômato, como se seu olhar sobre o mundo e em especial, sobre a morte, fosse o olhar mecânico da lente, maquinal, desprovido de emoção ou isento de intenção. Como se seu existir e sentir, seu relacionar-se com o mundo, dependesse do gesto que registra, do ato que congela a cena e permite que ela permaneça, apesar do tempo. Em outro filme, "Tudo acontece em Elizabethtown" (Elizabethtown, 2005), de Cameron Crowe, a personagem de Kirsten Dunst também simula o momento do clique, toda vez que uma determinada cena lhe parece única, como se o gesto, mesmo sem a câmera, fosse capaz de reforçar e antecipar por si mesmo o potencial de memorização, de congelamento do tempo e de recorte da cena. Ainda, em "Janela da Alma" (2002), documentário de João Jardim e Walter Carvalho, Win Wenders enfatiza que seu olhar fotográfico deve-se ao hábito de ver o mundo em quadros, propiciado pela grossa armação dos óculos que usa desde muito pequeno. Mais que as lentes, é o enquadramento do mundo por meio da estrutura dos óculos que, segundo Wenders, the permite ver.
} 
“cliques", faz escolhas e publica a imagem em espaços de exibição, não mais restritos à lógica do discurso estético.

Chamamos "ecossistema de gestos" porque os brinquedos produtores de gestos fotográficos aos quais nos referimos não podem disparar seus obturadores na ausência completa de dedos humanos. A relação dos dedos com os aparelhos é, também, exposta por Flusser:

[Os dedos] não se movimentam maquinalmente, embora se movimentem dentro e sobre várias "máquinas" (a de escrever, o alfabeto, a língua portuguesa). O seu movimento é deliberado, isto é, articula minha liberdade. (...) A cultura é natural para os dedos, e fora dela os dedos não são o que devem ser: livres. (FLUSSER, 1979, p. 65) ${ }^{28}$

Essa combinação "olho-dedo-brinquedo" é a unidade mínima desse nosso ecossistema ${ }^{29}$, a promover congelamento da cena no gesto fotográfico e paralização da temporalidade na qual o fotógrafo está imerso, ao mesmo tempo em que, no momento do gesto de observação do fotograma, a temporalidade é circular, "eterno retorno", no dizer de Flusser.

A temporalidade do gesto fotográfico é o instante; a do gesto de observação é circular e a do ato fotográfico "tende ao infinito", uma vez que a "manipulação" dos fotogramas, uma vez “engolidos" pelos veículos de informação, perdem o "registro" do gesto que os produziu.

$\mathrm{O}$ ato fotográfico tornado infinito, distancia cada vez mais o momento do primeiro clique, o clique óptico da unidade "olho-dedo-brinquedo" original. Nem mesmo noções como obturador e velocidade da captura da imagem têm, de fato, qualquer significação estática. Os programas

\footnotetext{
${ }^{28}$ Como proposto por Andy Clark, para quem o fato de nos utilizarmos de sistemas computadorizados diversos, como notebooks, telefones celulares, GPSes e PDAs já é indicativo de que nossas mentes estão cada vez menos dentro de nós mesmos, dentro de nossos cérebros. Nas palavras dele, "the mind is just less and less in the head". E essa convergência para uma mente biotecnológica nos configuraria já como ciborgues. A mesma idéia parece em Gunter Anders: "[...] Naturalmente podemos utilizar a TV com a finalidade de participar numa missa. O que, queiramos ou não, tão fortemente nos "marca" ou "transforma", como a própria missa, é o öato de que exatamente não participamos dela, mas consumimos apenas sua imagem. Este efeito de livro ilustrado, entretanto, é claramente diferente não apenas do "intencionado", mas é seu contrário. O que nos marca e desmarca, o que nos forma e deforma, não são apenas os objetos transmitidos pelos "meios", mas os próprios meios, os próprios aparelhos: que não são apenas objetos de possiveis usos mas já fixam, através de suas estrutura e função firmemente determinadas, seu uso e com isso o estilo de nossa ocupação e nossas vidas, em resumo, de nós.(100)" Disponivel em: http://www.eca.usp.br/nucleos/filocom/home.html Acesso em 19 Jun. 2006.

29 Mesmo os satélites produtores de imagens precisam de programas para dispararem o obturador automaticamente: a decisão de dispará-lo não é gesto da máquina. Foi preciso que um dedo definisse em seu programa a freqüência de cada "clique". A fotografia por satélite seria um caso extremo de distanciamento entre o olho que vê, o dedo que clica e o brinquedo que registra.
} 
tecnológicos digitais podem alterar essas concepções físicas do procedimento fotográfico analógico/mecânico. Esse brincar com a luz, as cores, as sombras, os traços, a nitidez da imagem fotográfica provoca "movimentos" no suposto congelamento de tempo tradicionalmente atribuido à imagem fotográfica.

A partir do momento que uma imagem fotográfica é gerada ela entra no processo ininterrupto de sucessão de gestos fotográficos. Assim, ao abrirmos o jornal, a revista, a página da Internet, não vemos o gesto fotográfico, mas o processo do ato fotográfico em andamento. $O$ ato fotográfico opera o resultado do gesto fotográfico enquanto jogo e atualização no espaço de exibição de cada tipo de veículo de informação. O fotógrafo precisou percorrer o campo/cena em performance única de olho-dedo-brinquedo para selecionar os cortes, capturá-los em uma série de cliques que foram analisados na tela do computador ou no estúdio fotográfico. Os melhores resultados na sua opinião foram encaminhados a um fotógrafo em "outro nivel da cadeia/ecosssitema de gestos" (editor de fotografia, agência de notícias, curador de exposição, juiz de concurso fotográfico etc), que com sua "experiência" de olho-dedo-brinquedo realizou mais um gesto para decidir qual das imagens fotográficas iria ser exibida no espaço de legitimação de uma verdade documental ou estética.

Cada gesto de observação pode, assim, gerar um novo gesto fotográfico que a unidade olhodedo-brinquedo opera. O gesto fotográfico é gesto inerente ao processo mais amplo do ato fotográfico. Para o fotojornalismo sobre meio ambiente, entretanto, o momento do clique ou momento decisivo, é um gesto fotográfico complexo porque atende a uma expectativa, uma demanda, um uso potencial da imagem a ser "consumida" pelo ato fotográfico. Por isso, nunca há neutralidade no gesto fotográfico nem no ato fotográfico. Ambos estão imbuídos dos discursos discursos técnicos, científicos, políticos, estéticos, jornalísticos que organizam a sociedade contemporânea e é nesse sentido que a fotografia representa: um fotograma em pixels pode sempre tornar a ser gesto fotográfico dentro do "ecossistema de gestos" e ter o seu "por-se em imagem" alterado, re-apresentado e re-presentificado. Gesto e ato fotográficos são, assim, a um só tempo, operadores e operados da representação. 


\section{:: Referências bibliográficas ::}

BENJAMIN, Walter. A obra de arte na era de sua reprodutibilidade técnica. In:

Obras escolhidas: Magia e técnica, arte e politica. São Paulo: Brasiliense, 1996. p. 165-196.

BENVENISTE, Émile. Problemas de Lingüística Geral. Campinas: Pontes, 1995.

BURKE, Peter. Testemunha ocular. História e Imagem. Bauru: EDUSC, 2004.

DELEUZE, Gilles. A imagem-tempo. São Paulo: Brasiliense, 2005.

Lógica do Sentido. São Paulo: Perspectiva, 2003.

DUBOIS, Philippe. O ato fotográfico. Campinas: Papirus, 2005.

FABRIS, Annateresa. Redefinindo o Conceito de Imagem. Rev. bras. Hist., São Paulo, v. 18, n. 35, 1998. Disponivel em: http://www.scielo.br/scielo.php?script=sci arttext\&pid=S0102$\underline{01881998000100010 \& \operatorname{lng}=\mathrm{e} \& \& \mathrm{nrm}=\mathrm{iso}}$. Acesso em: 15 Mar. 2006.

FLUSSER, Vilém. Los gestos: fenomenología y comunicación. Barcelona: Herder, 1994. 1998.

Ensaio sobre a Fotografia. Para uma filosofia da técnica. Lisboa: Relógio D’Água, Naturalmente. Vários acessos ao significado de Natureza. São Paulo: Duas Cidades, 1979.

GODZICH, Wlad. Languages, Images and the Postmodern predicament. In: GUMBRECHT, Hans Ulrich and PFEIFFER, K. Ludwig. Materialities of Communication. Stanford: Stanford University Press, 1994. p. 355-370.

HEIDEGGER, Martin. O tempo da imagem no mundo. In: Caminhos de Floresta. Lisboa: Fundação Calouste Gulbenkian, 1998. p. 95-138.

KRAUSS, Rosalind E. Photography's Discursive Spaces. In: KRAUSS, Rosalind. The originality of the Avant-Garde and Other Modernists Myths. Cambridge: MIT Press, 1985. p. $131-150$

HENNING, Michelle. The subject as object: Photography and the human body. In: WELLS, Liz (ed.) Photography: A Critical Introduction. New York: Routledge, 2000. p. 219-250.

PRICE, Derrick. Surveyors and surveyed: Photography out and about. . In: WELLS, Liz (ed.) Photography: A Critical Introduction. New York: Routledge, 2000. p. 65-115.

VIRILIO, Paul. A máquina de visão. Rio de Janeiro: José Olympio, 2002. 


\section{Capítulo 3 :: Gesto fotográfico e o Protocolo de Kyoto ::}

$1::$ Kyoto - discurso, texto e escritura ::

2 :: A constituição das Séries sobre Kyoto ::

3 :: As Séries - imagens-informação ::

4. :: O "fora" das Séries - imagens-sensação ::

5 :: $\mathrm{O}$ gesto fotográfico sobre Kyoto ::

:: Referências bibliográficas ::

:: Série Tubos ::

:: Série Branca ::

:: Série Girassóis ::

:: Imagens-sensação ::

\section{1 :: Kyoto - discurso, texto e escritura ::}

O Protocolo de Kyoto é um acordo internacional ${ }^{1}$ nascido de discussões e negociações sobre a questão climática, na 3a Conferência das Partes da Convenção-Quadro das Nações Unidas sobre Mudanças Climáticaš ${ }^{2}$, realizada na cidade de Kyoto, no Japão, em 1987. O acordo conta, atualmente, com a ratificação de 175 paises, e tem como objetivo o estabelecimento de metas de redução de emissões de gases estufa ${ }^{3}$.

\footnotetext{
${ }^{1}$ A versão integral, em português, do Protocolo de Kyoto está disponivel no Anexo I deste trabalho.

${ }^{2}$ Em inglês, UNFCCC - United Nations Framework Convention on Climate Change.

3 “Os gases do efeito estufa (GEE) são substâncias gasosas que absorvem parte da radiação infravermelha, emitida principalmente pela superfície terrestre, e dificultam seu escape para o espaço. Isso impede que ocorra uma perda demasiada de calor para o espaço, mantendo a Terra aquecida. (...) Dentre estes gases, estão o dióxido de carbono $\left(\mathrm{CO}_{2}\right)$, o metano $\left(\mathrm{CH}_{4}\right)$, o óxido nitroso $\left(\mathrm{N}_{2} \mathrm{O}\right)$, Perclorofluorcarbonetos (PFCs ) e também o vapor d'água. (...) Entre os gases do efeito estufa que estão aumentando de concentração o $\left(\mathrm{CO}_{2}\right)$, o $\mathrm{CH}_{4}$ e o $\mathrm{N}_{2} \mathrm{O}$ são os mais importantes. Os CFCs também têm a capacidade de reter a radiação infravermelha emitida pela Terra. Contudo, as ações para diminuir suas emissões [estabelecidas pelo Protocolo de Montreal] estão num estágio bem mais avançado, quando comparado com as emissões dos outros gases."

Disponivel em: http://pt.wikipedia.org/wiki/Gases_do_efeito_estufa Acesso em 10 Mar. 2008.
} 
A entrada em vigor do tratado ocorreu em 16 de fevereiro de 2005 com a adesão da Rússia à lista de países que assumem o compromisso de reduzir as emissões nacionais em, no mínimo, 5,2\% em relação às emissões medidas em 1990. Para entrar em vigor, o Protocolo precisou da ratificação de 55 países cujas emissões somadas correspondiam a 55\% das emissões de gases estufa naquele ano. A porcentagem de redução das emissões varia de acordo com o país industrializado listado no Anexo $I^{5}$ do Protocolo e os países que não conseguirem atingir suas metas de redução até 2012 não sofrerão qualquer tipo de sanção. Por isso, o Protocolo de Kyoto tem sido chamado de primeiro periodo de compromisso ${ }^{6}$, dentro das negociações da ConvençãoQuadro das Nações Unidas para as Mudanças Climáticas.

O Protocolo de Kyoto é, obviamente, o primeiro tratado internacional a impor metas dessa natureza, que implicam numa alteração tecnológica da produção capitalista sem igual na história dos tratados da ONU voltados para a questão ambiental. Por isso, é um acordo polêmico, cujas discussões políticas estão em cheque visto que mesmo que tais metas sejam alcançadas, já não se espera obter uma redução significativa do impacto das emissões de gases estufa sobre um conjunto de fenômenos naturais cujos processos de transformações, por terem sido desmistificados pela Ciência, são referidos, genericamente, como sistema climático global.

Central nas discussões ambientais atuais, o Protocolo de Kyoto é um texto que mobiliza significações discursivas ao redor de algumas noções que lhe são "fundantes": o principal gás estufa, o dióxido de carbono, é emitido por processos industriais que se utilizam de combustiveis fósseis para gerar energia elétrica e trabalho mecânico, e se acumula, velozmente, na atmosfera terrestre, acelerando, dramaticamente, o efeito estufa?

\footnotetext{
${ }^{4}$ Com a ratificação da Rússia, a cláusula que exigia como condição de vínculo legal do acordo o alcance de um mínimo de 55\% das emissões de CO2 em 1990 das Partes inclusas no Anexo I foi satisfeita e o tratado pôde, então, entrar em vigor.

${ }^{5}$ Os países (ou 'Partes') inclusas no Anexo I correspondem aos países-membros da OECD e aos países do antigo bloco soviético, que são chamados de paises em transição para economia de mercado.

${ }^{6}$ Do ponto de vista da escritura do direito internacional, o Protocolo de Kyoto é, de fato, uma emenda ("amendment", em inglês) à Convenção-Quadro da ONU, e por isso tem força de lei (é "legally binding", em inglês), diferentemente de Resoluçōes, que funcionam como recomendaçōes e não produzem compromissos legais entre as partes envolvidas.

7 O efeito estufa é um fenômeno natural que ocorre desde a formação da Terra. Ele é necessário para a manutenção da vida no planeta, pois, calcula-se que, sem ele, a temperatura média da Terra seria $33^{\circ} \mathrm{C}$ mais baixa, impossibilitando a vida no planeta, tal como conhecemos hoje. Disponível em: http://pt.wikipedia.org/wiki/Gases do efeito estufa Acesso em 10 Mar. 2008.
} 
Este fenômeno natural está agora "sem controle". Sua aceleração "exponencial” sugere que transformações na superfície do planeta que poderiam ocorrer dentro de períodos de tempo muito mais longos, estão em curso agora, no momento em que pensamos sobre elas ${ }^{8}$. Esse conjunto de fenômenos naturais sobre os quais Homem e demais seres vivos eram, até então, capazes de perceber ritmos e orientar seu trabalho/atividade sofre perturbações permanentes devido ao aumento do grau de entropia provocado pela acumulação acelerada dos gases estufa na atmosfera terrestre. A repetição das estações do ano, das temperaturas máximas e mínimas, dos periodos de estiagem e de monções são o que existia, ainda, como um certo vínculo do Homem civilizado - urbano, rural ou marítimo - com o que lhe resta de "natural" ou de atávico. O pescador e o agricultor têm percepções sobre o clima que respeitam esses ciclos padronizados que estão, agora, erráticos. Essa percepção do clima é base da existência e da sobrevivência de dezenas de milhares de seres vivos que orientam vários de seus comportamentos como coorte, acasalamento e migração por meio de um determinado padrão climático agora alterado.

Assim, o Protocolo de Kyoto representa uma expectativa de desenvolvimento, que constituida discursivamente, institucionaliza e atualiza o Projeto Moderno/Iluminista pelo qual "igualdade, liberdade e fraternidade” só podem ser alcançadas graças ao progresso humano, tecnológico e científico. A formação discursiva da qual faz parte - o discurso ecológico - propõe uma nova cidadania, entendida como "cidadania planetária".

Estão, assim, postas, tanto a crença na unidade Homem-Natureza e a coesão da Humanidade por um objeto comum - um sistema climático "sadio", e a escritura como único "método" científico e filosófico para se atingir esse arrojado projeto sócio-econômico cultural mundial.

Reproduzindo que engendrados nessa situação, estão os veículos de informação que fazem circular, também, imagens fotográficas sobre o esse modelo disciplinatório moderno.

\footnotetext{
8 "Historicamente, os países industrializados têm sido responsáveis pela maior parte das emissões globais de gases de efeito estufa. Contudo, na atualidade, vários países em desenvolvimento, entre eles China, Índia e Brasil, também se encontram entre os grandes emissores. No entanto, numa base per capita, os países em desenvolvimento continuam tendo emissões consideravelmente mais baixas do que os países industrializados. Na fonte da emissão também pode se observar um padrão global. Enquanto a maior parte das emissões decorrentes da queima de combustiveis fósseis ( $75 \%$ das emissões globais de $\mathrm{CO}_{2}$ ) provém dos países industrializados, as emissões decorrentes das mudanças no uso da terra $\left(25 \%\right.$ das emissões globais de $\left.\mathrm{CO}_{2}\right)$ tem como seus maiores responsáveis os países em desenvolvimento.” Disponivel em: http://pt.wikipedia.org/wiki/Gases_do_efeito_estufa Acesso em 10 Mar. 2008.
} 
No percurso lógico-linear explicativo os processos da escritura, do texto, e normativo do discurso ecológico como formação discursiva, as significações sobre as relações de causa-efeito típicas do pensamento lógico-dedutivo no qual se enquadra o Protocolo de Kyoto "encadeiam-se" no processo informativo: as emissões de dióxido de carbono são responsáveis pelo aceleramento do aquecimento global que altera o padrão climático. Este, por sua vez, desorganiza os sistemas naturais e artificiais (bem como os seres vivos que os compõem) que coexistem sobre a superfície do planeta, ameaçando sua sobrevivência/permanência. Esse "estado-da-arte" consegue ser representado no espaço de legitimação da notícia por meio do texto jornalístico, mas será que, também, por meio das imagens que os acompanham?

Acreditamos que seja a insistência da escritura que dá significação ao fotojornalismo sobre o Protocolo de Kyoto. Porque inseridas em espaços discursivos - quer estéticos (da parede do museu), quer noticiosos (do veículo de informação) todas as imagens fotográficas modernas dependem da escritura para significar?

(...) the putatively autonomous 'language of photography' is never free from the determinations of language itself. We rarely see a photograph in use which does not have a caption or a title, it is more usual to encounter photographs attached to long texts, or with copy superimposed over them. Even a photograph which has no actual writing on or around it is traversed by language when it is 'read' by a viewer (for example, an image which is predominantly dark in tone carries all the weight of signification that darkness has been given in social use; many of its interpretants will therefore be linguistic, as when we speak metaphorically of an unhappy person being 'gloomy'). ( BURGIN, 1982, p. 144)

Assim, a legenda ${ }^{10}$ e os textos que acompanham como escritura as fotografias produzidas para o espaço da notícia, produzem uma imposição de significação à imagem, desde niveis mais

\footnotetext{
${ }^{9}$ Nesse sentido, foi curiosa a atitude do site FreakyMartin.com que publicou, em 17 de janeiro de 2008, as 73 melhores fotos da MSNBC (Breaking World News and US News Stories and Headlines) sem incluir uma só legenda. A seqüência de fotos ganha uma força simbólica única e desconcertante, porque nega a possibilidade de explicação/significação que a escritura impõe, quando legenda. Para ver as imagens, visite: http://freakymartin.com/2008/01/17/the-best-photos-of-2007-msnbc-version-73-photos/

${ }^{10}$ As legendas das imagens em jornais, aliás, estão cada vez mais complexas. Apresentam um "título" e um subtítulo explicativo [exemplo] quase como se fossem manchetes da matéria que acompanha a fotografia. Passam a ser manchetes da "narrativa" subentendida pelos discursos que organizam a interpretação da imagem e que contribuem para a significação da mesma. A escritura e o discurso que ela tece, procuram, por meio da crença na neutralidade do relato jornalístico, enredar o leitor/observador da imagem numa única possibilidade de interpretação - a que é "correta", "verdadeira", claramente exposta pela imagem que documenta o fato, e pela explicação da imagem que encerra relações de causa-efeito capazes de justificar, além de "esclarecer" os acontecimentos narrados no texto jornalístico.
} 
"objetivos", como a presença de dêiticos ou de indicadores temporais e espaciais mais complexos, típicos da descrição noticiosa, até exposições mais analiticas.

Entendemos, então, que imagens estão cada vez mais dependentes de textos e à uma maneira de "interpretação" imposta pela lógica da "leitura" linear. A fruição, típica de processos artísticos, está subsumida pela penetração da estrutura e da lógica textual. É como se texto e imagem estivessem em constante conflito. Por isso a proposta deste trabalho de isolar as imagens de seus textos e contextos de origem, mantendo apenas o vínculo ao Protocolo de Kyoto como formação discursiva que motivou o gesto fotográfico de cada uma delas.

\section{2 :: A constituição das séries de Kyoto ::}

As imagens alvo deste estudo são associadas ao Protocolo de Kyoto pelo próprio veículo de informação, seja ele Portal de Internet de Agência de Notícias, versão digital de jornal, revista ou informativo de ONG, website de agências governamentais e não-governamentais; website de fotógrafos envolvidos com a questão ambiental.

As fotografias digitais foram obtidas e selecionadas a partir da Internet, pelo uso dos mecanismos de busca Google e Google Images. ${ }^{11}$ A maioria das imagens relaciona-se ao periodo entre 2000 e 2007 em que fatos importantes nas negociações e disputas politicas e econômicas em relação ao Protocolo de Kyoto ocorreram. É nesse recorte diacrônico que se insere a saída dos Estados Unidos do processo de negociação, em 2000, e a ratificação do Protocolo pela Rússia, em 2004, o que garantiu sua entrada em vigor em 16 de fevereiro de 2005.

Nesse contexto, as fotografias que se produzem para "acompanhar" ou "ilustrar" a divulgação do Protocolo de Kyoto são dos mais variados tipos: retratos de politicos-chave para o processo

\footnotetext{
${ }^{11}$ O Google (Google, Mountain View, CA, www.google.com) é o maior mecanismo de busca da Rede. Lançado em 1999, a indexação de páginas da Internet pelo Google chegou a mais de oito bilhões de documentos em 2005 - a contagem atualizada está sempre visível no pé da página principal do Google. O nome Google foi escolhido para representar a gigantesca quantidade de material disponivel na Internet. O termo vem da palavra "googol" que representa o número 1 seguido por 100 zeros. $O$ nome Google também é utilizado como verbo, em inglês: "to Google something" significa pesquisar algo na Internet utilizando-se do Google.
} 
de negociação, em especial, Bush e Putin, proferindo discursos ou cumprimentando-se; líderes agrupados ao redor de mesas durante as Conferências das Partes organizadas pela ONU; grupos de ativistas em protestos; reuniões plenárias do IPCC $^{12}$, florestas em chamas, enchentes, furacões, áreas desérticas ou o solo ressecado do leito de um rio que não existe mais.

As fotografias que nos interessam, no entanto, são aquelas que apresentam elementos em sua aparência que estão mais diretamente ligados às palavras do texto, ao contexto e às formações discursivas que operam o discurso ecológico e legitimam o Protocolo de Kyoto como um discurso sobre as mudanças climáticas. Esses elementos são: 1) o dióxido de carbono como causa, 2) o aquecimento global como efeito, 3) as fontes alternativas de energia como solução.

Para cada um desses três grupos de elementos, que compõem a complexidade discursiva sobre o Protocolo de Kyoto, correlacionamos Séries de imagens fotográficas.

As Séries baseiam-se na repetição, dentro da circularidade temporal de cada imagem, desses elementos componentes do discurso ecológico sobre Kyoto. Essa repetição foi considerada no processo de recorte, escolha e análise das imagens que se auto-definem como referências ao Protocolo.

Em primeiro lugar, as fotografias foram selecionadas considerando-se a indexação do Google Images ao se utilizar, no campo de busca, as seguintes palavras-chave:

Protocolo de Kyoto

Kyoto Protocol

Mudanças Climáticas

Mudança do Clima

\footnotetext{
${ }^{12} \mathrm{O}$ IPCC - Intergovernmental Panel on Climate Change (Painel Intergovernamental sobre Mudanças Climáticas) é um órgão científico que tem a tarefa de avaliar o risco das mudanças climáticas causadas pela atividade humana. Estabelecido em 1988 pela World Meteorological Organization - WMO (Organização Metereológica Mundial) e a United Nations Environment Programme - UNEP (Programa das Nações Unidas para Meio Ambiente PNUMA), o IPCC não realiza pesquisas, nem monitora o clima ou fenômenos relacionados ao clima. A principal atividade do IPCC é publicar relatórios especialis sobre tópicos relevantes para a implementação da UN Framework Convention on Climate Change - UNFCCC (Convenção-Quadro das Nações Unidas sobre Mudanças Climáticas). Em 2007, o IPCC dividiu o Prêmio Nobel da Paz com o ex-Vice Presidente dos Estados Unidos, Al Gore.
} 


\author{
Alterações Climáticas \\ Climate Change \\ Aquecimento Global \\ Global Warming \\ Efeito estufa \\ Greenhouse effect
}

Obviamente, tais palavras-chave foram escolhidas considerando os elementos 1), 2) e 3) anteriormente mencionados. Essas relações de causa-efeito são fundamentais à natureza das formações discursivas que constituem os agenciamentos ${ }^{13}$ de subjetividades ao redor da temática da sustentabilidade. Dessa forma, os elementos comuns a cada uma das séries "fazem lembrar" esse aspecto do discurso científico, que as fotografias por si mesmas não podem "dizer" nem "comprovar".

As imagens produzidas por fotojornalistas são utilizadas por diversos meios nacionais e internacionais (websites de jornais, portais de Internet, versões online de noticiosos, versões virtuais de jornais impressos, websites de ONGs ambientalistas) para se referir diretamente ao Protocolo ou ao seu processo de negociação.

A fotografia do fotojornalismo possui caracteristicas mercantis peculiares ao sistema capitalista de produção da notícia. Elas são produzidas e distribuidas numa velocidade diária muito maior que qualquer outro tipo de fotografia. Não estamos mais na década de 30, do século passado, quando Dorothea Lange dependia de financiamento do governo e tinha apenas a possibilidade material de uma média de cinco a dez fotogramas por cena. A tecnologia permite que o

\footnotetext{
13 "Guattari e Rolnik (1996) definem agenciamento como uma "noção mais ampla do que a de estrutura, sistema, forma, etc. Um agenciamento comporta componentes heterogêneos, tanto de ordem biológica, quanto social, maquínica, gnosiológica, imaginária". (p. 317) Mais à frente, afirmam: "as máquinas, consideradas em suas evoluções históricas, constituem (...) um phylum comparável ao das espécies vivas. Elas engendram-se umas às outras, selecionam-se, eliminam-se, fazendo aparecer novas linhas de potencialidades. (...) no sentido lato (isto é, não só as máquinas teóricas, sociais, estéticas etc.), nunca funcionam isoladamente, mas por agregação ou por agenciamento. Uma máquina técnica, por exemplo, numa usina, está em interação com uma máquina social, uma máquina de formação, uma máquina de pesquisa, uma máquina etc." $\mathrm{O}$ desejo é maquínico porque ele produz, é criativo, agencia elementos. Não podemos reduzir essa concepção de desejo ao simples maquinismo, como uma herança de algum tipo de racionalismo ou como uma metáfora de apologia ao mecânico como algo superior ao humano" (p. 320)." Disponivel em http://www.uff.br/geographia/rev_07/rogerio7.pdf Acesso em 04 Mai 2008.
} 
fotógrafo passe de 1000 fotogramas utilizando-se de uma câmera digital reflex com memória flash $^{14}$ e ainda que ele "apague" resultados insatisfatórios no momento seguinte ao momento do clique. Assim, o fotógrafo vai "a campo" e, num recorte de tempo de algumas horas, pode clicar de uma a centenas de fotogramas, dependendo da cena (tema) que orienta seu gesto fotográfico do qual apenas um fotograma será selecionado para publicação no espaço de legitimação da notícia. As séries ${ }^{15}$ de fotografias construidas nesta pesquisa nasceram dessas constatações operatórias do fotojornalismo contemporâneo.

Diferente do discurso estético, que valoriza uma narrativa composta por vários cliques, o discurso da notícia prega o valor do spot news ou do breaking news. Um clique precisa conter o máximo de elementos descritivos (e portanto, lingüisticos) que se relacionem com a notícia. A expectativa é que o meio fotográfico seja capaz de sintetizar a notícia inteira em apenas um enquadramento. Daí a ação típica do fotógrafo: não basta um clique; é preciso uma quantidade maior para se ter certeza de que toda a informação que corresponde ao texto estará contida naquela imagem. Não à toa, o repórter fotográfico vai a campo com uma pauta já em mente. Sua fotografia é então "pautada" por um valor de notícia, além do estético. Para o fotojornalismo, entretanto, o discurso estético estaria em um segundo plano de importância ${ }^{16}$ quando comparado ao valor documental da imagem fotográfica.

A viagem pelas fotografias é um percurso por diversos gestos fotográficos que buscaram caracterizar idéias ou noções a respeito da conexão entre o clima, a ação do homem e os resultados sobre a performance alterada dos ciclos biogeoquímicos do planeta. Essa “miscigenação" entre as significações das palavras e os processos discursivos no qual o gesto fotográfico está inserido acaba sendo percebida pela maioria do público leigo como a constituição de noções sinônimas, muitas vezes por meio de "derivações metonímicas" que

\footnotetext{
${ }^{14}$ Os novos cartões com tecnologia compact flash desenvolvidos para as câmeras reflex digitais são capazes de armazenar até 32 gigabytes de imagens em velocidades até 500 vezes superior à velocidade de uma máquina fotográfica analógica reflex.

15 Essa noção da série fotográfica é de tal forma importante para a análise do trabalho fotográfico em fotojornalismo que o achado da "mala mexicana" com os negativos de Robert Capa, em janeiro de 2008, foi tratado quase como descoberta arqueológica pelos Historiadores da Arte e da Fotografia Modernas.

${ }^{16}$ Acumulam-se casos nas editorias de imagem das redações em que fotografias tiveram sua publicação negada porque apresentavam mais elementos estéticos do que propriamente valor de notícia. $O$ que parece uma contradição tendo em vista os critérios subjetivos, em termos da combinação desses dois conjuntos de elementos complexos, mas supostamente opostos, e que entram em consideração nas premiações do Pulitzer, do World Press Photo Contest e do Robert Capa Gold Medal, para citar apenas alguns prêmios tradicionais de fotojornalismo.
} 
levam a equiparar "Mudança Climática", "Aquecimento Global", "Protocolo de Kyoto" e "Poluição do Ar".

Cada um dos fotogramas escolhidos é parte de uma sessão de gestos fotográficos cujo histórico não temos. Só temos acesso à parte do ato fotográfico que validou cada fotograma como exemplo de fotojornalismo. Ao compor uma seleção de fotogramas, simulando a função de um curador $^{17}$, propomos um novo gesto de busca (que se distancia de métodos de pesquisa tradicionais), "forjando" ou "supondo" a sessão original, por meio do registro do gesto que é cada fotograma. As séries correspondem a conjuntos de gestos fotográficos legitimados como notícia sobre a temática da sustentabilidade inscrita no Protocolo de Kyoto.

Assim, a atividade de seleção de fotografias e organização das mesmas para os objetivos desta pesquisa, configura-se como expressão do ato fotográfico envolvido na produção, utilização e circulação de cada uma dessas imagens. O uso de fotogramas impressos nesta pesquisa não é, pois, gesto fotográfico em si mesmo, mas um gesto de busca que atualiza, dentro do ato fotográfico, o processo infinito e inerente à cada gesto fotográfico.

As séries de fotogramas são, assim, testemunhas do gesto fotográfico, enquanto o fotograma único, escolhido para circulação, é testemunha do ato fotográfico. Somente a este último temos acesso: ele é fragmento do gesto, que esfacelado, só pode remeter a fragmentos da cena, do todo que existia diante da câmera antes de ser recortado por ela. O fotógrafo ou funcionário (FLUSSER, 1985) é um seeder, num sentido similar ao da cultura digital ${ }^{18}$; ele é semente propriamente dita, portador do potencial do gesto que se atualiza em fotograma. Ao reproduzimos versões impressas dos fotogramas utilizados nesta pesquisa, somos também um tipo de seeders por estarmos "promovendo" a circulação do gesto fotográfico que originou essas imagens fotográficas, ao mesmo tempo em que nos "apropriamos" delas para atualizar sua "interpretação".

\footnotetext{
17 "Um curador é um agente cultural que trabalha para que as artes visuais criem um espaço público de reflexão sobre questões contemporâneas.”

Disponivel em: http://forumpermanente.incubadora.fapesp.br/portal/.event_pres/workshops/folder.2005-0620.3748870081/oficina_chus/Acesso em: 03 Mai. 2008

18 Um "seeder" ("semeador") é alguém que contribui para um "torrent" ou programa P2P (programas de compartilhamento de arquivos entre vários usuários da Internet). Basicamente, qualquer pessoa que se utilizar de um programa desse tipo torna-se um "seeder", pois esses programas são configurados para compartilhar tudo o que for "baixado" da Internet, apesar disso poder ser alterado pelo usuário.
} 


\section{3 :: As Séries - imagens-informação ::}

As fotografias que compõem as Séries constituidas para nosso estudo parecem repetir uma certa maneira de olhar e pensar a ilustração de Kyoto. Um primeiro grupo de imagens fotográficas parece representar, sistematicamente, a "causa" do Protocolo, ou seja, refere-se ao aumento das emissões antrópicas do dióxido de carbono, responsável pela aceleração do aquecimento do planeta (o Efeito Estufa, propriamente dito). São fotografias que mostram engarrafamentos e chaminés, a que denominamos Série “Tubos”.

Nessa Série, há a predominância pelo gesto fotográfico que buscou "ilustrar" o principal elemento constitutivo do discurso científico que institucionaliza Kyoto: o dióxido de carbono. Esse gesto fotgráfico se dá pela preferência de cliques onde se vê emissão de fumaça/poluição, como chaminés, escapamento de carros, imagens de trânsito ou engarrafamentos. É curioso notar que muitas dessas imagens trazem equivocos, como as que mostram torres de plantas geradoras de energia nuclear, que não emite $\mathrm{CO}_{2}$ ou qualquer gás estufa (metano, óxido nitroso). As enormes nuvens brancas liberadas são formadas por vapor d'água. Do ponto de vista do Protocolo de Kyoto, uma usina nuclear produz energia "limpa" quando comparada às demais termelétricas a carvão, a óleo e a gás. É possivel que a significação negativa (a relação direta entre energia nuclear e seus efeitos nocivos à saúde humana e ao meio ambiente) desse tipo de torre justifique seu uso para representar o Protocolo de Kyoto, apesar do equívoco científico envolvido.

Um segundo grupo de fotografias remete aos "efeitos" do aquecimento global, como o degelo dos pólos, dos glaciares, da neve permanente de cumes de montanhas, o aumento do nível do mar, o impacto do degelo sobre a vida selvagem nos pólos, o impacto do aquecimento sobre o solo e a água doce ou na distribuição e aparência das florestas e outras formações vegetais, denominada Série "Branca”. Nela, as fotografias que "retratam" Kyoto mostram as regiões polares, em especial, áreas de estudo sobre o degelo, por isso a preferência por imagens em que pedaços imensos de icebergs estão desprendendo-se ou há marcas claras de derretimento como grandes falhas e rachaduras que se mantêm sem se congelar há certo tempo, com o intuito de ilustrar e documentar as modificações sofridas nas calotas polares face ao aquecimento global. 
Outras imagens, ainda, remetem às "soluções", ou seja, às fontes renováveis de energia - eólica, biomassa, solar. Entretanto, parece haver uma opção pelo registro das windfarms (fazendas eólicas) possivelmente pelo efeito estético dos hélices gigantescos, especialmente ao pôr-do-sol, a que denominamos Série “Girassóis”.

Supomos, em todos esses casos, que, porque a imagem fotográfica estava inicialmente acompanhada do texto da notícia (o espaço de exibição e de legitimação da verdade jornalistica), as imagens possam ser diretamente relacionadas a um discurso cientifico (aquele que foi "pauta" do gesto fotográfico que produziu o fotograma) e que, por isso, as imagens das séries sejam "neutras" em termos de intencionalidade de significação e potencial de sentido. O hábito da interpretação da imagem pela lógica linear da escritura impõe a preponderância da “percepção” cientifica (lugar da significação), em detrimento da fruição sensivel (possibilidade do sentido). Ademais, sem um texto explicativo que identifique estas imagens e as relacionem com o discurso ecológico motor do Protocolo de Kyoto, a "decodificação" não passa de um conjunto de associações genéricas com significados como "fumaça”, “escapamento”, "poluição”, “vento”, “energia eólica”, “gelo”, “Antártica”, “Ártico”, “urso polar”.

Em todas as Séries percebe-se que o momento crucial da construção da significação sobre Kyoto se dá no momento de seu uso pelo veículo de informação, que necessariamente determina um vínculo racional entre os elementos presentes na imagem fotográfica e o texto escrito que a acompanha. Esse processo de escolha de texto e escolha de imagens - a edição, enfim, se reflete na maneira como a percepção pública se organiza em relação ao Protocolo de Kyoto.

\section{4 :: O “fora” das Séries - imagens-sensação ::}

Deleuze (2007) desenvolve uma proposta para se pensar a imagem pictórica e a sensação, a qual ele apresenta:

Há duas maneiras de ultrapassar a figuração (quer dizer, tanto o ilustrativo, quanto o narrativo): em direção à forma abstrata, ou em direção à Figura. Cézanne deu a essa via da Figura um nome simples: a sensação. A Figura é a 
forma sensivel referida à sensação: ela age imediatamente sobre o sistema nervoso, que é carne, enquanto a Forma abstrata se dirige ao cérebro e age por intermédio do cérebro, mais próximo do osso. Cézanne certamente não inventou essa via da sensação na pintura, mas deu-lhe u estatuto sem precedentes. A sensação é o contrário do fácil e do lugar-comum, do clichê, mas também do "sensacional", do espontâneo etc. A sensação tem um lado voltado para o sujeito (o sistema nervoso, o movimento vital, o "instinto", o "temperamento", todo um vocabulário comum ao Naturalismo e a Cézanne) e um lado voltado para o objeto ("o fato", o lugar, o acontecimento). Ou melhor, ela não possui lados; ela é as duas coisas indissoluvelmente, é ser-nomundo, como dizem os fenomenólogos: ao mesmo tempo eu me torno na sensação e alguma coisa acontece pela sensação, um pelo outro, um no outro ${ }^{19}$. Em última análise, é o mesmo corpo que dá e recebe sensação, que é tanto objeto quanto sujeito. Eu, como espectador, só experimento a sensação entrando no quadro, tendo acesso à unidade daqueleque sente e do que é sentido. (DELEUZE, 2007, p. 42)

Acreditamos que o grupo de imagens selecionadas e agrupadas como imagens-sensação sejam expressão dessa definição de sensação. Todas elas parecem “desobedecer” às regras técnicas e discursivas que definiriam seu lugar como notícia nas páginas (impressas ou virtuais) de veículos de informação.

As três primeiras imagens fotográficas tentam "se parecer" com a Série Tubos, as duas seguintes, do Urso Polar e dos corpos sobre o glaciar tentam se associar à Série Branca, enquanto as duas últimas imagens poderiam ser juntadas à Série Girassóis. Entretanto, há elementos em cada um desses fotogramas, testemunhos dos gestos fotográficos que os produziram que os "impedem" de se relacionar com as Séries anteriores de maneira fácil e simples. São, definitivamente, imagens fotográficas que fogem ao clichê.

O atrativo em cada uma dessas imagens é a confusão sensivel que elas provocam e não sua capacidade explicativa. Há uma combinação de aspectos da forma e das cores ${ }^{20}$ que interpelam nosso corpo:

\footnotetext{
19 “Henri Maldiney, Regard, parole, espace, Lausanne, L’Âge d'Homme, p.136. Fenomenólogos como Maldiney ou Merleau-Ponty viram em Cézanne o pintor por excelência. Com efeito, eles analisam a sensação, ou melhor, "o sentir", não apenas enquanto relaciona as qualidades sensiveis a um objeto identificável (momento figurativo), mas também à medida que cada qualidade constitui um campo que vale por si mesmo e interfere nos outros (momento "pático"). É esse aspecto da sensação que a fenomenologia de Hegel deixa de lado, e, no entanto, é a base de toda a estética possivel. Cf. Maurice Merleau-Ponty, Fenomenologia da Percepção, Paris, Gallimard. p.240-81; Henri Maldiney, op. cit., p.124-208" Nota da citação.

${ }^{20}$ Até a primeira metade do século XIX, a Académie de Beaux-arts do Institut Français desdenhava o uso de cores vivas e pinceladas "pictóricas" [painterly] (típicos de Delacroix, por exemplo), "por serem tradicionalmente associados à
} 
A lição de Cézanne vai além dos impressionistas: não é no jogo "livre" ou desencarnado da luz e da cor (impressões) que está a Sensação, mas no corpo,mesmo que no corpo de uma maçã. A cor está no corpo, a sensação está no corpo, e não no ar. A sensação é o que é pintado. O que está pintado no quadro é o corpo,não enquanto representado como objeto, mas enquanto vivido como experimentando determinada sensação (o que Lawrence, falando de Cézanne, chamava de "o ser maçanesco da maçã") ${ }^{21}$ (DELEUZE, 2007, p. 42-43).

Poder-se-ia dizer que as imagens selecionadas para compor esse conjunto são mais "complexas" em termos dos elementos visuais (ou dos signos) que remetem a muitos "referentes" ao mesmo tempo, quando, na verdade, a complexidade dessas imagens provém dos seus vetores de força que atualizam a sensação no observador. Ele é, de fato, obrigado a mergulhar nelas, a "perder tempo" em sua circularidade atemporal e se deixar aprisionar, se deixar levar, pela fruição sensivel que elas evocam.

O sistema "dedo-olho-brinquedo" que compõe o gesto fotográfico de cada imagem foi capaz de produzir combinações visuais que escapam da escritura e do texto do Protocolo. Tais fotografias incorporam elementos imagéticos que constroem Figuras sobre Kyoto destacando a Sensação como principal vetor de força estética.

Eis o fio que liga Bacon a Cézanne: pintar a sensação, ou, como diz Bacon, usando palavras muito próximas das de Cézanne, registrar o fato. "É uma questão muito precisa, e difícil saber, por que uma pintura toca diretamente o sistema nervoso $^{22}$. Quando Bacon fala da sensação, ele quer dizer duas coisas muito próximas de Cézanne. Negativamente, ele diz que a forma referida à sensação (Figura) é o contrário da forma referida a um objeto que ela deveria representar (figuração). Segundo a expressão de Valéry, a sensação é o que se transmite diretamente, evitando o desvio ou o tédio de uma história a ser contada $^{23}$. E, positivamente, Bacon não se cansa de dizer que a sensação é o que passa de uma "ordem" à outra, de um "nível" a outro. É por isso que a sensação é mestra deformações, agente de deformações do corpo. E, a esse respeito, pode-se fazer a mesma crítica à pintura figurativa e à pintura abstrata: elas passam pelo cérebro, não agem diretamente sobre o sistema nervoso, não têm acesso à sensação, não produzem a Figura, pois permanecem num mesmo nível. ${ }^{24}$ Elas podem operar transformações da forma, mas não atingem as

\footnotetext{
“emoção" e à "sensibilidade", ambas consideradas "femininas" e destituídas de interesse teórico. Essa visão tinha suas raízes no debate acadêmico, iniciado no século XVII, sobre o valor relativo do dessin (que com freqüência era visto como expressão do controle "masculino") e da cor." (FRASCINA \& BLAKE, 1998, p. 61; itálico nosso)

${ }^{21}$ D. H. Lawrence, Eros et les chien, "Introduction à ces peintures", Paris, Bourgois. (Nota da citação.)

${ }^{22}$ Entrevistas I, p. 44. (Nota da citação.)

${ }^{23}$ Entrevistas I, p. 122-3. (Nota da citação.)

${ }^{24}$ Todos esses temas são constantes nas Entrevistas. (Nota da citação.)
} 
deformações do corpo." (Deleuze, 2007, p. 48-49; itálico do autor; grifo nosso).

Enquanto as imagens das Séries têm um vetor documental maior, ou um vetor de figuração: a referência delas é "o objeto pensado, a coisa figurada". As "imagens-sensação", ao contrário, possuem “o caráter irredutivelmente sintético da sensação” (DELEUZE, 2007, p.49).

O urso assim, não é a figuração de um urso, não parece um urso pela posição “antropomorfizada" que assumiu no momento do clique. Parece simular a despreocupação e o relaxamento típicos dos humanos após um longo dia de trabalho. Onde está a ameaça de que tanto se fala? O urso, tranqüilo, parece desconhecer um destino já traçado.

Os corpos humanos nus deitados sobre o gelo não são "apenas" corpos mas extensões da paisagem. Uma intromissão, uma performance. A nudez da pele humana em contato com a aspereza do gelo frio. A Figura é a reconstrução da paisagem pela sensação, não mais pela "reprodução": um tapete vivo protege o gelo que, muito lentamente, se desfaz. O abraço metafórico que acaricia o planeta onde ele mais "sente dor".

Os hélices na neblina parecem margaridas e não girassóis. A imagem em preto e branco não documenta, evoca uma certa "aura", um recorte único e original, do gesto fotográfico. Outra "margarida" aparece "imponente", sob a neve, antitese do calor do sol. Nas imensas chaminés, as cores, linhas e sombras da fumaça e do vapor d'água em volumes diagonais no céu simula o gesto de pintar a sensação, que registra o fato de maneira a causar deformações no corpo que efetiva o gesto de observação.

"Quando se fala da violência da pintura, isso nada tem a ver com a violência
da guerra." ${ }^{25}$ À violência do representado (o sensacional, o clichê) opõe-se a
violência da sensação, que se identifica com sua ação direta sobre o sistema
nervoso, os níveis pelos quais ela passa e os domínios que atravessa: sendo
Figura, ela não deve nada à natureza de um objeto figurado. É como Artaud: a
crueldade não é aquilo que se pensa e depende cada vez menos daquilo que é
representado. (DELEUZE, 2007, p. 46).

${ }^{25}$ Entrevistas II, p. $29-32$ (e I, p.94-5: ”jamais tentei ser horripilante”) (Nota da citação). 


\section{5 :: O gesto fotográfico sobre Kyoto ::}

Fotografar "a questão ambiental" tem a ver com fotografar a destruição. Há um quê de temática de guerra, uma familiaridade do olhar fotográfico documental sobre a guerra ${ }^{26}$.

O resultado da imagem é uma fotografia de paisagem, mas o gesto que a produziu não buscou a paisagem, mas a guerra declarada dentro dela. É o gesto de busca que acompanha o gesto fotográfico que faz da fotografia sobre meio ambiente menos um fotografar a paisagem, e mais um fotografar a transformação da mesma devido à ação humana ${ }^{27}$. A fotografia sobre meio ambiente só é, assim, uma fotografia "tradicional" sobre paisagem no que tange ao conflito entre racionalidade cientifica e utopia romântica que ela encerra. No que tange ao gesto fotográfico e ao gesto de busca a fotografia sobre meio ambiente possui, assim, uma natureza completamente distinta da fotografia sobre paisagem.

\footnotetext{
${ }^{26}$ A temática ambiental apresenta muitos dos elementos que caracterizam a função documental e de denúncia originada com a fotografia de guerra: "War has been seen as an important subject for photography for a number of reasons: the photographer might reveal scenes and actions which would not otherwise come to the attention of the public; war inevitably throws up scenes of great emotional force which can best be captured by the camera; it has a dark psychic fascination for us, which coexists with our feelings of revulsion." (Price, 2000, p. 74) [“A guerra foi vista como um assunto importante para a fotografia devido a muitas razões: o fotógrafo pode revelar cenas e ações que contrariamente não viriam à atenção do público; a guerra inevitavelmente gera cenas de grande força emotiva que melhor pode ser capturadas pela câmera; a guerra possui uma fascinação psíquica mórbida para nós, que coexiste com nossos sentimentos de repulsa. Tradução Livre.]

${ }^{27}$ A fotografia de guerra e o seu uso como documento, desde a Guerra da Criméia (1853-1856), passando pela Guerra Civil Americana (1861-1865) e pela Guerra Civil Espanhola (1936-1939) forneceu os fundamentos para o desenvolvimento do fotojornalismo (Price, 2000, p. 70). Apesar de sua origem técnica francesa, a fotografia estabeleceu-se como prática anglo-saxônica, desde a febre do daguerreótipo, nos Estados Unidos, até o início do fotojornalismo. Primeiro por iniciativa do jornal londrino "Times", que despachou Roger Fenton para cobrir a Guerra da Criméia a pedido de seu melhor repórter, William Russel, e mais tarde pelo uso da fotografia na Guerra Civil Americana (mais para retratos dos combatentes, do que exatamente para documentar e ilustrar os jornais da época). Contudo, foi o uso intensivo da fotografia como ilustração da Guerra Civil Espanhola que definiu para o público um modo de ver a guerra, especialmente pelas fotografias produzidas por Robert Capa. Do ponto de vista da história da fotografia, é nesse contexto que se considera e se discute o papel dos fotógrafos norte-americanos na criação dos primeiros estilos e temas fotográficos - ação, viagem, paisagem, retrato - que foram emulados em todo mundo, especialmente durante a primeira metade do século 20. É desse período o sucesso das revistas Life e The Life Photographer, além de outras publicações americanas voltadas à fotografia e que "influenciaram", de alguma maneira, os modos de ver e de congelar momentos de fotógrafos asiáticos, europeus, sul-americanos, indianos e chineses até que eles começassem a produzir e espalhar novas formas de olhar que impactassem e radicalizassem o que era considerado "a sensibilidade americana", redefinindo e ampliando o modo de fotografar proveniente da prática jornalística norte-americana, bem como sua missão, suas limitações e seus tabus. Disponível em: http://parsons.edu/departments/course_detail.aspx?dID=80\&sdID=106\&ptype=1\&cID=3354 Acesso em: 15 Jan. 2008.
} 
Fotografar o meio ambiente é retratar essa relação conflituosa que existe entre a brutalidade do "mundo artificial" do Homem e a suposta delicadeza harmônica ou a suposta resistência tenaz do "mundo natural". Esse "par de opostos" procura ser sempre "representado" ou ter sua tensão apresentada nas fotografias que "retratam" essa "guerra" não-declarada, simbólica, entre o Homem e o ambiente natural ${ }^{28}$. Dai a dificuldade em se criar catálogos fotográficos sobre a questão ambiental: "tudo retrata o meio ambiente", uma vez que "meio ambiente" se refere a tudo que seja "não-humano" (incluindo aí o "não-vivo" do reino mineral). Dos hélices do gerador eólico às Cataratas do Iguaçu, das gigantescas manchas de óleo em alto mar, aos golfinhos de Fernando de Noronha, dos animais selvagens em cativeiro à poluição do ar: tudo que remontar à dependência do Homem para com os recursos naturais do planeta é fotografia sobre "meio ambiente”. E desde a publicação de "Nosso Futuro Comum”, a pobreza decorrente dos diferentes níveis econômicos de regiões macro-politicas do globo também entrou no jogo simbólico que constrói representações fotográficas sobre a questão ambiental.

Há uma ambivalência no gesto fotográfico sobre a guerra que parece se repetir no gesto fotográfico sobre o meio ambiente: o mesmo "clima" de denúncia e de "bare witnessing" que tanto marcou as primeiras décadas do trabalho de organizações como o Greenpeace, o Sea Shephard e a PETA.

A certeza de que fotografar ou relatar eventos cotidianos ou tão dramáticos quanto os de uma guerra têm uma relação direta com a "verdade" que permeia todo o ambiente jornalístico ${ }^{29}$. O fotógrafo de guerra é a expressão máxima da contradição freudiana em nós existente: ele alterna dentro de si pulsão de morte e pulsão de vida - as linhas de força mestras que coordenam o seu gesto fotográfico. Clicar como forma de garantir a vida e de evidenciar a morte. Assim, o gesto

\footnotetext{
${ }^{28}$ Dois exemplos marcantes são os fotojornalistas Bruce Hayle e Edward Burtynsky cujos trabalhos, "Desfigured Landscapes" (2000-2002) e "Manufatured Landscapes" (2002-2005), respectivamente, demonstram graus de destruição variados decorrentes do processo de produção comunista em países do leste europeu e na China. As fotografias mostram de um lado plantas abandonadas como se fossem campos de batalha e de outro um exército de trabalhadores em atividades mecanizadas dentro de fábricas gigantescas. Veja o trabalho de Hayle aqui: http://www.luminouslint.com/_sw.php?action=ACT_VEX\&p1=PHOTOGRAPHER_Bruce_Haley_02\&p2=6\&p3=9\&p4=0935183 187342093615859 e o de Burtynsky em http://www.edwardburtynsky.com/ (na coleção “China”)

${ }^{29}$ Harold Evans, jornalista norte-americano, em artigo escrito, em 2003, sobre os riscos que jornalistas, fotógrafos e cameramen correm para relatar os horrores da Guerra do Iraque, expressa suas dúvidas: "Is journalism worth dying for? Is history worth dying for?" Ao que Tim Porter acrescenta: "Indeed, Evans is asking, is truth worth dying for? That is a question each correspondent must ask himself or herself. Most will answer yes, and some of them, despite all precautions, will die in this coming war."
} 
fotográfico sobre a guerra e sobre meio ambiente é, de certa maneira, marcado por essa contradição interna e isso se desdobra exponencialmente na prática do fotojornalista ${ }^{30}$.

A fotografia sobre meio ambiente é eivada por elementos de uma estética romântica na medida em que o registro da tragédia humana depende de uma vivência heróica do fotógrafo que busca o melhor ângulo para documentar a cena do dano e da perda. Assim como o fotojornalista de guerra é herói simplesmente por submeter sua vida ao risco do dano maior, o da própria morte, para poder levar ao mundo "a verdade", o fotógrafo sobre meio ambiente pretende levar à público uma noção ampliada desse risco no registro fotográfico: é a vida em todo planeta que está em jogo e é preciso "medir a distância” em que tanto o fotógrafo, quanto o observador da fotografia estão em relação ao dano, à perda, à morte devido à ameaça de catástrofes ambientais decorrentes, no caso, do efeito estufa.

A fotografia sobre meio ambiente é, analogamente, tal qual a fotografia de guerra, um gesto fotográfico em direção à expressão do dano. Ambas se "alimentam" da necessidade do gesto fotográfico de associar-se ao gesto de busca, aquele que legitima "a verdade" por estar, por sua vez, associado, de alguma maneira, à escritura do discurso científico, à representação heideggeriana: à visão do mundo em que a Ciência é empresa que opera a circulação dos signos "da verdade"e dando a ver o próprio Homem.

Ao tentar compor "narrativas visuais" sobre o Protocolo de Kyoto, tenta-se "traduzir" na imagem fotográfica uma noção de tragédia iminente pela tentativa de se evidenciar na imagem significantes que possam ser identificados, genericamente, como dor, sofrimento e perda ${ }^{31}$. Esse

\footnotetext{
${ }^{30}$ Em Antes da Chuva (Before the rain, 1994), de Milcho Manchevski, o personagem principal, elo da trama, é Aleksandar Kirkov, fotógrafo de guerra, premiado com o Pulitzer e que trabalha para uma agência de fotojornalismo em Londres. A relação de Aleksandar com o tempo parece estruturar-se no registro fotográfico, no tempo maquínico, na lente como extensão do olho. Ser um repórter de guerra é, de uma só vez, uma profissão que evidencia a oposição e a interdependência latente entre pulsão de morte e pulsão de vida. Sua ânsia por imagens chocantes da guerra na Bósnia faz com que um guerrilheiro atire para que ele registre o momento do impacto da bala na cabeça de um prisioneiro. $O$ ato fotográfico funde-se ao ato da morte, literalmente. "Eu tomei partido. Minha câmera matou um homem", escreve ele à Anne, a amante abandonada em Londres. A morte como metáfora da inscrição do tempo congelado pelo processo maquínico, transforma-se em relação causa-efeito imediata, literal: tiro/atirar ("shot"/shoot") e fotografar/filmar ("shoot") ganham significações sinônima: "My camera shot/killed a man." Morrer é sair do contexto do fluxo de tempo.

31 Tanto o tsunami de dezembro de 2004, quanto o furacão Katrina, em agosto de 2005, são exemplos de fenômenos naturais registrados e relatados como catástrofes ambientais, mobilizando redes de comunicação do mundo todo, devido à demonstração da força da Natureza, à condição indefesa das vítimas, ao alto número de
} 
suposto apelo ao sentimento pelo uso de "referências" quase concretas aos elementos “ameaçadores" à vida humana dão a impressão de que percepção dessas imagens é imediata, como se o observador estivesse vivenciando o fato, como se seu olho fosse o olho do fotógrafo, a lente da câmera. Dai a força documental de tais fotos, no mais convencional estilo "o que os olhos vêem, o coração sente”. Mas, como veremos adiante, a percepção da imagem fotográfica como dano, não tem relação com o potencial da imagem como comunicação, acontecimento e sentido.

As imagens comunicam pelas sensações que mobilizam no observador, mas essa "provocação" visual nada tem a ver com o peso social e psicológico do realismo no fotojornalismo. A “compreensão" racionalizada dos elementos ou o conteúdo de uma imagem podem se dar pela "leitura" ou "interpretação" do que nela se inscreve como uma invasão ou imposição do texto, da escritura e da formação discursiva a que ela alude. Mas nem sempre o que nos comove conscientemente num produto cultural é o que nos comunica algo novo. Assim, não é o tema, nem a presença sígnica do dano como "referente", nem o caráter documental de denúncia que dispara o sentido, mas o regime estético que pode operar sensações e superar a violência do escritura para se transformar em violência da sensação.

\footnotetext{
mortos e por se tratar de pontos turísticos internacionais. Pela primeira vez, na história da participação do Brasil no Protocolo de Kyoto, a imprensa brasileira estabeleceu relaçōes diretas entre um fenômeno natural, - a violência de um furacão -, e sua possível causa, - o fenômeno das mudanças climáticas -, devido à aceleração do aquecimento do planeta. Nesses casos, entretanto, o que mobiliza significantes, significações e sentidos é a marca do dano psicológico e econômico, registrado em todas as imagens de ambos os acontecimentos. Apesar de existirem imagens dos fenômenos naturais, - tanto do tsunami invadindo praias e hotéis, como das ruas sob forte chuva e ventos -, o que fica de fato documentado não é o fenômeno, mas o resultado dele, o dano. Este é mais duradouro, e, ao congelamento de tempo de cada imagem, corresponde o esforço da superação do dano, cuja temporalidade é mais estendida. Nesses dois casos, as mídias ressuscitaram, mais diretamente, o dano a cada nova imagem publicada do que a relação do mesmo com o discurso ecológico do Protocolo de Kyoto.
} 
:: Referências bibliográficas ::

DELEUZE, Gilles. Francis Bacon: Lógica da Sensação. Rio de Janeiro: Jorge Zahar, 2007.

FRASCINA, Francis e BLAKE, Nigel. As práticas modernas da arte e da modernidade. In: Modernidade e Modernismo: a pintura francesa no século XIX. São Paulo, Cosac \& Naify, 1998. p. 50-140.

FLUSSER, Vilém. Filosofia da caixa preta. Ensaios para uma futura filosofia da fotografia. São Paulo, HUCITEC, 1985.

GUATTARI, Felix e ROLNIK, Suely. Micropolítica: cartografias do desejo. Petrópolis: Vozes, 1996. 
:: Série Tubos :: 

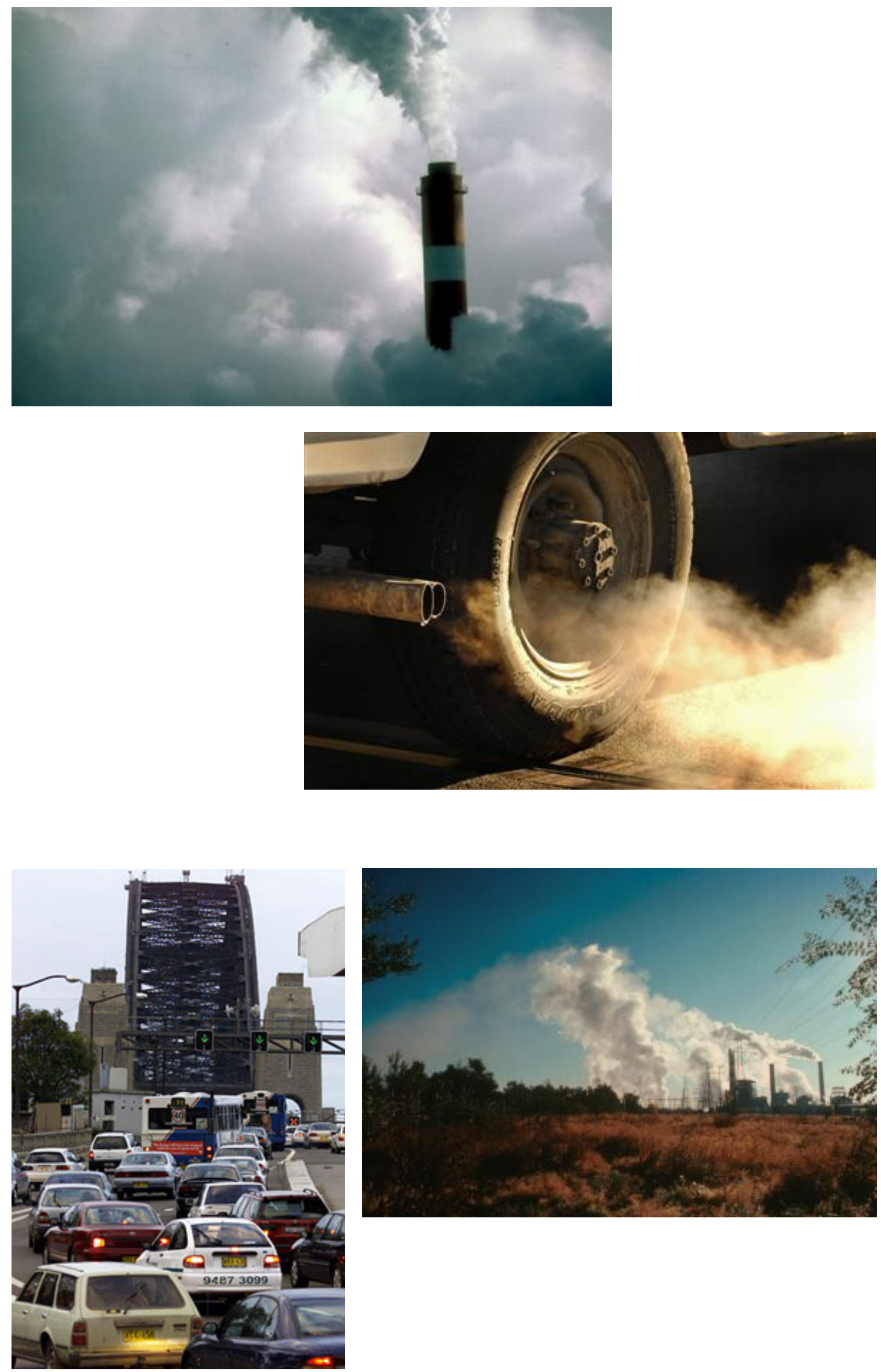


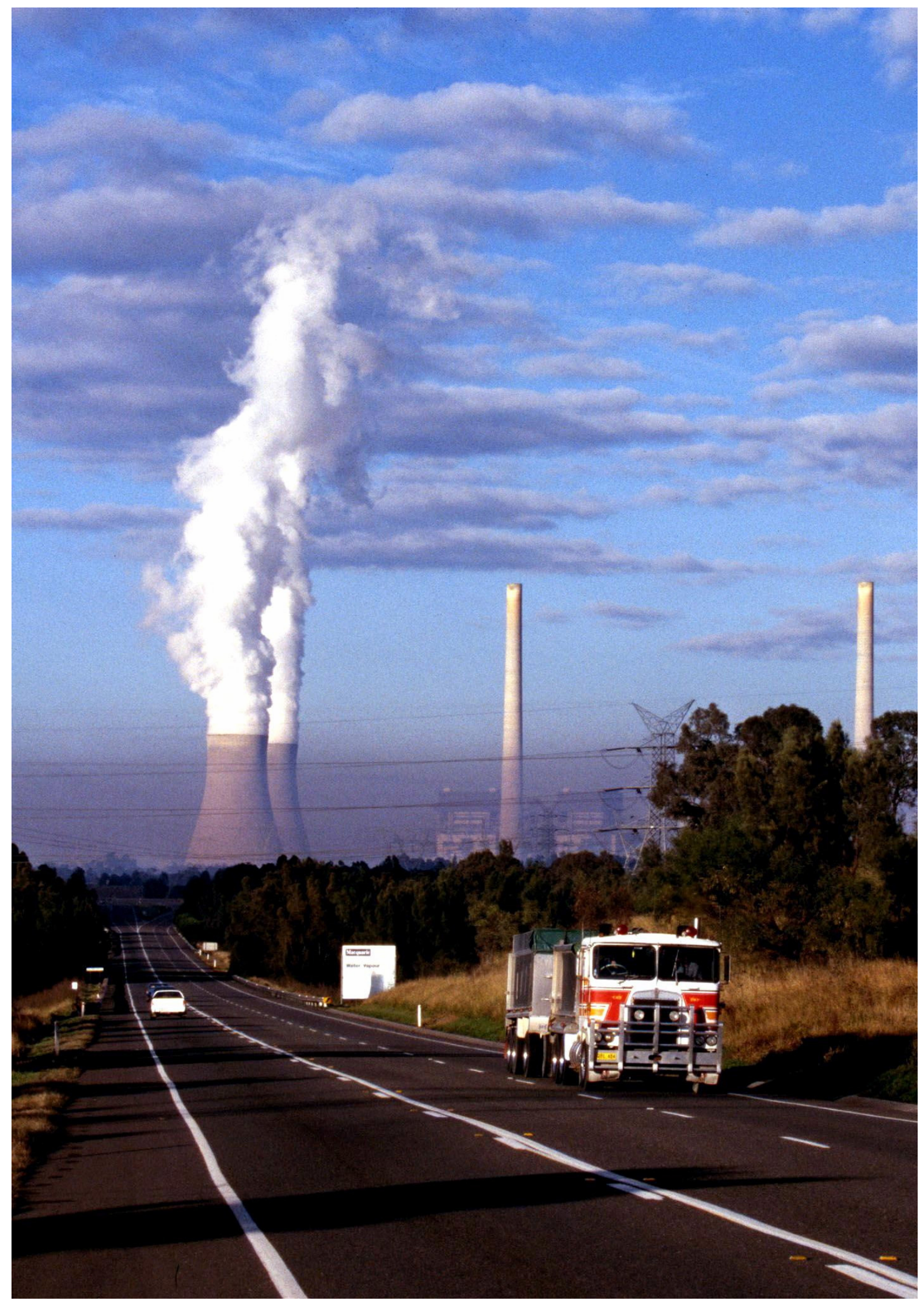



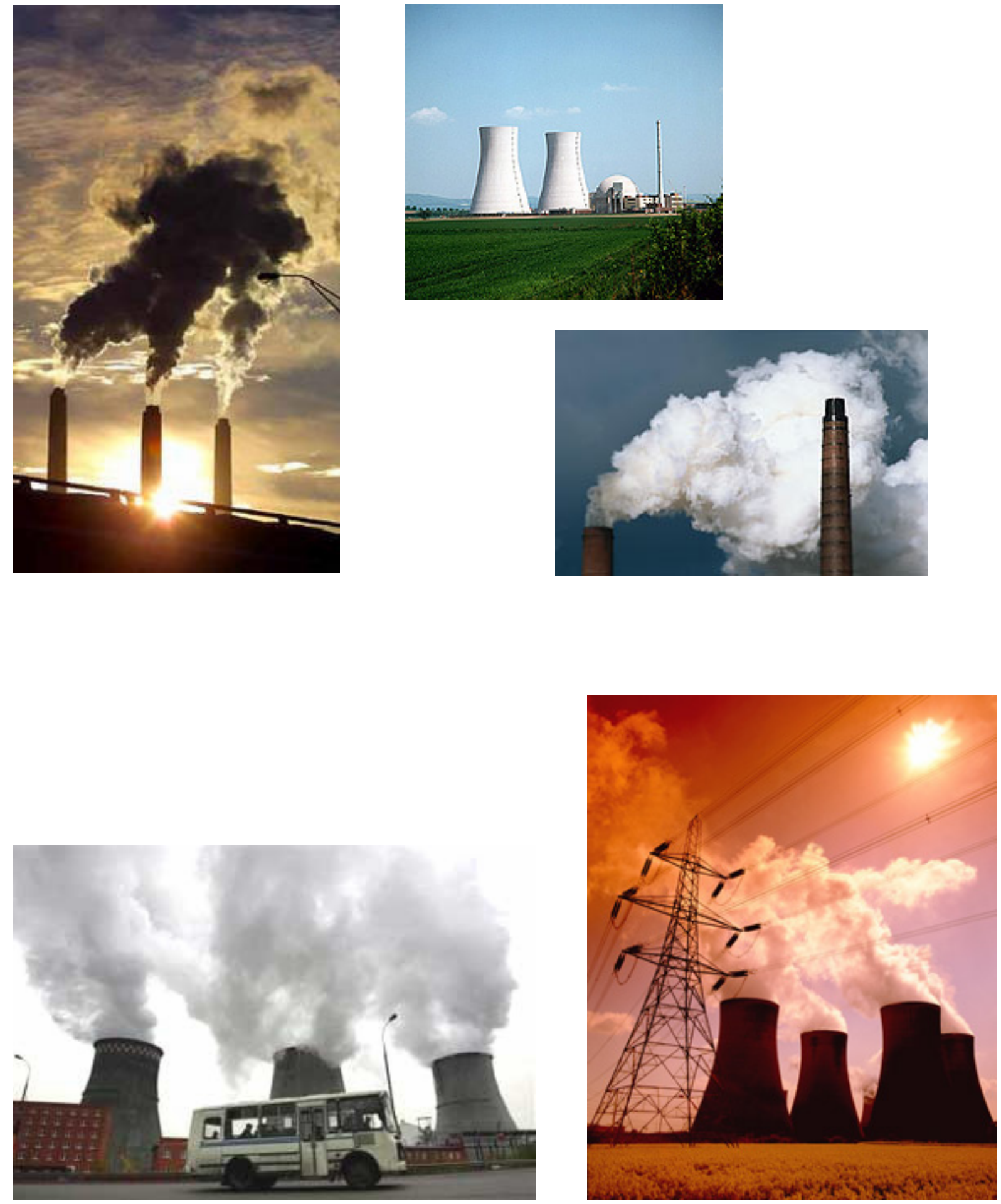
:: Série Branca :: 

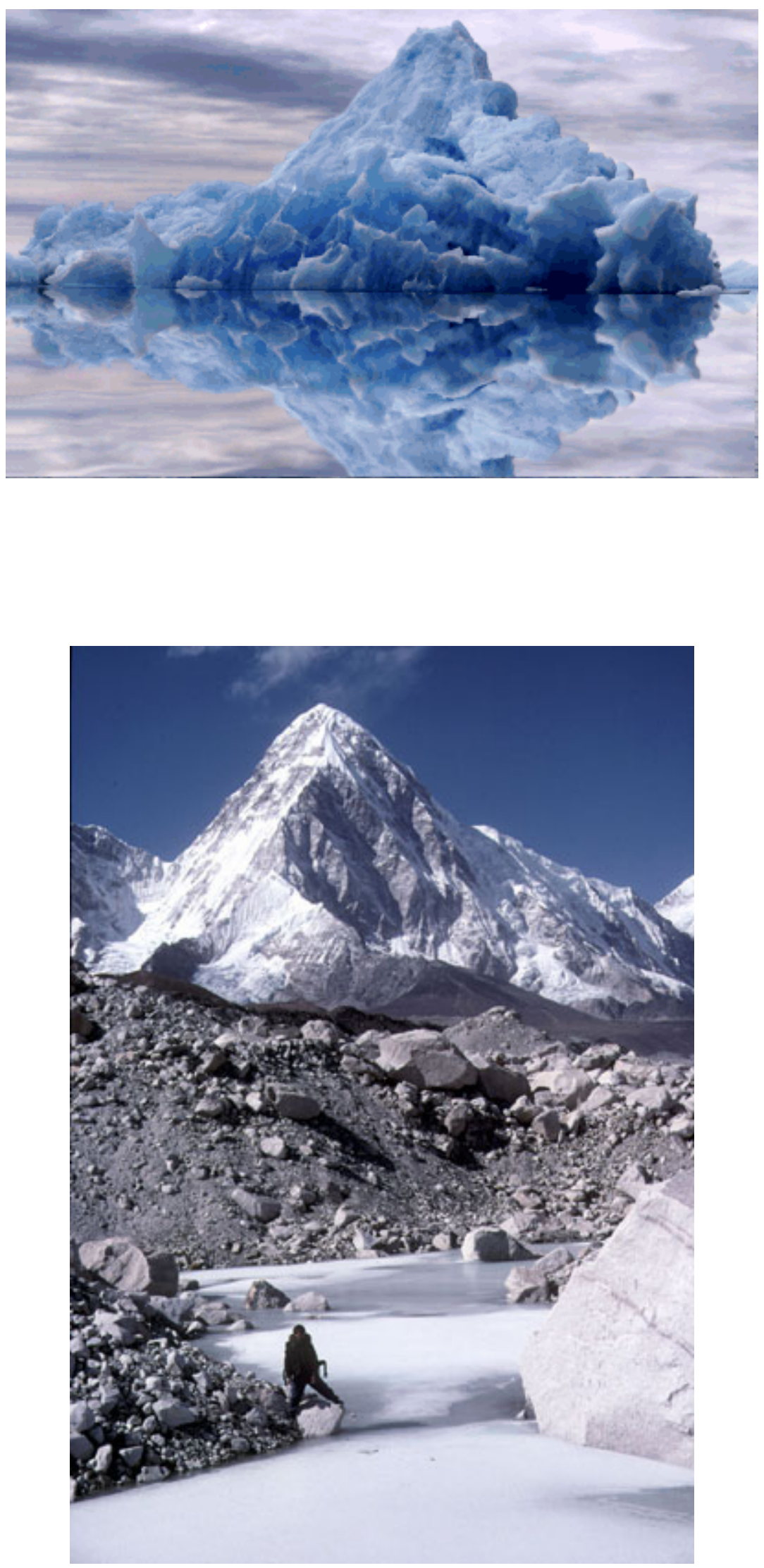

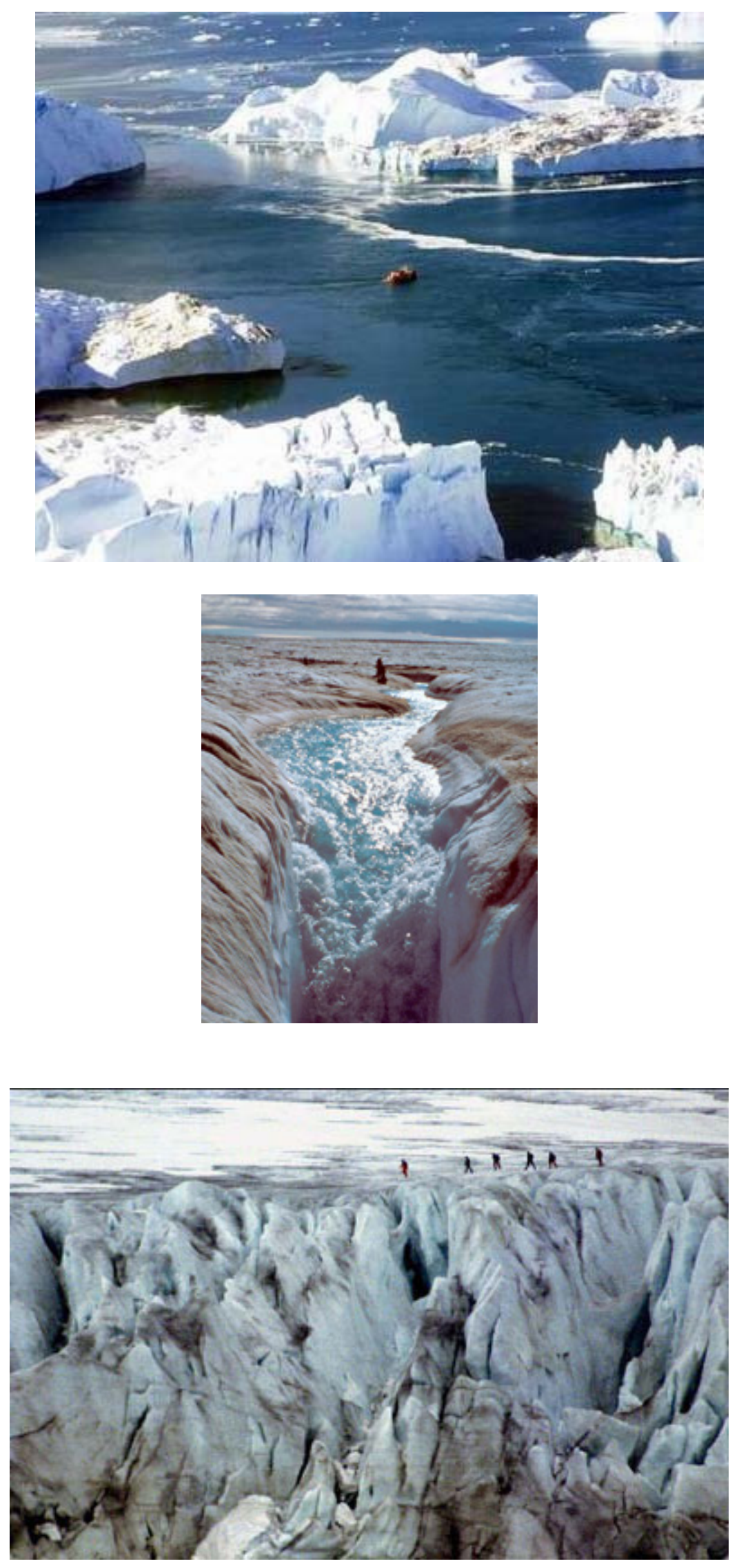

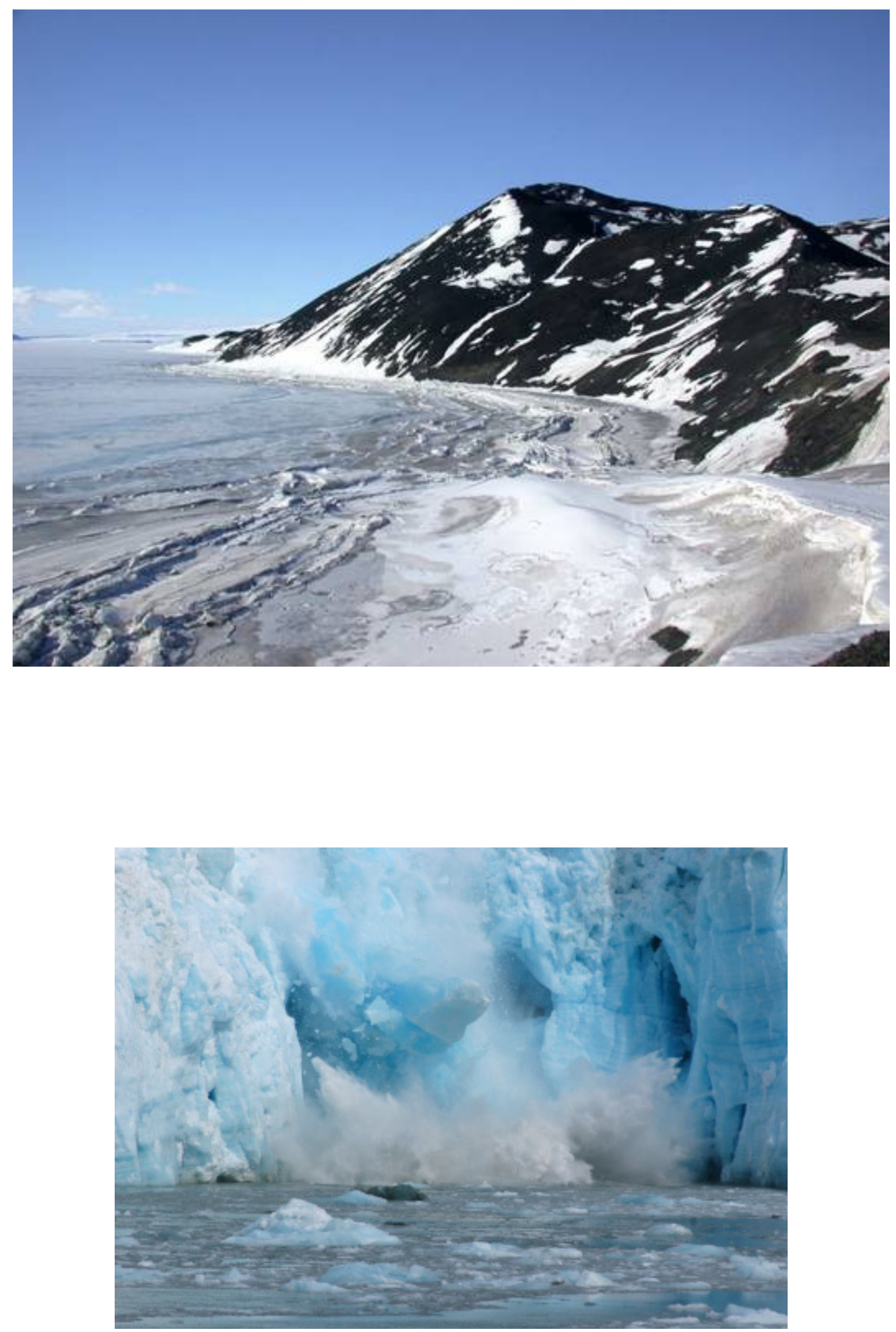

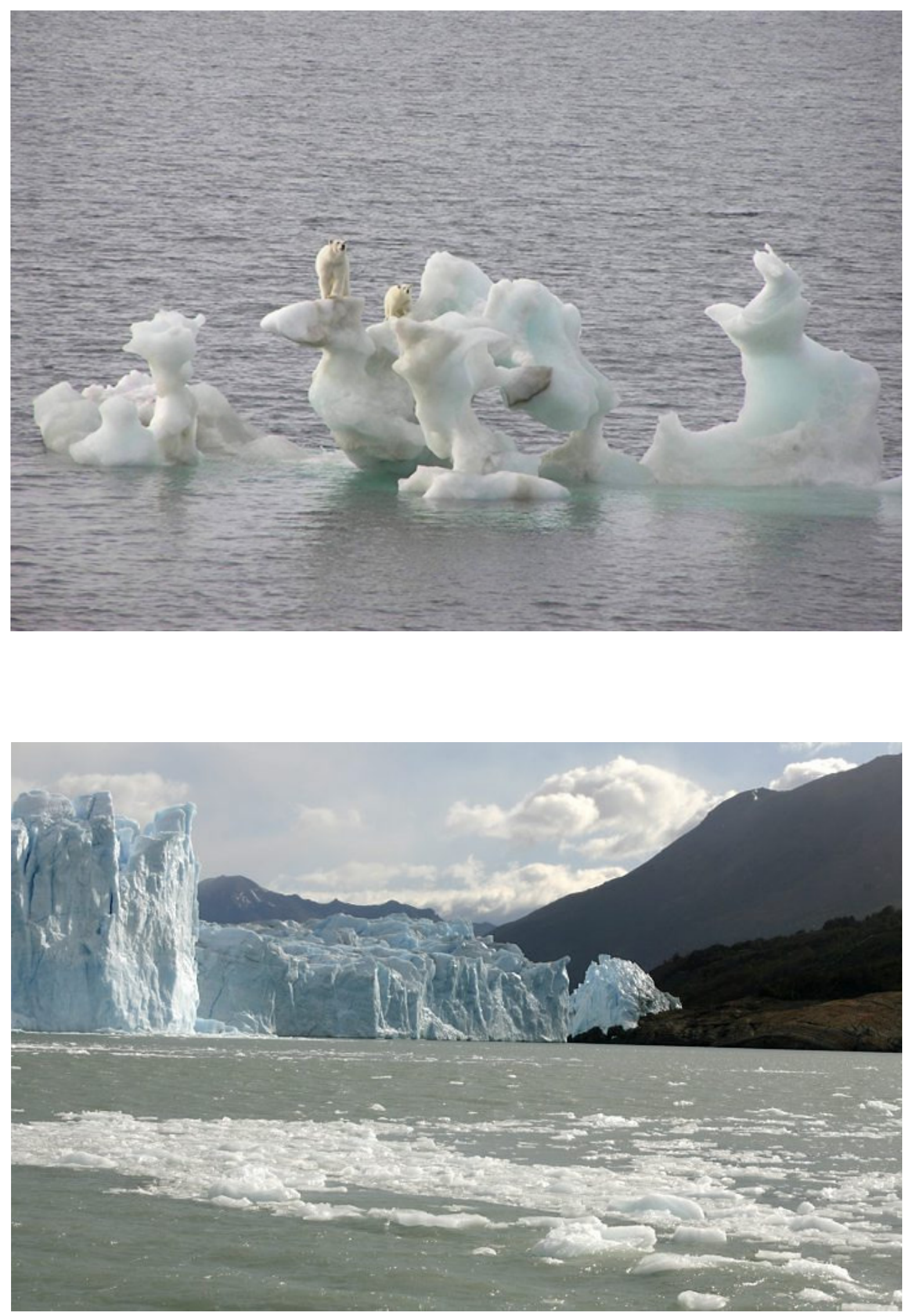
:: Série Girassóis :: 

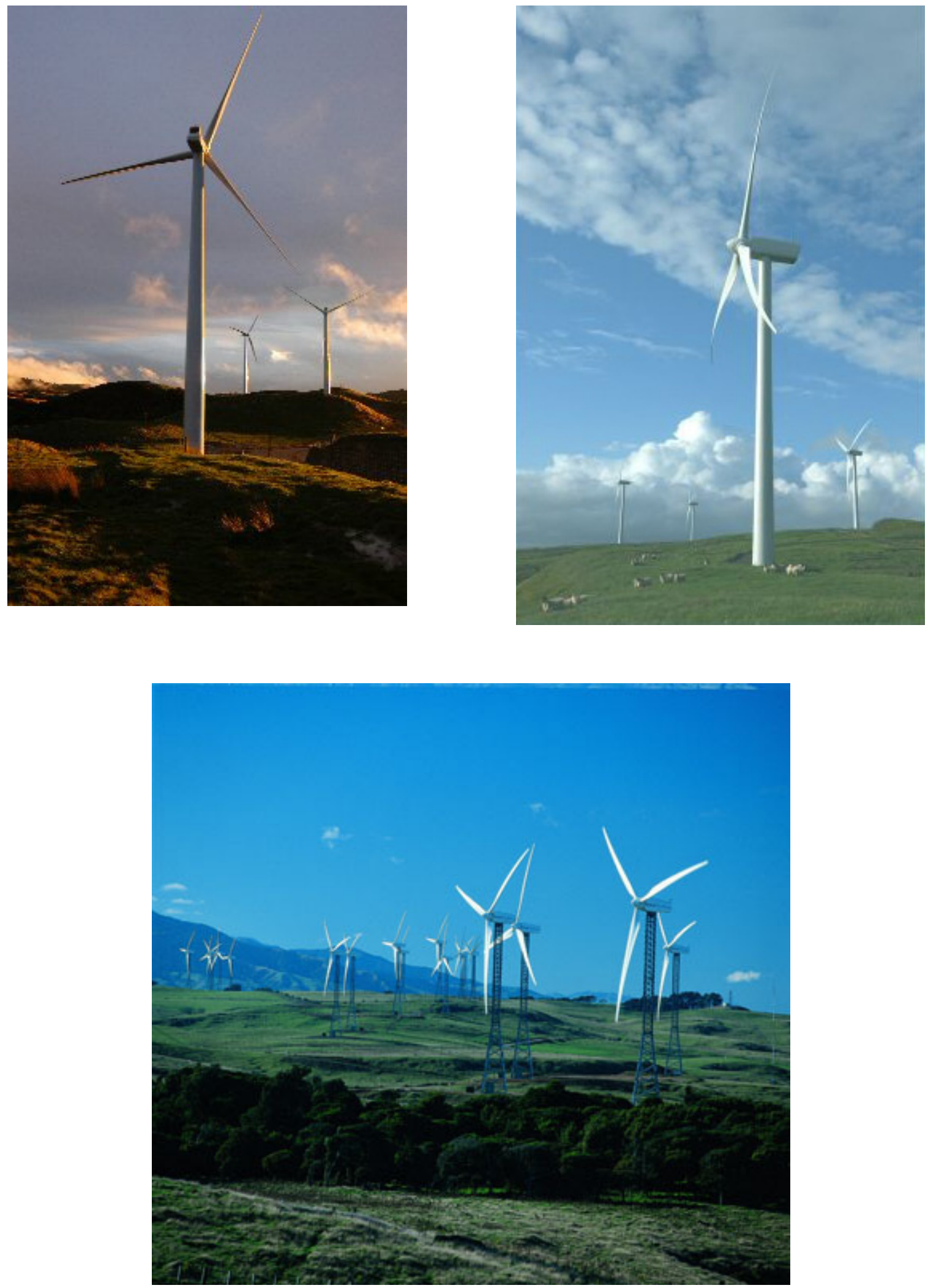

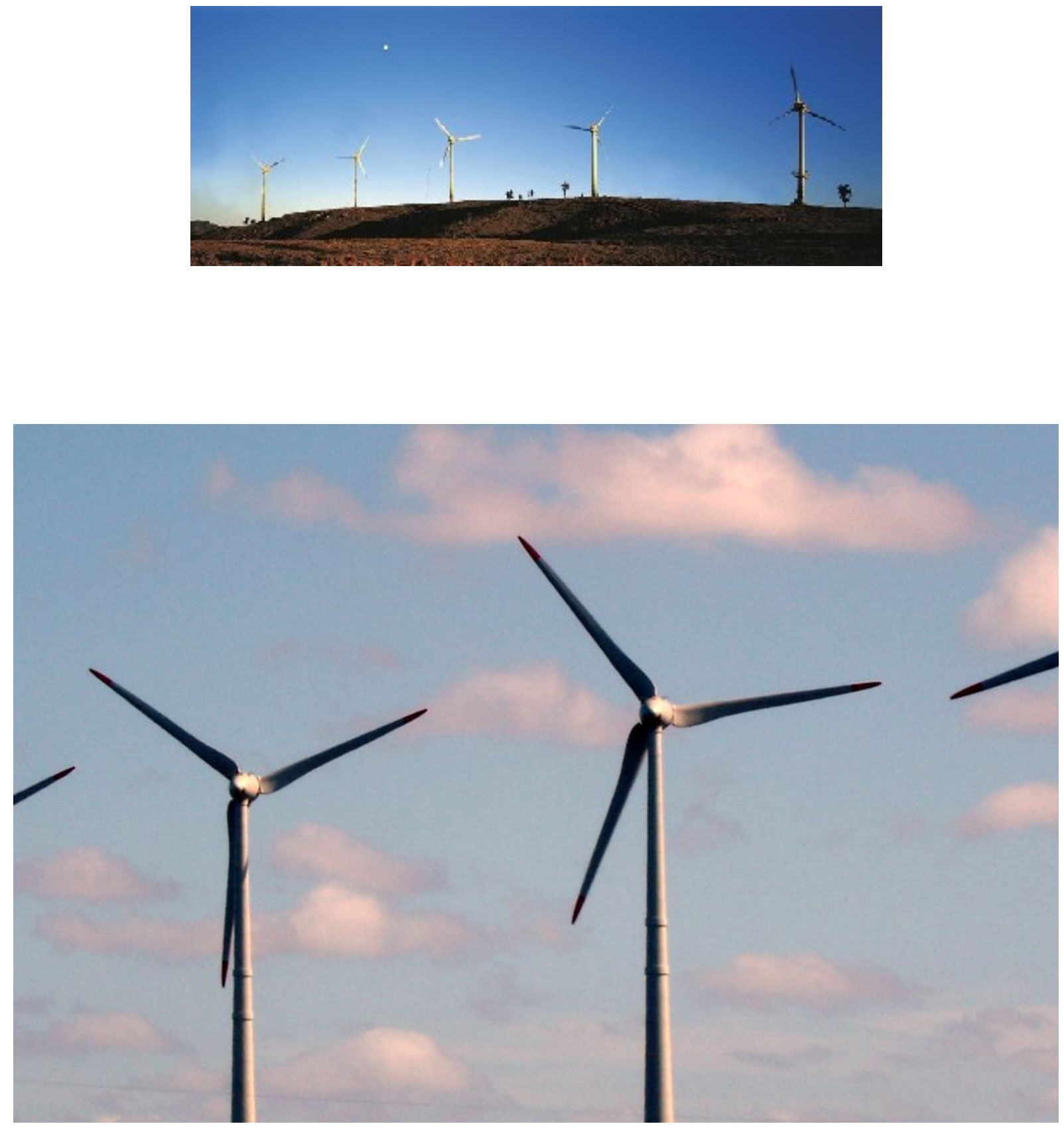

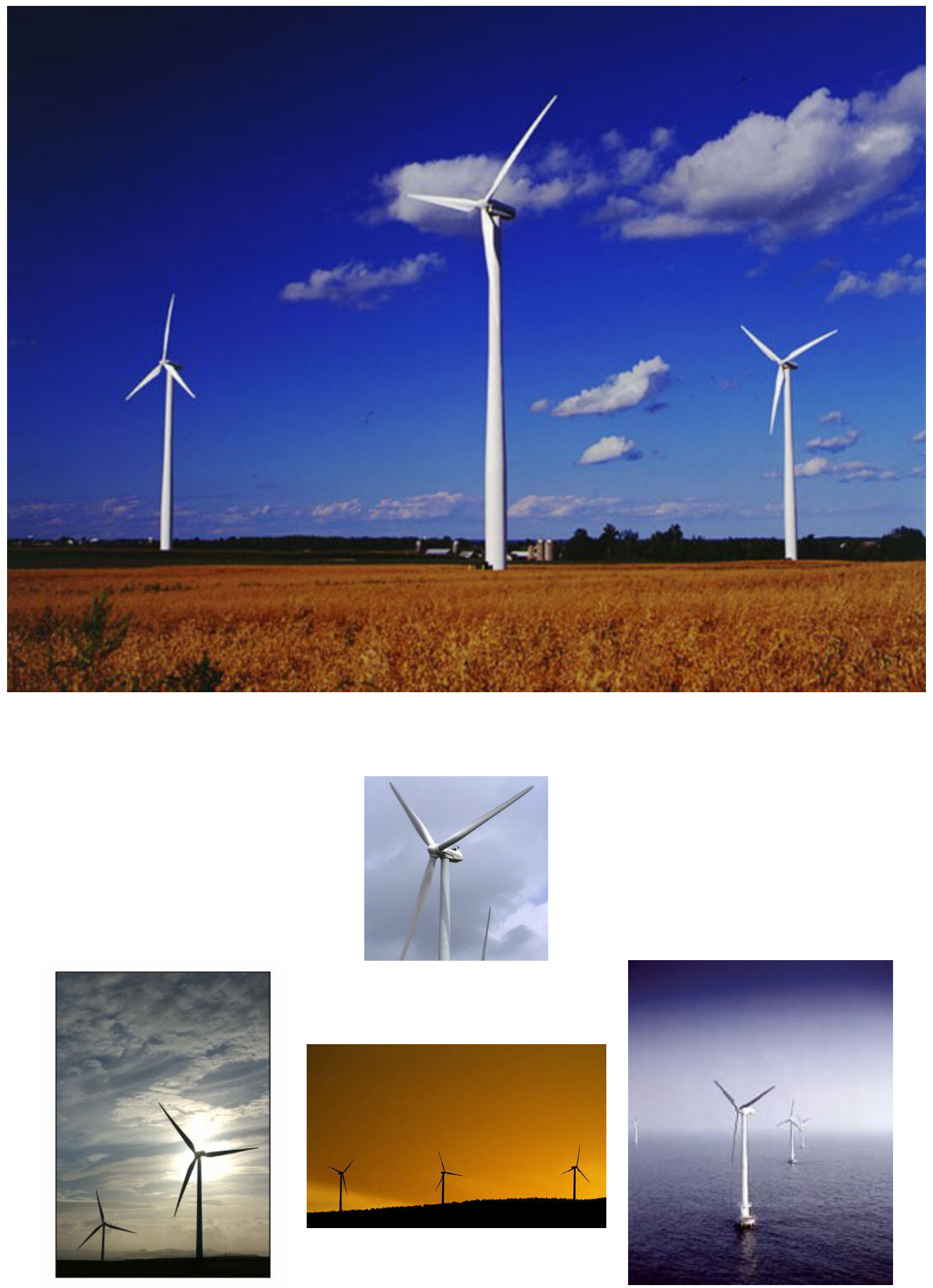


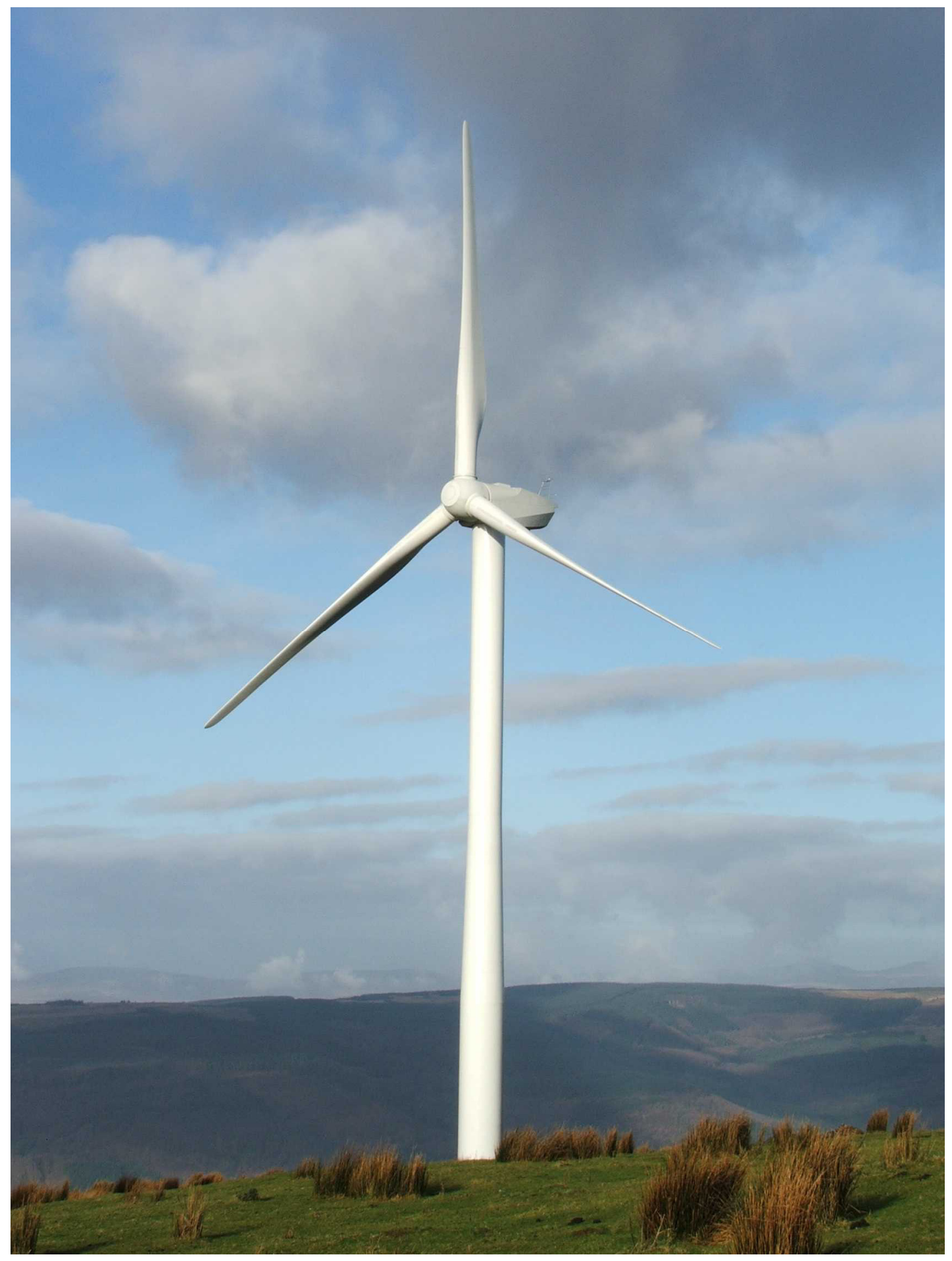


:: Imagens-sensação :: 

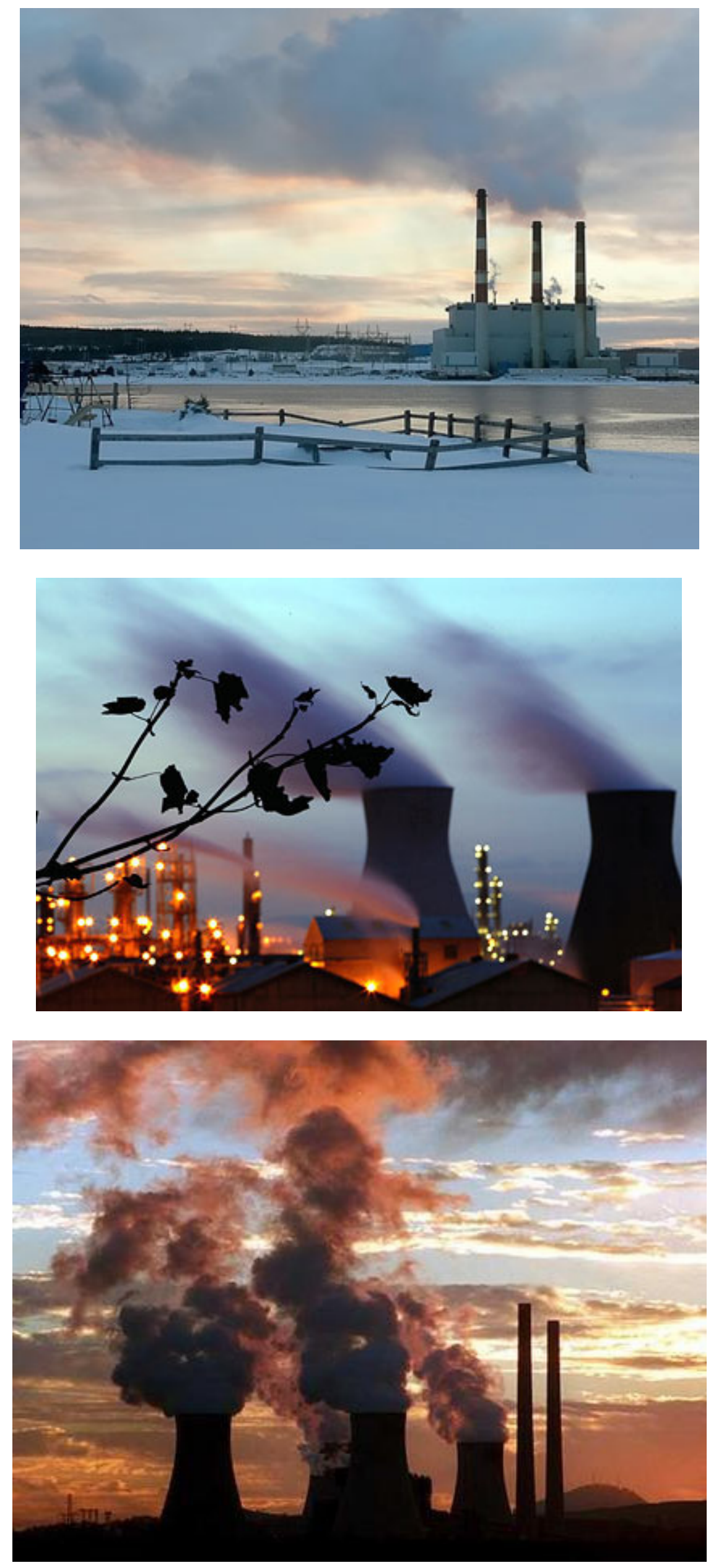

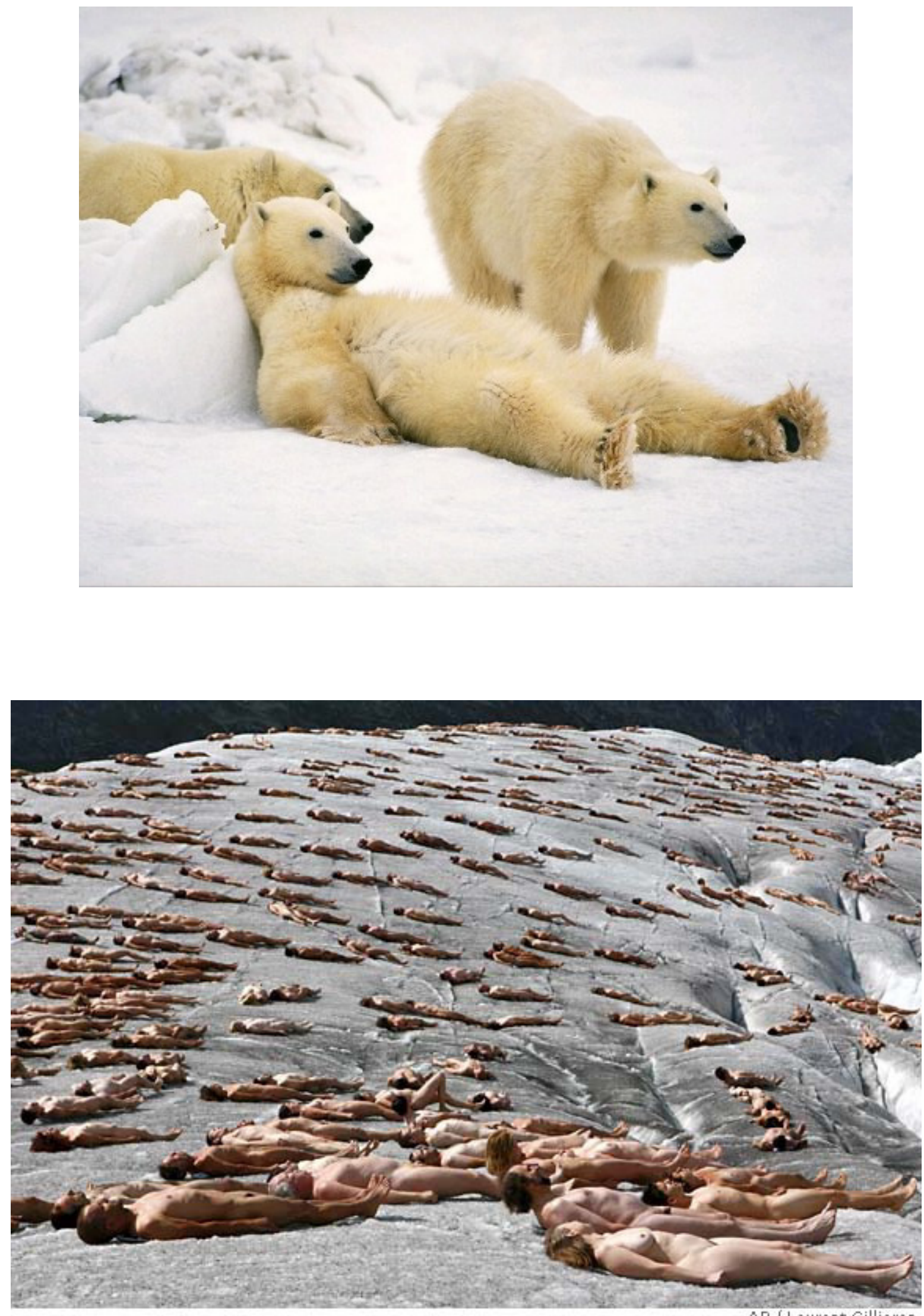



\section{Capítulo 4 :: A representação do Protocolo de Kyoto ::}

:: Representação, biopolitica e escritura ::

“... tanto e mais que os resultados, importa o trabalho da reflexão e talvez seja, sobretudo, isto que um autor pode oferecer, se é que ele pode oferecer alguma coisa”.

Cornelius Castoriadis

\section{:: Representação, biopolítica e escritura ::}

A representação (HEIDEGGER, 1998) sobre o Protocolo de Kyoto existe em vários níveis ou ordens discursivas diferentes. A que abordamos primeiro foi o estabelecimento de uma relação Homem-Natureza, que se inscreve como imagem-magia (FLUSSER, 1998), e como escritura científica (DERRIDA, 2005; 2006). A invenção da imagem como expressão do mítico, vincula o Homem tanto ao sensivel como expressão do estético, quanto à metafísica da presença, tradição do pensamento ocidental.

A escritura do discurso cientifico legitima a construção de uma formação discursiva específica o discurso ecológico, que aos poucos se configura como biopolítica, (FOUCAULT, 2002) e institucionaliza o Protocolo de Kyoto, procedimento disciplinador no nivel macropolítico.

No que tange à relação Homem-Natureza que persistiu como imagem-magia, focamos nossa análise nos aspectos do fotjornalismo sobre o Protocolo de Kyoto, que a partir do gesto fotográfico veicula tanto imagens estereotipadas, reféns do texto que as acompanha, quanto aquelas que, por serem Figura e não figuração, desprendem-se de seus textos e da ordem linear da palavra que lhes impunha significação, apresentando-se como fruição. A essa imagens que apelam para a transformação do corpo daquele que observa chamamos "imagens-sensação". Nesse sentido, o fotojornalismo sobre o Protocolo de Kyoto representa possibilidades de manutenção do vínculo do Homem ao estético e, dessa forma, ao que pode atualizar a Sensação como forma de comunicação extralingüística entre a imagem fotográfica, produto cultural, e o gesto do observador. 
Por outro lado, no que tange à formação discursiva, o regime disciplinar que o Protocolo de Kyoto tenta institucionalizar - a redução das emissões de gás carbônico - potencializa o surgimento de outros niveis discursivos que, indo na direção oposta, institucionalizam o direito de poluir. O complexo Mecanismo de Desenvolvimento Limpo inventou uma "nova moeda", os créditos-de-carbono, que operacionaliza esse direito no nivel macropolitico.

No nivel micropolitico, vetores de forças opostas equilibram e desequilibram as tendências disciplinares que instituem iniciativas como rodizios municipais de automóveis e caminhões, ao mesmo tempo em que há, concomitantemente, o aumento crescente das vendas de automóveis particulares na maioria dos grandes centros urbanos de paises em desenvolvimento.

Assim, os acordos normativos relacionados direta ou indiretamente às complexas questões acerca das fontes de energia para a manutenção do sistema econômico dominante representam mais a escritura juridica e cientifica do que a implementação prática objetivamente disciplinar neles suposta.

Ao mesmo tempo, essa biopolitica global instaura um "cuidar do todo", seja ele o bairro, a floresta ou o planeta. Entretanto, assim como nos ecossistemas, esse embate entre o individual e o todo e sua correlação direta, implica numa nova ética de renúncia que por ser voluntária, tanto no macropolitico quanto no micropolitico, não consegue se estabelecer e se distribuir igualitariamente pelo globo tendo em vista os complexos jogos de interesses econômicos nos dois niveis da ordem discursiva.

O discurso ecológico sobre o Protocolo de Kyoto opera assim como um constante "estado-deatenção" ou "de alerta" em relação ao sistema econômico dominante e às alterações climáticas perceptiveis, que é como se configura, afinal, a idéia de um “cuidar do Todo”. Graças à insistente cobertura dos veículos de informação, esse "simulacro" disciplinar opera consistentemente. O procedimento disciplinatório aparentemente instaurado, existe apenas em potência, tanto no nivel macropolítico quanto no micropolítico.

Essa contradição interna da formação discursiva é evidenciada pela repetição de clichês na escritura científica e no jornalismo que apontam para uma visão de mundo praticamente 
inalterada desde 1987, quando o Protocolo de Kyoto foi criado e mesmo com a sua entrada em vigor em 2005.

A ética ambiental proposta pelo Protocolo de Kyoto é uma ética da renúncia que se contrapõe à lógica de produção e consumo do capitalismo avançado.

O mercado leva o comprador a se transformar, essencialmente, em um caçador de pechinchas: ele não está interessado na origem dos bens ou nas condições sob as quais foram produzidos. Sua única preocupação é conseguir o máximo com seu dinheiro. O mercado, portanto, representa apenas a superfície da sociedade e sua significância relaciona-se com a situação momentânea existente ali e então... é a institucionalização do individualismo e da não-responsabilidade. (SCHUMACHER, 1973, p. 37 apud BRANDÃO, 2004)

Tal ética é reflexo de uma formação discursiva oriunda da economia, e fundada a partir da valoração dos trabalhos cientificos de Nicholas Georgescu-Roegen (1906-1994). Optando por romper com a tradição neo-clássica na economia, Georgescu-Roegen opta por combinar elementos de biologia evolucionária, economia convencional e termodinâmica para estabelecer a nova disciplina, também chamada "bioeconomia".

É totalmente inepto se transportar para toda a espécie humana, ou mesmo para uma nação, as linhas de conduta de um único individuo. É compreensivel que um indivíduo seja impaciente - ou míope - para preferir uma maçã hoje a uma amanhã. $\mathrm{O}$ individuo é mortal. Mas a espécie humana, ou a nação, não têm razões para serem míopes. Precisam agir como se fossem imortais, porque no seu horizonte imediato, eles são. $O$ atual ponto de mutação na evolução da humanidade conclama o indivíduo a compreender que ele é parte de uma corporação quase-imortal e que precisa se livrar desta miopia. (GEORGESCU-ROEGEN, 1976, p. xix. apud BRANDÃO, 2004)․․

Como formação discursiva que expressa a renovação dos princípios da razão instrumental iluminista e depende de uma lógica escritural, o Protocolo de Kyoto supõe, de antemão, que o Homem sempre teve conhecimento extenso acerca dos padrões climáticos, e que por isso, tem as condições materiais - intelectuais e tecnológicas - para controlar o clima a seu favor, isto é, evitando as catástrofes que são previstas. O mercado financeiro e a intensificação das trocas comerciais refletem ordens discursivas que consideram os efeitos negativos ao meio ambeinte como externalidades econômicas. Esses discursos legitimam a "utilização de modelos matemáticos

\footnotetext{
${ }^{1}$ GEORGESCU-ROEGEN, Nicholas. Energy and economic myths: institutional and analytical economic essays. New York: Pergamon, 1976. pp. xxviii-380 apud BRANDÃO, 2004)
} 
de cunho determinista e excessivamente objetivo" que "implicam em deixar de fora o que não se consegue "objetivar" adequadamente, como o capital natural e seus serviços." (BRANDÃO, 2004).

Do is gigantescos sistemas racionalizados, um correspondendo ao humano o outro ao nãohumano se confrontam, pois, discursivamente pelo gesto de busca e pela biopolítica dele derivada: o capitalismo, que garante a vida do Homem, e o clima, que garante a vida no planeta Terra. Metáfora perfeita para a configuração atual da relação Homem-Natureza.

Todos os discursos de verdade, apesar de abstratos, encontram na escritura uma base concreta para sua legitimação, ainda que baseada numa metafísica da presença. A operação discursiva se dá em duas instâncias, portanto: a da organização institucional e a da produção da escritura.

A noção de escritura de Derrida $(2005 ; 2006)$ não deixa escapar nenhum dos conceitos utilizados nesta pesquisa da tradição da metafísica da presença, implicados como estamos em nossa própria escritura.

A representação do discurso ecológico sobre o Protocolo de Kyoto é animada pela (ou reafirma a) metafísica da presença com respeito ao sentido do signo escrito, falado ou fotografado ser um sinal, um traço que está no lugar de uma outra coisa, a qual pode ser um objeto concreto, ou um conceito abstrato. Já que o signo não é uma presença, a coisa ou o conceito não está presente no signo, é um rastro. Mas a natureza do discurso é tal que, quer seja fala, quer seja escritura, não podemos deixar de ter a ilusão de ver o signo como uma presença, isto é, de ver no signo a presença da "coisa" ou do "conceito".

Apenas as imagens-sensação parecem ser menos pressionadas por todos esses elementos metafísicos, característicos do discurso ecológico contemporâneo. A possibilidade de se sofrer afecções a parir da observação daquelas imagens parece permitir uma experiência sensória e estética livre do aprisionamento escritural que o discurso ecológico impõe. Essa experiência estética, no entanto, pode refletir-se como algo totalmente diferente do que o discurso ecológico defende como disciplinatório. 
A necessidade de pensarmos a questão ambiental, a partir de um ponto de vista multidisciplinar focado na cultura, na epistemologia e na filosofia, mostrou que a temática da sustentabilidade, cuja relevância politica, econômica e cultural só faz aumentar, atribui a si mesma uma série de valorações relacionadas à "conscientização" e à transformação de comportamentos por meio do acesso à informação sobre os danos causados à Natureza. Entretanto, a escritura dos conceitos ecológicos fundamentais que permitiu a configuração de uma coesão de idéias que na primeira metade do século XX e organizaram-se como discurso científico e, mais tarde, biopolítico reforça a noção de sujeito do conhecimento da tradição filosófica ocidental, minuciosa e lentamente organizada pela metafísica da presença, uma vez que a filosofia das luzes, é o sustentáculo moderno dessa metafísica.

O logocentrismo que fundamenta a temática da sustentabilidade organiza formações discursivas que parecem contradizer a comunicação entendida como processo e vínculo entre os homens e, mais ainda, a possibilidade de sentido como acontecimento advir de processos comunicativos. Como disse Derrida, "O que foi inventivo em dado contexto sócio-histórico pode não sê-lo mais na contemporaneidade. Melhor seria apelar a outras "ficções teóricas" capazes de nos livrar da ilusão do sujeito, da metafísica da presença, das oposições que impedem a disseminação da diferença pura." ${ }^{2}$

Tal qual o processo de representação pela palavra, quando utilizada para descrever, narrar ou relatar um fato cotidiano, a imagem técnica não é o próprio fato, mas uma versão dele. A suposta neutralidade do foto-repórter é idêntica à suposta neutralidade do jornalista do texto escrito ou falado: um mito tradicional do jornalismo moderno, que se baseia numa transposição do mito da neutralidade cientifica para a prática jornalistica.

Dessa forma, os media interferem no entendimento da questão ambiental e do contexto político e econômico no qual ela se insere. A produção exacerbada de imagens sobre a temática ambiental, mais que intermedeia as relações entre discursos políticos complexos: torna-os ainda mais complexos e pulverizados, aumentando as redes de significação.

\footnotetext{
${ }^{2}$ SAFATLE, Vladimir; CHNAIDERMAN, Miriam; TELLES, Sérgio e KUPERMANN, Daniel Psicanálise: 4+2 maneiras de manter uma herança viva.

Disponivel em: http://www2.uol.com.br/percurso/main/pcs37/37Debate.htm Acesso em 01 Mai 2008.
} 
No tempo da imagem do mundo, a Ciência como empresa empresta à notícia seu valor de verdade e a imagem fotográfica deve corroborar essa experiência. A notícia sobre Kyoto precisa ser ilustrada. O confronto entre os dois sistemas, explicado e esmiuçado. Mas essa vinculação com a palavra produz imagens clichês, incapazes de comunicar.

Por outro lado, essa imersão escritural da fotografia (e de outras imagens técnicas modernas) possui um escape por meio da estética. O discurso estético é um espaço de legitimação, afirmando aquilo que pode ser considerado arte, mas também de apreciação - quer seja do belo, quer seja do bizarro, do inesperado. É o espaço do estético que abre a possibilidade de fruição e de Sensação, e pode, assim, intervir/interferir nos processos de significação impostos pela escritura. É dessa relação conflituosa, entre o valor estético e a escritura que o Sentido pode emergir. 


\section{:: Referências bibliográficas ::}

BRANDÃO, Carlos Eduardo Lessa. Nicholas Georgescu-Roegen, epistemologia e desenvolvimento sustentável. Anais do Seminário "Homenagem ao Professor Nicholas Georgescu-Roegen”. Sociedade Brasileira de Economia Ecológica, Instituto de Economia da Unicamp e Faculdade de Economia e Administração da USP. São Paulo, 2-3 de setembro de 2004. Disponivel em: http://www.ivig.coppe.ufrj.br/doc/suste.pdf Acesso em: 03 Mai. 2008.

DERRIDA, Jacques. Gramatologia. São Paulo: Perspectiva, 2006.

A escritura e a diferença. São Paulo: Perspectiva, 2005.

FLUSSER, Vilém. Ensaio sobre a Fotografia. Para uma filosofia da técnica. Lisboa: Relógio D'Água, 1998.

FOUCAULT, Michel. Arqueologia do Saber. Rio de Janeiro: Forense Universitária, 2005.

Aula de 17 de março de 1976. In: Em defesa da sociedade. São Paulo:

Martins Fontes, 2002.

HEIDEGGER, Martin. O tempo da imagem no mundo. In: Caminhos de Floresta. Lisboa: Fundacão Calouste Gulbenkian,1998. p. 95-138. 
:: Anexo I ::

Versão Integral do Protocolo de Kyoto 

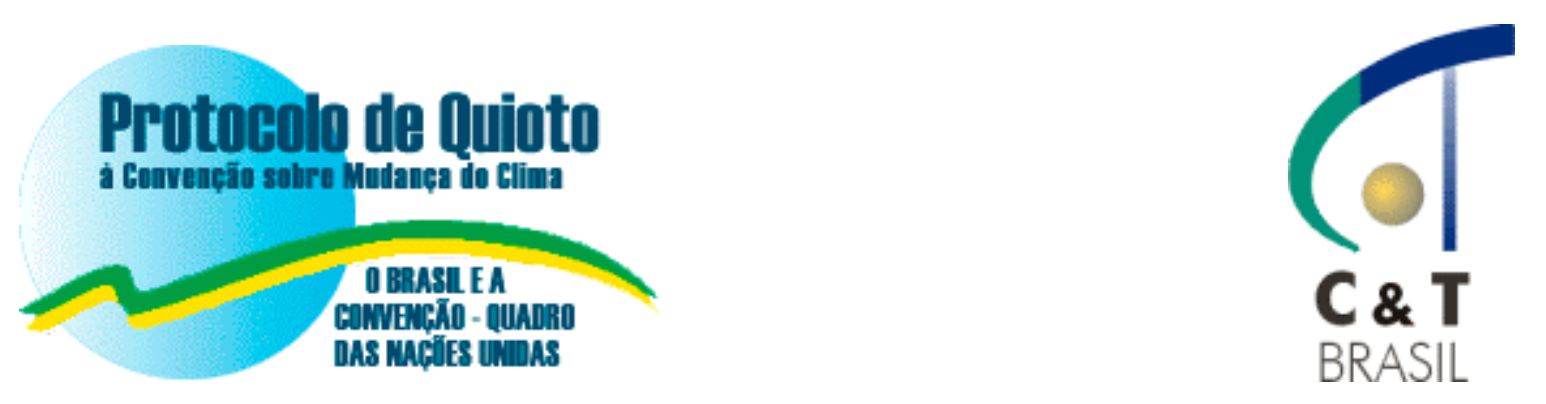

Protocolo de Quioto

Editado e traduzido pelo Ministério da Ciência e Tecnologia com o apoio do Ministério das Relações Exteriores da República Federativa do Brasil 

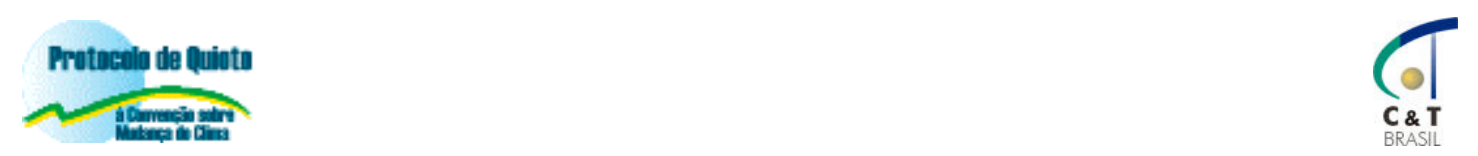

\section{Introdução}

Quando adotaram a Convenção-Quadro das Nações Unidas sobre Mudança do Clima, em 1992, os governos reconheceram que ela poderia ser a propulsora de ações mais enérgicas no futuro. Ao estabelecer um processo permanente de revisão, discussão e troca de informações, a Convenção possibilita a adoção de compromissos adicionais em resposta a mudanças no conhecimento científico e nas disposições políticas.

A primeira revisão da adequação dos compromissos dos países desenvolvidos foi conduzida, como previsto, na primeira sessão da Conferência das Partes (COP-1), que ocorreu em Berlim, em 1995. As Partes decidiram que o compromisso dos países desenvolvidos de voltar suas emissões para os níveis de 1990, até o ano 2000, era inadequado para se atingir o objetivo de longo prazo da Convenção, que consiste em impedir "uma interferência antrópica (produzida pelo homem) perigosa no sistema climático".

Ministros e outras autoridades responderam com a adoção do "Mandato de Berlim" e com o início de um nova fase de discussões sobre o fortalecimento dos compromissos dos países desenvolvidos. O grupo Ad Hoc sobre o Mandato de Berlim (AGBM) foi então formado para elaborar o esboço de um acordo que, após oito sessões, foi encaminhado à COP-3 para negociação final.

Cerca de 10.000 delegados, observadores e jornalistas participaram desse evento de alto nível realizado em Quioto, Japão, em dezembro de 1997. A conferência culminou na decisão por consenso (1/CP.3) de adotar-se um Protocolo segundo o qual os países industrializados reduziriam suas emissões combinadas de gases de efeito estufa em pelo menos $5 \%$ em relação aos níveis de 1990 até o período entre 2008 e 2012. Esse compromisso, com vinculação legal, promete produzir uma reversão da tendência histórica de crescimento das emissões iniciadas nesses países há cerca de 150 anos.

O Protocolo de Quioto foi aberto para assinatura em 16 de março de 1998. Entrará em vigor 90 dias após a sua ratificação por pelo menos 55 Partes da Convenção, incluindo os países desenvolvidos que contabilizaram pelo menos 55\% das emissões totais de dióxido de carbono em 1990 desse grupo de países industrializados. Enquanto isso, as Partes da Convenção sobre Mudança do Clima continuarão a observar os compromissos assumidos sob a Convenção e a preparar-se para a futura implementação do Protocolo.

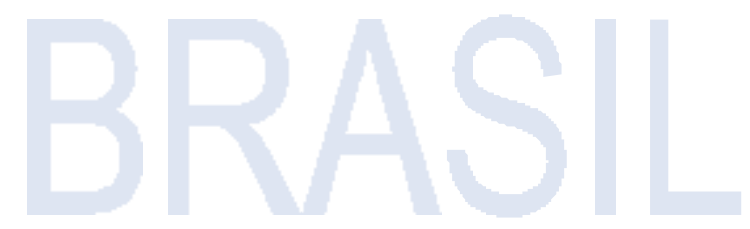



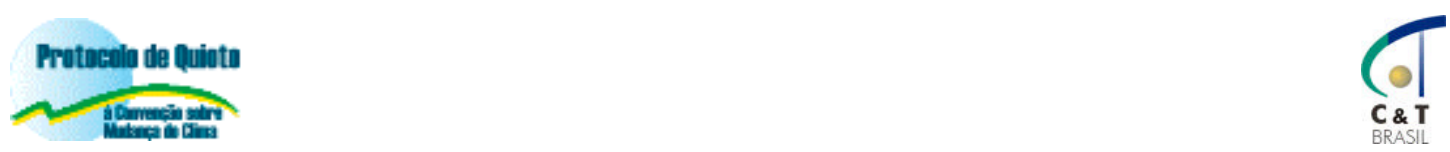

\section{Índice}

Os Artigos do Protocolo de Quioto à Convenção-Quadro das Nações Unidas sobre Mudança do Clima não têm títulos; os tópicos indicativos abaixo visam apenas auxiliar o leitor e não fazem parte do texto oficial, que inicia na pág. 3.

\section{Preâmbulo}

1. Definições

2. Políticas e medidas

3. Compromissos quantificados de limitação e redução de emissões

4. Efetivação de compromissos em conjunto

5. Questões metodológicas

6. Transferência e aquisição de redução de emissões (implementação conjunta)

7. Comunicação de informações

8. Revisão de informações

9. Revisão do Protocolo

10. Continuando a promover a implementação dos compromissos existentes

11. Mecanismo financeiro

12. Mecanismo de desenvolvimento limpo

13. Conferência das Partes na qualidade de reunião das Partes do Protocolo

14. Secretariado

15. Órgãos subsidiários

16. Processo multilateral de consultas

17. Comércio de emissões

18. Não-cumprimento

19. Solução de controvérsias

20. Emendas

21. Adoção e emenda de anexos

22. Direito de voto

23. Depositário

24. Assinatura e ratificação, aceitação, aprovação ou adesão

25. Entrada em vigor

26. Reservas

27. Denúncia

28. Textos autênticos

Anexo A: Gases de efeito estufa e categorias de setores/fontes

Anexo B: Compromissos quantificados de limitação ou redução de emissões por Parte.

A tabela e as três decisões da COP a seguir não fazem parte do Protocolo de Quioto mas foram incluidas porque fornecem informações relevantes para a adoção do Protocolo e sua implementação.

Decisão 1/CP.3: Adoção do Protocolo de Quioto à Convenção-Quadro das Nações Unidas sobre Mudança do Clima

Decisão 2/CP.3: Questões metodológicas relacionadas ao Protocolo de Quioto

Decisão 3/CP.3: Implementação do Artigo 4, parágrafos 8 e 9, da Convenção

Tabela: Total das emissões de dióxido de carbono das Partes do Anexo I em 1990, para os fins do Artigo 25 do Protocolo de Quioto. 

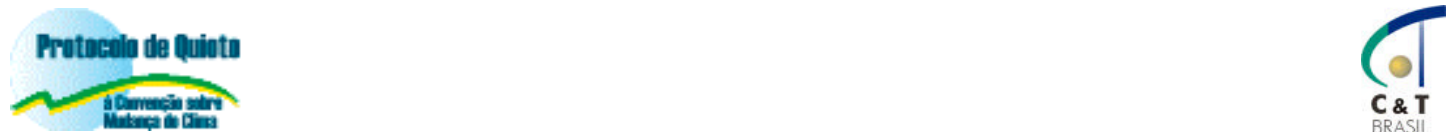

\section{PROTOCOLO DE QUIOTO À CONVENÇÃO-QUADRO DAS NAÇÕES UNIDAS SOBRE MUDANÇA DO CLIMA}

\section{As Partes deste Protocolo,}

Sendo Partes da Convenção-Quadro das Nações Unidas sobre Mudança do Clima, doravante denominada "Convenção",

Procurando atingir o objetivo final da Convenção, conforme expresso no Artigo 2,

Lembrando as disposições da Convenção,

Seguindo as orientações do Artigo 3 da Convenção,

Em conformidade com o Mandato de Berlim adotado pela decisão 1/CP.1 da Conferência das Partes da Convenção em sua primeira sessão,

\section{Convieram no seguinte:}

\section{ARTIGO 1}

Para os fins deste Protocolo, aplicam-se as definições contidas no Artigo 1 da Convenção. Adicionalmente:

1. "Conferência das Partes" significa a Conferência das Partes da Convenção.

"Convenção" significa a Convenção-Quadro das Nações Unidas sobre Mudança do Clima, adotada em Nova York em 9 de maio de 1992.

2. "Painel Intergovernamental sobre Mudança do Clima" significa o Painel Intergovernamental sobre Mudança do Clima estabelecido conjuntamente pela Organização Meteorológica Mundial e pelo Programa das Nações Unidas para o Meio Ambiente em 1988.

3. "Protocolo de Montreal" significa o Protocolo de Montreal sobre Substâncias que Destróem a Camada de Ozônio, adotado em Montreal em 16 de setembro de 1987 e com os ajustes e emendas adotados posteriormente.

4. "Partes presentes e votantes" significa as Partes presentes e que emitam voto afirmativo ou negativo.

5. "Parte" significa uma Parte deste Protocolo, a menos que de outra forma indicado pelo contexto.

6. "Parte incluída no Anexo I" significa uma Parte incluída no Anexo I da Convenção, com as emendas de que possa ser objeto, ou uma Parte que tenha feito uma notificação conforme previsto no Artigo 4, parágrafo 2(g), da Convenção. 

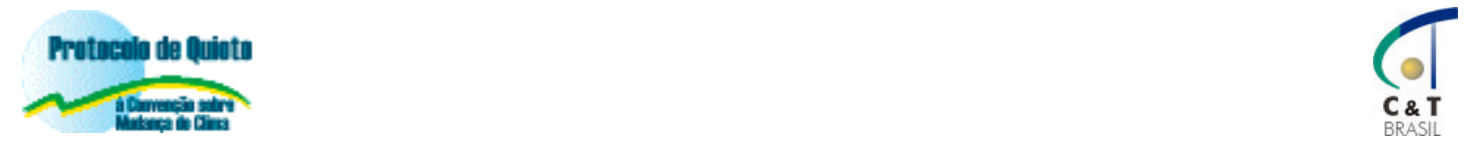

\section{ARTIGO 2}

1. Cada Parte incluída no Anexo I, ao cumprir seus compromissos quantificados de limitação e redução de emissões assumidos sob o Artigo 3, a fim de promover o desenvolvimento sustentável, deve:

(a) Implementar e/ou aprimorar políticas e medidas de acordo com suas circunstâncias nacionais, tais como:

(i) $\mathrm{O}$ aumento da eficiência energética em setores relevantes da economia nacional;

(ii) A proteção e o aumento de sumidouros e reservatórios de gases de efeito estufa não controlados pelo Protocolo de Montreal, levando em conta seus compromissos assumidos em acordos internacionaisrelevantes sobre o meio ambiente, a promoção de práticas sustentáveis de manejo florestal, florestamento e reflorestamento;

(iii) A promoção de formas sustentáveis de agricultura à luz das considerações sobre a mudança do clima;

(iv) A pesquisa, a promoção, o desenvolvimento e o aumento do uso de formas novas e renováveis de energia, de tecnologias de seqüestro de dióxido de carbono e de tecnologias ambientalmente seguras, que sejam avançadas e inovadoras;

(v) A redução gradual ou eliminação de imperfeições de mercado, de incentivos fiscais, de isenções tributárias e tarifárias e de subsídios para todos os setores emissores de gases de efeito estufa que sejam contrários ao objetivo da Convenção e aplicação de instrumentos de mercado;

(vi) O estímulo a reformas adequadas em setores relevantes, visando a promoção de políticas e medidas que limitem ou reduzam emissões de gases de efeito estufa não controlados pelo Protocolo de Montreal;

(vii) Medidas para limitar e/ou reduzir as emissões de gases de efeito estufa não controlados pelo Protocolo de Montreal no setor de transportes;

(viii) A limitação e/ou redução de emissões de metano por meio de sua recuperação e utilização no tratamento de resíduos, bem como na produção, no transporte e na distribuição de energia;

(b) Cooperar com outras Partes incluídas no Anexo I no aumento da eficácia individual e combinada de suas políticas e medidas adotadas segundo este Artigo, conforme o Artigo 4, parágrafo 2(e)(i), da Convenção. Para esse fim, essas Partes devem adotar medidas para compartilhar experiências e trocar informações sobre tais políticas e medidas, inclusive desenvolvendo formas de melhorar sua comparabilidade, transparência e eficácia. A Conferência das Partes na qualidade de reunião das Partes deste Protocolo deve, em sua 

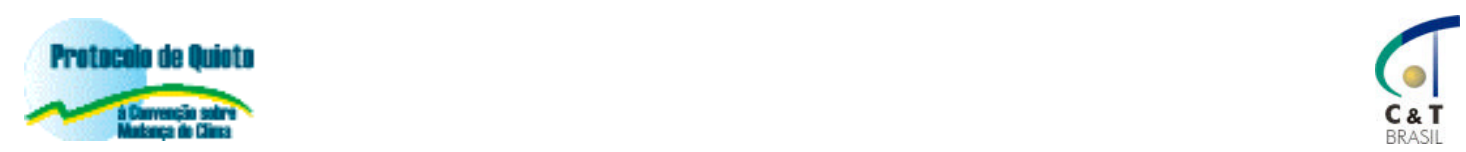

primeira sessão ou tão logo seja praticável a partir de então, considerar maneiras defacilitar tal cooperação, levando em conta toda a informação relevante.

2. As Partes incluídas no Anexo I devem procurar limitar ou reduzir as emissões de gases de efeito estufa não controlados pelo Protocolo de Montreal originárias de combustíveis do transporte aéreo e marítimo internacional, conduzindo o trabalho pela Organização de Aviação Civil Internacional e pela Organização Marítima Internacional, respectivamente.

3. As Partes incluídas no Anexo I devem empenhar-se em implementar políticas e medidas a que se refere este Artigo de forma a minimizar efeitos adversos, incluindo os efeitos adversos da mudança do clima, os efeitos sobre o comércio internacional e os impactos sociais, ambientais e econômicos sobre outras Partes, especialmente as Partes países em desenvolvimento e em particular as identificadas no Artigo 4, parágrafos 8 e 9, da Convenção, levando em conta o Artigo 3 da Convenção. A Conferência das Partes na qualidade de reunião das Partes deste Protocolo pode realizar ações adicionais, conforme o caso, para promover a implementação das disposições deste parágrafo.

4. Caso a Conferência das Partes na qualidade de reunião das Partes deste Protocolo considere proveitoso coordenar qualquer uma das políticas e medidas do parágrafo 1(a) acima, levando em conta as diferentes circunstâncias nacionais e os possíveis efeitos, deve considerar modos e meios de definir a coordenação de tais políticas e medidas.

\section{ARTIGO 3}

1. As Partes incluídas no Anexo I devem, individual ou conjuntamente, assegurar que suas emissões antrópicas agregadas, expressas em dióxido de carbono equivalente, dos gases de efeito estufa listados no Anexo A não excedam suas quantidades atribuídas, calculadas em conformidade com seus compromissos quantificados de limitação e redução de emissões descritos no Anexo B e de acordo com as disposições deste Artigo, com vistas a reduzir suas emissões totais desses gases em pelo menos 5 por cento abaixo dos níveis de 1990 no período de compromisso de 2008 a 2012.

2. Cada Parte incluída no Anexo I deve, até 2005, ter realizado um progresso comprovado para alcançar os compromissos assumidos sob este Protocolo.

3. As variações líquidas nas emissões por fontes e remoções por sumidouros de gases de efeito estufa resultantes de mudança direta, induzida pelo homem, no uso da terra e nas atividades florestais, limitadas ao florestamento, reflorestamento e desflorestamento desde 1990, medidas como variações verificáveis nos estoques de carbono em cada período de compromisso, deverão ser utilizadas para atender os compromissos assumidos sob este Artigo por cada Parte incluída no Anexo I. As emissões por fontes e remoções por sumidouros de gases de efeito estufa associadas a essas atividades devem ser relatadas de maneira transparente e comprovável e revistas em conformidade com os Artigos 7 e 8.

4. Antes da primeira sessão da Conferência das Partes na qualidade de reunião das Partes deste Protocolo, cada Parte incluída no Anexo I deve submeter à consideração do Órgão Subsidiário de Assessoramento Científico e Tecnológico dados para o estabelecimento do seu nível de estoques de carbono em 1990 e possibilitar a estimativa das suas mudanças nos estoques de carbono nos anos subseqüentes. A Conferência das Partes na qualidade de reunião das Partes deste Protocolo deve, em sua primeira sessão ou assim que seja praticável a partir de então, decidir sobre as modalidades, regras e diretrizes sobre como e quais são as atividades adicionais induzidas pelo homem relacionadas com mudanças nas emissões por fontes e remoções por sumidouros de gases de efeito 

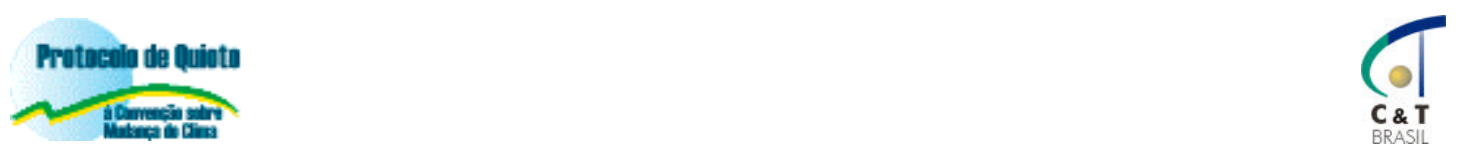

estufa nas categorias de solos agrícolas e de mudança no uso da terra e florestas, que devem ser acrescentadas ou subtraídas da quantidade atribuída para as Partes incluídas no Anexo I, levando em conta as incertezas, a transparência na elaboração de relatório, a comprovação, o trabalho metodológico do Painel Intergovernamental sobre Mudança do Clima, o assessoramento fornecido pelo Órgão Subsidiário de Assessoramento Científico e Tecnológico em conformidade com o Artigo 5 e as decisões da Conferência das Partes. Tal decisão será aplicada a partir do segundo período de compromisso. A Parte poderá optar por aplicar essa decisão sobre as atividades adicionais induzidas pelo homem no seu primeiro período de compromisso, desde que essas atividades tenham se realizado a partir de 1990.

5. As Partes em processo de transição para uma economia de mercado incluídas no Anexo I, cujo ano ou período de base foi estabelecido em conformidade com a decisão 9/CP.2 da Conferência das Partes em sua segunda sessão, devem usar esse ano ou período de base para a implementação dos seus compromissos previstos neste Artigo. Qualquer outra Parte em processo de transição para uma economia de mercado incluída no Anexo I que ainda não tenha submetido a sua primeira comunicação nacional, conforme o Artigo 12 da Convenção, também pode notificar a Conferência das Partes na qualidade de reunião das Partes deste Protocolo da sua intenção de utilizar um ano ou período históricos de base que não 1990 para a implementação de seus compromissos previstos neste Artigo. A Conferência das Partes na qualidade de reunião das Partes deste Protocolo deve decidir sobre a aceitação de tal notificação.

6. Levando em conta o Artigo 4, parágrafo 6, da Convenção, na implementação dos compromissos assumidos sob este Protocolo que não os deste Artigo, a Conferência das Partes na qualidade de reunião das Partes deste Protocolo concederá um certo grau de flexibilidade às Partes em processo de transição para uma economia de mercado incluídas no Anexo I.

7. No primeiro período de compromissos quantificados de limitação e redução de emissões, de 2008 a 2012, a quantidade atribuída para cada Parte incluída no Anexo I deve ser igual à porcentagem descrita no Anexo B de suas emissões antrópicas agregadas, expressas em dióxido de carbono equivalente, dos gases de efeito estufa listados no Anexo A em 1990, ou o ano ou período de base determinado em conformidade com o parágrafo 5 acima, multiplicado por cinco. As Partes incluídas no Anexo I para as quais a mudança no uso da terra e florestas constituíram uma fonte líquida de emissões de gases de efeito estufa em 1990 devem fazer constar, no seu ano ou período de base de emissões de 1990, as emissões antrópicas agregadas por fontes menos as remoções antrópicas por sumidouros em 1990, expressas em dióxido de carbono equivalente, devidas à mudança no uso da terra, com a finalidade de calcular sua quantidade atribuída.

8. Qualquer Parte incluída no Anexo I pode utilizar 1995 como o ano base para os hidrofluorcarbonos, perfluorcarbonos e hexafluoreto de enxofre, na realização dos cálculos mencionados no parágrafo 7 acima.

9. Os compromissos das Partes incluídas no Anexo I para os períodos subseqüentes devem ser estabelecidos em emendas ao Anexo B deste Protocolo, que devem ser adotadas em conformidade com as disposições do Artigo 21, parágrafo 7. A Conferênciadas Partes na qualidade de reunião das Partes deste Protocolo deve dar início à consideração de tais compromissos pelo menos sete anos antes do término do primeiro período de compromisso ao qual se refere o parágrafo 1 acima.

10. Qualquer unidade de redução de emissões, ou qualquer parte de uma quantidade atribuída, que uma Parte adquira de outra Parte em conformidade com as disposições do Artigo 6 ou do Artigo 17 deve ser acrescentada à quantidade atribuída à Parte adquirente. 

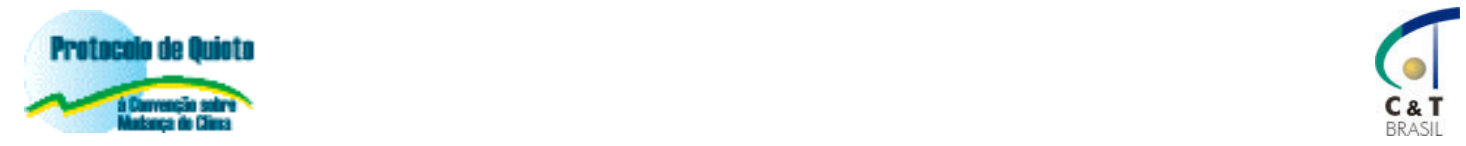

11. Qualquer unidade de redução de emissões, ou qualquer parte de uma quantidade atribuída, que uma Parte transfira para outra Parte em conformidade com as disposições do Artigo 6 ou do Artigo 17 deve ser subtraída da quantidade atribuída à Parte transferidora.

12. Qualquer redução certificada de emissões que uma Parte adquira de outra Parte em conformidade com as disposições do Artigo 12 deve ser acrescentada à quantidade atribuída à Parte adquirente.

13. Se as emissões de uma Parte incluída no Anexo I em um período de compromisso forem inferiores a sua quantidade atribuída prevista neste Artigo, essa diferença, mediante solicitação dessa Parte, deve ser acrescentada à quantidade atribuída a essa Parte para períodos de compromisso subseqüentes.

14. Cada Parte incluída no Anexo I deve empenhar-se para implementar os compromissos mencionados no parágrafo 1 acima de forma que sejam minimizados os efeitos adversos, tanto sociais como ambientais e econômicos, sobre as Partes países em desenvolvimento, particularmente as identificadas no Artigo 4, parágrafos 8 e 9, da Convenção. Em consonância com as decisões pertinentes da Conferência das Partes sobre a implementação desses parágrafos, a Conferência das Partes na qualidade de reunião das Partes deste Protocolo deve, em sua primeira sessão, considerar quais as ações se fazem necessárias para minimizar os efeitos adversos da mudança do clima e/ou os impactos de medidas de resposta sobre as Partes mencionadas nesses parágrafos. Entre as questões a serem consideradas devem estar a obtenção de fundos, seguro e transferência de tecnologia.

\section{ARTIGO 4}

1. Qualquer Parte incluída no Anexo I que tenha acordado em cumprir conjuntamente seus compromissos assumidos sob o Artigo 3 será considerada como tendo cumprido esses compromissos se o total combinado de suas emissões antrópicas agregadas, expressas em dióxido de carbono equivalente, dos gases de efeito estufa listados no Anexo A não exceder suas quantidades atribuídas, calculadas de acordo com seus compromissos quantificados de limitação e redução de emissões, descritos no Anexo $\mathrm{B}$, e em conformidade com as disposições do Artigo 3. $\mathrm{O}$ respectivo nível de emissão determinado para cada uma das Partes do acordo deve ser nele especificado.

2. As Partes de qualquer um desses acordos devem notificar o Secretariado sobre os termos do acordo na data de depósito de seus instrumentos de ratificação, aceitação, aprovação ou adesão a este Protocolo. O Secretariado, por sua vez, deve informar os termos do acordo às Partes e aos signatários da Convenção.

3. Qualquer desses acordos deve permanecer em vigor durante o período de compromisso especificado no Artigo 3, parágrafo 7.

4. Se as Partes atuando conjuntamente assim o fizerem no âmbito de uma organização regional de integração econômica e junto com ela, qualquer alteração na composição da organização após a adoção deste Protocolo não deverá afetar compromissos existentes no âmbito deste Protocolo. Qualquer alteração na composição da organização só será válida para fins dos compromissos previstos no Artigo 3 que sejam adotados em período subseqüente ao dessa alteração. 

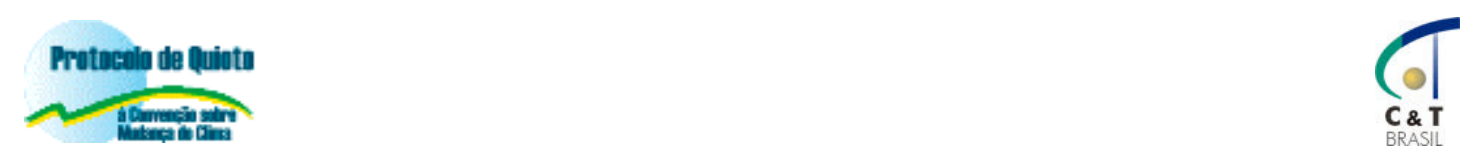

5. Caso as Partes desses acordos não atinjam seu nível total combinado de redução de emissões, cada Parte desses acordos deve se responsabilizar pelo seu próprio nível de emissões determinado no acordo.

6. Se as Partes atuando conjuntamente assim o fizerem no âmbito de uma organização regional de integração econômica que seja Parte deste Protocolo e junto com ela, cada Estado-Membro dessa organização regional de integração econômica individual e conjuntamente com a organização regional de integração econômica, atuando em conformidade com o Artigo 24, no caso de não ser atingido o nível total combinado de redução de emissões, deve se responsabilizar por seu nível de emissões como notificado em conformidade com este Artigo.

\section{ARTIGO 5}

1. Cada Parte incluída no Anexo I deve estabelecer, dentro do período máximo de um ano antes do início do primeiro período de compromisso, um sistema nacional para a estimativa das emissões antrópicas por fontes e das remoções antrópicas por sumidouros de todos os gases de efeito estufa não controlados pelo Protocolo de Montreal. As diretrizes para tais sistemas nacionais, que devem incorporar as metodologias especificadas no parágrafo 2 abaixo, devem ser decididas pela Conferência das Partes na qualidade de reunião das Partes deste Protocolo em sua primeira sessão.

2. As metodologias para a estimativa das emissões antrópicas por fontes e das remoções antrópicas por sumidouros de todos os gases de efeito estufa não controlados pelo Protocolo de Montreal devem ser as aceitas pelo Painel Intergovernamental sobre Mudança do Clima e acordadas pela Conferência das Partes em sua terceira sessão. Onde não forem utilizadas tais metodologias, ajustes adequados devem ser feitos de acordo com as metodologias acordadas pela Conferência das Partes na qualidade de reunião das Partes deste Protocolo em sua primeira sessão. Com base no trabalho, inter alia, do Painel Intergovernamental sobre Mudança do Clima e no assessoramento prestado pelo Órgão Subsidiário de Assessoramento Científico e Tecnológico, a Conferência das Partes na qualidade de reunião das Partes deste Protocolo deve rever periodicamente e, conforme o caso, revisar tais metodologias e ajustes, levando plenamente em conta qualquer decisão pertinente da Conferência das Partes. Qualquer revisão das metodologias ou ajustes deve ser utilizada somente com o propósito de garantir o cumprimento dos compromissos previstos no Artigo 3 com relação a qualquer período de compromisso adotado posteriormente a essa revisão.

3. Os potenciais de aquecimento global utilizados para calcular a equivalência em dióxido de carbono das emissões antrópicas por fontes e das remoções antrópicas por sumidouros dos gases de efeito estufa listados no Anexo A devem ser os aceitos pelo Painel Intergovernamental sobre Mudança do Clima e acordados pela Conferência das Partes em sua terceira sessão. Com base no trabalho, inter alia, do Painel Intergovernamental sobre Mudança do Clima e no assessoramento prestado pelo Órgão Subsidiário de Assessoramento Científico e Tecnológico, a Conferência das Partes na qualidade de reunião das Partes deste Protocolo deve rever periodicamente e, conforme o caso, revisar o potencial de aquecimento global de cada um dos gases de efeito estufa, levandoplenamente em conta qualquer decisão pertinente da Conferência das Partes. Qualquer revisão de um potencial de aquecimento global deve ser aplicada somente aos compromissos assumidos sob o Artigo 3 com relação a qualquer período de compromisso adotado posteriormente a essa revisão. 

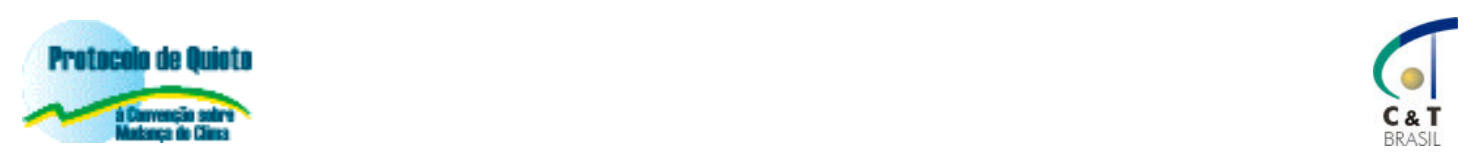

\section{ARTIGO 6}

1. A fim de cumprir os compromissos assumidos sob o Artigo 3, qualquer Parte incluída no Anexo I pode transferir para ou adquirir de qualquer outra dessas Partes unidades de redução de emissões resultantes de projetos visando a redução das emissões antrópicas por fontes ou o aumento das remoções antrópicas por sumidouros de gases de efeito estufa em qualquer setor da economia, desde que:

(a) O projeto tenha a aprovação das Partes envolvidas;

(b) O projeto promova uma redução das emissões por fontes ou um aumento das remoções por sumidouros que sejam adicionais aos que ocorreriam na sua ausência;

(c) A Parte não adquira nenhuma unidade de redução de emissões se não estiver em conformidade com suas obrigações assumidas sob os Artigos 5 e 7; e

(d) A aquisição de unidades de redução de emissões seja suplementar às ações domésticas realizadas com o fim de cumprir os compromissos previstos no Artigo 3.

2. A Conferência das Partes na qualidade de reunião das Partes deste Protocolo pode, em sua primeira sessão ou assim que seja viável a partir de então, aprimorar diretrizes para a implementação deste Artigo, incluindo para verificação e elaboração de relatórios.

3. Uma Parte incluída no Anexo I pode autorizar entidades jurídicas a participarem, sob sua responsabilidade, de ações que promovam a geração, a transferência ou a aquisição, sob este Artigo, de unidades de redução de emissões.

4. Se uma questão de implementação por uma Parte incluída no Anexo I das exigênciasmencionadas neste parágrafo é identificada de acordo com as disposições pertinentes do Artigo 8, as transferências e aquisições de unidades de redução de emissões podem continuar a ser feitas depois de ter sido identificada a questão, desde que quaisquer dessas unidades não sejam usadas pela Parte para atender os seus compromissos assumidos sob o Artigo 3 até que seja resolvida qualquer questão de cumprimento.

\section{ARTIGO 7}

1. Cada Parte incluída no Anexo I deve incorporar ao seu inventário anual de emissões antrópicas por fontes e remoções antrópicas por sumidouros de gases de efeito estufa não controlados pelo Protocolo de Montreal, submetido de acordo com as decisões pertinentes da Conferência das Partes, as informações suplementares necessárias com o propósito de assegurar o cumprimento do Artigo 3, a serem determinadas em conformidade com o parágrafo 4 abaixo.

2. Cada Parte incluída no Anexo I deve incorporar à sua comunicação nacional, submetida de acordo com o Artigo 12 da Convenção, as informações suplementares necessárias para demonstrar o cumprimento dos compromissos assumidos sob este Protocolo, a serem determinadas em conformidade com o parágrafo 4 abaixo.

3. Cada Parte incluída no Anexo I deve submeter as informações solicitadas no parágrafo 1 acima anualmente, começando com o primeiro inventário que deve ser entregue, segundo a Convenção, no primeiro ano do período de compromisso após a entrada em vigor deste Protocolo para essa Parte. 

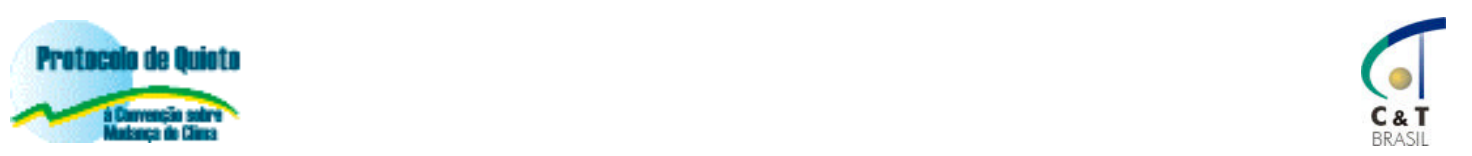

Cada uma dessas Partes deve submeter as informações solicitadas no parágrafo 2 acima como parte da primeira comunicação nacional que deve ser entregue, segundo a Convenção, após a entrada em vigor deste Protocolo para a Parte e após a adoção de diretrizes como previsto no parágrafo 4 abaixo. A freqüência das submissões subseqüentes das informações solicitadas sob este Artigo deve ser determinada pela Conferência das Partes na qualidade de reunião das Partes deste Protocolo, levando em conta qualquer prazo para a submissão de comunicações nacionais conforme decidido pela Conferência das Partes.

4. A Conferência das Partes na qualidade de reunião das Partes deste Protocolo deve adotar em sua primeira sessão, e rever periodicamente a partir de então, diretrizes para apreparação das informações solicitadas sob este Artigo, levando em conta as diretrizes para a preparação de comunicações nacionais das Partes incluídas no Anexo I, adotadas pela Conferência das Partes. A Conferência das Partes na qualidade de reunião das Partes deste Protocolo deve também, antes do primeiro período de compromisso, decidir sobre as modalidades de contabilização das quantidades atribuídas.

\section{ARTIGO 8}

1. As informações submetidas de acordo com o Artigo 7 por cada Parte incluída no Anexo I devem ser revistas por equipes revisoras de especialistas em conformidade com as decisões pertinentes da Conferência das Partes e em consonância com as diretrizes adotadas com esse propósito pela Conferência das Partes na qualidade de reunião das Partes deste Protocolo, conforme o parágrafo 4 abaixo. As informações submetidas segundo o Artigo 7, parágrafo 1, por cada Parte incluída no Anexo I devem ser revistas como parte da compilação anual e contabilização dos inventários de emissões e das quantidades atribuídas. Adicionalmente, as informações submetidas de acordo com o Artigo 7, parágrafo 2, por cada Parte incluída no Anexo I devem ser revistas como parte da revisão das comunicações.

2. As equipes revisoras de especialistas devem ser coordenadas pelo Secretariado e compostas por especialistas selecionados a partir de indicações das Partes da Convenção e, conforme o caso, de organizações intergovernamentais, em conformidade com a orientação dada para esse fim pela Conferência das Partes.

3. O processo de revisão deve produzir uma avaliação técnica completa e abrangente de todos os aspectos da implementação deste Protocolo por uma Parte. As equipes revisoras de especialistas devem preparar um relatório para a Conferência das Partes na qualidade de reunião das Partes deste Protocolo, avaliando a implementação dos compromissos da Parte e identificando possíveis problemas e fatores que possam estar influenciando a efetivação dos compromissos. Esses relatórios devem ser distribuídos pelo Secretariado a todas as Partes da Convenção. O Secretariado deve listar as questões de implementação indicadas em tais relatórios para posterior consideração pela Conferência das Partes na qualidade de reunião das Partes deste Protocolo.

4. A Conferência das Partes na qualidade de reunião das Partes deste Protocolo deve adotar em sua primeira sessão, e rever periodicamente a partir de então, as diretrizes para arevisão da implementação deste Protocolo por equipes revisoras de especialistas, levando em conta as decisões pertinentes da Conferência das Partes. 

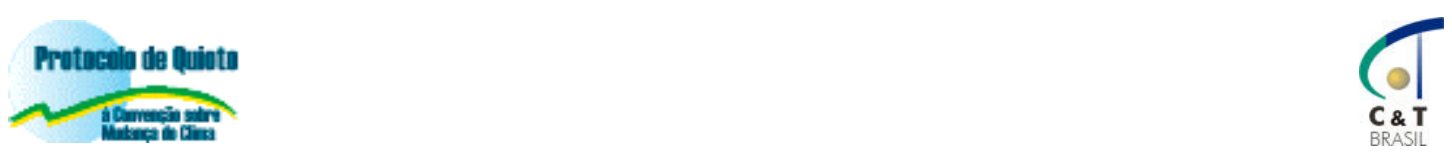

5. A Conferência das Partes na qualidade de reunião das Partes deste Protocolo deve, com a assistência do Órgão Subsidiário de Implementação e, conforme o caso, do Órgão de Assessoramento Científico e Tecnológico, considerar:

(a) As informações submetidas pelas Partes segundo o Artigo 7 e os relatórios das revisões dos especialistas sobre essas informações, elaborados de acordo com este Artigo; e

(b) As questões de implementação listadas pelo Secretariado em conformidade com o parágrafo 3 acima, bem como qualquer questão levantada pelas Partes.

6. A Conferência das Partes na qualidade de reunião das Partes deste Protocolo deve tomar decisões sobre qualquer assunto necessário para a implementação deste Protocolo de acordo com as considerações feitas sobre as informações a que se refere o parágrafo 5 acima.

\section{ARTIGO 9}

1. A Conferência das Partes na qualidade de reunião das Partes deste Protocolo deve rever periodicamente este Protocolo à luz das melhores informações e avaliações científicas disponíveis sobre a mudança do clima e seus impactos, bem como de informações técnicas, sociais e econômicas relevantes. Tais revisões devem ser coordenadas com revisões pertinentes segundo a Convenção, em particular as dispostas no Artigo 4, parágrafo 2(d), e Artigo 7, parágrafo 2(a), da Convenção. Com base nessas revisões, a Conferência das Partes na qualidade de reunião das Partes deste Protocolo deve tomar as providências adequadas.

2. A primeira revisão deve acontecer na segunda sessão da Conferência das Partes na qualidade de reunião das Partes deste Protocolo. Revisões subseqüentes devem acontecer em intervalos regulares e de maneira oportuna.

\section{ARTIGO 10}

Todas as Partes, levando em conta suas responsabilidades comuns mas diferenciadas e suas prioridades de desenvolvimento, objetivos e circunstâncias específicos, nacionais e regionais, sem a introdução de qualquer novo compromisso para as Partes não incluídas no Anexo I, mas reafirmando os compromissos existentes no Artigo 4, parágrafo 1, da Convenção, e continuando a fazer avançar a implementação desses compromissos a fim de atingir o desenvolvimento sustentável, levando em conta o Artigo 4, parágrafos 3, 5 e 7, da Convenção, devem:

(a) Formular, quando apropriado e na medida do possível, programas nacionais e, conforme o caso, regionais adequados, eficazes em relação aos custos, para melhorar a qualidade dos fatores de emissão, dados de atividade e/ou modelos locais que reflitam as condições socioeconômicas de cada Parte para a preparação e atualização periódica de inventários nacionais de emissões antrópicas por fontes e remoções antrópicas por sumidouros de todos os gases de efeito estufa não controlados pelo Protocolo de Montreal, empregando metodologias comparáveis a serem acordadas pela Conferência das Partes e consistentes com as diretrizes para a preparação de comunicações nacionais adotadas pela Conferência das Partes; 

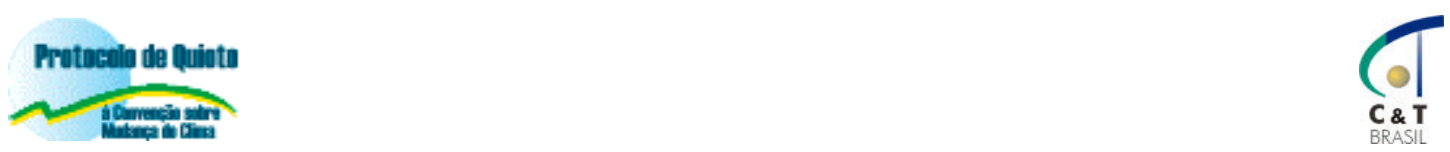

(b) Formular, implementar, publicar e atualizar regularmente programas nacionais e, conforme o caso, regionais, que contenham medidas para mitigar a mudança do clima bem como medidas para facilitar uma adaptação adequada à mudança do clima:

(i) Tais programas envolveriam, entre outros, os setores de energia, transporte e indústria, bem como os de agricultura, florestas e tratamento de resíduos. Além disso, tecnologias e métodos de adaptação para aperfeiçoar o planejamento espacial melhorariam a adaptação à mudança do clima; e

(ii) As Partes incluídas no Anexo I devem submeter informações sobre ações no âmbito deste Protocolo, incluindo programas nacionais, em conformidade com o Artigo 7; e as outras Partes devem buscar incluir em suas comunicações nacionais, conforme o caso, informações sobre programas que contenham medidas que a Parte acredite contribuir para enfrentar a mudança do clima e seus efeitos adversos, incluindo aredução dos aumentos das emissões de gases de efeito estufa e aumento dos sumidouros e remoções, capacitação e medidas de adaptação;

(c) Cooperar na promoção de modalidades efetivas para o desenvolvimento, a aplicação e a difusão, e tomar todas as medidas possíveis para promover, facilitar e financiar, conforme o caso, a transferência ou o acesso a tecnologias, know-how, práticas e processos ambientalmente seguros relativos à mudança do clima, em particular para os países em desenvolvimento, incluindo a formulação de políticas e programas para a transferência efetiva de tecnologias ambientalmente seguras que sejam de propriedade pública ou de domínio público e a criação, no setor privado, de um ambiente propício para promover e melhorar a transferência de tecnologias ambientalmente seguras e o acesso a elas;

(d) Cooperar nas pesquisas científicas e técnicas e promover a manutenção e o desenvolvimento de sistemas de observação sistemática e o desenvolvimento de arquivos de dados para reduzir as incertezas relacionadas ao sistema climático, os efeitos adversos da mudança do clima e as conseqüências econômicas e sociais das várias estratégias de resposta e promover o desenvolvimento e o fortalecimento da capacidade e dos recursos endógenos para participar dos esforços, programas e redes internacionais e intergovernamentais de pesquisa e observação sistemática, levando em conta o Artigo 5 da Convenção;

(e) Cooperar e promover em nível internacional e, conforme o caso, por meio de organismos existentes, a elaboração e a execução de programas de educação e treinamento, incluindo o fortalecimento da capacitação nacional, em particular a capacitação humana e institucional e o intercâmbio ou cessão de pessoal para treinar especialistas nessas áreas, em particular para os países em desenvolvimento, e facilitar em nível nacional a conscientização pública e o acesso público a informações sobre a mudança do clima. Modalidades adequadas devem ser desenvolvidas para implementar essas atividades por meio dos órgãos apropriados da Convenção, levando em conta o Artigo 6 da Convenção;

(f) Incluir em suas comunicações nacionais informações sobre programas eatividades empreendidos em conformidade com este Artigo de acordo com as decisões pertinentes da Conferência das Partes; e

(g) Levar plenamente em conta, na implementação dos compromissos previstos neste Artigo, o Artigo 4, parágrafo 8, da Convenção. 


\section{ARTIGO 11}

1. Na implementação do Artigo 10, as Partes devem levar em conta as disposições do Artigo 4, parágrafos $4,5,7,8$ e 9, da Convenção.

2. No contexto da implementação do Artigo 4, parágrafo 1, da Convenção, em conformidade com as disposições do Artigo 4, parágrafo 3, e do Artigo 11 da Convenção, e por meio da entidade ou entidades encarregadas da operação do mecanismo financeiro da Convenção, as Partes países desenvolvidos e as demais Partes desenvolvidas incluídas no Anexo II da Convenção devem:

(a) Prover recursos financeiros novos e adicionais para cobrir integralmente os custos por elas acordados incorridos pelas Partes países em desenvolvimento para fazer avançar a implementação dos compromissos assumidos sob o Artigo 4, parágrafo 1(a), da Convenção e previstos no Artigo 10, alínea (a); e

(b) Também prover esses recursos financeiros, inclusive para a transferência de tecnologia, de que necessitem as Partes países em desenvolvimento para cobrir integralmente os custos incrementais para fazer avançar a implementação dos compromissos existentes sob o Artigo 4, parágrafo 1, da Convenção e descritos no Artigo 10 e que sejam acordados entre uma Parte país em desenvolvimento e a entidade ou entidades internacionais a que se refere o Artigo 11 da Convenção, em conformidade com esse Artigo.

A implementação desses compromissos existentes deve levar em conta a necessidade de que o fluxo de recursos financeiros seja adequado e previsível e a importância da divisão adequada do ônus entre as Partes países desenvolvidos. A orientação para a entidade ou entidades encarregadas da operação do mecanismo financeiro da Convençãoem decisões pertinentes da Conferência das Partes, incluindo as acordadas antes da adoção deste Protocolo, aplica-se mutatis mutandis às disposições deste parágrafo.

3. As Partes países desenvolvidos e demais Partes desenvolvidas do Anexo II da Convenção podem também prover recursos financeiros para a implementação do Artigo 10 por meio de canais bilaterais, regionais e multilaterais e as Partes países em desenvolvimento podem deles beneficiarse.

\section{ARTIGO 12}

1. Fica definido um mecanismo de desenvolvimento limpo.

2. O objetivo do mecanismo de desenvolvimento limpo deve ser assistir às Partes não incluídas no Anexo I para que atinjam o desenvolvimento sustentável e contribuam para o objetivo final da Convenção, e assistir às Partes incluídas no Anexo I para que cumpram seus compromissos quantificados de limitação e redução de emissões, assumidos no Artigo 3.

3. Sob o mecanismo de desenvolvimento limpo:

(a) As Partes não incluídas no Anexo I beneficiar-se-ão de atividades de projetos que resultem em reduções certificadas de emissões; e 

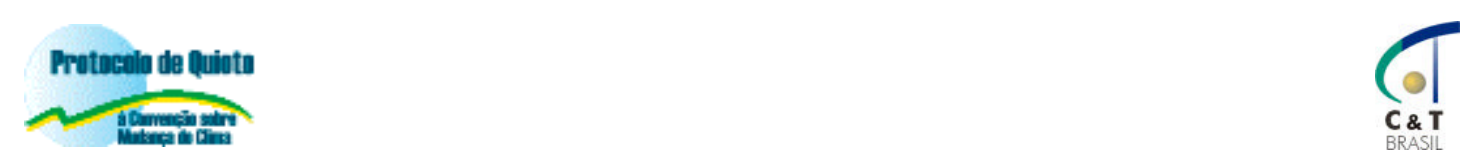

(b) As Partes incluídas no Anexo I podem utilizar as reduções certificadas de emissões, resultantes de tais atividades de projetos, para contribuir com o cumprimento de parte de seus compromissos quantificados de limitação e redução de emissões, assumidos no Artigo 3, como determinado pela Conferência das Partes na qualidade de reunião das Partes deste Protocolo.

4. O mecanismo de desenvolvimento limpo deve sujeitar-se à autoridade e orientação da Conferência das Partes na qualidade de reunião das Partes deste Protocolo e à supervisão de um conselho executivo do mecanismo de desenvolvimento limpo.

5. As reduções de emissões resultantes de cada atividade de projeto devem ser certificadas por entidades operacionais a serem designadas pela Conferência das Partesna qualidade de reunião das Partes deste Protocolo, com base em:

(a) Participação voluntária aprovada por cada Parte envolvida;

(b) Benefícios reais, mensuráveis e de longo prazo relacionados com a mitigação da mudança do clima, e

(c) Reduções de emissões que sejam adicionais as que ocorreriam na ausência da atividade certificada de projeto.

6. O mecanismo de desenvolvimento limpo deve prestar assistência quanto à obtenção de fundos para atividades certificadas de projetos quando necessário.

7. A Conferência das Partes na qualidade de reunião das Partes deste Protocolo deve, em sua primeira sessão, elaborar modalidades e procedimentos com o objetivo de assegurar transparência, eficiência e prestação de contas das atividades de projetos por meio de auditorias e verificações independentes.

8. A Conferência das Partes na qualidade de reunião das Partes deste Protocolo deve assegurar que uma fração dos fundos advindos de atividades de projetos certificadas seja utilizada para cobrir despesas administrativas, assim como assistir às Partes países em desenvolvimento que sejam particularmente vulneráveis aos efeitos adversos da mudança do clima para fazer face aos custos de adaptação.

9. A participação no mecanismo de desenvolvimento limpo, incluindo nas atividades mencionadas no parágrafo 3(a) acima e na aquisição de reduções certificadas de emissão, pode envolver entidades privadas e/ou públicas e deve sujeitar-se a qualquer orientação que possa ser dada pelo conselho executivo do mecanismo de desenvolvimento limpo.

10. Reduções certificadas de emissões obtidas durante o período do ano 2000 até o início do primeiro período de compromisso podem ser utilizadas para auxiliar no cumprimento das responsabilidades relativas ao primeiro período de compromisso. 

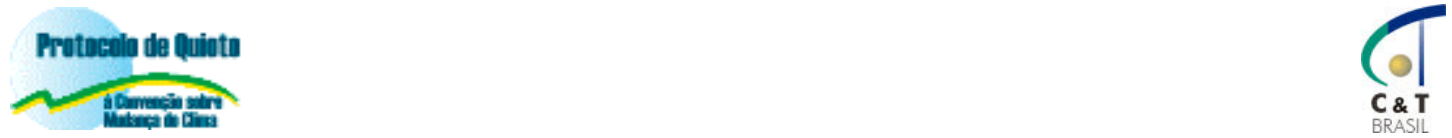

\section{ARTIGO 13}

1. A Conferência das Partes, o órgão supremo da Convenção, deve atuar na qualidadede reunião das Partes deste Protocolo.

2. As Partes da Convenção que não sejam Partes deste Protocolo podem participar como observadoras das deliberações de qualquer sessão da Conferência das Partes na qualidade de reunião das Partes deste Protocolo. Quando a Conferência das Partes atuar na qualidade de reunião das Partes deste Protocolo, as decisões tomadas sob este Protocolo devem ser tomadas somente por aquelas que sejam Partes deste Protocolo.

3. Quando a Conferência das Partes atuar na qualidade de reunião das Partes deste Protocolo, qualquer membro da Mesa da Conferência das Partes representando uma Parte da Convenção mas, nessa ocasião, não uma Parte deste Protocolo, deve ser substituído por um outro membro, escolhido entre as Partes deste Protocolo e por elas eleito.

4. A Conferência das Partes na qualidade de reunião das Partes deste Protocolo deve manter a implementação deste Protocolo sob revisão periódica e tomar, dentro de seu mandato, as decisões necessárias para promover a sua implementação efetiva. Deve executar as funções a ela atribuídas por este Protocolo e deve:

(a) Com base em todas as informações apresentadas em conformidade com as disposições deste Protocolo, avaliar a implementação deste Protocolo pelas Partes, os efeitos gerais das medidas tomadas de acordo com este Protocolo, em particular os efeitos ambientais, econômicos e sociais, bem como os seus efeitos cumulativos e o grau de progresso no atendimento do objetivo da Convenção;

(b) Examinar periodicamente as obrigações das Partes deste Protocolo, com a devida consideração a qualquer revisão exigida pelo Artigo 4, parágrafo 2(d), e Artigo 7, parágrafo 2, da Convenção, à luz do seu objetivo, da experiência adquirida em sua implementação e da evolução dos conhecimentos científicos e tecnológicos, e a esse respeito, considerar e adotar relatórios periódicos sobre a implementação deste Protocolo;

(c) Promover e facilitar o intercâmbio de informações sobre medidas adotadas pelas Partes para enfrentar a mudança do clima e seus efeitos, levando emconta as diferentes circunstâncias, responsabilidades e recursos das Partes e seus respectivos compromissos assumidos sob este Protocolo;

(d) Facilitar, mediante solicitação de duas ou mais Partes, a coordenação de medidas por elas adotadas para enfrentar a mudança do clima e seus efeitos, levando em conta as diferentes circunstâncias, responsabilidades e capacidades das Partes e seus respectivos compromissos assumidos sob este Protocolo;

(e) Promover e orientar, em conformidade com o objetivo da Convenção e as disposições deste Protocolo, e levando plenamente em conta as decisões pertinentes da Conferência das Partes, o desenvolvimento e aperfeiçoamento periódico de metodologias comparáveis para a implementação efetiva deste Protocolo, a serem acordadas pela Conferência das Partes na qualidade de reunião das Partes deste Protocolo;

(f) Fazer recomendações sobre qualquer assunto necessário à implementação deste Protocolo; 

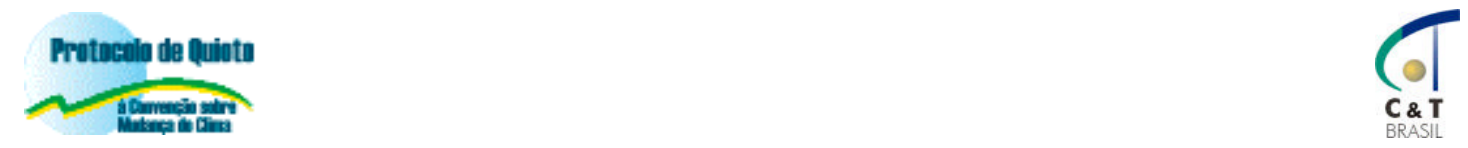

(g) Procurar mobilizar recursos financeiros adicionais em conformidade com o Artigo 11, parágrafo 2;

(h) Estabelecer os órgãos subsidiários considerados necessários à implementação deste Protocolo;

(i) Buscar e utilizar, conforme o caso, os serviços e a cooperação das organizações internacionais e dos organismos intergovernamentais e não-governamentais competentes, bem como as informações por eles fornecidas; e

(j) Desempenhar as demais funções necessárias à implementação deste Protocolo e considerar qualquer atribuição resultante de uma decisão da Conferência das Partes.

5. As regras de procedimento da Conferência das Partes e os procedimentos financeiros aplicados sob a Convenção devem ser aplicados mutatis mutandis sob este Protocolo, exceto quando decidido de outra forma por consenso pela Conferência das Partes na qualidade de reunião das Partes deste Protocolo.

6. A primeira sessão da Conferência das Partes na qualidade de reunião das Partes deste Protocolo deve ser convocada pelo Secretariado juntamente com a primeira sessão da Conferência das Partes programada para depois da data de entrada em vigor deste Protocolo. As sessões ordinárias subseqüentes da Conferência das Partes na qualidade de reunião das Partes deste Protocolo devem ser realizadas anualmente e em conjunto com as sessões ordinárias da Conferência das Partes a menos que decidido de outra forma pela Conferência das Partes na qualidade de reunião das Partes deste Protocolo.

7. As sessões extraordinárias da Conferência das Partes na qualidade de reunião das Partes deste Protocolo devem ser realizadas em outras datas quando julgado necessário pela Conferência das Partes na qualidade de reunião das Partes deste Protocolo, ou por solicitação escrita de qualquer Parte, desde que, dentro de seis meses após a solicitação ter sido comunicada às Partes pelo Secretariado, receba o apoio de pelo menos um terço das Partes.

8. As Nações Unidas, seus órgãos especializados e a Agência Internacional de Energia Atômica, bem como qualquer Estado-Membro dessas organizações ou observador junto às mesmas que não seja Parte desta Convenção podem se fazer representar como observadores nas sessões da Conferência das Partes na qualidade de reunião das Partes deste Protocolo. Qualquer outro órgão ou agência, nacional ou internacional, governamental ou não-governamental, competente em assuntos de que trata este Protocolo e que tenha informado ao Secretariado o seu desejo de se fazer representar como observador numa sessão da Conferência das Partes na qualidade de reunião das Partes deste Protocolo, pode ser admitido nessa qualidade, salvo se pelo menos um terço das Partes presentes objete. A admissão e participação dos observadores devem sujeitar-se às regras de procedimento a que se refere o parágrafo 5 acima. 

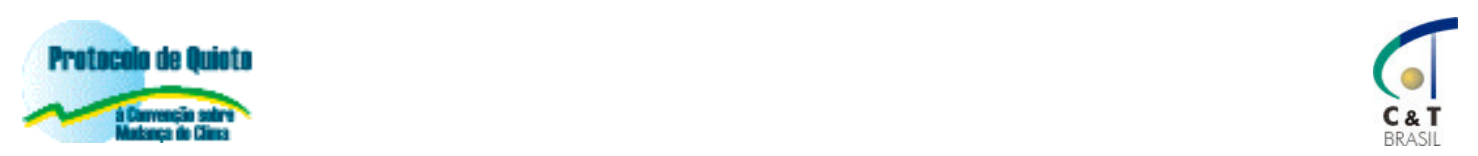

\section{ARTIGO 14}

1. O Secretariado estabelecido pelo Artigo 8 da Convenção deve desempenhar a funçãode Secretariado deste Protocolo.

2. O Artigo 8, parágrafo 2, da Convenção, sobre as funções do Secretariado e o Artigo 8, parágrafo 3 , da Convenção, sobre as providências tomadas para o seu funcionamento, devem ser aplicados mutatis mutandis a este Protocolo. O Secretariado deve, além disso, exercer as funções a ele atribuídas sob este Protocolo.

\section{ARTIGO 15}

1. O Órgão Subsidiário de Assessoramento Científico e Tecnológico e o Órgão Subsidiário de Implementação estabelecidos nos Artigos 9 e 10 da Convenção devem atuar, respectivamente, como o Órgão Subsidiário de Assessoramento Científico e Tecnológico e o Órgão Subsidiário de Implementação deste Protocolo. As disposições relacionadas com o funcionamento desses dois órgãos sob a Convenção devem ser aplicadas mutatis mutandis a este Protocolo. As sessões das reuniões do Órgão Subsidiário de Assessoramento Científico e Tecnológico e do Órgão Subsidiário de Implementação deste Protocolo devem ser realizadas conjuntamente com as reuniões do Órgão Subsidiário de Assessoramento Científico e Tecnológico e do Órgão Subsidiário de Implementação da Convenção, respectivamente.

2. As Partes da Convenção que não são Partes deste Protocolo podem participar como observadoras das deliberações de qualquer sessão dos órgãos subsidiários. Quando os órgãos subsidiários atuarem como órgãos subsidiários deste Protocolo, as decisões sob este Protocolo devem ser tomadas somente por aquelas que sejam Partes deste Protocolo.

3. Quando os órgãos subsidiários estabelecidos pelos Artigos 9 e 10 da Convenção exerçam suas funções com relação a assuntos que dizem respeito a este Protocolo, qualquer membro das Mesas desses órgãos subsidiários representando uma Parte da Convenção, mas nessa ocasião, não uma Parte deste Protocolo, deve ser substituído por um outro membro escolhido entre as Partes deste Protocolo e por elas eleito.

\section{ARTIGO 16}

A Conferência das Partes na qualidade de reunião das Partes deste Protocolo deve, tão logo seja possível, considerar a aplicação a este Protocolo, e modificação conforme o caso, do processo multilateral de consultas a que se refere o Artigo 13 da Convenção, à luz de qualquer decisão pertinente que possa ser tomada pela Conferência das Partes. Qualquer processo multilateral de consultas que possa ser aplicado a este Protocolo deve operar sem prejuízo dos procedimentos e mecanismos estabelecidos em conformidade com o Artigo 18.

\section{ARTIGO 17}

A Conferência das Partes deve definir os princípios, as modalidades, regras e diretrizes apropriados, em particular para verificação, elaboração de relatórios e prestação de contas do comércio de emissões. As Partes incluídas no Anexo B podem participar do comércio de emissões com o objetivo de cumprir os compromissos assumidos sob o Artigo 3. Tal comércio deve ser suplementar às ações domésticas com vistas a atender os compromissos quantificados de limitação e redução de emissões, assumidos sob esse Artigo. 


\section{ARTIGO 18}

A Conferência das Partes na qualidade de reunião das Partes deste Protocolo deve, em sua primeira sessão, aprovar procedimentos e mecanismos adequados e eficazes para determinar e tratar de casos de não-cumprimento das disposições deste Protocolo, inclusive por meio do desenvolvimento de uma lista indicando possíveis conseqüências, levando em conta a causa, o tipo, o grau e a freqüência do não-cumprimento. Qualquer procedimento e mecanismo sob este Artigo que acarrete conseqüências de caráter vinculante deve ser adotado por meio de uma emenda a este Protocolo.

\section{ARTIGO 19}

As disposições do Artigo 14 da Convenção sobre a solução de controvérsias aplicam-se mutatis mutandis a este Protocolo.

\section{ARTIGO 20}

\section{Qualquer Parte pode propor emendas a este Protocolo.}

2. As emendas a este Protocolo devem ser adotadas em sessão ordinária da Conferência das Partes na qualidade de reunião das Partes deste Protocolo. O texto de qualquer emenda proposta a este Protocolo deve ser comunicado às Partes pelo Secretariado pelo menos seis meses antes da sessão em que será proposta sua adoção. O texto de qualquer emenda proposta deve também ser comunicado pelo Secretariado às Partes e aos signatários da Convenção e, para informação, ao Depositário.

3. As Partes devem fazer todo o possível para chegar a acordo por consenso sobre qualquer emenda proposta a este Protocolo. Uma vez exauridos todos os esforços para chegar a um consenso sem que se tenha chegado a um acordo, a emenda deve ser adotada, em última instância, por maioria de três quartos dos votos das Partes presentes e votantes na sessão. A emenda adotada deve ser comunicada pelo Secretariado ao Depositário, que deve comunicá-la a todas as Partes para aceitação.

4. Os instrumentos de aceitação em relação a uma emenda devem ser depositados junto ao Depositário. Uma emenda adotada, em conformidade com o parágrafo 3 acima, deve entrar em vigor para as Partes que a tenham aceito no nonagésimo dia após a data de recebimento, pelo Depositário, dos instrumentos de aceitação de pelo menos três quartos das Partes deste Protocolo.

5. A emenda deve entrar em vigor para qualquer outra Parte no nonagésimo dia após a data em que a Parte deposite, junto ao Depositário, seu instrumento de aceitação de tal emenda.

\section{ARTIGO 21}

1. Os anexos deste Protocolo constituem parte integrante do mesmo e, salvo se expressamente disposto de outro modo, qualquer referência a este Protocolo constitui ao mesmo tempo referência a qualquer de seus anexos. Qualquer anexo adotado após aentrada em vigor deste Protocolo deve conter apenas listas, formulários e qualquer outro material de natureza descritiva que trate de assuntos de caráter científico, técnico, administrativo ou de procedimento. 

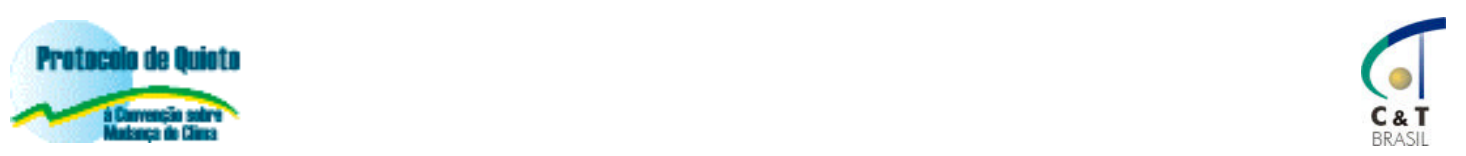

2. Qualquer Parte pode elaborar propostas de anexo para este Protocolo e propor emendas a anexos deste Protocolo.

3. Os anexos deste Protocolo e as emendas a anexos deste Protocolo devem ser adotados em sessão ordinária da Conferência das Partes na qualidade de reunião das Partes deste Protocolo. O texto de qualquer proposta de anexo ou de emenda a um anexo deve ser comunicado às Partes pelo Secretariado pelo menos seis meses antes da reunião em que será proposta sua adoção. $\mathrm{O}$ texto de qualquer proposta de anexo ou de emenda a um anexo deve também ser comunicado pelo Secretariado às Partes e aos signatários da Convenção e, para informação, ao Depositário.

4. As Partes devem fazer todo o possível para chegar a acordo por consenso sobre qualquer proposta de anexo ou de emenda a um anexo. Uma vez exauridos todos os esforços para chegar a um consenso sem que se tenha chegado a um acordo, o anexo ou a emenda a um anexo devem ser adotados, em última instância, por maioria de três quartos dos votos das Partes presentes e votantes na sessão. Os anexos ou emendas a um anexo adotados devem ser comunicados pelo Secretariado ao Depositário, que deve comunicá-los a todas as Partes para aceitação.

5. Um anexo, ou emenda a um anexo, que não Anexo $\mathrm{A}$ ou $\mathrm{B}$, que tenha sido adotado em conformidade com os parágrafos 3 e 4 acima deve entrar em vigor para todas as Partes deste Protocolo seis meses após a data de comunicação a essas Partes, pelo Depositário, da adoção do anexo ou da emenda ao anexo, à exceção das Partes que notificarem o Depositário, por escrito, e no mesmo prazo, de sua não-aceitação do anexo ou da emenda ao anexo. O anexo ou a emenda a um anexo devem entrar em vigor para as Partes que tenham retirado sua notificação de não-aceitação no nonagésimo dia após a data de recebimento, pelo Depositário, da retirada dessa notificação.

6. Se a adoção de um anexo ou de uma emenda a um anexo envolver uma emenda a este Protocolo, esse anexo ou emenda a um anexo não deve entrar em vigor até que entre em vigor a emenda a este Protocolo.

7. As emendas aos Anexos A e B deste Protocolo devem ser adotadas e entrar em vigor em conformidade com os procedimentos descritos no Artigo 20, desde que qualquer emenda ao Anexo B seja adotada mediante o consentimento por escrito da Parte envolvida.

\section{ARTIGO 22}

1. Cada Parte tem direito a um voto, à exceção do disposto no parágrafo 2 abaixo.

2. As organizações regionais de integração econômica devem exercer, em assuntos de sua competência, seu direito de voto com um número de votos igual ao número de seus EstadosMembros Partes deste Protocolo. Essas organizações não devem exercer seu direito de voto se qualquer de seus Estados-Membros exercer esse direito e vice-versa.

\section{ARTIGO 23}

O Secretário-Geral das Nações Unidas será o Depositário deste Protocolo. 

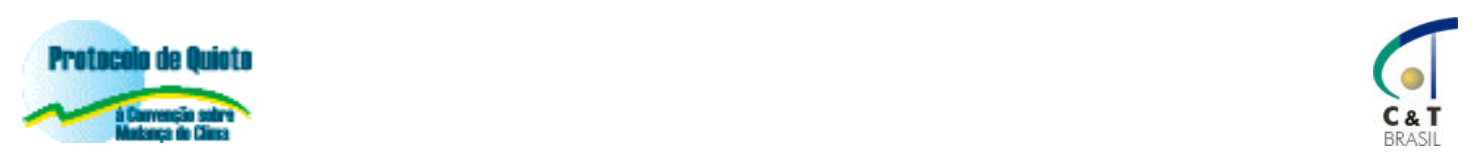

\section{ARTIGO 24}

1. Este Protocolo estará aberto a assinatura e sujeito a ratificação, aceitação ou aprovação de Estados e organizações regionais de integração econômica que sejam Partes da Convenção. Estará aberto a assinatura na sede das Nações Unidas em Nova York de 16 de março de 1998 a 15 de março de 1999. Este Protocolo estará aberto a adesões a partir do dia seguinte à data em que não mais estiver aberto a assinaturas. Os instrumentos de ratificação, aceitação, aprovação ou adesão devem ser depositados junto ao Depositário.

2. Qualquer organização regional de integração econômica que se torne Parte deste Protocolo, sem que nenhum de seus Estados-Membros seja Parte, deve sujeitar-se a todas as obrigações previstas neste Protocolo. No caso de um ou mais Estados-Membros dessas organizações serem Partes deste Protocolo, a organização e seus Estados-Membros devem decidir sobre suas respectivas responsabilidades pelo desempenho de suas obrigações previstas neste Protocolo. Nesses casos, as organizações e os Estados-Membros não podem exercer simultaneamente direitos estabelecidos por este Protocolo.

3. Em seus instrumentos de ratificação, aceitação, aprovação ou adesão, as organizações regionais de integração econômica devem declarar o âmbito de suas competências no tocante a assuntos regidos por este Protocolo. Essas organizações devem também informar ao Depositário qualquer modificação substancial no âmbito de suas competências, o qual, por sua vez, deve transmitir essas informações às Partes.

\section{ARTIGO 25}

1. Este Protocolo entra em vigor no nonagésimo dia após a data em que pelo menos 55 Partes da Convenção, englobando as Partes incluídas no Anexo I que contabilizaram no total pelo menos 55 por cento das emissões totais de dióxido de carbono em 1990 das Partes incluídas no Anexo I, tenham depositado seus instrumentos de ratificação, aceitação, aprovação ou adesão.

2. Para os fins deste Artigo, "as emissões totais de dióxido de carbono em 1990 das Partes incluídas no Anexo I" significa a quantidade comunicada anteriormente ou na data de adoção deste Protocolo pelas Partes incluídas no Anexo I em sua primeira comunicação nacional, submetida em conformidade com o Artigo 12 da Convenção.

3. Para cada Estado ou organização regional de integração econômica que ratifique, aceite, aprove ou adira a este Protocolo após terem sido reunidas as condições para entrada em vigor descritas no parágrafo 1 acima, este Protocolo entra em vigor no nonagésimo dia após a data de depósito de seu instrumento de ratificação, aceitação, aprovação ou adesão.

4. Para os fins deste Artigo, qualquer instrumento depositado por uma organização regional de integração econômica não deve ser considerado como adicional aos depositados por EstadosMembros da organização.

\section{ARTIGO 26}

Nenhuma reserva pode ser feita a este Protocolo. 

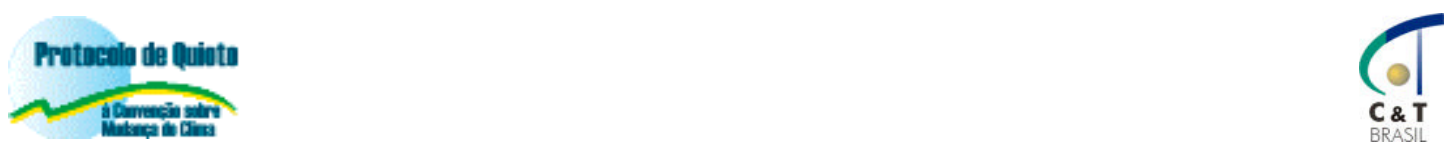

\section{ARTIGO 27}

1. Após três anos da entrada em vigor deste Protocolo para uma Parte, essa Parte pode, a qualquer momento, denunciá-lo por meio de notificação por escrito ao Depositário.

2. Essa denúncia tem efeito um ano após a data de recebimento pelo Depositário da notificação de denúncia, ou em data posterior se assim nela for estipulado.

3. Deve ser considerado que qualquer Parte que denuncie a Convenção denuncia também este Protocolo.

\section{ARTIGO 28}

O original deste Protocolo, cujos textos em árabe, chinês, inglês, francês, russo e espanhol são igualmente autênticos, deve ser depositado junto ao Secretário-Geral das Nações Unidas.

FEITO em Quioto aos onze dias de dezembro de mil novecentos e noventa e sete.

EM FÉ DO QUE, os abaixo assinados, devidamente autorizados para esse fim, firmam este Protocolo nas datas indicadas. 


\section{ANEXO A}

\section{Gases de efeito estufa}

Dióxido de carbono (CO2)

Metano (CH4)

Óxido nitroso (N2O)

Hidrofluorcarbonos (HFCs)

Perfluorcarbonos (PFCs)

Hexafluoreto de enxofre (SF6)

\section{Setores/categorias de fontes}

Energia

Queima de combustível

Setor energético

Indústrias de transformação e de construção

Transporte

Outros setores

Outros

Emissões fugitivas de combustíveis

Combustíveis sólidos

Petróleo e gás natural

Outros

Processos industriais

Produtos minerais

Indústria química

Produção de metais

Outras produções

Produção de halocarbonos e hexafluoreto de enxofre

Consumo de halocarbonos e hexafluoreto de enxofre

Outros

Uso de solventes e outros produtos

Agricultura

Fermentação entérica

Tratamento de dejetos

Cultivo de arroz

Solos agrícolas

Queimadas prescritas de savana

Queima de resíduos agrícolas

Outros

\section{Resíduos}

Disposição de resíduos sólidos na terra

Tratamento de esgoto

Incineração de resíduos

Outros 


\section{ANEXO B}

Parte

Compromisso de redução ou limitação quantificada de emissões

(porcentagem do ano base ou período)

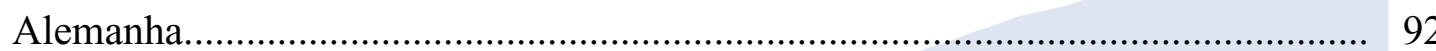

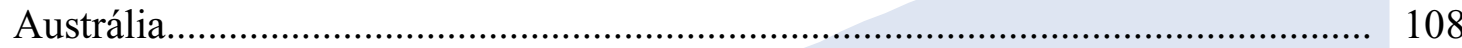

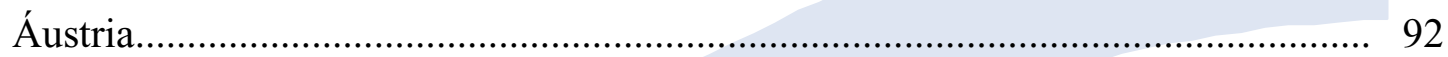

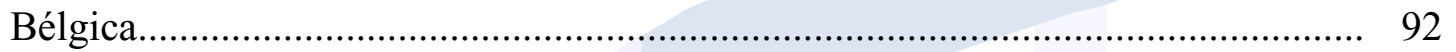

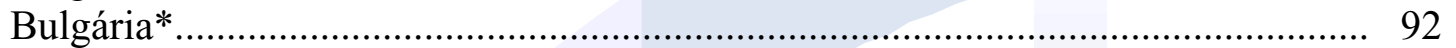

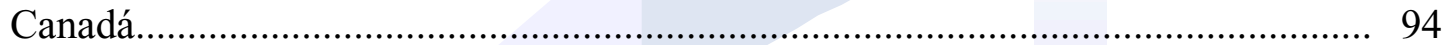

Comunidade Européia............................................................................... 92

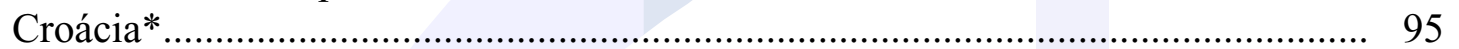

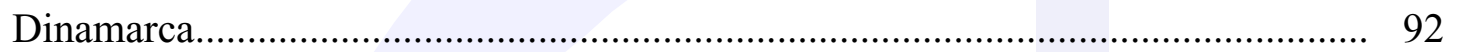

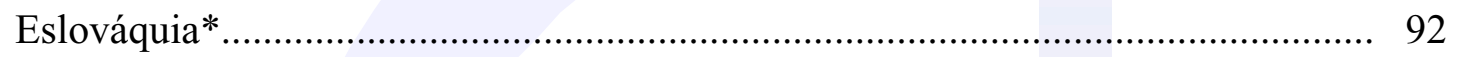

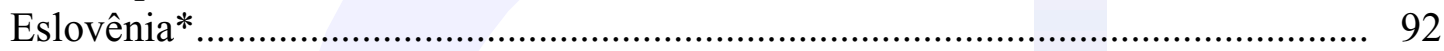

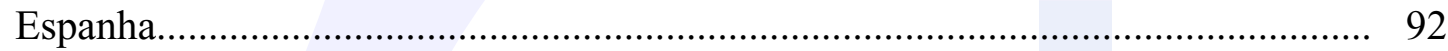

Estados Unidos da América.............................................................................. 93

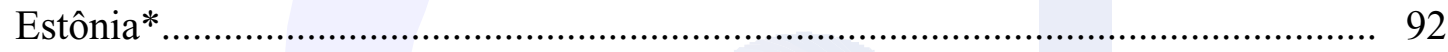

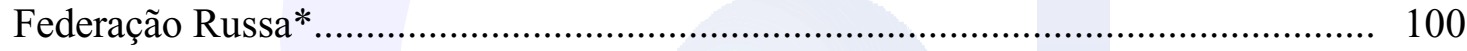

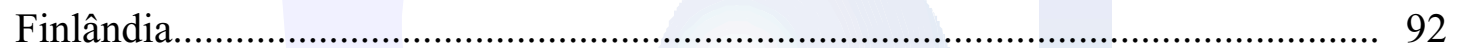

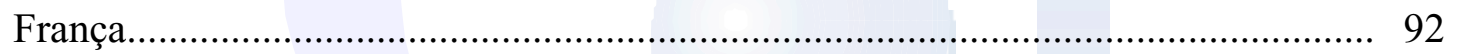

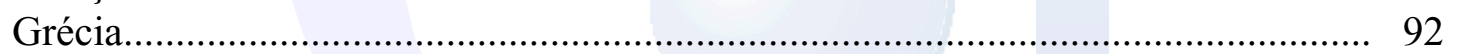

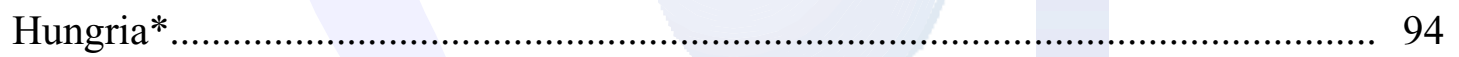

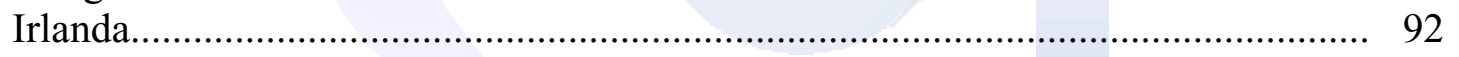

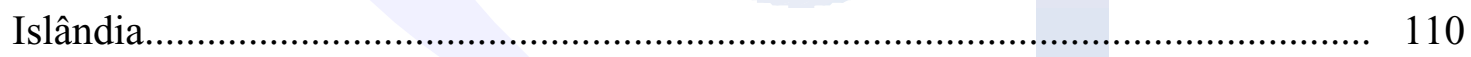

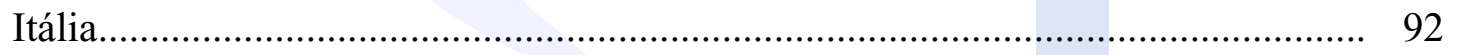

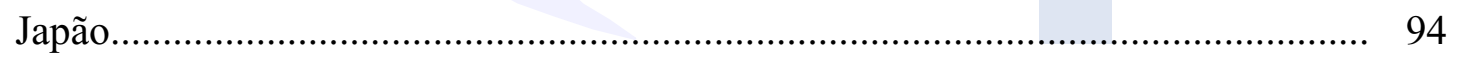

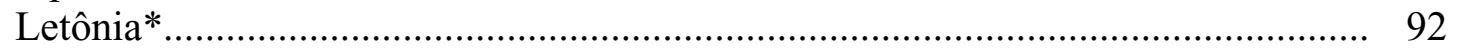

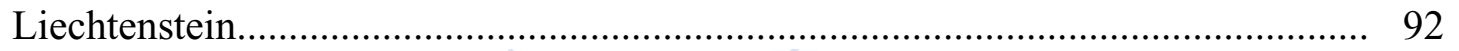

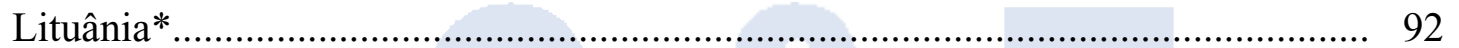

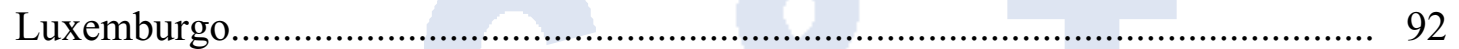

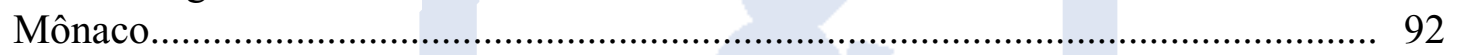

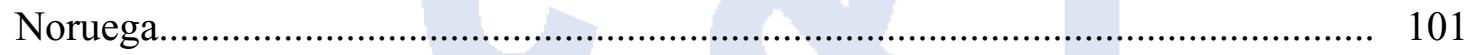

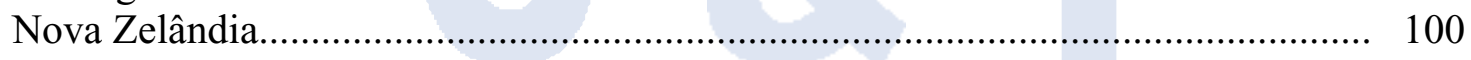

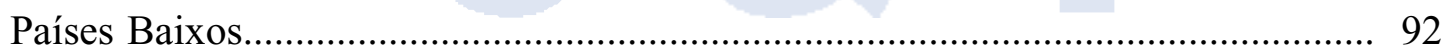

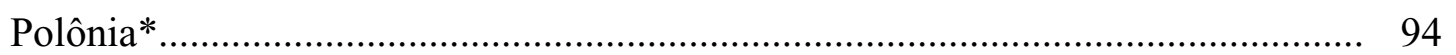

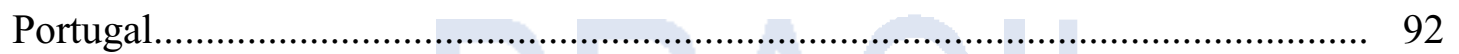

Reino Unido da Grã-Bretanha e Irlanda do Norte................................................... 92

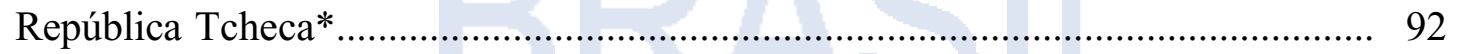

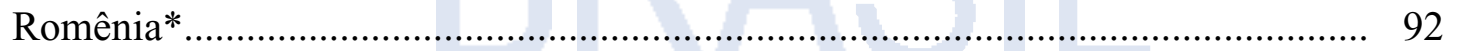

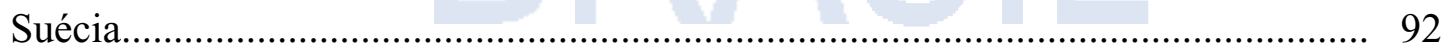

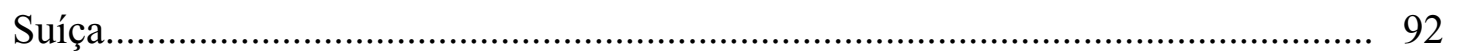

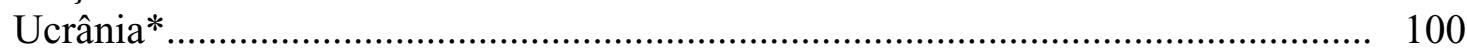

* Países em processo de transição para uma economia de mercado. 


\title{
DECISÕES ADOTADAS PELA CONFERÊNCIA DAS PARTES \\ $\left(12^{\mathrm{a}}\right.$ sessão plenária, 11 de dezembro de 1997)
}

\author{
Decisão 1/CP.3 \\ Adoção do Protocolo de Quioto à \\ Convenção-Quadro das Nações Unidas sobre Mudança do Clima
}

\section{A Conferência das Partes,}

Tendo revisto o Artigo 4, parágrafo 2(a) e (b) da Convenção-Quadro das Nações Unidas sobre Mudança do Clima em sua primeira sessão e tendo concluído que essas alíneas não são adequadas,

Lembrando sua decisão 1/CP.1 intitulada "O Mandato de Berlim: revisão da adequação do artigo 4, parágrafo 2(a) e (b), da Convenção, incluindo propostas relacionadas a um protocolo e decisões sobre acompanhamento", por meio da qual acordou em iniciar um processo que a possibilitasse tomar as ações apropriadas para o período após 2000 por meio da adoção de um protocolo ou outro instrumento legal em sua terceira sessão,

Lembrando ainda que um dos objetivos do processo foi o de fortalecer os compromissos contidos no Artigo 4, parágrafo 2(a) e (b) da Convenção, para que os países desenvolvidos/outras Partes incluídas no Anexo I, tanto elaborassem políticas e medidas como definissem objetivos quantificados de limitação e redução dentro de prazos estabelecidos, como 2005, 2010 e 2020, para suas emissões antrópicas por fontes e remoções antrópicas por sumidouros dos gases de efeito estufa não controlados pelo Protocolo de Montreal,

Lembrando também que, de acordo com o Mandato de Berlim, o processo não introduzirá qualquer novo compromisso para as Partes não incluídas no Anexo I, mas reafirmará os compromissos existentes no Artigo 4, parágrafo 1, e continuará fazendo avançar a implementação desses compromissos a fim de atingir o desenvolvimento sustentável, levandoem conta o Artigo 4, parágrafos 3,5 e 7 ,

Observando os relatórios das oito sessões ${ }^{1}$ do Grupo Ad Hoc sobre o Mandato de Berlim,

Tendo considerado com reconhecimento o relatório apresentado pelo Presidente do Grupo Ad Hoc sobre o Mandato de Berlim,

Tomando nota com reconhecimento do relatório do Presidente do Comitê Plenário sobre os resultados do trabalho do Comitê,

Reconhecendo a necessidade de preparar a pronta entrada em vigor do Protocolo de Quioto à Convenção-Quadro das Nações Unidas sobre Mudança do Clima,

Ciente da conveniência do início tempestivo dos trabalhos de forma a abrir caminho para o êxito da quarta sessão da Conferência das Partes, que acontecerá em Buenos Aires, Argentina,

\footnotetext{
${ }^{1}$ FCCC/AGBM/1995/2 e Corr.1 e 7 e Corr.1; FCCC/AGBM/1996/5, 8 e 11; FCCC/AGBM/1997/3, 3/Add.1 e Corr. $1,5,8$ e $8 /$ Add. 1 .
} 

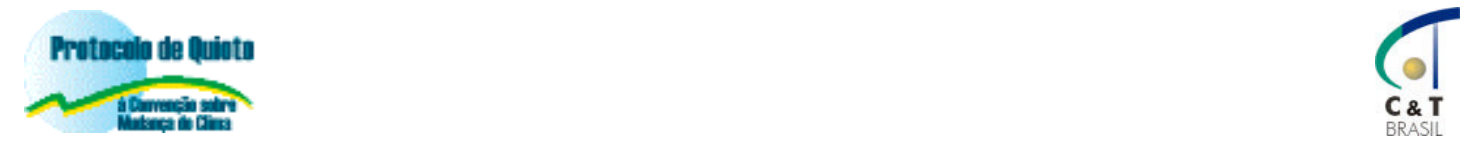

1. Decide adotar o Protocolo de Quioto à Convenção-Quadro das Nações Unidas sobre Mudança do Clima, em anexo;

2. Solicita que o Secretário Geral das Nações Unidas seja o Depositário desse Protocolo, abrindo-o para assinatura em Nova York de 16 de março de 1998 a 15 de março de 1999;

3. Convida todas as Partes da Convenção-Quadro das Nações Unidas sobre Mudança do Clima a assinar o Protocolo no dia 16 de março de 1998 ou na primeira oportunidade subseqüentemente e depositar instrumentos de ratificação, aceitação ou aprovação, ou instrumentos de adesão, conforme o caso, o mais rápido possível;

4. Convida ainda os Estados que não são Partes da Convenção a ratificar ou a ela aderir, conforme o caso, sem demora, a fim de que possam tornar-se Partes do Protocolo;

5. Solicita ao Presidente do Órgão Subsidiário de Assessoramento Científico e Tecnológico e ao Presidente do Órgão Subsidiário de Implementação, levando em conta o orçamento aprovado por programa para o biênio 1998-1999 e o correspondente programa de trabalho do Secretariado ${ }^{2}$, que orientem o Secretariado a respeito do trabalho preparatório necessário para que a Conferência das Partes considere, em sua quarta sessão, as seguintes questões e que distribuam o trabalho aos respectivos órgãos subsidiários conforme o caso:

(a) Determinação de modalidades, regras e diretrizes sobre como e quais atividades adicionais induzidas pelo homem relacionadas a variações nas emissões por fontes e remoções por sumidouros de gases de efeito estufa nas categorias de solos agrícolas e de mudança no uso da terra e florestas devem ser adicionadas, ou subtraídas, das quantidades atribuídas para as Partes do Protocolo incluídas no Anexo I da Convenção, como estabelecido no Artigo 3, parágrafo 4, do Protocolo;

(b) Definição dos princípios, das modalidades, regras e diretrizes apropriados, em particular para verificação, elaboração de relatório e prestação de contas do comércio de emissões, conforme o Artigo 17 do Protocolo;

(c) Elaboração de diretrizes para que qualquer Parte do Protocolo incluída no Anexo I da Convenção transfira ou adquira de qualquer outra dessas Partes unidades de redução de emissão resultantes de projetos com o objetivo de reduzir emissões antrópicas por fontes ou aumentar remoções antrópicas por sumidouros de gases de efeito estufa em qualquer setor da economia, como estabelecido no Artigo 6 do Protocolo;

(d) Consideração e, conforme o caso, adoção de ações sobre metodologias apropriadas para tratar da situação das Partes listadas no Anexo B do Protocolo para as quais projetos isolados teriam um efeito proporcional significativo sobre as emissões no período de compromisso;

(e) Análise das implicações do Artigo 12, parágrafo 10, do Protocolo;

6. Convida o Presidente do Órgão Subsidiário de Assessoramento Científico e Tecnológico e o Presidente do Órgão Subsidiário de Implementação a fazer uma proposta conjunta para esses órgãos, em suas oitavas sessões, sobre a designação a eles de trabalho preparatório para permitir

\footnotetext{
${ }^{2}$ FCCC/CP/1997/INF.1.
} 

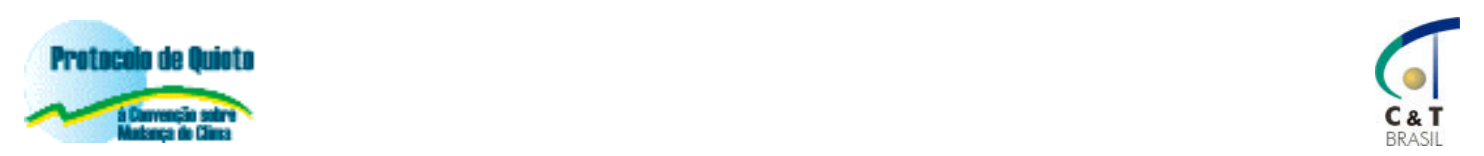

que a Conferência das Partes na qualidade de reunião das Partes do Protocolo, em sua primeira sessão após a entrada em vigor do Protocolo, realize as tarefas a ela atribuídas pelo Protocolo.

\section{Decisão 2/CP.3 \\ Questões metodológicas relacionadas ao Protocolo de Quioto}

\section{A Conferência das Partes,}

Lembrando suas decisões 4/CP.1 e 9/CP.2,

Endossando as conclusões relevantes do Órgão Subsidiário de Assessoramento Científico e Tecnológico em sua quarta sessão, ${ }^{1}$

1. Reafirma que as Partes devem utilizar as Diretrizes Revisadas de 1996 para Inventários Nacionais de Gases de Efeito Estufa do Painel Intergovernamental sobre Mudança do Clima para estimar e relatar as emissões antrópicas por fontes e as remoções antrópicas por sumidouros dos gases de efeito estufa não controlados pelo Protocolo de Montreal;

2. Afirma que as emissões efetivas de hidrofluorcarbonos, perfluorcarbonos e hexafluoreto de enxofre devem ser estimadas, quando houver dados disponíveis, e utilizadas na preparação dos relatórios de emissões. As Partes devem esforçar-se ao máximo para desenvolver as fontes de dados necessárias;

3. Reafirma que os potenciais de aquecimento global utilizados pelas Partes devem ser os fornecidos pelo Painel Intergovernamental sobre Mudança do Clima em seu Segundo Relatório de Avaliação ("1995 IPCC GWP values" - valores do potencial de aquecimento global estabelecidos em 1995 pelo IPCC) com base nos efeitos dos gases de efeito estufa considerados em um horizonte de 100 anos, levando em conta as incertezas inerentes e complexas envolvidas nas estimativas dos potenciais de aquecimento global. Além disso, apenas a título de informação, as Partes também podem fazer uso de um outro horizonte de tempo, como estipulado no Segundo Relatório de Avaliação;

4. Lembra que, de acordo com a versão revisada de 1996 das Diretrizes para Inventários Nacionais de Gases de Efeito Estufa do Painel Intergovernamental sobre Mudança do Clima, as emissões baseadas em combustível vendido a navios ou aeronaves do transporte internacional não devem ser incluídas nos totais nacionais, mas relatadas separadamente; e incita o Órgão Subsidiário de Assessoramento Científico e Tecnológico a definir melhor a inclusão dessas emissões nos inventários gerais de gases de efeito estufa das Partes;

5. Decide que as emissões resultantes de operações multilaterais conforme a Carta das Nações Unidas não devem ser incluídas nos totais nacionais, mas relatadas separadamente; outras emissões relacionadas a operações devem ser incluídas nos totaisnacionais das emissões de uma ou mais Partes envolvidas.

\footnotetext{
${ }^{1}$ FCCC/SBSTA/1996/20, paras. 30 e 54.
} 

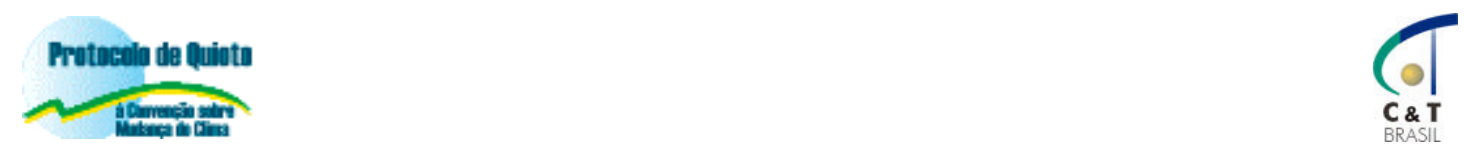

Decisão 3/CP.3

Implementação do Artigo 4, parágrafos 8 e 9, da Convenção

\section{A Conferência das Partes,}

Observando as disposições do Artigo 4, parágrafos 8 e 9, da Convenção-Quadro das Nações Unidas sobre Mudança do Clima,

Observando ainda as disposições do Artigo 3 da Convenção e do "Mandato de Berlim" em seu parágrafo $1(\mathrm{~b}){ }^{1}$

1. Solicita ao Órgão Subsidiário de Implementação, em sua oitava sessão, que inicie um processo de identificação e determinação de ações necessárias para suprir as necessidades específicas das Partes países em desenvolvimento, especificadas no Artigo 4, parágrafos 8 e 9, da Convenção, resultantes de efeitos adversos da mudança do clima e/ou do efeito da implementação de medidas de resposta. As questões a serem consideradas devem incluir ações relacionadas com a obtenção de fundos, seguro e transferência de tecnologia;

2. Solicita ainda ao Órgão Subsidiário de Implementação que informe à Conferência das Partes, em sua quarta sessão, os resultados desse processo;

3. Convida a Conferência das Partes, em sua quarta sessão, a tomar uma decisão sobre ações com base nas conclusões e recomendações desse processo.

\footnotetext{
${ }^{1}$ Decisão 1/CP.1.
} 


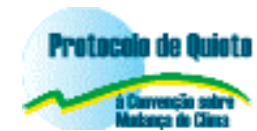

\section{RELATÓRIO DA CONFERÊNCIA DAS PARTES EM SUA TERCEIRA SESSÃO}

Tabela: Total das emissões de dióxido de carbono das Partes do Anexo I em 1990, para os fins do Artigo 25 do Protocolo de Quioto ${ }^{a}$

\section{Parte}

Alemanha

Austrália

Áustria

Bélgica

Bulgária

Canadá

Dinamarca

Eslováquia

Espanha

Estados Unidos da América

Estônia

Federação Russa

Finlândia

França

Grécia

Hungria

Irlanda

Islândia

Itália

Japão

Letônia

Liechtenstein

Luxemburgo

Mônaco

Noruega

Nova Zelândia

Países Baixos

Polônia

Portugual

Reino Unido da Grã-Bretanha

e Irlanda do Norte

República Checa

Romênia

Suécia

Suíça

Total
Emissões (Gg)

1.012 .443

288.965

59.200

113.405

82.990

457.441

52.100

58.278

260.654

4.957 .022

37.797

2.388 .720

53.900

366.536

82.100

71.673

30.719

2.172

428.941

1.173 .360

22.976

208

11.343

71

35.533

25.530

167.600

414.930

42.148

584.078

169.514

171.103

61.256

43.600
Porcentagem

7,4

2,1

0,4

0,8

0,6

3,3

0,4

0,4

1,9

36,1

0,3

17,4

0,4

2,7

0,6

0,5

0,2

0,0

3,1

8,5

0,2

0,0

0,1

0,0

0,3

0,2

1,2

3,0

0,3

4,3

1,2

1,2

0,4

0,3

100,0

\footnotetext{
${ }^{a}$ Dados baseados em informações recebidas das 34 Partes do Anexo I que submeteram suas primeiras comunicações nacionais em 11 de dezembro de 1997 ou antes dessa data, compiladas pelo Secretariado em vários documentos (A/AC.237/81; FCCC/CP/1996/12/Add.2 e FCCC/SB/1997/6). Algumas das comunicações continham dados sobre as emissões de $\mathrm{CO} 2$ por fontes e remoções por sumidouros resultantes de mudança no uso da terra e florestas, porém esses dados não foram incluídos porque as informações foram relatadas de diferentes modos.
} 


\section{:: Anexo II - Endereços (URLs) das imagens impressas ::}

Obs.: Todas as imagens foram acessadas pelo menos uma vez, desde agosto de 2005, mas assinalamos, aqui, a data do último acesso que confirmou a permanência das imagens nas referidas URLs.

\section{:: Série Tubos ::}

\section{Figura 1}

Disponivel em: http://english.pravda.ru/img/2005/07/kyoto_protocol.jpg

e http://climatechange.sea.ca/smoke_stack.jpg

e http://www.oneclimate.net/imagelib/posts/20070427/is2p2.jpg

Acesso em: 15 Abr. 2008

\section{Figura 2}

Disponivel em: http://media.canada.com/b17a5268-e809-4db2-a84b-

06fc4c00d03e/M1X00056_carbontax.JPG?size $=$ hh1

Acesso em: 15 Abr. 2008

\section{Figura 3}

Disponivel em: http://www.greendiary.com/images/kyoto_protocol_can_be_met.jpg Acesso em: 15 Abr. 2008

\section{Figura 4}

Disponivel em: http://www.theepochtimes.com/news images/2005-2-18-greenhouse.jpg Acesso em: 15 Abr. 2008

\section{Figura 5}

http://www.cinu.org.mx/prensa/fotos/polucion.jpg

Acesso em: 15 Abr. 2008

\section{Figura 6}

Disponivel em: http://www.chinadaily.net/english/doc/2004-

10/23/xin_061001230900500200958.jpg

Acesso em: 15 Abr. 2008

\section{Figura 7}

Disponivel em: http://lakes.chebucto.org/VIEW/ICON/smokestacks.jpg

Acesso em: 15 Abr. 2008

\section{Figura 8}

http://www.abc.net.au/reslib/200312/r12991_31259.jpg

Acesso em: 15 Abr. 2008

\section{Figura 9}

http://www.republicanvoices.org/power_plants.jpg

Acesso em: 15 Abr. 2008 


\section{Figura 10}

http://www.duitslandweb.nl/binaries/Thema/Verkiezingen_2005/verkiezingsthemas/kerncent rale_194.jpg

Acesso em: 15 Abr. 2008

\section{:: Série Branca ::}

\section{Figura 1}

Disponivel em: http://bellaciao.org/es/IMG/gif/glaciar.gif

Acesso em: 15 Abr. 2008

\section{Figura 2}

Disponivel em: http://www.foei.org/climate/images/2004-11 everest4.jpg

Acesso em: 15 Abr. 2008

\section{Figura 3}

Disponivel em: http://pubs.acs.org/cen/images/8242/8242gov2 moulin.JPG

Acesso em: 15 Abr. 2008

\section{Figura 4}

Disponivel em: http://www.zeenews.com/images/Australia warming News.jpg

Acesso em: 15 Abr. 2008

\section{Figura 5}

Disponivel em:

http://www.utmsi.utexas.edu/staff/dunton/gk12/islandtoice/The\%20Greenhouse\%20Effect \%20and\%20Global\%20Warming internet\%20version files/slide0001 image003.jpg

Acesso em: 15 Abr. 2008

\section{Figura 6}

Disponivel em: http://www.abc.net.au/reslib/200602/r71813 200001.jpg

Acesso em: 15 Abr. 2008

\section{Figura 7}

Disponivel em: http://www.instablogsimages.com/images/2007/11/28/melting-

glaciers 7548.jpg

Acesso em: 15 Abr. 2008

\section{Figura 8}

Disponivel em: http://www.undispatch.com/pola\%20bears.jpg

Acesso em: 15 Abr. 2008

\section{Figura 9}

Disponivel em: http://oglobo.globo.com/fotos/2007/04/06/06_MHG_glacial.jpg Acesso em: 15 Abr. 2008 
:: Série Girassóis ::

\section{Figura 1}

Disponivel em: http://www.windenergy.org.nz/images/teapiti.jpg

Acesso em: 15 Abr. 2008

\section{Figura 2}

Disponivel em: http://www.airtricity.com/ internal/cimg!0/jg13ykfcm5r

Acesso em: 15 Abr. 2008

\section{Figura 3}

Disponivel em: http://www.coolstoke.co.uk/news/images/news/18 1.jpg

Acesso em: 15 Abr. 2008

\section{Figura 4}

Disponivel em: http://www.windenergy.org.nz/photos/haunui/874windmj.jpg Acesso em: 15 Abr. 2008

\section{Figura 5}

Disponivel em: http://www.trustpower.co.nz/Content/images/windfarm.jpg Acesso em: 15 Abr. 2008

\section{Figura 6}

Disponivel em: http://www.sutton.gov.uk/NR/rdonlyres/BE6BC4D7-96F2-429A-8E793FD3E28AEEEB/0/whatisbeingdonenationally1.jpg

Acesso em: 15 Abr. 2008

\section{Figura 7}

Disponivel em: http://palazzo.pro.br/fotos/DSC06276.JPG

Acesso em: 15 Abr. 2008

\section{Figura 8}

Disponivel em:

http://www.climateforchange.ca/files/climateforchange.ca/imce images/HomePageGraphicbackground.jpg

Acesso em: 15 Abr. 2008

\section{Figura 9}

Disponivel em:

http://www.emersonprocess.com/home/news/resources/images/npower windfarm hires.jpg Acesso em: 15 Abr. 2008 


\section{:: Imagens-sensação ::}

\section{Figura 1}

Disponivel em: http://www.enerconindia.net/images/thermalpollution.jpg Acesso em: 15 Abr. 2008

\section{Figura 2}

Disponivel em: http://www.economist.com/images/ga/2005w06/Climate.jpg Acesso em: 15 Abr. 2008

\section{Figura 3}

Disponivel em:

http://www.smh.com.au/ffximage/2005/02/16/climatechange wideweb 430x323.jpg e http://www.education.theage.com.au/userimages/issu101104.jpg Acesso em: 15 Abr. 2008

\section{Figura 4}

Disponivel em: http://guajirodreams.com/blogs/images/ (PolarBear.jpg)

Acesso em: 15 Abr. 2008

\section{Figura 5}

http://www.sfgate.com/c/pictures/2007/08/19/mn spencer tunick ale107.jpg Acesso em: 15 Abr. 2008

\section{Figura 6}

http://www.windenergy.org.nz/photos/gallery/tararua2/040727-NZ-TararuaB\&WMist.jpg Acesso em: 15 Abr. 2008

\section{Figura 7}

Disponivel em: http://www.windenergy.org.nz/photos/gallery/overseas/020322-NorwayN43Winter.jpg

Acesso em: 15 Abr. 2008 


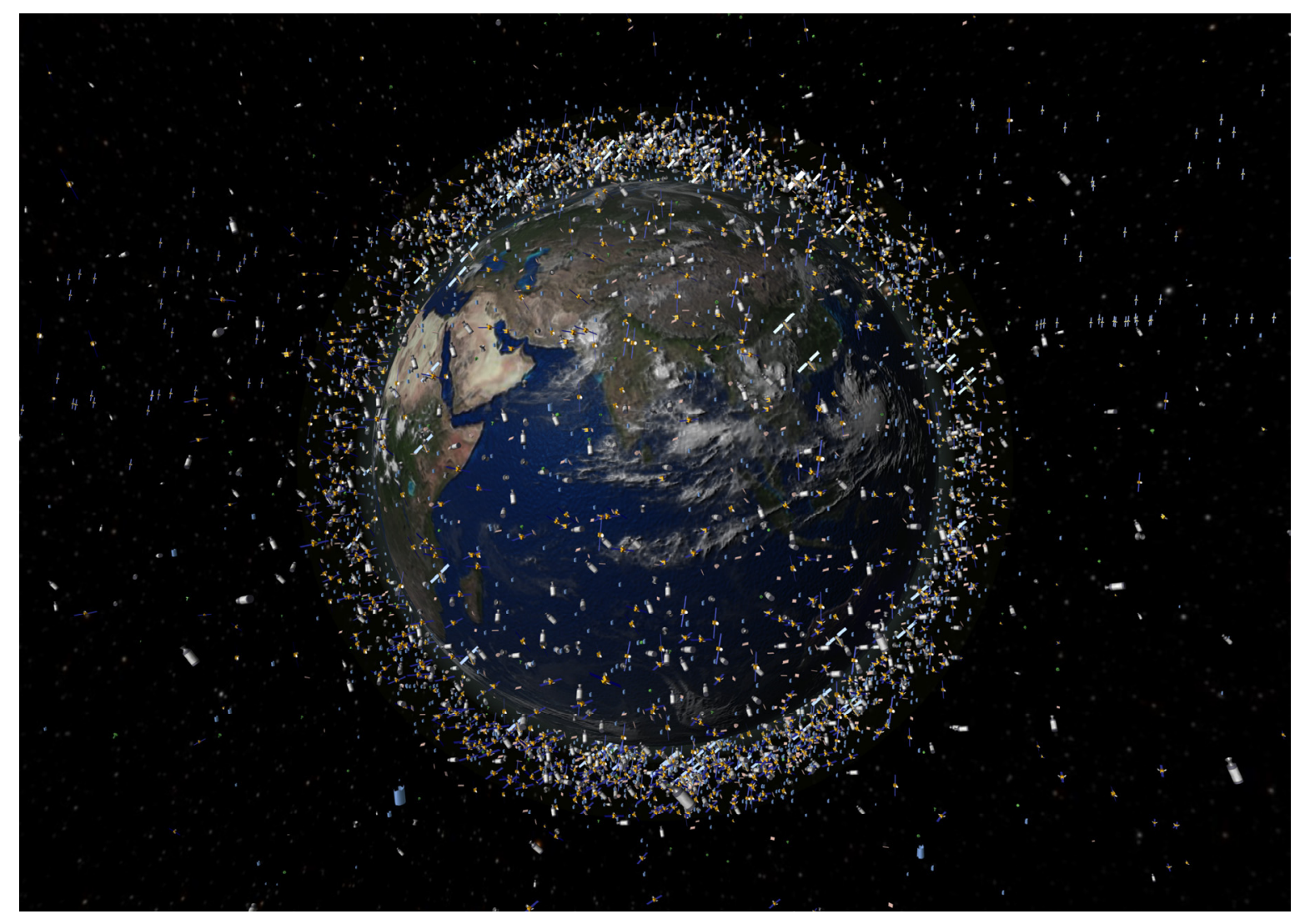




\section{Legenda:}

Trackable objects in orbit around Earth/ Objects in Low Earth Orbit (LEO) - view over the equator.

\section{Descrição:}

The launch of the first artificial satellite by the Soviet Union in 1957 marked the beginning of the utilization of space for science and commercial activity. During the Cold War, space was a prime area of competition between the USSR and USA, reaching its climax with the race to the Moon in the 1960s. In, 1964 the first TV satellite was launched into a geostationary orbit in order to transmit the Olympic games from Tokyo. Later, Russian launch activities declined while other nations set up their own space programs. Thus, the number of objects in Earth orbit has increased steadily - by two hundred per year on average.

The geostationary ring is at an altitude of about $36000 \mathrm{~km}$. This orbit is heavily used by telecommunication satellites. Eighty percent of all catalogued objects are in low-Earth orbit (LEO), which extends to $2000 \mathrm{~km}$ above the Earth's surface. To observe the Earth, spacecraft must orbit at such a low altitude. The spatial density of objects increases at high latitudes. ${ }^{1}$

\footnotetext{
${ }^{1}$ Disponível em: http://www.esa.int/esa$\mathrm{mmg} / \mathrm{mmg} . \mathrm{pl}$ ? $\mathrm{b}=\mathrm{b} \&$ type $=\mathrm{I} \&$ collection $=$ Spacecraft\%20Operations\&single $=\mathrm{y} \& \mathrm{start}=2 \&$ size $=\mathrm{b}$ e http://esamultimedia.esa.int/images/spacecraft-operations/space_debris/Bee-Hive-3_H1.jpg Acesso em: 21 Abr. 2008. Foto: ESA (European Space Agency)
} 